Carolina Dzimidas Haber

\title{
A RELAÇÃO ENTRE O DIREITO E A POLÍTICA NO PROCESSO LEGISLATIVO PENAL
}

\author{
Tese de Doutorado \\ Área de concentração: Filosofia e \\ Teoria Geral do Direito \\ Orientador: Prof. Titular José Eduardo \\ Campos de Oliveira Faria
}

Faculdade de Direito da Universidade de São Paulo São Paulo, 2011 


\section{AGRADECIMENTOS}

Essa tese, sem dúvidas, não é um trabalho que se desenvolveu apenas dentro da biblioteca. Ela é fruto não só de muita pesquisa, mas de tudo o que aprendi trabalhando no governo federal, oportunidade que abriu meus olhos para a distância entre o direito ensinado nas faculdades e aquele com o qual precisamos lidar na prática, em busca de uma solução, que nem sempre é a ideal, mas é a possível em meio à diversidade de opiniões.

Sendo assim, não poderia deixar de agradecer a todos os funcionários da Secretaria de Assuntos Legislativos do Ministério da Justiça, e, especialmente, ao Pedro Vieira Abramovay, pelo apoio, incentivo e amizade, que fizeram desse lugar um dos mais incríveis onde já trabalhei. Obrigada também pela paciência durante minhas ausências em razão dos compromissos relacionados ao doutorado.

À Subchefia de Assuntos Jurídicos da Casa Civil, agradeço em nome do Beto Vasconcelos, por ter acreditado que, na fase mais difícil, de elaboração da tese, eu conseguiria cumprir os compromissos do trabalho.

Agradeço o professor e orientador José Eduardo Campos de Oliveira Faria, pela sua visão sobre o direito, que sempre me instigou, e por acreditar e confiar em mim, desde a época em que fui bolsista do programa PET-Sesu/MEC da Faculdade de Direito da Universidade de São Paulo.

Agradeço os professores Jean Paul Cabral Veiga da Rocha, Pierpaolo Cruz Bottini e Maíra Rocha Machado, não só pelas sugestões valiosas durante a banca de qualificação (e fora dela), mas por terem sido, desde quando os conheci, na graduação, exemplos a seguir.

Agradeço os amigos do programa PET-Sesu/MEC da Faculdade de Direito da Universidade de São Paulo, por continuarem presentes na minha vida e sempre me incentivarem a acreditar na nossa vocação acadêmica.

Agradeço os amigos que sempre me apoiaram e, em especial, os que leram esse trabalho e contribuíram com sugestões, Luiz Guilherme Paiva, Felipe de Paula, Mariana 
Levy, Melissa Mestriner e Daniel Arbix, com os quais eu compartilhei, nesses anos em Brasília, a esperança de construir um país melhor.

À minha querida família, que cresceu nesses últimos anos. Aos novos membros, agradeço em nome do Caco e da Yvonne, por terem me recebido com tanto carinho.

Por fim, porque nem saberia como agradecer, dedico esse trabalho ao Pedro, por me transformar, a cada dia, numa pessoa melhor. Obrigada por tornar tudo tão leve, inclusive o nosso futuro. 


\section{SUMÁRIO}

Resumo

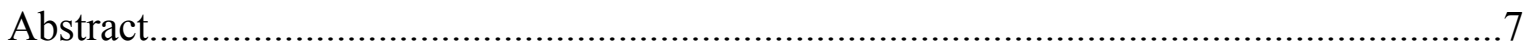

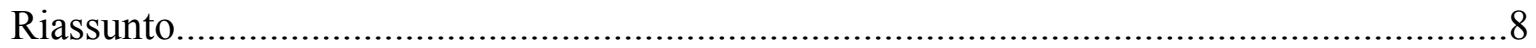

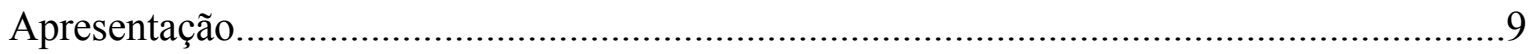

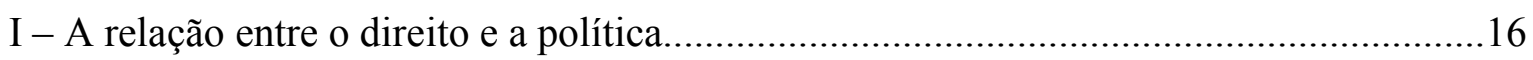

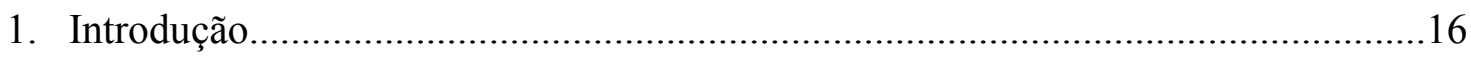

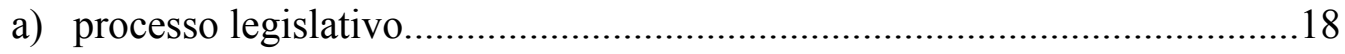

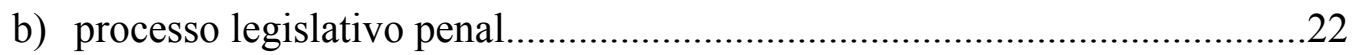

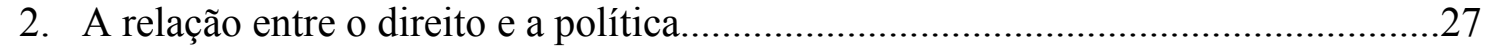

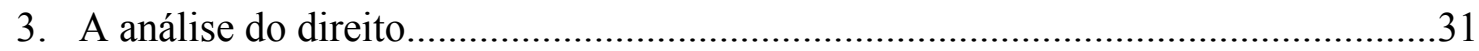

a) o princípio da racionalidade do legislador...................................................38

b) o princípio da soberania do legislador.........................................................40

4. Positivismo jurídico e processo legislativo................................................................42

5. A relação entre direito penal e política criminal.......................................................4

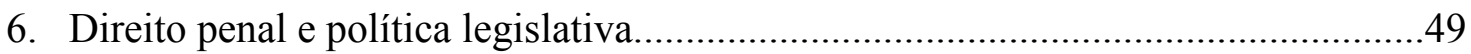

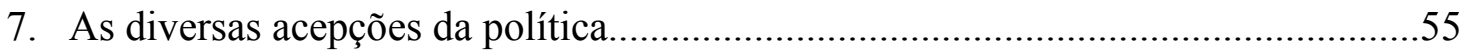

8. Proposta de reformulação do papel da dogmática jurídica...........................................57

II - As transformações do direito e os reflexos no processo legislativo.................................62

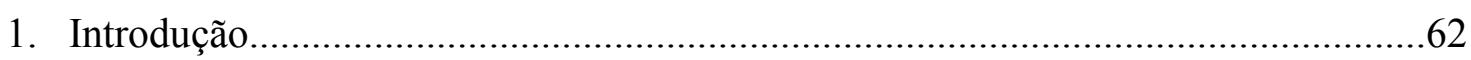

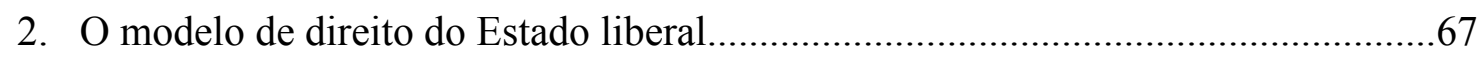

3. O modelo de direito do Estado intervencionista.....................................................72

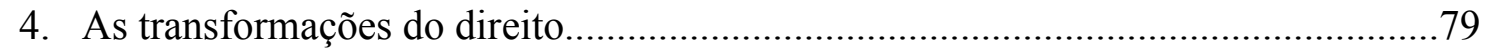

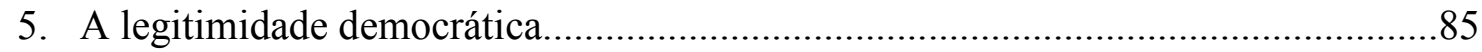

6. O Poder Legislativo como um espaço de deliberação democrática............................91

7. Proposta de reformulação do direito penal.................................................................97

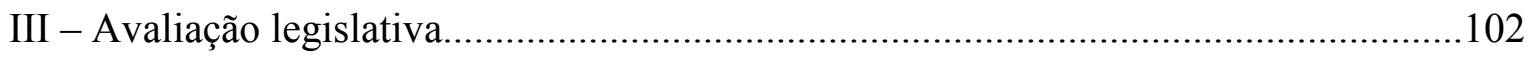

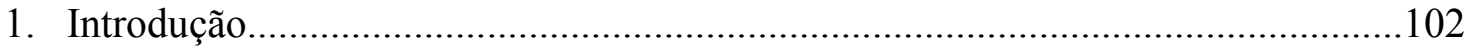

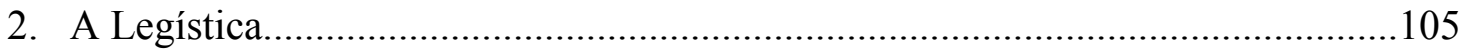

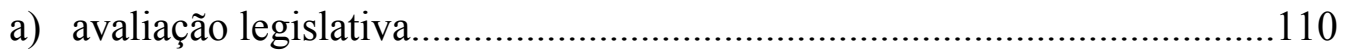

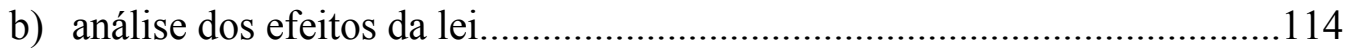

c) programas de avaliação legislativa...........................................................118 
d) dificuldades relacionadas à avaliação....................................................122

e) fundamentação constitucional da avaliação legislativa.............................127

f) avaliação legislativa e o direito..........................................................128

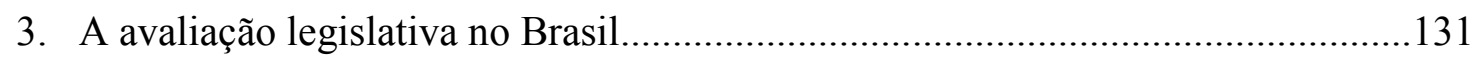

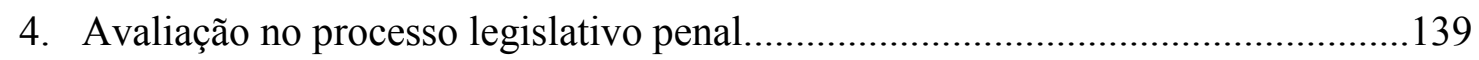

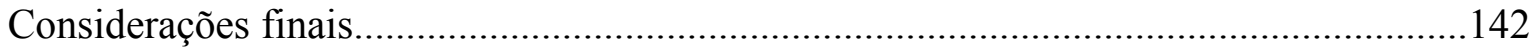

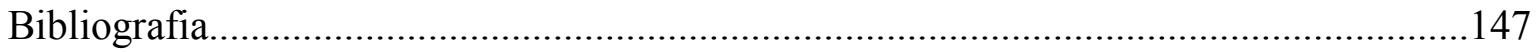

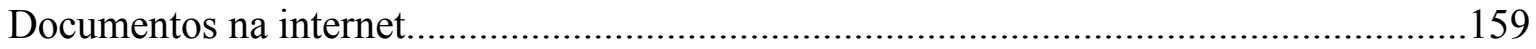




\section{RESUMO}

O objetivo desse trabalho é rever o papel da dogmática jurídica no processo legislativo, diante da constatação de que sua análise volta-se ao estudo da norma após seu ingresso no ordenamento jurídico, ao invés de ser realizada na fase de sua formulação, na medida em que se trata de um espaço mais suscetível à participação e ao debate democrático.

Além de propor que o processo legislativo seja concebido como um espaço de diálogo entre os diversos interessados nos temas em discussão, mediante a apresentação de argumentos e não apenas de meras opiniões, sugere-se que a formulação do direito seja concebida como uma política pública, tornando-se necessário analisar previamente o impacto das leis e avaliar seus efeitos após a sua promulgação.

No âmbito específico do direito penal, tratando-se, do ponto de vista das garantias constitucionais, da última esfera de intervenção estatal, a proposta do trabalho é assegurar que sua formulação ocorra mediante a verificação do problema que se quer combater, dos instrumentos à disposição e dos efeitos que o meio escolhido pode ocasionar, evitando-se, assim, a adoção de medidas populistas, que deveriam, além disso, se submeter a testes argumentativos antes de serem aprovadas. 


\begin{abstract}
The purpose of this work is the review the role of the legal dogmatic at the legislative process, in face of the verification that its analysis is directed to the study of the rule after being effective as a legal ruling, instead of performing it at the preparation stage, to the extent in which it is an area more subject to the participation and democratic discussion.
\end{abstract}

Besides proposing that the legislative process is conceived as a area for discussion between the several parties interested at the matters in question, upon the presentation of arguments and not only simple opinions, it is suggested that the preparation of law itself is conceived as a public policy, being necessary the previous analysis of the impact of laws and evaluate its effects after they becoming effective.

At the specific scope of the criminal law, discussing, from the point of view of the constitutional guarantees, the last sphere of state intervention, the purpose of the work is to ensure that its preparation takes place upon the verification of the problem intended to be solved, the instruments available and the effects that the mean chosen may cause, thus, avoiding the adoption of popular measures, that should, in addition, be submitted to argument trials before being approved. 


\section{RIASSUNTO}

Lo scopo di questo lavoro è quello di rivedere il ruolo della dogmatica giuridica nel processo legislativo, considerato il fatto che la sua analisi torna allo studio della norma dopo la sua entrata nel sistema giuridico, invece di essere posseduto nella sua fase di formulazione, in quanto che questo è un settore più suscettibile alla partecipazione $\mathrm{e}$ al dibattito democratico.

Oltre a proporre che il processo legislativo sia progettato come un forum per il dialogo tra le varie parti interessate sui temi in discussione con la presentazione di argomenti e non solo semplici opinioni, si suggerisce che la formulazione della legge sia concepita come una politica pubblica rendendo necessario esaminare in primo luogo l'impatto delle leggi e valutare i loro effetti dopo la promulgazione.

Nel contesto specifico del diritto penale, dal punto di vista delle garanzie costituzionali, del'ultima sfera di intervento dello Stato, il lavoro proposto è di garantire che la sua formulazione è avvenuta verificando il problema che ci vuole combattere, degli strumenti disponibili e gli effetti che i mezzi scelti possono causare, evitando in tal modo l'adozione di misure populiste, che dovrebbe anche sottoporsi a test argomentativi prima di essere approvato. 


\section{APRESENTAÇÃO}

O presente trabalho surge de uma inquietação sobre a postura dos juristas diante do processo de elaboração das normas jurídicas. É comum verificar, por exemplo, ao analisar os programas das faculdades de direito, apenas a preocupação com o ensino da forma como o processo legislativo é regulamentado pela Constituição Federal, reproduzindo-se as regras ali previstas sobre iniciativa, quorum de aprovação de projetos de lei e propostas de emenda à Constituição, sanção e veto.

A tendência, portanto, é ignorar qualquer outra questão que diga respeito ao conteúdo do que é discutido no Parlamento, voltando-se o foco de atenção para as normas que já ingressaram no ordenamento jurídico.

Nesse sentido, torna-se mais importante a discussão sobre como compatibilizar o conteúdo da norma com o restante do ordenamento em que ela se insere, após a sua promulgação, além do desenvolvimento de técnicas de interpretação dessa norma que viabilizem a sua aplicação no caso concreto, do que analisar os problemas que seu conteúdo pode causar antes de seu ingresso definitivo no ordenamento jurídico.

Diante dessa realidade, a proposta é, a partir de um enfoque multidisciplinar, rever o papel da dogmática no processo de elaboração de proposições legislativas. Com o intuito de realizar essa tarefa, sugere-se uma mudança do foco de análise da norma vigente, na medida em que o limite de atuação é o direito positivo, para o estudo da norma em processo de formulação, como um espaço mais suscetível a influências externas e mais propício à apresentação de argumentos a favor ou contra o texto a ser votado no Parlamento.

O enfoque está, portanto, voltado ao momento em que uma proposição legislativa é convertida em norma jurídica por meio de uma decisão política, bem como às implicações que surgem antes e depois desse momento. 
Nesse sentido, importa verificar como o direito e a política se relacionam, inclusive, para compreender as possíveis razões que levaram a ciência jurídica a negligenciar o estudo do processo de elaboração de normas.

A princípio, é possível destacar duas consequências desse distanciamento. Em primeiro lugar, o jurista não enxerga esse momento como um espaço de atuação e de diálogo. No limite, o resultado é a própria ineficiência do direito, que continua se desenvolvendo teoricamente sem exercer nenhuma influência na sua elaboração, cada vez mais acelerada diante das transformações sociais, provocando uma proliferação de normas sem preocupação com critérios como a coerência ou, o que é mais grave, sua aplicabilidade.

Em segundo lugar, o processo de elaboração normativa não é visto como uma política pública. Se a aplicação das normas produz efeitos sociais, políticos e econômicos, todos os seus efeitos devem ser medidos, avaliados e ponderados.

Não basta, portanto, que o jurista reconheça seu espaço no processo legislativo, é preciso que os políticos formulem as normas mediante a compreensão de que, na maioria das vezes, estão fazendo uma política pública, a qual deve ser analisada previamente, revista e avaliada.

Essas duas questões relacionam-se com outra, que se traduz como a segunda inquietação que permeia esse trabalho. Dizer que o jurista deve conceber o processo legislativo como um espaço de atuação e a tarefa de elaboração de leis deve ser permeada pela lógica das políticas públicas é afirmar que existem canais de participação na discussão e formulação de atos normativos que vão além da vontade expressa nas urnas.

Em última instância, pensar o processo legislativo para além do exercício da representatividade política significa ampliar o conceito de democracia. Especificamente em relação ao direito, essa percepção permite que o jurista se reconheça como um ator do debate político e da construção de políticas públicas, abandonando, assim, sua postura tradicional de isolamento.

A premissa que permeia esse trabalho é, portanto, a crença na capacidade do diálogo e da troca de informações para o fortalecimento da democracia. Diante de posturas de descrença na tarefa de elaboração de atos normativos, conferida ao Parlamento, que no 
direito se reflete na importância atribuída à atividade dos outros poderes, pretende-se resgatar esse espaço como um lugar de participação e construção de políticas públicas.

Com relação ao papel do jurista no processo legislativo, a intenção é propor uma reformulação dos modelos teóricos prevalecentes entre os juristas, "baseados na ênfase à unidade entre Estado e direito positivo e no levantamento sistemático da legislação, da jurisprudência e da doutrina predominante nos tribunais" ${ }^{1}$.

Esses modelos teóricos, que, segundo José Eduardo Faria, "são construções lógicas desenvolvidas para dar conta, analiticamente, de problemas, questões e conjunturas específicas", precisam "de reformas, ajustamentos, adaptações, complementações e cortes que mantenham sua validade explicativa e seu rigor analítico"; entretanto, conforme afirma o autor, "em nossos meios jurídicos, como é sabido, ainda predomina uma cultura essencialmente formalista que (a) insiste em associar o direito a um sistema fechado e racional de normas produzido por um legislador idealizado e (b) não costuma indagar se os sujeitos de direito cumprem ou não as normas, o motivo pelo qual o fazem e, menos ainda, se dessa conduta resultam efeitos desejados sobre a realidade" ${ }^{2}$.

Considerando as peculiaridades de cada um dos diversos ramos do direito, a análise se restringe ao penal ${ }^{3}$, especialmente em razão de algumas especificidades que envolvem o processo legislativo sobre esse tema, relacionadas, principalmente, com questões importantes para a sociedade, como a violência e a criminalidade.

Os deputados e senadores, responsáveis pela elaboração e tramitação de proposições legislativas que regulamentam o direito penal, costumam traduzir os conflitos sociais que envolvem atos violentos ou lesões a bens considerados relevantes para a sociedade mediante a criminalização de novas condutas e o endurecimento do tratamento das já existentes, como forma de responder aos sentimentos de insegurança e de vingança social.

Nesse sentido, acabam refletindo o imaginário popular, centrado no controle repressivo-penal do crime, em detrimento de uma abordagem interdisciplinar do tema,

\footnotetext{
${ }^{1}$ José Eduardo Campos de Oliveira Faria. Sociologia: Direito e conjuntura. São Paulo: Saraiva, 2010, p. 116-117.

${ }^{2}$ José Eduardo Campos de Oliveira Faria. Sociologia..., p. 116-117.

${ }^{3}$ Sobre a esfera de abrangência desse termo, ver o primeiro capítulo.
} 
acompanhado de um discurso pela valorização da prevenção associada genericamente à adoção de políticas públicas de desenvolvimento econômico e inclusão social, propagada por estudiosos do tema.

Mais especificamente com relação aos juristas, é comum que a aprovação de proposições legislativas em matéria penal seja recebida com muitas críticas, especialmente por se mostrar dissonante às garantias constitucionais de proteção do indivíduo ou incoerentes com as demais regras do ordenamento jurídico, que preconizam um sistema gradativo e equilibrado de condutas e sanções.

O diálogo entre estudiosos do tema, como os juristas, e os políticos, praticamente não existe e as proposições legislativas seguem sendo aprovadas sem que se considerem suas consequências tanto em relação ao próprio ordenamento, quanto seus reflexos externos, enquanto medidas capazes de corresponder aos anseios sociais e diminuir a criminalidade e a violência.

É no direito penal que se verifica uma maior possibilidade de alterações legislativas em razão de comoções públicas, que instigam o legislador a atuar sem considerar as diretrizes político-criminais que deveriam influenciar a escolha dos comportamentos a ser ou não criminalizados ou das condutas que poderiam ter suas sanções agravadas ou procedimentos de investigação modificados.

Verifica-se, portanto, que a prática está totalmente dissociada da produção teórica sobre o tema. Enquanto estudiosos desenvolvem pesquisas sobre formas de prevenir o crime, apresentam dados aptos a identificar os melhores instrumentos e áreas de atuação para combater a criminalidade, os legisladores seguem adotando medidas repressivas sem qualquer demonstração da sua capacidade de resolver, de fato, o problema.

É nesse sentido que a elaboração de normas penais deve ser concebida como uma política pública, na medida em que se torna necessário esclarecer qual o problema que se quer evitar, os instrumentos à disposição para combatê-lo e os efeitos que o meio escolhido é capaz de ocasionar.

Com o intuito de observar essas questões a tese foi dividida em três capítulos. No primeiro, pretende-se analisar os motivos que levaram a ciência jurídica a negligenciar o estudo do processo de elaboração de atos normativos. 
A partir do pressuposto de que o processo legislativo consubstancia-se como um ponto de encontro entre o direito e a política, a compreensão desse fenômeno foi realizada a partir da forma como se deu a relação entre essas duas ciências, que se tornaram ainda mais distantes com o advento da corrente positivista de análise do direito.

De fato, alguns dogmas do positivismo jurídico, como o pressuposto de racionalidade do legislador, e a adoção de um formalismo exacerbado por algumas correntes dessa escola de pensamento, impediram que a ciência do direito se desenvolvesse desconectada da dogmática jurídica, e, consequentemente, pudesse voltar sua análise à fase de formulação das normas jurídicas.

A partir dessa constatação, não se pretende questionar a importância do positivismo jurídico para a análise do direito, mas identificar em que medida é possível rever essa postura de distanciamento do processo legislativo, permitindo, assim, que os juristas reconheçam nesse processo um espaço de atuação.

Um dos fatores que favorecem essa proposta de reposicionamento do papel da doutrina jurídica são as mudanças vivenciadas pelo direito, que deixa de ser visto como um sistema fechado, unitário, hierárquico, e passa a sofrer a influência de fatores políticos, econômicos e sociais.

Essas mudanças serão analisadas no segundo capítulo. A proposta é verificar como as transformações vivenciadas pela sociedade contemporânea modificaram o direito, a partir do pressuposto de que há uma relação entre o direito e a política capaz de marcar profundamente a concepção do direito que se quer estabelecer em determinada forma de Estado.

Essa análise permite compreender como as mudanças no papel do Estado influenciam a forma como o direito é concebido, possibilitando sua associação à tarefa de construção e implementação de políticas públicas, inclusive como forma de conter a proliferação anárquica de normas, oriunda da transformação cada vez mais acelerada da sociedade.

Além de observar determinados fins e objetivos, submetendo-se à análise de impacto e avaliação dos efeitos de sua produção normativa, o processo legislativo deve ser 
compreendido como um espaço de diálogo entre os diversos atores interessados nos temas em discussão, entre os quais, encontram-se os juristas.

Nesse sentido, mediante a possibilidade de participação dos interessados no processo legislativo, amplia-se a noção de democracia para além da representatividade, reconhecendo-se no Parlamento um espaço de apresentação de argumentos e de debate aberto a todos.

No âmbito do direito penal, é preciso dizer que não se trata de uma discussão fundamentada em receios e anseios populares. Não basta ouvir, portanto, a sociedade, diante de desejos de vingança em face de acontecimentos violentos. Ampliar a democracia não é dar ensejo ao populismo penal, mas ouvir todos os argumentos, que podem, e devem, ser testados diante, inclusive, das garantias constitucionais, que não podem ser ignoradas.

É possível afirmar que o trabalho dialoga com dois conflitos. De um lado, entre o conhecimento técnico, mais especificamente, jurídico, e a política. A forma proposta para lidar com esse conflito é o diálogo, desde que não consista na mera apresentação de opiniões, mas no debate acerca de argumentos.

De outro lado, entre a forma e o conteúdo das leis. Para lidar com a perda de coerência, consistência e clareza das leis, oriunda da sua proliferação desenfreada, não basta apenas propor melhorias em sua elaboração formal, é preciso desenvolver uma técnica de aperfeiçoamento qualitativo de sua estrutura, questionando seus efeitos concretos, o grau de aplicação de seus dispositivos e os resultados que permite alcançar.

É preciso, portanto, compreender o processo legislativo como um espaço de aproximação das normas jurídicas com a realidade, instituindo-se mecanismos de avaliação e de análise do impacto das leis.

Trata-se de abandonar a premissa de que as leis precisam apenas ser elaboradas de acordo com um formato determinado e mediante a observância de regras procedimentais, admitindo-se que é preciso avaliar seus efeitos e seu impacto sobre a sociedade, para, no limite, assegurar sua capacidade de resolver os problemas concretos. 
Essa é a proposta do terceiro capítulo, que, além de se dedicar às experiências internacionais sobre avaliação legislativa, procura compreender qual a situação dessa discussão no Brasil, destacando sua importância no processo legislativo penal. 


\section{I - A RELAÇÃo ENTRE O DIREITO E A POLÍTICA}

\section{Introdução}

Como todo objeto de estudo, as normas jurídicas podem ser examinadas de diferentes maneiras, de acordo com o ponto de vista do observador.

Tratando-se especificamente do processo de elaboração dessas normas, é possível identificar, por exemplo, a compreensão desse objeto pela ciência política, que geralmente analisa a forma como se dá a relação entre os partidos políticos e entre os poderes Executivo e Legislativo mediante a edição de medidas provisórias, como os interesses em jogo influenciam o processo de decisão no Parlamento e em que medida as normas criadas são produtos de relações de força e de questões de poder ${ }^{4}$.

De outro lado, para a ciência jurídica ${ }^{5}$, o estudo desse objeto volta-se, muitas vezes, à definição e sistematização das regras que regulamentam o processo legislativo, do ponto de vista formal ${ }^{6}$.

Em geral, a análise jurídica desse processo consiste no exame da regulamentação constitucional da sucessão de atos realizados para aprovação de leis em

\footnotetext{
${ }^{4}$ No Brasil, é o caso das pesquisas que vem sendo realizadas por autores como Fernando Limongi, Argelina Figueiredo e Fabiano Santos, dentre os quais, os seguintes: Argelina Cheibub Figueiredo e Fernando Limongi. Política orçamentária no presidencialismo de coalizão. Rio de Janeiro: FGV, 2008 e Fabiano Guilherme Mendes Santos. O poder legislativo no presidencialismo de coalizão. Belo Horizonte: UFMG e Rio de Janeiro: IUPERJ, 2003.

${ }^{5}$ Apesar da análise crítica que será realizada mais adiante sobre a relação entre ciência jurídica e dogmática jurídica, utiliza-se o termo "ciência jurídica", nesse primeiro momento, para designar o conjunto de princípios e regras que tem por tarefa definir e sistematizar o ordenamento jurídico que o Estado impõe à sociedade e apontar a solução para os problemas ligados à sua interpretação e aplicação, isto é, admite-se que a ciência do direito identifica-se com a dogmática, pois o cientista do direito deve aceitar a regra jurídica como um dogma, para interpretá-la e aplicá-la na solução dos conflitos. Segundo Tércio Sampaio Ferraz Júnior, "os juristas, em termos de um estudo estrito do direito, procuram sempre compreendê-lo e torná-lo aplicável dentro dos marcos da ordem vigente. Esta ordem que lhes parece como um dado, que eles aceitam e não negam, é o ponto de partida inelutável de qualquer investigação. Ela constitui uma espécie de limitação, dentro da qual eles podem explorar as diferentes combinações para a determinação operacional de comportamentos juridicamente possíveis" (Introdução ao estudo do direito. $4^{\mathrm{a}}$ ed. São Paulo: Atlas, 2003 p. 48).

${ }^{6}$ Nesse sentido, podem ser citados os manuais de direito constitucional, que dedicam alguns capítulos ao estudo do processo legislativo, da forma como previsto na Constituição Federal, e alguns manuais de processo legislativo, dentre os quais os que foram elaborados por Manoel Gonçalves Ferreira Filho (Do processo legislativo. São Paulo: Saraiva, 2007) e José Afonso da Silva (Processo constitucional de formação de leis. $2^{\mathrm{a}}$ ed. $2^{\mathrm{a}}$ tir. São Paulo: Malheiros, 2007).
} 
geral, relativa a questões como iniciativa, quorum de aprovação, sanção e veto. Entretanto, mesmo o estudo dessas regras tem sido negligenciado pelos juristas, que, se demonstram pouco interesse pelas regras formais, menor atenção ainda conferem ao estudo desse processo do ponto de vista material ${ }^{7}$.

Pretende-se, nesse capítulo, analisar a forma como a ciência jurídica concebe o processo de elaboração de atos normativos no âmbito do Poder Legislativo. Não se trata de uma análise das regras constitucionais e demais disposições normativas que regulamentam o processo legislativo, isto é, das regras formais de tramitação e de aprovação de uma lei, mas do seu aspecto material.

Isso porque esse processo se realiza através de uma seqüência de atos complexos, que podem mudar de direção conforme a conjuntura, os atores que deles participam e os interesses em jogo, sendo que essa realidade se revela à margem das regras aplicáveis ao processo legislativo.

A ciência jurídica, entretanto, pressupõe a linearidade desse processo como se bastasse estabelecer regras formais para aprovação das leis, ignorando em sua análise a forma como funcionam, na prática, esses institutos previstos na legislação vigente. Partese, portanto, do estudo da norma após seu ingresso no ordenamento jurídico, independentemente da maneira como seu conteúdo foi elaborado.

É sob esse enfoque que se pretende analisar o processo legislativo, isto é, observar seus mecanismos reais de funcionamento, relacionando-o com as contribuições que a dogmática jurídica pode oferecer ao seu estudo.

Assim como a ciência política se propõe a observar o processo de análise e aprovação de uma proposição legislativa para além do exame dos debates parlamentares, considerando a participação dos envolvidos, os interesses em jogo, as reuniões informais realizadas entre os parlamentares e demais interessados, dentre outras questões, sugere-se que a ciência jurídica extrapole os limites da observação da norma posta, avaliando seu

\footnotetext{
${ }^{7}$ Apesar de ser possível encontrar alguns trabalhos recentes de juristas que buscam compreender o direito e a sua relação com o processo legislativo de forma substancial, ainda se trata de um universo muito reduzido. É o caso das seguintes teses de doutorado, disponíveis no banco de teses da Universidade de São Paulo (www.teses.usp.br, acesso em 10.08.2010), que foram apresentadas em 2009 na Faculdade de Direito: Luiz Gustavo Bambini de Assis. Processo legislativo e orçamento público: a função de controle do parlamento; Rubens Naman Rizek Júnior. O processo de consolidação e organização legislativa e Pedro Rubez Jehá. $O$ processo de degeneração dos partidos políticos do Brasil.
} 
processo de formação para além do texto da proposição legislativa, ao apreciar todos os demais elementos que influenciam e orientam o movimento de reforma legislativa.

Para tanto, a proposta é compreender, em primeiro lugar, as possíveis razões que levaram a ciência jurídica a negligenciar o estudo do processo de formação da norma, centralizando seu interesse na análise da lei vigente. Essa tarefa pressupõe um exame mais aprofundado da maneira como essa ciência se relaciona com outras ciências, como a política, e, mais especificamente, com o seu objeto de estudo, o direito.

A partir dessa análise, pretende-se aprofundar o estudo da relação entre política e direito no âmbito específico do direito penal e da política criminal, com vista a identificar qual dessas duas áreas do conhecimento tem se dedicado à tarefa de analisar o processo legislativo.

Esse esclarecimento permite identificar a forma como a ciência jurídica que se dedica ao direito penal compreende o processo legislativo e de que maneira se relaciona com esse espaço de formulação das normas que irão compor, depois de introduzidas no ordenamento jurídico, seu objeto de estudo.

Antes de prosseguir, entretanto, é preciso elucidar duas questões: a) a primeira sobre o que se entende por processo legislativo; b) a segunda sobre a proposta de delimitação do objeto desse trabalho ao direito penal e quais tipos de normas estão abrangidos nesse termo.

\section{a) processo legislativo}

Além de ser dotado de diversas fases, o processo de elaboração de normas apresenta características próprias, de acordo com o tipo de ato normativo que se pretende formular, quem é o seu autor e qual é a sua finalidade. Entender o funcionamento desse processo significa compreender, em última instância, a forma como se dá a positivação das normas, e, portanto, a origem do ordenamento jurídico vigente.

$\mathrm{O}$ ato de criação de normas pode ocorrer tanto nas três esferas de poder estatal (Legislativo, Judiciário e Executivo), no exercício do seu poder regulamentador, como ser 
identificado com a produção de normas em sentido amplo, isto é, englobando não só a lei, em suas diferentes modalidades, enquanto uma norma destinada a todos, cuja aprovação foi submetida ao Parlamento mediante a observância de um conjunto de regras previamente estabelecidas, como as normas emanadas pelos juízes no exercício da atividade de interpretação e aplicação da lei (decisões judiciais) e as que forem editadas pelo Poder Executivo, como as medidas provisórias ${ }^{8}$.

Especificamente sobre esse segundo sentido, de um lado, o processo legislativo corresponde ao procedimento que deve ser observado pelos órgãos competentes na tarefa de elaboração de atos normativos em geral, abrangendo leis complementares, leis ordinárias, medidas provisórias, decretos e resoluções, nos termos previstos no art. 59 da Constituição Federal de $1988^{9}$.

De outro, é possível conceber, em oposição a normas gerais e abstratas, a decisão judicial como um ato normativo que regulamenta um caso concreto, ainda que, nesse caso, não seja apropriado falar em processo legislativo, mas em aplicação/criação da lei no caso concreto ${ }^{10}$.

\footnotetext{
${ }^{8}$ Apesar de a Constituição Federal autorizar o Presidente da República a editar medidas provisórias em caso de relevância e urgência, veda essa edição quando se tratar de matéria relativa a direito penal, processual penal e processual civil (art. 62, $\S 1^{\circ}, \mathrm{I}, b$ ). Entretanto, é possível admitir que o Poder Executivo está autorizado a editar normas relacionadas ao direito penal quando se trata da concessão de indulto, graça ou anistia pelo Presidente da República (art. 84, XII, da Constituição Federal).

${ }^{9}$ Não é caso de tratar da distinção entre processo e procedimento tão discutida na teoria geral do processo judicial. Ambos os termos são utilizados para descrever um conjunto de atos concatenados com vista à produção de um ato final determinado, a lei, ainda que o termo processo possa ser utilizado de forma mais ampla, englobando o conjunto de atos que caracterizam o procedimento legislativo, mas também questões anteriores e posteriores a esse procedimento, tais como a forma como a demanda se transforma efetivamente em iniciativa legislativa. Além disso, o processo confere finalidade aos atos praticados em cada fase do procedimento. De acordo com Luiz Gustavo Bambini de Assis, "processualistas ressaltam haver uma tênue distinção entre processo e procedimento. Nunca é demais ressaltar que o segundo é pressuposto para a existência do processo em si. É a série de procedimentos que forma o processo. Esse, por sua vez, reveste-se de uma finalidade intrínseca. Deve-se ter em conta, então, que o sentido teleológico do processo legislativo, baseado em seus procedimentos sequenciais, tem como objetivo a formação da lei como instrumento de regulação das relações sociais" (Processo legislativo e orçamento público: a função de controle do parlamento. Tese de Doutorado, Faculdade de Direito da Universidade de São Paulo, 2009, p. 71).Ver, ainda, sobre a noção de procedimento legislativo, Menelick de Carvalho Netto. A sanção no procedimento legislativo. Belo Horizonte: Del Rey, 1992, p. 228-247.

${ }^{10}$ Nesse sentido, mesmo Hans Kelsen, para quem o conteúdo da norma inferior está determinado pela norma superior, admite que haja um grau de indeterminação, pois sempre fica uma margem de livre apreciação, razão pela qual "a norma do escalão superior tem sempre, em relação ao ato de produção normativa ou de execução que a aplica, o caráter de um quadro ou moldura a preencher por este ato". Nesse sentido, a interpretação judicial é uma operação mental que acompanha o processo de aplicação do direito a partir da norma superior até a norma inferior. Apesar de limitada pela norma superior, a decisão judicial no caso concreto apresenta-se como uma norma inferior, revelando, portanto, um processo de criação do direito (Teoria Pura do Direito. $4^{\mathrm{a}}$ ed. Trad. João Baptista Machado. São Paulo: Martins Fontes, 1994, p. 388-391).
} 
Considerando as diversas acepções mencionadas, é importante delimitar o objeto do presente estudo. Trata-se do processo de elaboração de atos normativos perante o Poder Legislativo, que resulta na aprovação de normas gerais, vinculantes e impessoais, excluindo-se as que forem emanadas com o intuito de regular seu funcionamento e a atividade de seus membros, tais como resoluções, decretos e instruções normativas.

Nesse sentido, uma vez que o presente trabalho volta-se à análise do processo legislativo penal, confere-se enfoque aos projetos de leis complementares e ordinárias, além das propostas de emendas à Constituição ${ }^{11}$, mais comumente empregados na regulamentação dessa matéria. Assim, daqui em diante o termo "proposição legislativa" será utilizado para designar especificamente esses atos normativos cujo conteúdo tenha relação com o direito penal.

É importante notar que a análise do processo legislativo não está reduzida, na perspectiva aqui adotada, ao exame do procedimento de elaboração de atos normativos previsto na Constituição Federal, isto é, do procedimento a ser observado pelo Congresso Nacional para que uma lei seja aprovada e, ao final, promulgada, com o intuito de assegurar sua constitucionalidade formal, tais como as regras de iniciativa, sanção e veto, quorum de aprovação, limitações materiais e temporais.

Na realidade, não se trata de examinar o aspecto formal desse procedimento, ou seja, quais são as regras estabelecidas pelo ordenamento jurídico que devem ser observadas no processo de elaboração normativa pelo Parlamento, mas seu aspecto material, substantivo.

Considerando que o processo legislativo, desse ponto de vista, é o resultado de um fenômeno sociológico complexo ${ }^{12}$, pretende-se analisá-lo na medida em que a

\footnotetext{
${ }^{11}$ Tanto as leis ordinárias quanto as leis complementares, ressalvada a exigência de aprovação por maioria absoluta em cada uma das casas do Congresso Nacional das últimas conforme dispõe o art. 69 da Constituição Federal, seguem as mesmas fases de tramitação: iniciativa; discussão; deliberação ou votação; sanção ou veto; promulgação e publicação. As propostas de emenda à Constituição devem ser aprovadas por três quintos dos congressistas e tramitar em dois turnos em cada uma das casas do Congresso Nacional, desde que não esteja em vigor intervenção federal, estado de defesa ou de sítio, nem se pretenda abolir a federação, o voto direto, secreto, universal e periódico, a separação dos Poderes e os direitos e garantias individuais. Ver, sobre o tema, Gilmar Ferreira Mendes e Nestor José Forster Júnior. Manual de redação da Presidência da República. $2^{\mathrm{a}}$ ed. rev. e atual. Brasília: Presidência da República, 2002, p. 105-113 e p. 116.

${ }^{12}$ José Luis Díez Ripollés. Política criminal y derecho penal. Estudios. Valencia: Tirant lo Blanch, 2003, p. 24-25. Ao tratar especificamente do processo de produção de normas penais, o autor divide em cinco fases o fenômeno sociológico complexo que antecede esse processo: em primeiro lugar, observa-se certo desajuste entre uma determinada realidade sócio-econômica e a situação jurídica que deveria atendê-la, surgindo
} 
demanda social é assimilada pelos órgãos governamentais para se apresentar, então, como uma proposição legislativa perante o Poder Legislativo, independentemente do autor dessa iniciativa ${ }^{13}$, e investigar a sua tramitação nesse órgão considerando a complexidade que a cerca.

Nesse sentido, o processo legislativo compreende uma sequência de atos que inclui a definição do problema, a elaboração de uma solução mediante o emprego de uma linguagem normativa, a apresentação da proposição legislativa perante o Poder Legislativo, sua tramitação e, por fim, a promulgação da lei.

Sobre esse panorama, duas observações podem ser feitas. A primeira é que a etapa de definição do problema relaciona-se inteiramente com a assimilação da demanda social pelo órgão ou entidade que pretende elaborar a proposição legislativa. Em segundo lugar, ainda que parte desse processo coincida com as regras formais previstas na Constituição Federal, destacando-se principalmente as etapas de apresentação e tramitação da proposição legislativa no Parlamento, a proposta não é analisá-las a partir da observância dessas regras no processamento de uma proposição legislativa determinada, como já mencionado, mas sob o viés dos interesses concretos em jogo que influenciam e direcionam as decisões que são tomadas durante esse processo.

É nessa perspectiva que se pretende examinar as formas de interferir nesse processo, com o intuito de verificar de que maneira os juristas podem atuar mobilizando recursos para influenciar não só o ato de aplicação das normas, mas também o modo de sua produção.

opiniões que defendem a adaptação do sistema jurídico às novas condições; generaliza-se, então, em toda sociedade a preocupação com essa inadequação, que se manifesta através de atitudes difusas de mal-estar ou de incômodos individuais, por vezes destacados pela mídia; os meios de comunicação entram definitivamente em ação, transformando a preocupação em um autêntico problema social; os grupos sociais de pressão assumem o protagonismo e canalizam as discussões públicas em prol de seus próprios interesses; por fim, ocorre a adequação da demanda ao debate parlamentar mediante a formulação do ato normativo.

${ }^{13}$ Lembre-se que a Constituição Federal atribui a iniciativa dos projetos de lei a diversos órgãos. Além de definir a competência das instâncias federativas (o art. 22 trata da competência privativa da União; o art. 23 da competência comum da União, Estados, Distrito Federal e Municípios; e o art. 24 da competência concorrente da União, Estados e Distrito Federal), a Constituição Federal confere a iniciativa das leis complementares e ordinárias a qualquer membro ou Comissão da Câmara dos Deputados, do Senado Federal ou do Congresso Nacional, ao Presidente da República, ao Supremo Tribunal Federal, aos Tribunais Superiores, ao Procurador-Geral da República e aos cidadãos, desde que observada a forma e nas hipóteses ali previstas (art. 61), especificando os casos em que a competência é privativa. De acordo com o art. 22, I, da Constituição Federal é competência privativa da União legislar sobre direito civil, comercial, penal, processual, eleitoral, agrário, marítimo, aeronáutico, espacial e do trabalho. 
b) processo legislativo penal

Um segundo esclarecimento que se faz necessário é sobre qual ramo do direito se refere o processo legislativo a ser estudado. Essa questão se coloca na medida em que a proposta é extrapolar os limites de análise da dogmática para além da norma posta, identificando no processo de formulação de atos normativos um espaço de atuação de diversos interesses. Assim, para que a análise não seja muito abrangente de forma que torne impossível indicar todos os fatores que influenciam esse processo, pretende-se delimitá-la ao ramo específico do direito penal.

Essa delimitação se faz necessária para evitar generalizações sobre o processo legislativo que não sejam comuns a todas as áreas do direito. De fato, além de possuir características específicas - por exemplo, a influência exercida pela mídia diante de acontecimentos violentos -, não se verifica no processo de formulação do direito penal, com algumas exceções, a influência de determinados fatores comuns em outras áreas do direito, como a pressão de grupos organizados em torno de interesses econômicos, privados ou institucionais ou a disputa em torno de questões orçamentárias ou fiscais ${ }^{14}$.

Ao tratar dessa questão em sua análise sobre o processo de produção da lei que dispõe sobre os crimes hediondos, Luiz Guilherme Paiva aponta algumas particularidades que devem ser levadas em conta no caso específico das leis penais. Segundo o autor, "em primeiro lugar, trata-se da institucionalização da forma mais violenta de coerção estatal, o que, por si só, justificaria a existência de controles institucionais e democráticos mais amplos. Em segundo lugar, a constante ocorrência de comoções públicas e a presença sistemática do tema em discursos eleitorais alteram o fluxo de influências e o cenário político que culminam em decisões legislativas" ${ }^{15}$.

Assim, além da necessidade de se delimitar a presente análise ao ramo específico do direito penal, é importante esclarecer que a intenção não é discutir se o

\footnotetext{
${ }^{14}$ As exceções a essa realidade começam a aparecer mais recentemente na discussão sobre a formulação de novas regras no direito penal diante da privatização de alguns serviços antes considerados atribuição exclusiva dos órgãos públicos. É o caso da fiscalização por monitoração eletrônica utilizada na execução penal, prevista na Lei $\mathrm{n}^{\mathrm{o}} 12.258$, de 15 de junho de 2010, que se vale de uma pulseira ou tornozeleira eletrônica para rastrear presos, comercializada por empresas privadas. Sobre a privatização desses serviços, especialmente no âmbito da execução penal, ver Laurindo Dias Minhoto. Privatização de presídios e criminalidade. A gestão da violência no capitalismo global. São Paulo: Max Limonad, 2000.

${ }_{15}$ Luiz Guilherme Mendes de Paiva. A fábrica de penas. Racionalidade legislativa e a lei de crimes hediondos. Rio de Janeiro: Revan, 2009, p. 19.
} 
melhor termo para designar esse ramo do direito é direito criminal ou direito penal ${ }^{16}$, nem tratar de outras minúcias relacionadas à sua classificação.

A intenção, com o emprego do termo direito penal é se referir especificamente ao conjunto de normas que regulamentam o exercício do poder de punir do Estado, quer em relação à tarefa de definir as condutas criminosas, quanto à forma como ocorre a persecução dessas condutas, as penas aplicáveis e o procedimento de aplicação dessas penas.

Note-se que a definição de direito penal aqui adotada não é uma síntese das várias concepções de direito penal ao longo da história, tão-pouco representa a escolha de uma delas ${ }^{17}$, mas pretende ilustrar apenas qual tipo de norma produzida pelo Parlamento, dentre as diversas possibilidades, quer-se examinar. A explicação, portanto, é orientada conforme o campo de análise, refletindo especificamente as proposições legislativas ali apresentadas.

Além disso, o intuito não é restringir a análise ao processo de elaboração de normas de direito penal em sentido restrito, mas considerar toda resposta ao fenômeno criminal que se traduza em regulamentação do direito penal material ou processual, isto é, tratar do sistema penal em suas diversas vertentes (direito penal, direito processual penal e direito de execução penal) ${ }^{18}$.

Como, portanto, identificar qual proposição legislativa é uma proposta que cria ou modifica o direito penal? Quer dizer, qual aspecto diferencia uma norma de direito

\footnotetext{
${ }^{16}$ Alguns autores buscam uma explicação histórica para a diferença entre os termos, afirmando que os países de tradição jurídica romana costumam designar esse ramo do direito de penal, enquanto os países da common law o qualificam como criminal. De outro lado, a opção por uma das duas denominações pode se relacionar à própria concepção de direito que se quer adotar. Se o enfoque for a resposta conferida ao crime, isto é, a pena, como a própria condição de existência do crime, e não apenas sua conseqüência jurídica, a denominação direito penal costuma ser a escolhida. Se, ao contrário, a pena não for imprescindível para a existência do crime, na medida em que outras conseqüências jurídicas são admitidas, concentrando-se na infração, a denominação utilizada é direito criminal, por ser mais abrangente. Sobre essa distinção, ver Nilo Batista. Introdução crítica ao direito penal brasileiro. $11^{\mathrm{a}}$ ed. Rio de Janeiro: Revan, 2007, p. 43-49.

${ }^{17}$ Sobre esse tema, ver Luis Jiménez de Asúa. Tratado de derecho penal, tomo I. Buenos Aires: Losada, 1950 , p. 26-38.

${ }^{18}$ Nilo Batista utiliza o termo "sistema penal" para designar "o conjunto de normas jurídicas que prevêem os crimes e lhes cominam sanções, bem como disciplinam a incidência e validade de tais normas, a estrutura geral do crime, e a aplicação e execução das sanções cominadas", ao lado de outro conjunto de normas que estão funcionalmente ligadas a essas, tais como, o direito processual penal, a organização judiciária e a lei de execução penal, relacionadas, da mesma forma, às instituições que desenvolvem suas atividades em torno da realização do direito penal (Introdução crítica..., p. 24-25).
} 
penal de qualquer outra norma produzida pelo Parlamento, concernente aos demais ramos do direito?

Conforme acima mencionado, pode-se afirmar que qualquer proposição legislativa que pretenda modificar uma lei penal ou processual penal ou de execução penal vigente é uma proposição legislativa de conteúdo penal. Entretanto, essa afirmação remete a outra questão: como saber se uma lei vigente é uma lei que regulamenta o direito penal em sentido amplo?

As codificações funcionam como um ponto de partida. Tanto o Código Penal (Decreto-lei $\mathrm{n}^{\mathrm{o}}$ 2.848/1940), quanto o Código de Processo Penal (Decreto-lei $\mathrm{n}^{\mathrm{o}}$ 3.689/1941) e a Lei de Execução Penal (Lei $n^{\circ}$ 7.210/1984) constituem uma compilação das principais normas relativas ao seu campo de regulamentação.

De outro lado, a Constituição Federal dispõe sobre os princípios gerais que devem orientar a aplicação da lei penal, relacionando-os ora com a sua formulação (princípio da legalidade e seus desdobramentos), ora com a sanção aplicada (princípio da responsabilidade individual) ${ }^{19}$, além de indicar, em alguns casos, quais condutas devem ser criminalizadas ${ }^{20}$.

Além disso, diversas leis esparsas estabelecem crimes e sanções, geralmente a partir da previsão de uma norma de comportamento seguida da imposição de uma norma de sanção (fazer $\mathrm{x}=$ pena $\mathrm{y}$ ), que deve ser executada quando se verificar que um delito foi cometido ${ }^{21}$. Essa construção é utilizada não só por leis especiais, mas também por leis gerais e corresponde à seguinte estrutura: Matar alguém. Pena - reclusão, de 6 (seis) a 20 (vinte) anos (art. 121 do Código Penal).

Assim, é possível afirmar que uma proposta que altere as leis gerais e especiais cujas normas sejam elaboradas a partir dessa estrutura é uma proposição legislativa que pretende modificar o direito penal ${ }^{22}$.

\footnotetext{
${ }^{19}$ Ver art. $5^{\circ}$, incisos XXXIX e seguintes, da Constituição Federal.

${ }^{20}$ Como exemplo, ver art. 225, $\S 3^{\circ}$, da Constituição Federal.

${ }^{21}$ Hans Kelsen. O que é justiça? São Paulo: Martins Fontes, 1997, p. 326.

${ }^{22}$ Não é o caso de questionar a forma como essa estrutura reflete uma maneira específica de pensar o direito penal, denominada por Álvaro Pires de "racionalidade penal moderna", segundo a qual há uma correspondência necessária entre norma de comportamento e norma de sanção, desconsiderando outras possíveis conseqüências jurídicas da prática de uma conduta prevista como crime (A racionalidade penal moderna, o público e os direitos humanos. Novos Estudos CEBRAP, n. 68, março 2004, p. 39-60), mas de
} 
Da mesma forma, estão incluídas nesse conjunto as proposições legislativas que busquem regulamentar determinações constitucionais de criminalização, assim como as normas que estabeleçam, ao invés de penas aflitivas como a prisão, outras conseqüências ao cometimento de uma conduta criminosa, como, por exemplo, a restrição de direitos, a reparação do dano ou, até mesmo, a conciliação das partes ${ }^{23}$.

Para incluir, ainda, as normas de direito processual e de execução penal, podese utilizar a distinção, feita por Hart, entre normas primárias e normas secundárias. As normas primárias determinam as condutas que os homens devem ou não devem fazer, enquanto as normas secundárias são consideradas parasitárias, pois, por meio delas, é possível criar novas regras do tipo primárias, extinguir ou modificar regras antigas ou determinar de diferentes modos a sua incidência ou fiscalizar a sua aplicação ${ }^{24}$.

Enquanto as normas primárias impõem deveres, as secundárias atribuem poderes, públicos ou privados, sendo que as normas secundárias estão conectadas às primárias porque especificam a forma como essas podem ser introduzidas, eliminadas ou modificadas, bem como determinam o que fazer caso sejam violadas ${ }^{25}$.

Dentre essas normas, portanto, é possível identificar as normas processuais e as normas de definição e de interpretação do direito penal, considerando, assim, não só a elaboração de normas que reproduzem o modelo de descrição de uma conduta (normas primárias), mas também as normas que se relacionam direta ou indiretamente com essa estrutura (normas secundárias), isto é, as normas que indicam quem, quando e como fazer caso as normas primárias sejam desrespeitadas.

Essa distinção pode ser ainda mais detalhada, conforme proposta realizada no relatório elaborado pela equipe de pesquisa da Escola de Direito da Fundação Getulio Vargas sobre a atividade legislativa em matéria penal no Brasil ${ }^{26}$.

utilizar essa classificação para identificar toda norma que atribua uma pena a uma conduta determinada como uma norma penal, ainda que outras normas penais fiquem de fora, como as que prevêem restrições de direitos diversas da liberdade.

${ }^{23}$ Ver, nesse sentido, Álvaro Pires. A racionalidade penal moderna..., p. 39-60.

${ }^{24}$ Herbert Hart. The concept of law. Oxford: Oxford University Press, 1961, p. 78-79.

${ }^{25}$ Herbert Hart. The concept of law..., p. 92.

26 Maíra Rocha Machado, Álvaro Penna Pires, Fernanda Emy Matsuda, Carolina Cutrupi Ferreira e Yuri Corrêa Luz. Atividade legislativa e obstáculos à inovação em matéria penal no Brasil. Série Pensando o Direito. Brasília: Ministério da Justiça, 2010, relatório gentilmente cedido pela Secretária de Assuntos Legislativos antes da publicação final. 
A partir da classificação apresentada por Hart, os pesquisadores identificaram as normas de comportamento como normas primárias e seis outros tipos de normas como secundárias: as normas de sanção, de processo, de inclusão/exclusão do programa, de definição ou interpretação, de organização judicial, de inclusão/exclusão social ${ }^{27}$.

As normas de sanção são todas aquelas que correspondem "à sequência de acontecimentos que se inicia com a indicação de uma pena na sentença condenatória e se conclui com a extinção da pena e de todos os seus efeitos" ${ }^{28}$, enquanto as normas de processo "estabelecem os mecanismos que permitem equacionar, conduzir e decidir sobre um conflito que possa ser objeto de intervenção penal", além de traçarem os direitos, poderes e deveres dos atores envolvidos ${ }^{29}$.

De outro lado, as normas de inclusão/exclusão no programa penal "estabelecem as condições gerais para que um determinado conflito possa ser assumido pelo direito criminal" ${ }^{30}$. É o caso da regra sobre o limite de idade para ser autor de um crime e do princípio da territorialidade. Enquanto as normas de definição ou interpretação esclarecem conceitos, as normas de exclusão/inclusão social estabelecem efeitos da intervenção penal que extrapolem a própria sanção e atinjam outras esferas sociais do indivíduo, como o direito de voto ou o impedimento de exercer determinada profissão ${ }^{31}$.

Apesar de se reconhecer a importância do aprofundamento trazido por essa classificação, a intenção aqui não é desenvolver uma tipologia das normas penais, mas apenas tentar demonstrar, com alguns exemplos trazidos pela pesquisa, de qual norma se está tratando, com o intuito de tornar mais claras as peculiaridades que envolvem esse ramo do direito e que refletem na sua elaboração, retomando-se, portanto, a seguir, a análise da maneira como se dá esse processo de criação de atos normativos.

\footnotetext{
${ }^{27}$ Maíra Rocha Machado et alli. Atividade legislativa..., p. 22.

${ }^{28}$ Maíra Rocha Machado et alli. Atividade legislativa..., p. 22.

${ }^{29}$ Maíra Rocha Machado et alli. Atividade legislativa..., p. 23.

${ }^{30}$ Maíra Rocha Machado et alli. Atividade legislativa ..., p. 23.

${ }^{31}$ Maíra Rocha Machado et alli. Atividade legislativa..., p. 23.
} 


\section{A relação entre o direito e a política}

É possível afirmar que o processo legislativo consubstancia-se como um ponto de encontro entre o direito e a política ${ }^{32}$. Se, de um lado, a elaboração de leis é uma ação política, uma vez que se apresenta como resultado da convergência de interesses comuns em razão de um fim determinado, ela é também uma operação jurídica, na medida em que é responsável pela formação da lei, uma das principais fontes do direito ${ }^{33}$.

Ocorre que a relação entre o direito e a política vem sendo negligenciada ao longo da história pelas ciências que poderiam se dedicar à sua análise. Se de um lado, os juristas buscam isolar o direito em relação às outras ciências humanas, tais como a política e a economia, de outro, tais ciências se recusam a examinar o direito por considerá-lo alheio à realidade, tendo em vista a importância que confere à norma.

Nesse sentido, Commaille afirma que o direito, enquanto objeto de estudo, é marcado por uma dupla pretensão: a de ser uma prática de natureza tão particular que somente ele pode dizer a verdade sobre si mesmo e o mundo social, afastando, assim, a possibilidade de qualquer relação interdisciplinar entre juristas e cientistas políticos, por exemplo; e a de se auto-intitular a verdadeira ciência da política, a quem caberia delimitar os fins e os valores da sociedade, mediante regras que se impõem por meio da força exercida exclusivamente pelo Estado ${ }^{34}$.

Assim, qualquer disciplina que se dedique ao seu estudo deve se configurar como um dos ramos do direito e se tornar autônoma em relação a sua disciplina de referência, tal como a filosofia do direito ou a história do direito, que se descolam da

\footnotetext{
${ }^{32}$ Utiliza-se, a princípio, o termo política para indicar "a atividade ou conjunto de atividades que, de alguma maneira, têm como termo de referência a pólis, ou seja, o Estado", em seu âmbito mais específico da tarefa de legislar através de normas gerais e impessoais (Norberto Bobbio; Nicola Matteucci e Gianfranco Pasquino. Dicionário de política, $5^{\text {a }}$ ed., v. 2, Brasília: UNB e São Paulo: Imprensa Oficial do Estado, 2000, p. 954.

${ }^{33}$ Segundo José Eduardo Faria, essa questão localiza-se na chamada política do direito: “o ramo da teoria geral do direito que representa, ao nível empírico-positivo, o ponto de convergência tanto da Política como do direito, pois enquanto toda fixação de regras de comportamento prende-se a fundamentos e finalidades, a permanência dos meios orientados para certos fins está condicionada à sua inserção em normas jurídicas" (José Eduardo Campos de Oliveira Faria. Poder e legitimidade. Uma introdução à política do direito. São Paulo: Perspectiva, 1976, p. 24).

34 Jacques Commaille. De la «sociologie juridique» à une sociologie politique du droit. In Jacques Commaille; Laurence Dumoulin e Cécile Robert. La juridicisation du politique. Paris: L.G.D.J., 2010, p. 30.
} 
filosofia e da história ao incorporar um modo de pensar característico da ciência jurídica na construção de seu objeto de estudo ${ }^{35}$.

Nesse sentido, o jurista adota um discurso de desqualificação da política, na medida em que, diante da sua suposta missão de definir o interesse geral a partir de regras universais, é capaz de evitar as temporalidades sociais e políticas, consideradas efêmeras e conjunturais ${ }^{36}$. Diante dessa visão, o jurista adota duas posições em relação às ciências sociais, de rejeição em nome da integridade do direito ou de superioridade ${ }^{37}$.

De outro lado, Commaille afirma que a rejeição do direito como objeto de estudo pela ciência política se explica pela sua necessidade de se afirmar como disciplina autônoma ${ }^{38}$, adotando um discurso de desqualificação de tudo que se refere ao direito e supervalorizando o fato com o intuito de rejeitar a norma, caracterizada como alheia a realidade ${ }^{39}$.

Essa forma de tratamento é, em última instância, reflexo da maneira como as ciências política e jurídica se relacionaram ao longo do seu desenvolvimento. De acordo com Chevallier, no começo do século XIX, direito e política buscaram delimitar seu espaço de atuação como forma de reconhecimento de sua própria autonomia ${ }^{40}$. De um lado, a ciência política visava deixar claro que a ciência jurídica deveria se restringir ao

35 Jacques Commaille. De la « sociologie juridique »..., p. 30. O autor discorda da visão defendida por Carbonnier, ao tratar a sociologia jurídica em oposição à dogmática do direito. Para Carbonnier, "a diferença não se relaciona com o objeto: é uma diferença de ponto de vista, de ângulo de visão. O mesmo objeto que a dogmática do direito analisa de dentro, a sociologia do direito observa de fora, pois o vê como fenômeno, como exterioridade, aparência, sem interrogar sobre o que ele pode ser em si mesmo, na sua profundidade ontológica, como essência”. Enquanto a dogmática está ligada ao interior do sistema jurídico, a sociologia, ao contrário, conhece a separação radical entre o observador e a matéria a ser observada. "E se o direito é Deus para o dogmático, o sociólogo se impõe a prática de um ateísmo metodológico" (tradução livre de Jean Carbonnier. Sociologique juridique. Paris: Quadrige/PUF, 2004, p. 16).

36 Jacques Commaille. De la « sociologie juridique »..., p. 31.

${ }^{37}$ Jacques Commaille. De la « sociologie juridique »..., p. 31.

${ }^{38}$ Jacques Commaille. De la « sociologie juridique »..., p. 34.

${ }^{39}$ Jacques Caillosse. À propos de l'analyse des politiques publiques: réflexions critiques sur une théorie sans droit. In Jacques Commaille; Laurence Dumoulin e Cécile Robert. La juridicisation du politique. Paris: L.G.D.J., 2010, p. 61. De acordo com Bastien François, a ciência política nasce a partir de uma separação, ou melhor, de uma tradição negativa: contra o direito e contra os juristas (Préalables avant de prendre le droit comme objet. Notations en forme de plaidoyer pour un point de vue a-disciplinaire mais néanmoins soucieux des impensés disciplinaires. In Jacques Commaille; Laurence Dumoulin e Cécile Robert. La juridicisation du politique. Paris: L.G.D.J., 2010, p. 120).

${ }^{40}$ Jacques Chevallier. Science du droit et science du politique d l'opposition a la complementarite. In Droit et Politique. Paris: PUF, 1993, p. 252. Segundo o autor, a ciência do direito, mais antiga, se deparou com uma ciência nova, cujo desenvolvimento na França data da segunda guerra mundial, ainda que seu surgimento possa ser identificado com o final do século XIX. Sendo assim, mesmo o direito, do ponto de vista da dogmática jurídica, é recente e seu desenvolvimento é concomitante ao das ciências sociais no final do século XIX, ou seja, não se trata exatamente de uma disputa temporal entre as duas ciências, mas de delimitação do objeto de cada uma delas, de um princípio de demarcação mútua. 
estudo da atividade de aplicação e interpretação da lei, enquanto, de outro lado, interessava aos juristas assegurar um campo de saber que fosse acessível apenas por eles.

Assim, como forma de assegurar sua autonomia, ambas as ciências buscaram delimitar seu campo científico: enquanto os juristas se propuseram o estudo das normas, o dever ser, aos cientistas políticos caberia a análise da realidade política que influencia diretamente o processo de construção do direito; do ponto de vista do método de observação, os juristas deveriam aplicar o método dedutivo e os cientistas políticos, o método indutivo; consequentemente, cada uma dessas ciências constrói paradigmas específicos que se perpetuam até os dias de hoje ${ }^{41}$.

Essa dissociação completa entre o direito e a política ficou clara especialmente a partir do triunfo da corrente positivista de análise do direito, que proclamava o respeito ao que era imposto pelo legislador ao não questionar a forma como as normas eram produzidas e defender a aplicação literal do texto ${ }^{42}$. $\mathrm{O}$ direito buscava sua autonomia, portanto, no culto à lei posta ${ }^{43}$.

Mais do que isso, em sua tentativa de afirmação como ciência, os juristas renegavam as questões técnicas, relacionadas com a prática, por considerá-las inadequadas à dignidade e nobreza do direito ${ }^{44}$.

A exclusão de todos os elementos exteriores à ordem jurídica na análise do direito garantia, assim, a autonomia da ciência jurídica, afastando a possibilidade de qualquer abordagem crítica do direito.

Segundo Chevallier, com o tempo, o desenvolvimento das ciências humanas e o questionamento do positivismo jurídico, a ciência jurídica tende a abandonar a pretensão

\footnotetext{
${ }^{41}$ Jacques Chevallier. Science du droit..., p. 257.

42 Jacques Chevallier. Science du droit..., p. 253. A análise kelseniana do direito possibilita a compreensão desse fenômeno: enquanto a ciência política analisa o ato de vontade que cria a norma, ao direito cabe o estudo da norma em si.

${ }^{43}$ Essa postura de culto à lei não impede que o jurista, depois do direito ser criado e posto, passe a compreendê-lo para além do texto imposto pelo legislador, a partir de uma estrutura lógico-formal de pensamento, aplicando-o a partir desse método de pensamento, denominado de jurídico (Antonio Castanheira Neves. A redução política do pensamento metodológico-jurídico. Boletim da Faculdade de Direito da Universidade de Coimbra, edição especial de homenagem ao prof. Doutor Afonso Rodrigues Queiró, 1993, p. 399). Não se pretende discutir, portanto, a relação entre direito e política da perspectiva da atividade judicial de aplicação das leis, que deu ensejo a diversas correntes de pensamento posteriores ao positivismo.

${ }_{44}$ Jean Dabin. Techinique de l'élaboration du droit positif. Bruxelles: Établissements Émile Bruylant e Paris: Librarie du Recueil Sirey, 1935, p. VIII e 1.
} 
de ser a ciência social por excelência, incorporando os métodos de outras ciências em sua análise ao admitir a possibilidade de uma aproximação sociológica dos fenômenos jurídicos ${ }^{45}$.

Da mesma forma, o autor aponta que a ciência política se mostra mais propensa a aceitar a importância do direito no seu campo de observação, na medida em que, sendo o poder político um dos seus objetos de estudo, o direito passa a ser compreendido como uma forma de expressão desse poder, por meio do qual ele se formaliza e é exercido ${ }^{46}$.

No Brasil, Marcos Nobre identifica dois elementos que podem ter contribuído para essa aproximação, a partir da década de 90: a consolidação do sistema universitário de pesquisa, em oposição ao bacharelismo que contaminava os cursos jurídicos até a primeira metade do século $\mathrm{XX}$, marcado pela "falta de rigor científico, o ecletismo teórico e uma inadmissível falta de independência em relação à política e à moral" ${ }^{47}$; e os efeitos sociais de Constituição Federal de 1988, que resultou “em acentuada 'juridificação' das relações sociais", além de ter se tornado referência central no debate político ${ }^{48}$.

Do ponto de vista crítico, atribui-se à divisão de tarefas acima mencionada, que se reproduz tanto na relação do direito com a política, como em sua relação com a sociologia, o resultado de limitar a investigação do direito. Em relação aos juristas, ao privá-los de instrumentos metodológicos necessários ao estudo da transformação do direito. A sociologia, de outro lado, é condenada a examinar apenas o direito aparente ou alguns fenômenos paralelos do direito, mas que não se configuram como direito em si ${ }^{49}$.

Entretanto, como se verá adiante, apesar desses avanços, a influência do positivismo jurídico é sentida até hoje no estudo do direito, perpetuando-se principalmente a partir de dois dogmas: a racionalidade do legislador e a soberania da lei, que funcionam

\footnotetext{
${ }^{45}$ Jacques Chevallier. Science du droit..., p. 254.

${ }^{46}$ Jacques Commaille. De la « sociologie juridique »..., p. 36. Sobre o aumento desse interesse, ver Anne Wyvekens. Entre politique et droit, la politique judiciaire de la ville. In Jacques Commaille; Laurence Dumoulin e Cécile Robert. La juridicisation du politique. Paris: L.G.D.J., 2010, p. 159-173.

${ }^{47}$ Marcos Nobre. Apontamentos sobre a pesquisa em direito no Brasil. Cadernos Direito GV, n. 1, setembro 2004 , p. 5.

${ }^{48}$ Marcos Nobre. Apontamentos sobre a pesquisa..., p. 5.

${ }^{49}$ Pierre Lascoumes e Évelyne Serverin. Le droit comme activité sociale: por une approche wébérienne des activités juridiques. Droit et Societé, n. 9, 1988, p. 175-176.
} 
como princípios reguladores das diversas operações intelectuais de definição, classificação, sistematização e interpretação do direito, às quais se dedica a dogmática jurídica ${ }^{50}$.

Como destaca Marcos Nobre, ao analisar os motivos que levaram o direito como disciplina acadêmica a não alcançar o crescimento qualitativo da pesquisa científica em ciências humanas, os juristas insistem, muitas vezes, em manter o ensino do direito fundamentado na transmissão de conhecimento sobre a prática jurídica dos profissionais que atuam nessa área, ao invés de seguirem critérios rigorosos de produção de conhecimento científico ${ }^{51}$.

É o que Tércio Ferraz Jr. denomina de "produção técnica, destinada apenas a atender às necessidades do profissional (o juiz, o advogado, o promotor) no desempenho imediato de suas funções", caracterizada por ser fechada e formalista ${ }^{52}$.

Trata-se, portanto, de uma tendência a estudar o direito como um "conhecimento demasiado restritivo, legalista, cego para a realidade, formalmente infenso à própria existência do fenômeno jurídico como um fenômeno social" 53 .

Conforme será analisado a seguir, é essa visão do positivismo jurídico, que reduz a dogmática a uma disciplina "intransigente, formalista e obstinada, que só vê o que as normas prescrevem" 54 que se quer afastar, possibilitando, assim, uma redefinição do seu papel.

\section{A análise do direito}

De certa forma, a ciência do direito pouco se preocupou, ao longo de sua história, com o processo legislativo, exceto sob o aspecto da sua regulamentação formal, outorgando-se a função de interpretar e sistematizar os preceitos legais, independentemente da forma como foram criados. Tudo ocorre como se a lei nascesse a partir de sua

\footnotetext{
${ }^{50}$ François Ost e Michel van de Kerchove. Jalons pour une theorie critique du droit. Bruxelles: Facultés Universitaires Saint-Louis, 1987, p. 100.

${ }^{51}$ Marcos Nobre. Apontamentos sobre a pesquisa..., p. 7.

${ }^{52}$ Tércio Sampaio Ferraz Jr. Introdução ao estudo do direito..., p. 48.

${ }^{53}$ Tércio Sampaio Ferraz Jr. Introdução ao estudo do direito..., p. 48.

${ }^{54}$ Tércio Sampaio Ferraz Jr. Introdução ao estudo do direito..., p. 48.
} 
publicação no diário oficial e sua interpretação a partir da vontade do legislador não vai além do exame da exposição de motivos ${ }^{55}$.

Isso porque o estudo do direito se manteve restrito, especialmente nos países de tradição romano-germânica ${ }^{56}$, à ordem vigente, tendo em vista sua elaboração a partir da instituição de dogmas, com o intuito de auxiliar o processo de tomada de decisões ${ }^{57}$.

Assim, em sua tarefa de definição, classificação, sistematização e interpretação das normas ${ }^{58}$, a dogmática jurídica estabelece uma série de premissas, que se apresentam como incontestáveis, mas que possibilitam a aplicação da lei ao caso concreto.

A ciência jurídica, portanto, que deveria ser considerada mais ampla do ponto de vista do seu objeto, na medida em que compreende em seu estudo uma análise externa do direito ${ }^{59}$, acabou se igualando à doutrina jurídica ${ }^{60}$, limitada pelos dogmas que sustentam seu objeto de estudo, tendo em vista a finalidade de solucionar conflitos sociais.

Para compreender essa questão, adota-se a distinção entre ciência e dogmática jurídica utilizada por Jacques Chevallier, com o intuito de verificar como a confusão entre elas prejudicou, em certa medida, a análise do direito.

\footnotetext{
${ }^{55}$ Georges Ripert. Les forces créatrices du droit. Paris: Librairie Générale de Droit et de Jurisprudence, 1955 , p. 80.

${ }^{56}$ Esse fenômeno também ocorre no direito anglo-saxão, porém, como explica Atienza, através de outro percurso, na medida em que a teoria positivista dominante na Inglaterra no começo do séc. XIX, influenciada por Bentham, partiu de uma distinção entre o que é e o que deveria ser o direito que deixava a legislação fora do seu campo de estudo. Austin distinguia o estudo do direito positivo (jurisprudencia), compreendido como o conjunto de mandatos de um soberano aos seus súditos, e a ciência da legislação, isto é, as propostas sobre o que deveria ser o direito, que pertencia à teoria moral e política. Revela-se, portanto, uma tendência a considerar o direito do ponto de vista judicial (de sua interpretação e aplicação) e a situar o legislador fora do marco jurídico, perspectiva adotada, segundo Atienza, por Hart e Raz. Além disso, Atienza destaca que tanto o realismo jurídico escandinavo quanto o americano se dedicaram ao estudo da produção legislativa do direito, mas a consideravam uma tarefa política, fora do campo de estudo da ciência do direito (Manuel Atienza. Argumentación y legislación. In La política legislativa penal en ocidente. Una perspectiva comparada. José Luis Diéz Ripollés; Ana María Prieto del Pino e Susana Soto Navarro (ed.). Valencia: Tirant lo blanch, 2005, p. 20-21).

57 Segundo Tércio Sampaio Ferraz Jr., "uma disciplina pode ser definida como dogmática à medida que considera certas premissas, em si e por si arbitrárias (isto é, resultantes de uma decisão, como vinculantes para o estudo, renunciando-se, assim, ao postulado da pesquisa independente)" (Introdução ao Estudo do Direito..., p. 48).

${ }^{58}$ Segundo François Ost e Michel van de Kerchove, a dogmática jurídica se ocupa do estudo sistemático de uma ordem jurídica particular. A questão que ela se impõe é: em determinada ordem jurídica, essa lei é aplicável a tal situação? Ou em determinada ordem jurídica, qual é o sentido que tal conceito possui? Qual é a função que exerce tal instituição? (Jalons pour une theorie critique du droit..., p. 44).

${ }^{59}$ Jacques Chevallier. Doctrine juridique et science juridique. Droit et Société, 50, 2002, p. 105.

${ }^{60} \mathrm{O}$ termo doutrina é utilizado aqui como sinônimo de dogmática na medida em que serve para designar o estudo sistemático do direito, que não apenas o descreve, mas visa também orientar as condutas humanas.
} 
Segundo Chevallier, enquanto a doutrina jurídica se situa dentro do direito e pretende contribuir ao bom funcionamento da ordem jurídica, com o intuito de lhe conferir coerência, eliminar as dissonâncias e resolver as contradições, a ciência jurídica, a partir de um ponto de vista reflexivo e crítico, deveria produzir um conhecimento desinteressado, desprovido de finalidades pré-estabelecidas ${ }^{61}$.

Ocorre que a ciência do direito não conseguiu se desenvolver sem essa identificação com a dogmática jurídica, privilegiando um ponto de vista interno ao direito e interessando-se apenas sobre o estudo da norma em si mesma e não às condições de sua produção ${ }^{62}$.

$\mathrm{Na}$ realidade, conforme menciona Chevallier, a distinção entre ciência e dogmática jurídica não é ao menos cogitada, seja no plano didático, seja metodologicamente, concebendo-se a análise científica do fenômeno jurídico como uma atividade dogmática e vice-versa ${ }^{63}$.

É nessa linha que se desenvolve, ao longo do séc. XIX, a Escola da Exegese. Praticante de um positivismo estrito, alheia a qualquer consideração de ordem política, inclusive sobre o processo de produção da norma, tal escola de pensamento privilegiava a aplicação literal do texto da lei ${ }^{64}$.

Dessa forma, uma vez publicada no diário oficial, a lei adquire um sentido objetivo, que independe do contexto em que foi editada e da intenção real dos seus redatores. Prevalece, então, a vontade de um legislador fictício, que se manifesta mediante a leitura do texto da lei ${ }^{65}$.

No mesmo sentido, Kelsen desenvolve, no século seguinte, sua teoria pura do direito, atribuindo à ciência política o estudo do processo de produção das normas, na medida em que ele é fruto de relações de força e de jogos de poder ${ }^{66}$.

\footnotetext{
${ }^{61}$ Jacques Chevallier. Doctrine juridique..., p. 106.

62 Jacques Chevallier. Doctrine juridique..., p. 111.

63 Jacques Chevallier. Doctrine juridique..., p. 104.

${ }^{64}$ Jacques Chevallier. Doctrine juridique..., p. 111.

${ }^{65}$ Zygmunt Ziembinski. La notion de rationalité du législateur. Archives de philosophie du droit, tome 23, 1978, p. 178. Conforme mencionado anteriormente, o texto da lei é assimilado a partir de um método próprio, jurídico, que concebe a interpretação enquanto explicitação do pensamento do legislador e encontra a solução para lacunas e antinomias dentro da sua própria estrutura normativa (Antonio Castanheira Neves. A redução política..., p. 399-400)

${ }^{66}$ Jacques Chevallier. Doctrine juridique..., p. 111.
} 
Assim, para além de afastar a análise política do direito, Kelsen é responsável pela concepção de um formalismo jurídico exacerbado, marcado pela preocupação de como o direito é produzido, independentemente de seu conteúdo.

Essa concepção do direito implica na sua compreensão "como formal estrutura ordenadora da vida social, a considerar como abstracção da matéria social ordenada ou sem referência a quaisquer intenções materialmente práticas, fossem elas a exigência ética da justiça, os valores e os fins" 67 .

É importante notar que defensores do positivismo jurídico, como Kelsen, não negam a vinculação entre o direito e a política, reconhecendo que o processo de criação de normas é fruto de uma vontade política; entretanto, preconizam a sua separação quando se trata de conceituar e analisar o direito, tarefas que devem ser realizadas sem qualquer referência à política ${ }^{68}$.

Essa postura metodológica de neutralidade política acaba contribuindo para a separação clara entre o momento de formulação e as atividades de interpretação, análise e concepção do direito, como se propor seu exame para além do direito posto fosse o mesmo que permitir a contaminação de sua estrutura por elementos externos.

Aliás, é justamente porque essas funções estão bem delimitadas que a solução para as incongruências da lei é geralmente atribuída ao Poder Judiciário, a quem cabe a tarefa de declarar a inconstitucionalidade e corrigir antinomias e distorções provocadas pela legislação e, até mesmo, substituir o Parlamento na decisão de questões socialmente relevantes ${ }^{69}$.

\footnotetext{
${ }^{67}$ Antonio Castanheira Neves. A redução política..., p. 400-401.

68 Dimitri Dimoulis. Positivismo jurídico: introdução a uma teoria do direito e defesa do pragmatismo jurídico-político. São Paulo: Método, 2006, p. 105-107. Segundo o autor, "o aplicador e o estudioso devem entender e implementar a vontade dos criadores de normas, distanciando-se de suas conviç̧ões morais e políticas. Essa opção não se justifica em nome de uma ingênua crença na neutralidade política do direito ou em virtude da, igualmente ingênua, crença na apoliticidade dos aplicadores e estudiosos. O objetivo é manter o rigor das decisões e afirmações sobre os conteúdos do direito. Somente quem adota uma postura de neutralidade política pode revelar e preservar a normatividade jurídica, respeitando a vontade do legislador" (Positivismo jurídico..., p. 107-108).

${ }^{69}$ Um exemplo dessa postura pode ser encontrado no voto do ministro do Supremo Tribunal Federal, Gilmar Mendes, proferido na ação direta de inconstitucionalidade n. 3.510, sobre a lei de biossegurança (Lei n. 11.105/2005), ao afirmar que "o Supremo Tribunal Federal demonstra, com esse julgamento, que pode, sim, ser uma Casa do povo, tal qual o parlamento. Um lugar onde os diversos anseios sociais e o pluralismo político, ético e religioso encontram guarida nos debates procedimental e argumentativamente organizados em normas previamente estabelecidas" (disponível em www.stf.gov.br, acesso em 17.08.2010).
} 
Apesar de se reconhecer a importância dessa função, de um ponto de vista crítico, pode-se afirmar, de acordo com Freund, que a redução de toda decisão ou iniciativa política a um processo judicial significa reconhecer que somente a soberania do juiz é verdadeira, juridificando-se, assim, toda questão política. No limite, o autor afirma que essa concepção revela uma idéia absurda de democratização, que ignora a especificidade do político em nome do imperialismo do direito ${ }^{70}$.

Além de seu isolamento em relação às demais ciências humanas, a ciência jurídica adota como uma de suas premissas a racionalização do processo de produção das normas, confiada a órgãos especializados, com competências bem definidas ${ }^{71}$.

Ao analisar o tema, Chevallier afirma que essa racionalidade presumida do direito é atestada por seus atributos intrínsecos. O primeiro deles é a sistematicidade, que implica na apresentação do direito como uma totalidade coerente, uma ordem unitária, isto é, um sistema de normas solidárias e hierárquicas, relacionadas entre elas por ligações lógicas e necessárias, conferindo clareza, simplicidade e certeza; o segundo é a generalidade, na medida em que a realidade social é apreendida pelo direito sob o prisma de conceitos abstratos, reagrupados em categorias cada vez mais largas e compreensivas, assegurando que as soluções aplicáveis aos casos particulares possam ser deduzidas de regras gerais; por fim, o terceiro é a estabilidade, pelo qual as normas jurídicas adquirem certa permanência, sendo possível, assim, que cada um possa prever as conseqüências de seus atos e conhecer a regra que será aplicada ao caso concreto ${ }^{72}$.

Inserida nessa lógica, a dogmática jurídica funciona para assegurar que, a partir da sistematização e interpretação de soluções concretas, aumente a coerência e o rigor das regras formais do direito. Segundo Chevallier, "não se trata só de estabelecer os elos necessários entre as produções jurídicas individuais, em revelar os princípios comuns subjacentes, mas de construir grandes sínteses, conferindo à ordem jurídica sua unidade e seu lugar sob o império da razão" 73 .

A necessidade de estabelecer a distinção entre dogmática e ciência jurídica auxilia a compreensão do papel de cada uma delas na análise do direito. De acordo com

\footnotetext{
${ }^{70}$ Julien Freund. Droit et politique. Essai de définition du droit. Archives de philosophie du droit, n. 16, 1971, p. 23.

71 Jacques Chevallier. L'État post-moderne. Collection Droit et Société, n. 35. Paris: L.G.D.J., 2008, p. 101.

72 Jacques Chevallier. L'État post-moderne..., p. 101.

${ }^{73}$ Tradução livre de Jacques Chevallier. L'État post-moderne..., p. 101.
} 
Chevallier, no instante que a ciência jurídica traz uma contribuição ao funcionamento da ordem jurídica, ela perde o status de ciência. Para que isso não ocorra, ela deve observar as exigências epistemológicas comuns às ciências sociais: o repúdio ao pragmatismo, ao normativismo e às ideologias ${ }^{74}$.

Tércio Ferraz Jr. não é tão radical em sua análise sobre a ciência jurídica. Mesmo reconhecendo a prevalência de uma visão dogmática do direito, defende que não há uma oposição entre ciência e dogmática jurídica, mas que esta é um dos aspectos daquela.

Segundo esse autor, há duas possibilidades de proceder a uma investigação científica: acentuando o aspecto pergunta ou o aspecto resposta. No primeiro caso, os conceitos, as premissas e os princípios ficam abertos à dúvida, conservando um caráter hipotético e problemático. O enfoque é, portanto, zetético. Já no segundo caso, não há questionamentos, mas pontos de partidas previamente delimitados e, portanto, as premissas são mantidas como inatacáveis, prevalecendo o enfoque dogmático ${ }^{75}$.

A partir dessa distinção pode-se afirmar que o enfoque zetético corresponde à investigação a que Chevallier atribuiria o caráter de científica, pois constituída por um conjunto de enunciados que visa transmitir informações verdadeiras sobre o que existe, isto é, constatações que adquirem um caráter descritivo, genérico, bem comprovado e sistematizado $^{76}$.

A diferença é que, para Chevallier, o jurista permaneceu atrelado apenas à dogmática, o que prejudicou a sua capacidade de questionamento das premissas que lhe aparecem como dogmas, enquanto para Tércio Jr. ele se revela como um especialista tanto em questões dogmáticas, quanto zetéticas, ainda que as primeiras prevaleçam ${ }^{77}$.

Para Chevallier, em razão da confusão entre ciência e dogmática jurídica, verifica-se um fenômeno de hipertrofia da dogmática, que aparece claramente na prevalência de um positivismo que o autor denomina de tecnicista, refletindo-se no lugar

\footnotetext{
74 Jacques Chevallier. Doctrine juridique..., p. 110.

${ }^{75}$ Tércio Sampaio Ferraz Jr. Introdução ao estudo do direito..., p. 40-41. Segundo Ferraz Jr. o fenômeno da positivação cortou a possibilidade da ciência do direito trabalhar com enunciados descritivos sobre a realidade, dedicando-se a enunciados voltados ao problema da decidibilidade de conflitos (Introdução ao estudo do direito..., p. 88-89).

${ }^{76}$ Tércio Sampaio Ferraz Jr. Introdução ao estudo do direito..., p. 42.

${ }^{77}$ Tércio Sampaio Ferraz Jr. A ciência do direito..., p. 46.
} 
secundário conferido às ciências sociais nas faculdades de direito e na importância atribuída ao conhecimento das regras em vigor ${ }^{78}$.

Na realidade, a redefinição do papel de cada uma acabaria por contribuir com o funcionamento do ordenamento jurídico, na medida em que ambas se libertam das restrições que se impõem a partir da falta de compreensão das tarefas que desempenham.

Segundo Chevallier, a doutrina jurídica é indispensável para consolidar o ordenamento jurídico, assim como o papel desempenhado pelo direito na vida social impõe o desenvolvimento de uma reflexão científica sobre ele, destacando-se, então, a importância da ciência jurídica ${ }^{79}$.

O esclarecimento da forma como cada uma deve atuar possibilita a compreensão de quais implicações suas análises exercem no funcionamento do direito e a consciência da natureza do trabalho de pesquisa que desempenham, do terreno em que se situam e da contribuição que pretendem trazer ao conhecimento ${ }^{80}$.

A partir dessa perspectiva, a proposta é rever a forma como a dogmática jurídica compreende o processo de elaboração normativa. De um lado, a confusão entre ela e a ciência jurídica impossibilitou esta de observar esse processo como um espaço de análise; de outro, a dogmática jurídica, restrita aos limites impostos por um positivismo tecnicista ${ }^{81}$, deixou de identificar o processo legislativo como um lugar de atuação e de formulação de propostas que contribuam para o aperfeiçoamento do ordenamento jurídico em vigor.

É nesse sentido que se pretende analisar alguns dogmas do direito, como a racionalidade do legislador. Se, conforme afirma Tércio Ferraz Jr., "o século XX entendeu

\footnotetext{
${ }^{78}$ Jacques Chevallier. Doctrine juridique..., p. 113.

${ }^{79}$ Jacques Chevallier. Doctrine juridique..., p. 115.

${ }^{80}$ Jacques Chevallier. Doctrine juridique..., p. 118.

${ }^{81}$ Independentemente de se discutir a pertinência desse termo, utilizado por Chevallier, conforme acima mencionado, o que se quer, ao empregá-lo, é se referir a uma postura radical do positivismo, relacionada com a redução do direito a um conjunto de proposições e conceitos formalmente encadeados, alheio à pluralidade da realidade empírica e a complexidade das relações sociais. Em oposição a essa postura, o positivismo pode se libertar de "parâmetros imutáveis e de premissas materialmente invariáveis", como afirma Ferraz Jr., e "institucionalizar a mudança e a adaptação mediante procedimentos complexos e altamente móveis". Segundo esse autor, "o direito positivado é um direito que pode ser mudado por decisão, o que gera, sem dúvida, certa insegurança com respeito a verdades e princípios reconhecidos, lançados então, para um segundo plano, embora, por outro lado, signifique uma condição importante para melhor adequação do direito à realidade em rápida mutação, como é a de nossos dias" (A ciência do direito..., p. 41).
} 
ingenuamente a positivação como uma relação causal entre a vontade do legislador e o direito como norma legislada ou posta", é preciso reformular essa concepção a partir de uma visão da positividade como decorrência de uma "experiência atual e corrente, que se modifica a todo instante e determina a quem se devam endereçar sanções, obrigações, modificações etc.", reconhecendo-se que, embora o direito não nasça da pena do legislador, de uma vontade historicamente situada, "a decisão do legislador, que não o produz, tem a função importante de escolher uma possibilidade de regulamentação do comportamento em detrimento de outras" 82 .

a) o princípio da racionalidade do legislador

Ao tratar especificamente da ausência de interesse dos juristas pelo processo de produção das normas, Luiz Guilherme Paiva remete sua análise aos dogmas que fundamentam o direito moderno. O primeiro deles, segundo o autor, é o dogma da racionalidade do legislador ${ }^{83}$, segundo o qual direito assume um papel de neutralidade política ao considerar irrelevantes os motivos que levaram o legislador a tomar determinada decisão no processo de formulação da lei e conferir a esse processo atributos de uma ação racional ${ }^{84}$.

Tal crença, construída para facilitar a redução da experiência jurídica ao que está previsto em lei ${ }^{85}$, é, na realidade, um pressuposto da ciência do direito, e mais especificamente, da hermenêutica jurídica, que o utiliza no processo de interpretação das normas vigentes, para assegurar a aplicação da lei ao caso concreto.

\footnotetext{
${ }^{82}$ Tércio Sampaio Ferraz Jr. Introdução ao estudo do direito..., p. 89.

${ }^{83}$ Luiz Guilherme Mendes de Paiva. A fábrica de penas..., p. 19.

${ }^{84}$ Luiz Guilherme Mendes de Paiva. A fábrica de penas..., p. 20.

${ }^{85}$ José Eduardo Campos de Oliveira Faria. O direito na economia globalizada. $1^{\text {a }}$ ed. $3^{\text {a }}$ tiragem, São Paulo: Malheiros, 2002, p. 44. De acordo com o autor, a "racionalidade do legislador" refere-se "à sua capacidade de (a) converter leis e códigos em técnica de controle social fundadas antes em mecanismos formais do que na coação pessoal; (b) fazer das normas jurídicas medidas universais de comportamento social não vinculadas a nenhum conteúdo material; (c) sistematizar, de modo coerente, a legislação sob a forma de uma hierarquia de normas superpostas, em cujo âmbito as inferiores se subordinam às superiores num movimento linear e unidirecional de fundamentação e validez; (d) forjar técnicas para a 'inter-individualização' processual dos conflitos com a finalidade de permitir o seu 'desarme', sua 'dispersão' e sua 'biodegradação' pelas instituições judiciais; e, por fim, (e) de se expressar por uma linguagem objetiva, clara, unívoca e precisa" ( $O$ direito na economia globalizada..., p. 44).
} 
Segundo Georges Ripert, “a lei se apresenta como uma medida necessária, imposta pela economia ou pelos costumes, e aceita antecipadamente pela opinião. Os verdadeiros motivos da regra, os interesses que ela satisfaz, as paixões que a inspiram, a resistência que manifestou, a luta que a sustentou, tudo isso fica escondido nos parágrafos que glorificam justiça e utilidade" ${ }^{86}$.

Nesse sentido, José Afonso da Silva afirma que "de fato, ao legislador compete, em sentido autêntico, tão-só revelar, em preceitos genéricos, as condutas normativas, já de si, jurídicas, por já serem substratos dos valores jurídicos. Sua interferência, como órgão do Poder, tem apenas o sentido de precisar, para o futuro, tais condutas, conferindo-lhes predeterminação, unidade e certeza. Essa é a função do Estado, como legislador" 87.

Assim, apenas a abstração de que o legislador, muitas vezes, é motivado por interesses circunstanciais e casuísticos, movido por impulsos irracionais e se utiliza de expressões lacunosas e inequívocas, possibilita a crença na elaboração de "normas genéricas e impessoais hierarquicamente dispostas em ordenamentos completos, sem lacunas ou antinomias" 88 .

Ao estabelecer a lei como seu ponto de partida, a ciência do direito assegura que o ordenamento jurídico, enquanto conjunto de normas, será interpretado de forma sistemática e a partir de regras pré-concebidas, garantindo, assim, sua coerência interna e autonomia.

François Ost e Michel van de Kerchove apontam quatro dimensões do princípio da racionalidade do legislador. A primeira delas refere-se ao plano lingüístico, segundo o qual o legislador é visto como um utilizador racional da linguagem natural e um criador racional da linguagem jurídica. Admite-se que, ao estabelecer uma lei, o legislador formulou suas prescrições de um modo preciso e unívoco no que se refere à língua nacional, respeitando, ainda, os usos e convenções da língua jurídica.

No plano da eficácia das ações humanas (praxeologia), considera-se que o legislador elabora o sistema jurídico de forma racional, isto é, evita criar antinomias,

\footnotetext{
${ }^{86}$ Tradução livre de Georges Ripert. Les forces créatrices du droit..., p. 80-81.

${ }^{87}$ José Afonso da Silva. Processo constitucional..., p. 22.

${ }^{88}$ José Eduardo Campos de Oliveira Faria. O direito na economia globalizada..., p. 45.
} 
lacunas e redundâncias, que ele dá um sentido útil a cada disposição, que ele adapta os melhores meios de que dispõe para atingir os fins que persegue.

Já no plano epistemológico, postula-se que o legislador é um observador atento da realidade social, deduzindo-se que a sua legislação não fere a natureza das coisas, nem o espírito das instituições.

Por fim, no plano axiológico, supõe-se que o legislador é perfeitamente determinado quanto aos fins que ele persegue e que os valores que ele promove se harmonizam num sistema coerente de preferências, isto é, que ele respeita a regra da justiça segundo a qual deve se aplicar um tratamento idêntico aos indivíduos que estão em situações essencialmente parecidas ${ }^{89}$.

Assim, a vontade do legislador não é uma vontade historicamente situada, de um membro particular do Parlamento, que elabora um projeto de lei de acordo com a sua compreensão do mundo. Para a dogmática jurídica, o legislador é uma pessoa fictícia, que atua de forma racional, na medida em que detém conhecimento suficiente para escolher o meio mais adequado para atingir determinados fins ${ }^{90}$.

b) o princípio da soberania do legislador

O segundo dogma do direito moderno, de acordo com Luiz Guilherme Paiva, é o império da lei, consubstanciado na premissa "da lei como expressão da vontade geral democraticamente expressa", que ignora um recente processo de crise da lei em razão do abuso do emprego de seu caráter simbólico pelo Estado, que tem contribuído cada vez mais para um aumento quantitativo e um decréscimo qualitativo da legislação ${ }^{91}$.

Nessa perspectiva, o direito existe apenas a partir do momento em que o Estado, pelos seus órgãos qualificados, impõe uma regra jurídica na forma de lei. François

\footnotetext{
${ }^{89}$ François Ost e Michel van de Kerchove. Jalons pour une theorie critique $d u$ droit. Bruxelles: Facultés Universitaires Saint-Louis, 1987, p. 101.

${ }^{90}$ Zygmunt Ziembinski. La notion de rationalité du législateur.., p. 176-177.

${ }^{91}$ Luiz Guilherme Mendes de Paiva. A fábrica de penas..., p. 22-23.
} 
Ost e Michel van de Kerchove personificam essa soberania estatal no legislador, concebido como criador supremo e último de toda regra de direito ${ }^{92}$.

Segundo os autores, a noção de soberania compreende três atributos essenciais: a supremacia, a unidade e a indivisibilidade ${ }^{93}$. A supremacia do legislador implica em sua independência externa em relação a outras autoridades jurídicas, estatais ou não, bem como em relação a qualquer outra ordem normativa, seja moral, natural ou divina. O legislador soberano reúne, portanto, o grau mais elevado de conhecimento do justo e a lei é a representação desse conhecimento ${ }^{94}$.

A unidade, de outro lado, pressupõe que todos os poderes remontam a uma fonte única, que pode variar dependendo da concepção adotada. Para Rousseau, por exemplo, seria o pacto social, enquanto para Kelsen seria a norma fundamental ${ }^{95}$.

Por fim, o exercício da soberania é indivisível, ainda que sua organização autorize a repartição de poderes entre diferentes órgãos ${ }^{96}$.

Dessa forma, o princípio da soberania do legislador confere ao conjunto de normas jurídicas um critério de pertencimento a um sistema comum, pois provenientes de uma mesma fonte, e um critério único de validação, ao remeter a validade do ordenamento a uma mesma autoridade, seja a vontade do legislador ou a norma considerada superior em determinada ordem jurídica ${ }^{97}$.

Na verdade, é na centralização do poder político pelo Estado que o positivismo jurídico encontra um terreno fértil para se desenvolver, pois se estrutura a partir da idéia de que só é direito o que for criado pelo legislador ${ }^{98}$.

Ao tratar do tema, Bobbio discorre sobre a "teoria da monopolização da produção jurídica por parte do legislador”, consubstanciada no dogma da onipotência do legislador ${ }^{99}$. Segundo o autor, com a formação do Estado moderno, "a sociedade assume

\footnotetext{
${ }^{92}$ François Ost e Michel van de Kerchove. Jalons pour une theorie..., p. 108.

${ }^{93}$ François Ost e Michel van de Kerchove. Jalons pour une theorie..., p. 108.

${ }^{94}$ François Ost e Michel van de Kerchove. Jalons pour une theorie..., p. 109.

${ }^{95}$ François Ost e Michel van de Kerchove. Jalons pour une theorie..., p. 110.

${ }^{96}$ François Ost e Michel van de Kerchove. Jalons pour une theorie..., p. 110.

${ }^{97}$ François Ost e Michel van de Kerchove. Jalons pour une theorie..., p. 111.

${ }^{98}$ Dimitri Dimoulis. Positivismo Jurídico..., p. 70.

${ }^{99}$ Norberto Bobbio. O positivismo jurídico. Lições de filosofia do direito. Trad. Márcio Pugliesi, Edson Bini e Carlos Rodrigues. São Paulo: Ícone, 1995, p. 38.
} 
uma estrutura monista, no sentido de que o Estado concentra em si todos os poderes, em primeiro lugar aquele de criação do direito" ${ }^{100}$.

Entretanto, para impedir arbitrariedades, o pensamento liberal se valeu de alguns expedientes constitucionais, sendo os principais "a separação dos poderes, pela qual o poder legislativo não é atribuído ao 'príncipe'(isto é, ao poder executivo), mas a um colegiado que age junto a ele, com a conseqüência de que o governo fica subordinado à lei”, e "a representatividade, pela qual o poder legislativo não é mais expressão de uma restrita oligarquia, mas da nação inteira, mediante a técnica de representação política" ${ }^{101}$.

O Estado aparece, portanto, como única fonte do direito, o que confere um poder quase ilimitado ao Parlamento, consubstanciando na idéia de que a lei é fruto de um poder soberano capaz de expressar a vontade geral da população.

\section{Positivismo jurídico e processo legislativo}

Percebe-se, portanto, que os dogmas que sustentam o direito, tais como os princípios da racionalidade e da soberania do legislador, funcionam como instrumentos de apoio a um sistema coerente de normas, cuja manutenção, ao menos aparente, é vista como necessária para evitar que, diante de sua função de resolver os conflitos sociais, o direito se mostre ineficaz, pois a descrença no seu funcionamento poderia levar a um colapso ao revelar a incapacidade estatal de fornecer respostas aos problemas sociais ${ }^{102}$.

Assim, dos princípios da racionalidade e da soberania do legislador, dogmas do direito moderno, decorrem um conjunto de convicções e valores largamente compartilhados pelos juristas, que teoricamente asseguram o funcionamento do ordenamento jurídico alheio a qualquer consideração de ordem política.

Diante de tal constatação, não se pretende questionar se o direito, enquanto conjunto de normas elaboradas com o intuito de serem aplicadas de forma eficaz na

\footnotetext{
${ }^{100}$ Norberto Bobbio. O positivismo jurídico..., p. 27.

${ }^{101}$ Norberto Bobbio. O positivismo jurídico..., p. 39.

${ }^{102}$ Como afirma Ziembinski, "um sistema incoerente de normas provoca o eclipse do prestígio do direito e causa inúmeras conseqüências desagradáveis: políticas e sociais" (tradução livre de Zygmunt Ziembinski. La notion de rationalité du législateur..., p. 182).
} 
resolução de conflitos, poderia existir sem os dogmas que o sustentam, isto é, se é da essência do direito estar ancorado em determinados pressupostos que lhe permitem cumprir sua função.

A intenção também não é questionar a importância do positivismo jurídico para a análise do direito, nem pensar em uma alternativa teórica a essa forma de estruturar e pensar o direito ${ }^{103}$.

O que se pretende é analisar em que medida tal sistema impediu os juristas de identificar no processo de elaboração das normas, renegado em nome da pureza do direito, um espaço de atuação, mediante a reformulação de suas premissas, que se mostra necessária diante um diagnóstico de crise atribuído à sua incapacidade de resolver os conflitos sociais.

De fato, como ressalta José Eduardo Faria, a concepção tradicional do direito como um sistema fechado, unitário, hierárquico, sem lacunas ou antinomias, vem sendo modificada por uma visão instrumental e interdisciplinar, sujeita a influência de fatores políticos, econômicos e sociais. Instado a corresponder à complexidade das realidades emergentes e aos problemas delas resultantes, e tendo que se submeter cada vez mais à comunicação com outras esferas de controle social, em busca de sua eficácia, o direito se vê frente a um dilema: o questionamento dos valores formalistas e dogmáticos sobre os quais se estruturou mediante a constatação de que os jogos político e econômico influenciam e alteram as bases sobre as quais tem sido concebido e interpretado ${ }^{104}$.

Em relação a esse processo de revisão de suas premissas, Castanheira Neves afirma que o direito começa a assimilar o político quando percebe que a decisão concreta não era mera reprodução do direito abstrato, mas também criadora do direito, isto é, não se tratava apenas de forma, mas de intenção material, de uma estrutura não só lógicodedutiva, mas prático-normativo-teleológica ${ }^{105}$.

Segundo esse autor, "tanto pelo carácter normativamente constitutivo ou criador das suas decisões jurídicas, como pela sua intencionalidade prático-normativa, o

\footnotetext{
${ }^{103}$ Para entender as diversas correntes de pensamento que formulam propostas alternativas, no que se refere a relação entre direito e política, ver Antonio Castanheira Neves. A redução política..., p. 407-433.

104 José Eduardo Campos de Oliveira Faria. O direito na economia globalizada..., p. 127.

${ }^{105}$ Antonio Castanheira Neves. A redução política..., p. 403.
} 
pensamento jurídico e os juristas enquanto tais aproximam-se do legislador, pensam e criam o direito como o legislador - com diferença quantitativa ou grau de liberdade e vinculação, decerto, mas sem essencial divergência qualitativa - e por isso o cânone de decidir judicativamente 'como se fora legislador', de início invocado apenas para o domínio restrito da integração das lacunas, se converteu num princípio metodológico geral em que todo o pensamento metodológico-jurídico se deveria reconhecer" ${ }^{106}$.

Entretanto, essa perspectiva provoca mais reflexos na atividade de interpretação do direito, tanto é que o próprio Kelsen, renegando a ideia de que o juiz deveria reproduzir exatamente a lei, compreende que as normas jurídicas oferecem apenas um quadro de várias soluções possíveis, dentro do qual o intérprete encontra uma margem de livre apreciação, adotando a opção adequada ao caso concreto do ponto de vista da política do direito.

Apesar disso, o reconhecimento do aspecto político do direito não foi suficiente para romper com algumas premissas positivistas, tais como a redução do pensamento jurídico ao seu conhecimento formal e a necessidade de correspondência entre a decisão e o direito posto, ainda que com maior grau de abertura. Da mesma forma, não foi capaz de modificar a forma como os juristas compreendem seu processo político de elaboração, voltando-se exclusivamente à tarefa de interpretação do direito.

O impacto dessas transformações será analisado no próximo capítulo; entretanto, antes de prosseguir, é importante observar que o isolamento do direito dos demais aspectos sociais, políticos e econômicos não impede que os conflitos sociais sejam assimilados pela política, a partir de um aparato de linguagem característico de sua visão sobre os problemas que deles advém. E se leis são criadas nesse contexto, elas irão refletir em mudanças no direito produzidas em decorrência da forma como esses conflitos foram compreendidos pelo Poder Legislativo, que é um órgão político.

\footnotetext{
${ }^{106}$ Antonio Castanheira Neves. A redução política..., p. 403-404. Segundo o autor, esse reconhecimento implica na tentativa de assimilação do pressuposto de ausência de uma intencionalidade normativa autônoma no direito, assumindo-se que "o direito não teria outros valores constitutivos, outros princípios fundamentadores e outros fins determinantes do que aqueles que numa perspectiva política (estratégicoteologicamente política) e politicamente (decisório-prescritivamente política) se lhe imputassem”. O reconhecimento dessa função política do direito não se limita a sublinhar a função política do direito, nem apenas reconhecer os efeitos políticos que a realização do direito produz na vida social, mas "visa sim afirmar que ao direito compete imediatamente e no seu específico sentido um objectivo político - o seu objectivo constitutivo seria a realização normativa de uma particular intenção e teleologia políticas - e ainda que, já por isso, os seus fundamentos e critérios seriam, a todos os níveis e em toda a actuação da ordem jurídica, fundamentos e critérios políticos" (Antonio Castanheira Neves. A redução política..., p. 405).
} 
Diante de problemas como a violência e a insegurança, por exemplo, é comum observar que os parlamentares, ao se apropriarem dos conflitos sociais a eles relacionados, acabam optando pela apresentação de projetos de lei que aumentam penas ou tipificam novas condutas como crime.

Em certa medida, isso ocorre porque a construção de determinada visão sobre a violência e a criminalidade, ao refletir o imaginário popular, viabiliza a atuação política e assegura sua manutenção no poder. Assim, mesmo que algumas medidas repressivas se mostrem ineficazes para resolver o problema da violência, elas funcionam como um instrumento de resposta política eficaz do ponto de vista simbólico ${ }^{107}$.

Entretanto, apesar de ser comum, no âmbito específico do direito penal, observar críticas às leis e a produção legislativa porque não são fruto "de uma conseqüente política criminal, mas antes erupções descoordenadas e motivadas por casos pontuais, quer da vida nacional, quer da vida internacional" 108 , os juristas seguem, em sua grande maioria, ignorando que a legislação vigente pode ser fruto de um debate democrático orientado à edição de uma lei legitimamente promulgada, do qual eles participem, insistindo em manter a neutralidade no que diz respeito ao processo político de elaboração normativa.

De acordo com José Eduardo Faria, o direito se encontra martirizado pelo dilema de ser "tecnologia de controle, organização e direção social, o que implica uma formação unidisciplinar, meramente informativa, despolitizada e adestradora, estruturada em torno de um sistema jurídico tido como auto-suficiente, completo, lógico e formalmente coerente; ou ser uma atividade verdadeiramente científica, de natureza problematizante, eminentemente especulativa e acima de tudo crítica - o que exige uma formação reflexiva, não-dogmática e multidisciplinar, organizada a partir de uma interrogação sobre a dimensão política, sobre as implicações sócio-econômicas e sobre a natureza ideológica de toda ordem jurídica" ${ }^{109}$.

\footnotetext{
${ }^{107}$ Sobre o tema, ver Carolina Dzimidas Haber. A eficácia da lei penal: análise a partir da legislação penal de emergência (o exemplo do regime disciplinar diferenciado). Dissertação de mestrado da Universidade de São Paulo, 2007.

${ }^{108}$ José de Faria Costa. A criminalidade em um mundo globalizado: um plaidoyer por um direito penal nãosecuritário. In José de Faria Costa e Marco Antonio Marques da Silva (coord.). Direito penal especial, processo penal e direitos fundamentais - visão luso-brasileira. São Paulo: Quartier Latin, 2006, p. 93.

109 José Eduardo Campos de Oliveira Faria. Justiça e conflito (os juízes em face dos novos movimentos sociais). 2a ed. rev. e ampl. São Paulo: Revista dos Tribunais, 1992, p. 50.
} 
No que se refere ao direito penal, a tarefa de participar da elaboração normativa é atribuída à política criminal, que se ocupa dos "princípios e recomendações para a reforma ou transformação da legislação criminal e dos órgãos encarregados de sua aplicação" ${ }^{110}$.

Considerada, por muito tempo, um subsistema do direito, a política criminal teve seu espaço cada vez mais reduzido nesse domínio em razão da importância que acabou sendo conferida às atividades de interpretação e aplicação do direito.

Por outro lado, em busca de sua autonomia, a política criminal ampliou seu campo de atuação para além do direito, cuja relação alcançou as decisões tomadas pelas instituições jurídicas, ultrapassando os limites da tarefa de formular diretrizes legislativas.

Assim, se de um lado, submete-se a política criminal ao direito por entendê-la como a disciplina que "estuda a orientação e os valores que segue ou protege, ou que deveria seguir ou proteger, a legislação penal”, ou seja, seu objeto de análise seria justamente "as orientações políticas, sociológicas, éticas ou de qualquer outra índole que se encontram em cada instituição do direito penal vigente" "111; de outro, amplia-se seu objeto, fortalecendo sua autonomia, para englobar o "conjunto de medidas, critérios e argumentos que os poderes públicos empregam para prevenir e reagir frente ao fenômeno criminal" 112 .

Conforme se verá adiante, as mesmas dificuldades constatadas na relação entre política e direito se reproduzem em um âmbito mais reduzido, entre política criminal e direito penal. Ao atribuir à política criminal a análise dos aspectos políticos, econômicos e sociais do processo de formulação de normas, o direito penal mantém o limite intransponível imposto pelo positivismo jurídico.

\footnotetext{
${ }^{110}$ Nilo Batista. Introdução crítica..., p. 34.

111 Tradução livre de Emiliano Borja Jiménez. Curso de politica criminal. Valencia: Tirant lo Blanch, 2003, p. 23.

${ }^{112}$ Tradução livre de Emiliano Borja Jiménez. Curso de política criminal..., p. 23. Segundo o autor, quatro consequências decorrem dessa definição: em primeiro lugar, integram o objeto da política criminal não só a legislação penal, mas também outro tipo de instituições que tenham como fim a erradicação ou prevenção do crime; em segundo lugar, ampliam-se também os órgãos que podem intervir, designando-se poderes públicos a União, os estados, os municípios e demais entidades locais; amplia-se, ainda, a função de repressão para a de prevenção do fenômeno criminal; por fim, deixa claro que se trata de um conjunto de conhecimentos que, de forma racional, buscam melhorar a legislação penal e utilizar outros mecanismos para enfrentar determinados comportamentos socialmente indesejados, mas esse conhecimento não pode ser classificado como científico (Emiliano Borja Jiménez. Curso de política criminal..., p. 24-25).
} 


\section{A relação entre direito penal e política criminal}

O processo de distanciamento entre a política criminal e o direito penal pode ser identificado a partir de dois fatores: a forma como o direito incorporou a política criminal em sua análise, associando-a diretamente ao direito posto e, do ponto de vista da política criminal, a busca de sua autonomia.

Assim, se de um lado, a política criminal não passa da forma como o Estado utiliza o direito para reagir contra o crime ${ }^{113}$, de outro, vem sendo identificada com uma estratégia mais ampla para lidar com o fenômeno criminal.

De fato, a partir dos anos 70, diversos estudiosos começam a defender a necessidade de um espaço de reflexão sobre política criminal autônomo, independente de penalistas e criminólogos ${ }^{114}$, com o intuito de evitar a forma reducionista que cada uma dessas ciências examina esse objeto.

Enquanto para os primeiros, a política criminal não seria nada além de um braço do direito penal, destinada a promover sua aplicação e revisão, para os criminólogos não passaria de um instrumento a ser utilizado na tarefa de aplicação das teorias criminológicas ${ }^{115}$.

É em busca dessa autonomia que Marc Ancel funda, em 1975, a revista Archives de Politique Criminelle, proclamando, em sua primeira edição a necessidade de separar a pesquisa em política criminal do estudo das normas ou dogmática penal, assim como da filosofia do direito ou da sociologia jurídica e do estudo comparativo do direito, na medida em que se trata de uma ciência com método e objeto próprios ${ }^{116}$.

113 Jacqueline Bernat de Celis. La politique criminelle a la recherche d'elle-meme. Archives de Politique Criminelle, n. 2, 1977, p. 7.

${ }^{114} \mathrm{Na}$ França esse fenômeno se evidencia com a criação do Centre de recherches de politique criminelle, em 1974, a realização de um colóquio internacional no mesmo ano, e o lançamento da Archives de politique criminelle, um ano depois, além de diversos artigos publicados sobre o tema (Jacqueline Bernat de Celis. La politique criminelle..., p. 3).

${ }^{115}$ Jacqueline Bernat de Celis. La politique criminelle..., p. 9. Segundo a autora, quando um jurista trata do tema, invariavelmente se restringe a uma análise da ordem jurídica em vigor, ao plano das regras formais previstas, pois, para ele, examinar a realidade é examinar as estruturas estabelecidas numa sociedade. De outro lado, se é um criminólogo quem estuda o tema, o enfoque é conferido à diferença entre as normas em vigor e a forma como realmente vivem os homens, com o intuito de transgredir a ordem e as instituições existentes (Jacqueline Bernat de Celis. La politique criminelle..., p. 11-12).

${ }^{116}$ Marc Ancel. Por une étude systematique des problèmes de politique criminelle. Archives de Politique Criminelle, n. 1, 1975, p. 15. Para o autor, de uma parte, se a pesquisa consiste na observação da política criminal tal como ela é (ou foi) praticada efetivamente em diversos países, trata-se do estudo de um fato 
Diante desse diagnóstico, Marc Ancel propõe a ampliação da concepção da política criminal em dois aspectos. O primeiro, relacionado com a identificação necessária entre direito penal e política criminal, e o segundo, às suas atribuições. Assim, para além de ter como núcleo a repressão do crime pelos meios e procedimentos do direito penal, a compreensão da política criminal deveria ser ampliada, englobando também o sistema processual penal e a política penitenciária ${ }^{117}$.

Além disso, considerando o seu papel de instrumento de enfrentamento da criminalidade, outra questão proposta é que a política criminal deveria ser entendida tanto sob o aspecto repressivo quanto preventivo.

Por fim, a política criminal deveria se situar em três níveis diferentes e complementares: legislativo, onde se determinam as opções decisivas; executivo, que concretiza as escolhas do legislador segundo os meios de execução à disposição; e judiciário, onde são tomadas as decisões coercitivas ${ }^{118}$.

No que diz respeito à criminologia, o autor propõe que, enquanto a sua função seria a de coletar informações sobre o fenômeno criminal, contrastando-as entre si, a política criminal deveria ser responsável pelas questões relativas às estratégias para prevenir e fazer frente à criminalidade, isto é, se a primeira realiza um estudo empírico da realidade criminal, a segunda atribui a esses elementos um aspecto valorativo, circunstancial e de oportunidade política, incompatível com o saber científico ${ }^{119}$.

social e, nesse sentido, a pesquisa consiste em uma ciência da observação; de outra parte, considerando os dados e os ensinamentos dessa observação, a pesquisa tende a revelar as melhores condições de uma organização racional de proteção social contra o crime. A política criminal é, então, considerada uma arte, mais do que uma ciência (Marc Ancel. Por une étude systematique..., p. 22).

${ }^{117}$ Marc Ancel. Por une étude systematique..., p. 17. Segundo o autor, as questões de ordem processual não podem ser descartadas na medida em que a política criminal é um sistema em ação (système en action) e o processo penal representa a concretização do sistema de direito criminal, ou seja, é "la mise en action du système de droit criminel”. De outro lado, para o autor, não é possível descartar os procedimentos e meios de ação penitenciários em razão da importância que representam as opções governamentais e as orientações administrativas adotadas sobre o tema.

${ }_{118}^{18}$ Marc Ancel. Por une étude systematique..., p. 18.

119 Emiliano Borja Jiménez. Curso de política criminal..., p. 72. Segundo o autor, "certamente a política criminal recorrerá ao saber criminológico para determinar a forma mais razoável de enfrentar o fenômeno delitivo, mas, em última instância, a eleição de um modelo, de uma estratégia ou de um mecanismo a levar em consideração não depende da racionalidade técnica, mas de fatores valorativos, muito mais conjunturais e históricos" (tradução livre). Nesse sentido, Marc Ancel afirma que a tarefa da política criminal é "estudar a evolução, o estado atual e o futuro dos sistemas de reação anti-criminal em função de sua finalidade, dos meios empregados e dos resultados obtidos. Não se trata de uma ciência abstrata ou de especulação teórica, mas de uma observação rigorosa das realidades do direito criminal e da justiça penal, tal como funcionam efetivamente" (tradução livre de Marc Ancel. Por une étude systematique..., p. 15). 
Não é o caso de aprofundar a discussão sobre o caráter científico da política criminal, mas de identificar como os juristas não acompanharam essas mudanças e continuaram a concebê-la de forma reducionista, vinculando-a diretamente aos limites da dogmática do direito penal, sem reconhecer a conquista de sua autonomia.

Isso porque a política criminal pode ser entendida tanto como uma manifestação do poder do Estado, que adota diversas medidas e estratégias para enfrentar a criminalidade, quanto como um conjunto de conhecimentos sobre esse conjunto de medidas e estratégias, isto é, como um saber ${ }^{120}$.

No âmbito específico do processo legislativo, embora se constate certa preocupação dos penalistas com a política criminal, a relação permanece estanque: ainda que se reconheça que a norma jurídica advém de uma decisão política, o direito penal serve como filtro que confere unidade e coerência à proposta político-criminal, "ao ensaiar uma interpretação coerente das decisões político-legislativas" ${ }^{121}$.

Os aspectos políticos da formulação legislativa em matéria penal se situam, portanto, fora do direito, sendo que a conquista de autonomia da política criminal serviu para aumentar ainda mais esse fosso.

\section{Direito penal e política legislativa}

Considerando que apenas recentemente a política criminal passou a ser estudada como uma disciplina autônoma, torna-se necessário recorrer ao direito penal para analisar a forma como este a concebia, identificando-se em que medida ela era compreendida como sinônimo de política legislativa.

Ao buscar a origem da política criminal, Jiménez de Asúa encontra, no final do século XVIII, a primeira referência ao termo, na obra dos alemães Kleinsrod e Feuerbach.

\footnotetext{
120 Moisés Moreno Hernández. La política criminal legislativa. In Moisés Moreno Hernández (coord.). Orientaciones de la politica criminal legislativa. México: Inacipe, 2005, p. 133.

${ }^{121}$ Eugenio Raúl Zaffaroni e José Henrique Pierangeli. Manual de direito penal brasileiro. Parte geral. $3^{\mathrm{a}}$ ed. São Paulo: Revista dos Tribunais, 2001, p. 135.
} 
Enquanto Feuerbach a concebe como a "sabedoria do Estado legiferante", Kleinsrod a define como "o conhecimento dos meios que o legislador pode e deve encontrar, segundo a especial disposição de cada Estado, para impedir os delitos e proteger o direito natural de seus súditos" 122 .

Para Kleinsrod, "direito criminal e política criminal podem se relacionar em um sistema, ao perguntar-se sobre um ponto particular: como pode ser isso, ou como deve ser? Como é segundo a legislação positiva?" ${ }^{123}$.

Em seu Manual de Direito Penal, publicado em 1803, Feuerbach definiu a política criminal como o conjunto de procedimentos repressivos pelos quais o Estado reage contra o crime ${ }^{124}$. De acordo com Levasseur, para Feuerbach, a política criminal não é apenas um braço, mas o sentido em si do direito penal, é o direito penal orientado a um fim $^{125}$.

Tais definições indicam que, nessa época, o centro da análise proposta pelos estudiosos do direito penal era a política criminal enquanto política legislativa. De fato, autores como Beccaria, a quem Jiménez de Asúa atribui uma primeira tendência científica de revisão crítica das leis punitivas com apoio em direitos fundamentais, promovem o avanço da política criminal sob o aspecto de crítica da legislação vigente e possibilidade de propor sua reforma ${ }^{126}$.

Carrara, um dos poucos autores que se dedicou ao tema, propôs no final do século XIX a superação dos limites de identificação entre ciência e dogmática, estendendo o âmbito de competência da primeira para incluir o estudo da política criminal e da legislação ${ }^{127}$.

${ }^{122}$ Tradução livre de Luis Jiménez de Asúa. Tratado de derecho penal, tomo I. Buenos Aires: Losada, 1950, p. $139-140$.

${ }^{123}$ Tradução livre de Franz Von Liszt. Tratado de derecho penal, tomo II. Trad. Luis Jiménez de Asúa. Madrid: Reus, 1927, p. 53.

${ }^{124}$ Georges Levasseur. La politique criminelle. Archives de philosophie du droit, n. 16, 1971, p. 132.

${ }^{125}$ Georges Levasseur. La politique criminelle..., p. 132.

${ }^{126}$ Luis Jiménez de Asúa. Tratado de derecho penal..., p. 139.

${ }^{127}$ Alberto Cadoppi. Introduzioni. In Francesco Carrara. Lineamenti di pratica legislativa penale. Bologna: Mulino, 2007, p. 13. Curiosamente, o autor descreve que o interesse de Carrara pelo processo de formulação legislativa adveio de uma questão prática: a Itália tinha acabado de ser unificada, sendo que a unificação da legislação ainda não estava completa, especialmente no âmbito penal. O emprego do código penal sardo se estendeu pela Itália, exceto na Sicília e na Toscana, onde Carrara se formou em direito, sofrendo, portanto, as influências desse dispositivo legal. Ademais, o código sardo mantinha a pena de morte, abolida no código toscano. Carrara se manifestou veementemente contra a adoção do código sardo em todo território nacional, especialmente quando, em 1888, começava-se a realizar o projeto de novo código penal e era preciso decidir 
Ao se perguntar sobre o status de ciência da doutrina que estuda o estilo das leis e que dita regras gerais capazes de guiar o legislador na formulação de preceitos legislativos, o autor diferencia a ciência, puramente especulativa, do ato de escolher o melhor modo para atuar de acordo com princípios estabelecidos, considerado uma arte, pois consiste nos meios práticos de assegurar a obediência da lei e de atingir os fins, já revelados pela ciência ${ }^{128}$.

Para Carrara, entre o processo de formulação da fillosofia do direito penal e sua identificação como ciência e a fase de interpretação do direito e sua aplicação ao caso concreto existe uma fase intermediária, denominada doutrina da prática legislativa (dottrina della pratica legislativa), cuja importância significa trazer para a vida real um campo de pensamento, traduzir em artigos de lei uma verdade científica, que, a partir de uma linguagem clara, coerente e simples afastem o arbítrio estatal ${ }^{129}$.

$\mathrm{Na}$ mesma época, Bentham chamou a atenção para a necessidade de desmascarar o direito, mediante a compreensão de que a lei é produto da vontade humana, sendo necessário, portanto, afastar a obscuridade e a complexidade que a caracteriza, resultado do uso de expressões ambíguas e controversas ${ }^{130}$.

Assim, autores como Bentham e Beccaria buscaram aproximar a lei de seus destinatários, vislumbrando nos princípios da legalidade e da igualdade perante a lei a segurança de que não seriam cometidas arbitrariedades na aplicação do direito.

É preciso situar essas teorias no contexto em que estão inseridas, de crítica ao regime absolutista. A lei é vista, nesse aspecto, como um instrumento de combate à lentidão da transformação pelos costumes, que não favorece as mudanças. É a lei, portanto, que irá viabilizar a realização de reformas sociais profundas ${ }^{131}$.

qual modelo seria tomado como referência. Além das questões materiais, Carrara criticava a forma como havia sido redigido o código sardo. O autor preconizava uma técnica legislativa capaz de fazer uma descrição sintética, de forma geral e abstrata, das normas penais (Alberto Cadoppi. Introduzioni..., p. 17-19 e 28).

${ }^{128}$ Alberto Cadoppi. Introduzioni..., p. 16.

${ }^{129}$ Francesco Carrara. Lineamenti di pratica legislativa penale. Bologna: Mulino, 2007, p. 44-45.

${ }^{130}$ Herbert Hart. La demystication du droit. In Philippe Gérard, François Ost e Michel van de Kerchove. Actualité de la pensée juridique de Jeremy Bentham. Bruxelas: Facultés Universitaires Saint-Louis, 1987, p. 92-93 e 99.

${ }^{131}$ François Ost. Codification et temporalité dans le pensée de J. Bentham. In Philippe Gérard, François Ost e Michel van de Kerchove. Actualité de la pensée juridique de Jeremy Bentham. Bruxelas: Facultés Universitaires Saint-Louis, 1987, p. 164-165. 
Com o desenvolvimento do positivismo jurídico, o enfoque conferido à atividade legiferante em si foi dando lugar à proposta de exame da legislação sem “considerações políticas prévias ao ordenamento" ${ }^{132}$, ou seja, ainda que fosse feita, como propuseram os autores iluministas, uma análise crítica da legislação vigente, essa atividade era posterior e permanecia restrita aos limites do direito posto.

É nesse sentido que Jiménez de Asúa afirma que a política criminal "não é mais que parte do direito penal, como corolário da dogmática: crítica e reforma”. Segundo o autor, quando um dogmático examina o código penal e percebe que algumas disposições não concordam com a época contemporânea, ou simplesmente não respondem à eficácia do direito e das sanções, então é o próprio dogmático, como parte de seus ensinamentos, quem deve apontar onde estão os defeitos e de que forma podem ser corrigidos ${ }^{133}$.

Essa posição é reflexo da concepção de Franz Von Liszt sobre a política criminal. Segundo ele, as duas funções principais da política criminal são a crítica da legislação penal vigente, de acordo com as finalidades do direito e da pena e a observância de seus resultados e, a partir daí, as propostas de reforma do direito penal atual ${ }^{134}$.

Ao afirmar que "o direito penal constitui a barreira infranqueável de toda política criminal”, Liszt procurava deixar claro que qualquer estratégia de luta contra o crime formulada pelo Estado esbarra nos limites próprios do direito penal e deve respeitar seus princípios estruturais ${ }^{135}$. De acordo com Liszt, “entre a política criminal e o direito penal existem limites insuperáveis como os que existem entre a política e o direito" ${ }^{136}$.

Assim, ainda que tivesse conferido certa autonomia à política criminal em relação ao direito penal, a sua tarefa de fazer frente ao fenômeno criminal poderia ser executada mediante o emprego de todos os meios que estivessem ao seu alcance, mas encontraria seu limite no conjunto de garantias do cidadão, postulado pelo direito penal. A dogmática se apresenta, então, como um muro de contenção, como barreira intransponível frente à tendência de abuso de poder do Estado ${ }^{137}$.

\footnotetext{
${ }^{132}$ Luiz Guilherme Mendes de Paiva. A fábrica de penas..., p. 27-28.

${ }^{133}$ Luis Jiménez de Asúa. Tratado de derecho penal..., p. 143.

${ }^{134}$ Franz Von Liszt. Tratado de derecho penal..., p. 63.

${ }^{135}$ Emiliano Borja Jiménez. Curso de política criminal..., p. 33.

${ }^{136}$ Franz Von Liszt. Tratado de derecho penal..., p. 65.

${ }^{137}$ Emiliano Borja Jiménez. Curso de politica criminal..., p. 33.
} 
Ainda que Roxin, anos depois, tenha buscado uma nova fundamentação do sistema penal ao conferir às tradicionais categorias do fato criminoso - tipicidade, antijuridicidade e culpabilidade - precisas funções de política criminal $^{138}$, retomando, assim, a importância do tema, sua proposta manteve a análise a partir de diretrizes internas à teoria do delito, sem considerações prévias ou externas ${ }^{139}$.

Ao reafirmar os valores da política criminal como ponto de referimento para orientar o sistema penal ${ }^{140}$, Roxin destaca o perigo de uma dogmática fundada em fórmulas abstratas, de um juiz que se apega ao automatismo dos conceitos teóricos, sem se ocupar da particularidade do caso concreto ${ }^{141}$. Nesse sentido, conclui que uma elaboração sistemática pode garantir resultados unívocos e uniformes, mas não justos do ponto de vista substancial ${ }^{142}$.

Assim, Roxin afirma que direito penal e política criminal não se colocam em uma relação de antítese, como vinha reforçando a doutrina penal. O direito penal é, segundo o autor, a norma na qual os objetivos de política criminal são traduzidos em termos juridicamente válidos ${ }^{143}$.

Se Roxin preconizou a construção de um modelo teórico que considere as conseqüências político-criminais e as repercussões da aplicação dos institutos penais no âmbito da realidade social, sua proposta esbarrou nos limites da dogmática penal, que não leva em conta as decisões de política criminal do legislador antes da positivação, isto é, antes do ingresso desses preceitos no ordenamento jurídico, pois refletem um conflito social prévio, já solucionado pelo legislador ${ }^{144}$.

Mesmo que se atribua ao autor a conquista de uma posição de anterioridade e superioridade da política criminal perante o direito penal ${ }^{145}$, esse papel só pode ser

\footnotetext{
138 Sergio Moccia. Presentazione alla prima edizione italiana. In Claus Roxin. Politica criminale e sistema del diritto penale. Saggi di teoria del reato. Trad. Sergio Moccia. Napoli: Edizioni Scientifiche italiane, $\mathrm{p}$. 21.

${ }^{139}$ Luiz Guilherme Mendes de Paiva. A fábrica de penas..., p. 28.

${ }^{140}$ Sergio Moccia. Presentazione..., p. 29.

141 Claus Roxin. Politica criminale e sistema del diritto penale. Saggi di teoria del reato. Trad. Sergio Moccia. Napoli: Edizioni Scientifiche italiane, p. 40-41.

${ }^{142}$ Claus Roxin. Politica criminale..., p. 40.

${ }^{143}$ Claus Roxin. Politica criminale..., p. 76.

${ }^{144}$ Claus Roxin. Politica criminale..., p. 51, nota de rodapé 41.

145 Jacqueline Bernat de Celis. La politique criminelle a la recherche d'elle-meme. Archives de Politique Criminelle, n. 2, 1977, p. 8.
} 
exercido por meio do direito penal, pois apenas através de sua aplicação é que os objetivos da política criminal podem ser afirmados ${ }^{146}$.

Se inicialmente verifica-se um impulso do direito penal ao tema da política legislativa, ao longo do tempo, a concepção dessa política se amplia, construindo-se a partir dos instrumentos a disposição do Estado para combater a criminalidade.

Dessa transformação advêm duas consequências: a primeira é que, ao direito, importa a forma como as finalidades político-criminais do Estado perpassam os institutos penais e se fazem presente por meio das normas postas ${ }^{147}$; a segunda é que qualquer outra consideração sobre as decisões que foram tomadas para que essas finalidades se estabeleçam ou sejam traduzidas em norma não interessa ao direito, mas à política.

Assim, enquanto fonte de inspiração do legislador, a política criminal fornece diretrizes que devem ser observadas na tarefa de adequação do direito à evolução social ${ }^{148}$.

Se essas diretrizes orientam o direito penal em diversas definições, tais como, sobre quando criminalizar ou descriminalizar novas formas de condutas sociais, qual modelo de responsabilidade penal adotar, quais os limites das causas de justificação, como se dá a distribuição da repressão em casos de participação, ou qual a finalidade da pena ${ }^{149}$, bem como o direito processual, sobre o exercício da ação pública, o tratamento conferido às provas, os limites dos poderes judiciais ${ }^{150}$, e a execução penal, no que se refere, por exemplo, ao modelo de encarceramento e de cumprimento das penas ${ }^{151}$, não é função dos juristas compreenderem a forma como o legislador se apropria desse conteúdo, conferindo ao conjunto de regras em formação a coerência que dele será exigida após adquirir a qualidade de direito posto.

Se, como afirma Levasseur, as relações que unem política criminal e direito penal são particularmente diretas e estreitas, pois a política criminal se alimenta de fontes diversas e complexas, domina o conjunto das concepções repressivas do Estado e utiliza,

\footnotetext{
${ }^{146}$ Jacqueline Bernat de Celis. La politique criminelle..., p. 8.

${ }^{147}$ É nesse sentido que Luis Jiménez de Asúa afirma que a política criminal não é nada além do que a arte de transpassar à legislação positiva a aspiração proveniente de ideais (Tratado de derecho penal..., p. 144).

${ }^{148}$ Georges Levasseur. Politica Criminal y Derecho Penal. Revue Internationale de Droit Pénal, n. 1, 1978, p. 156.

${ }^{149}$ Georges Levasseur. Politica Criminal..., p. 156-157.

${ }^{150}$ Georges Levasseur. Politica Criminal..., p. 159-160.

${ }^{151}$ Georges Levasseur. Politica Criminal..., p. 161-162.
} 
para servir aos seus fins, as medidas previstas no direito penal ${ }^{152}$, há, no mínimo, uma contradição na opção dos juristas de não auxiliar ou participar dessa tarefa, ou, ao menos, de não considerá-la na sua análise.

\section{As diversas acepções da política}

No início do presente capítulo, afirmou-se que um possível espaço de intersecção entre o direito e a política é o processo legislativo, ainda que a relação entre ambos tenha sido de isolamento. Em seguida, em um contexto mais específico, percebe-se que tal característica se reproduz em relação ao direito penal e a política criminal.

Se inicialmente a política criminal era concebida pelos juristas como sinônimo de arte de legislar, com o tempo, em busca de sua autonomia, adquiriu amplitude para além do direito penal, identificando-se com os princípios e recomendações voltados a repressão e prevenção do crime, não sendo mais possível reduzi-la ao papel de "indicar ao legislador onde e quando criminalizar condutas" ${ }^{153}$, na medida em que passa a atuar de forma individualizada sobre o delinquente, como pretendia Liszt.

Entretanto, essa função não foi assumida pelo direito penal, mantendo-se a distância que o separa do processo legislativo. Conforme analisado, ainda que se constate a preocupação de alguns juristas com a política criminal, compreendida em sua vertente legislativa, ao longo do tempo, consolidou-se a postura de delimitação das questões político-criminais ao âmbito do direito vigente, mantendo-se a separação entre direito penal e política criminal.

Para compreender a relação entre política criminal e direito penal, é necessário esclarecer, antes de prosseguir, qual sentido do termo política se quer adotar, pois, segundo Raymond Aron essa palavra pode adquirir diversos significados.

Em primeiro lugar porque, nas línguas latinas, é utilizada para traduzir duas palavras diferentes da língua inglesa: policy e politics ${ }^{154}$. No primeiro sentido, refere-se "a um programa de ação, a um método de ação ou a ação em si de um indivíduo, de um grupo

\footnotetext{
${ }^{152}$ Georges Levasseur. Politica Criminal..., p. 156.

${ }^{153}$ Nilo Batista. Introdução crítica..., p. 35.

${ }^{154}$ Raymond Aron. Démocratie et totalitarisme. Paris: Gallimard, 1965, p. 21.
} 
ou de um governo, concernente a um problema ou à totalidade de problemas de uma coletividade" (política-ação) ${ }^{155}$.

De outro lado, o termo politics designa o domínio onde esses programas (policy) se rivalizam ou se compõem (política-domínio). Isso porque cada indivíduo ou grupo de indivíduo busca a implementação de seus interesses e objetivos, sendo que seus planos de ação podem ser parcialmente ou integralmente contraditórios ou compatíveis ${ }^{156}$.

Ademais, há uma diferença de termos quando se trata do conhecimento da política, da ciência que estuda esse fenômeno (política-conhecimento), e a política aplicada, isto é, do seu emprego na prática (política-realidade) ${ }^{157}$.

Por fim, o autor esclarece que a política pode ser entendida como condição de cooperação entre os homens - uma vez que essa cooperação implica uma autoridade e o modo de exercício dessa autoridade e a escolha de quem vai exercê-la é a essência da política - (política-geral) ou em sua relação com as instituições, como o Parlamento, os partidos e a sua administração (política-parcial) ${ }^{158}$.

Segundo Raymond Aron, são três, portanto, os equívocos em torno do emprego da palavra política: a política enquanto ação e a política enquanto domínio, na medida em que são ligadas uma a outra porque o domínio é o lugar onde se opõem os programas de ação; a política enquanto prática e a política enquanto conhecimento, porque o conhecimento é parte integrante da própria realidade; a política parcial e a política em sentindo geral, uma vez que a primeira conduz à segunda em razão do fato de que esse sistema parcial exerce sobre o conjunto da coletividade uma influência dominante ${ }^{159}$.

No presente estudo, voltado ao processo legislativo, interessa justamente a distinção entre política-ação e política-domínio. Isso porque a proposta é, em primeiro lugar, compreender em que medida a legislação votada e aprovada no Parlamento é fruto de uma escolha que tenha como pressuposto a análise das implicações sociais, políticas e econômicas de um problema, mediante o acesso à informação sobre as consequências da opção por cada uma das medidas possíveis, com vista a determinados fins, que considere

\footnotetext{
${ }^{155}$ Tradução livre de Raymond Aron. Démocratie et totalitarisme..., p. 21-22.

${ }^{156}$ Raymond Aron. Démocratie et totalitarisme..., p. 24-25.

${ }^{157}$ Raymond Aron. Démocratie et totalitarisme..., p. 23.

${ }^{158}$ Raymond Aron. Démocratie et totalitarisme..., p. 24-25.

${ }^{159}$ Raymond Aron. Démocratie et totalitarisme..., p. 24-25.
} 
os meios de aplicação e de avaliação, ou seja, se é resultado de um programa de ação, de um método de ação ou de ação proposta em razão de um problema social específico que se pretende resolver.

Em segundo lugar, a intenção é observar esse ponto não apenas como uma formulação teórica, mas decorrente da forma como os interesses e objetivos políticos que permeiam esse processo de tomada de decisões se rivalizam e se compõem, voltando-se, assim, para o sentido da política enquanto domínio.

Se o processo legislativo vem sendo concebido como uma das atribuições da política criminal, é preciso compreendê-lo como tal, incorporando na sua concepção as características inerentes à formulação de políticas públicas em geral, tais como a consideração dos recursos disponíveis para alcançar determinados fins, mediante o conhecimento prévio das implicações e possíveis resultados.

Além da tarefa de formulação da lei dever ser impulsionada por instrumentos de política criminal, é preciso compreender o que representa o espaço específico onde ocorre esse processo, isto é, diante da composição ou oposição de forças característica dos debates parlamentares, a proposta é verificar qual posição o direito poderia ocupar com o objetivo de participar da elaboração das leis.

É importante observar que não se trata de preconizar a introdução de questões políticas e sociais no direito, invadindo, assim, o espaço fechado que lhe foi atribuído pela dogmática jurídica, mas de propor aos juristas novos espaços de atuação, que favoreçam, inclusive, a formulação do seu objeto de estudo.

\section{Proposta de reformulação do papel da dogmática jurídica}

Além de observar como a dogmática jurídica se apropriou do conteúdo político do processo de elaboração de leis, transformando-o em um tema de direito positivo, a partir dos dogmas que o sustentam, é preciso compreender qual função lhe foi atribuída nessa análise, para, então, apresentar uma proposta de reformulação do seu papel. 
Conforme anteriormente analisado, a dogmática tende a reduzir a tarefa dos juristas à interpretação e sistematização dos preceitos legais, sendo que o positivismo jurídico contribuiu para que qualquer análise das regras jurídicas que não diga respeito ao direito posto seja atribuída a outras ciências, como a política e a sociologia.

Ainda que se admita o direito como um sistema normativo fechado, não permitindo a introdução de fatores externos no processo de análise e interpretação ${ }^{160}$, essa postura não impede que ele seja compreendido no âmbito de controvérsias políticas e de conflitos entre interesses sociais.

Segundo Dimitri Dimoulis, "quem adota essa perspectiva conflitual sobre a criação do direito questiona a ficção da existência de um legislador que cria normas 'de acordo com a sua vontade' ou, ideologicamente, 'de acordo com a vontade do povo', apresentando essas vontades como algo inexplicável, imprevisível e quase natural" ${ }^{161}$.

Sem abandonar os limites do positivismo jurídico, o autor defende que haja uma estrita separação entre a atividade de definição e de interpretação do direito e sua análise crítica em perspectiva política ${ }^{162}$.

Em sua opinião, "a teoria do direito não pode permanecer alheia ao estudo da política, da economia e da ideologia, como afirmam os partidários de uma teoria do direito supostamente pura e, na verdade, amputada. A reflexão do direito deve situar-se no centro do interesse do teórico do direito que deseja entender as determinações políticas do sistema jurídico" 163 .

Assim, se à dogmática ou doutrina jurídica cabe o estudo sistemático e crítico da regulamentação jurídica em vigor, como o "propósito essencial de fazer a partir dessa uma apresentação ordenada, um comentário mais aprofundado e racional, dando enfoque às relações harmoniosas entre seus diferentes componentes, mas denunciando, também, as

\footnotetext{
160 "Na perspectiva interna, o direito é um sistema normativo herme(neu)ticamente fechado. Isso ocorre não porque consideramos que determinado direito positivo seja 'bom', nem porque o sistema jurídico é imprescindível ao convívio social. Seguimos simplesmente a opção descritiva do juspositivismo, evitando a confusão entre as opções políticas pessoais do aplicador e seu trabalho de intérprete. Dessa forma, o intérprete se autolimita, reconhecendo que a interpretação não pode fingir que encontra uma clara vontade do legislador onde não há, nem confundir o juridicamente imposto como o razoável e o adequado" (Dimitri Dimoulis. Positivismo jurídico..., p. 160).

${ }^{161}$ Dimitri Dimoulis. Positivismo jurídico..., p. 160.

162 Dimitri Dimoulis. Positivismo jurídico..., p. 163.

${ }^{163}$ Dimitri Dimoulis. Positivismo jurídico..., p. 162.
} 
contradições irredutíveis, as lacunas, ambigüidades e outras imperfeições e sugerindo reformas e melhoramentos" ${ }^{164}$, propõe-se que as opiniões que resultem dessa atividade passem a se preocupar com o modo de elaboração dessas normas ou a forma de encaminhar essas críticas antes mesmo da aprovação da lei.

Considerando que não há uma determinação a priori das condutas sociais que devem ser reguladas pelo direito, é a relação entre os atores que participam do processo de elaboração das normas jurídicas que vai dizer o que deve ou não entrar no ordenamento, na medida em que uma lei não surge automaticamente, mas a partir de interações sociais concretas, em um processo político definido e instituído em determinada sociedade ${ }^{165}$.

Ocorre que a dogmática jurídica não se identifica como um desses atores, renegando a possibilidade de participar desse processo e colaborar com a construção de normas mais condizentes com os princípios e regras que estruturam o direito e, portanto, coerentes com o ordenamento jurídico como um todo.

Se a idéia de um legislador "racional" que capta os problemas sociais e propõe soluções jurídicas através da edição de normas, é uma ficção, utilizada para facilitar a interpretação e sistematização do direito, é preciso reconhecer que entre o surgimento de um problema social e a escolha de uma solução jurídica, há uma institucionalização, onde é possível observar a relação entre diferentes protagonistas, seus modos de atuar e os recursos que conseguem mobilizar para criar o direito ${ }^{166}$.

Assim, a aceitação de que "a criação da lei é uma obra humana cheia de imperfeições, coberta pelo mito da vontade geral" ${ }^{167}$ permite que o papel da dogmática jurídica seja reformulado, aproximando-a, assim, do processo de elaboração de normas pelo Parlamento.

Nesse sentido, considerando o campo jurídico um espaço de disputa entre diferentes atores, Enguéléguélé desenvolve o conceito de "comunidade epistêmica penal"

\footnotetext{
164 Tradução livre de Paul Amselek. Avant-propos. In Zenon Bankowski et al. La science de la législation. Paris: PUF, 1988, p. 5.

165 Philippe Robert. Essai de construction d'un paradigme penal. In Normes, normes juridiques, normes penales. Pour une sociologie de frontières, tomo II. Paris: L'Harmattan, 2000, p. 61.

${ }^{166}$ Philippe Robert. Essai de construction..., p. 67. Segundo Georges Ripert, falar de um direito dado é dizer que o legislador trabalha sobre uma matéria fria, que ele estuda a história, constata os fatos, raciocina e decide, quando, na realidade, tudo o que ele pode fazer é transigir habilmente dentro do jogo de forças opostas (Les forces créatrices du droit..., p. 83).

${ }^{167}$ Georges Ripert. Les forces créatrices du droit ..., p. 96.
} 
(communauté epistémiqué pénale) ${ }^{168}$ para designar as comunidades formadas por grupos que produzem uma reflexão doutrinária utilizada como elemento formulador de políticas públicas $^{169}$.

Essa rede de expertises se caracteriza pela adesão dos seus membros ao mesmo paradigma, isto é, às mesmas explicações causais dos problemas criminais (nível cognitivo), ao mesmo sistema de valores erigidos como referências normativas para a estratégia penal (nível normativo) e pela adoção do mesmo tipo de ação a ser aplicada em face da criminalidade (nível instrumental) ${ }^{170}$.

Uma comunidade epistêmica é, portanto, "uma rede de profissionais que dispõem de uma competência reconhecida em um domínio particular e que reivindicam com autoridade seu conhecimento político dentro desse domínio" ${ }^{171}$.

Segundo Enguéléguélé, a integração entre essas comunidades e os tomadores de decisões políticas é uma via de mão dupla, beneficiando ambos os lados: as contribuições das comunidades epistêmicas fornecem os elementos indispensáveis para o processo de tomada de decisão política, legitimando a decisão final ao contribuir com os aspectos técnicos das escolhas políticas; da mesma forma, ao produzir idéias que servem de suporte para as decisões políticas, as comunidades institucionalizam sua influência sobre os interesses e as escolhas de determinado Estado, reforçando sua visibilidade e prestígio social $^{172}$.

Conforme será analisado no próximo capítulo, diante da complexidade e dos riscos que envolvem as matérias a serem convertidas em proposições legislativas, os

\footnotetext{
${ }^{168}$ Segundo o autor, o conceito tem origem na análise das relações e cooperação internacionais, marcadas pela diminuição da capacidade de antecipação e de decisão dos atores encarregados da gestão internacional. As redes ou comunidades de especialistas funcionam, nesse contexto, como fornecedores de informação e redutores de incertezas, com o intuito de assegurar maior eficácia das decisões dos atores políticos. A demanda cada vez maior por informações faz com que se configure uma verdadeira disputa entre diferentes comunidades pelo monopólio das posições de conselheiros dos governantes (Stéphane Enguéléguélé. Les communautés épistémiques pénales et la production législative en matière criminelle. Droit et Société, n. 40, 1998, p. 567).

${ }^{169}$ Stéphane Enguéléguélé. Les communautés épistémiques pénales..., p. 566.

${ }^{170}$ Stéphane Enguéléguélé. Les communautés épistémiques pénales..., p. 569.

${ }^{171}$ Stéphane Enguéléguélé. Les communautés épistémiques pénales..., p. 568.

${ }^{172}$ Stéphane Enguéléguélé. Les communautés épistémiques pénales..., p. 578.
} 
órgãos encarregados da formulação legislativa procuram compartilhar a responsabilidade, aumentando os canais de participação desses especialistas ${ }^{173}$.

É claro que esses atores podem aproveitar o privilégio de opinar no processo legislativo, manipulando, ocultando ou desqualificando informações, com argumentos pretensamente técnicos ${ }^{174}$, entretanto, ainda que haja esse risco, é importante que os juristas modifiquem sua postura em relação à fase de elaboração normativa, reconhecendoa como um espaço de atuação, onde é possível apresentar argumentos e manifestar sua posição em relação às matérias em discussão.

Assim, se for possível pensar em um lugar de intersecção entre o direito e a política e os atores que deles participam, seria possível abordar o processo legislativo sob outra perspectiva, distinta da que vem sendo realizada pela dogmática jurídica.

Isso porque a participação no processo legislativo pressupõe o abandono da postura de neutralidade dogmática preconizada pelos juristas, que costumam assumir posição sobre o direito em um círculo fechado e reduzido, ao invés de submeter seus argumentos ao debate político, deixando claros os aspectos ideológicos e as linhas teóricas que sustentam as questões que defendem.

\footnotetext{
173 José Eduardo Campos de Oliveira Faria. Sociologia: Direito e conjuntura. São Paulo: Saraiva, 2010, p. 73.

${ }^{174}$ José Eduardo Campos de Oliveira Faria. Sociologia ..., p. 74. Segundo o autor, "o problema da abertura do processo de elaboração legislativa aos saberes especializados e determinados setores da sociedade está na sua ambigüidade. Em princípio, essa estratégia pode levar a um aprofundamento do regime democrático, pois expande os mecanismos participativos, alarga o alcance dos procedimentos consultivos e amplia o escopo dos procedimentos deliberativos, o que permitiria maior envolvimento do público na tomada de decisões vitais para a comunidade e possibilitaria formas mais avançadas de cidadania. No entanto, encerra o risco de sua 'captura' pelos setores sociais, econômicos e políticos interessados, que tenham que dispor de amplo controle da produção e circulação das informações específicas às suas respectivas áreas e campos de atuação, podendo assim resultar no retorno a velhas práticas decisórias de natureza corporativista ou, então, numa autoprodução do direito em circuito fechado e imune a controles externos" (José Eduardo Campos de Oliveira Faria. Sociologia..., p. 74-75).
} 


\section{II - AS TRANSFORMAÇÕES DO DIREITO E OS REFLEXOS NO PROCESSO LEGISLATIVO}

\section{Introdução}

Conforme analisado no capítulo anterior, prevalece entre os juristas uma concepção do direito como um conjunto de regras gerais, cuja origem se fundamenta em um processo de formação da lei como expressão da vontade geral, o que assegura a imparcialidade de seus comandos, e na existência de um legislador racional, o que garante a sistematicidade e a coerência de suas normas.

Diversos autores se dispõem a analisar as características desse modelo de direito, denominando-o de direito moderno ou clássico ${ }^{175}$, cujo traço principal é a centralização, nas mãos do Estado, da produção normativa, confiada a órgãos especializados, com competências bem definidas, assegurando-se sua observância através do exercício do monopólio da violência ${ }^{176}$.

Para Jacques Chevallier, essas características se contrapõem ao modelo anterior, do direito tradicional, que se relaciona diretamente com a religião ao buscar, na vontade divina, a autoridade da lei, além de se encontrar marcado pelo pluralismo, tendo em vista a multiplicidade de fontes do direito, típica do feudalismo ${ }^{177}$.

Segundo esse autor, é justamente no movimento de laicização do direito, que adquire autonomia, no reconhecimento do Estado como sua fonte exclusiva e, consequentemente, na imposição da supremacia estatal, que se começa a identificar uma nova configuração do direito, típica da modernidade ${ }^{178}$.

\footnotetext{
175 Nesse sentido, ver Charles-Albert Morand. Le droit néo-moderne des politiques publiques. Paris: L.G.D.J., 1999, p. 28 e Jacques Chevallier. Vers un droit post-moderne? Les transformations de la régulation juridique. Revue de droit public et de la science politique, n. 3, 1998, p. 665.

${ }_{176}$ Jacques Chevallier. Vers um droit post-moderne?..., p. 665.

177 Jacques Chevallier. Vers um droit post-moderne?..., p. 664.

178 Jacques Chevallier. Vers um droit post-moderne?..., p. 664-665. De acordo com Jacques Chevallier, o conceito de modernidade remete a um contexto sócio-histórico específico, marcado pela crença nas virtudes da razão, e não mais nas leis da natureza. O império da razão, segundo o autor, aparece acompanhado de uma série de outras crenças, que constituem os mitos inerentes à modernidade: a crença nas virtudes da ciência, que dota o homem de um domínio cada vez maior sobre a natureza; a fé no progresso, que assegura a
} 
Conforme afirma Charles-Albert Morand, "esse direito é uma síntese entre a concepção de direito do Estado de polícia, que vê o direito como um mandamento, uma força irresistível, e a concepção do Estado de direito democrático, que torna esse comando aceitável, pois fundado em regras gerais, admitidas porque emanadas pelo povo (democracia direta) ou por autoridades por ele eleitas (democracia indireta)" ${ }^{179}$.

A divisão do direito de acordo com certas características que predominam em determinada época e em razão da configuração política e econômica da sociedade é um recurso utilizado por esses autores para compreender transformações mais recentes, que têm tornado o direito mais flexível, complexo e adaptável, resultado de negociações que pressupõem a diversidade dos interesses em jogo ${ }^{180}$, conforme será observado nesse capítulo.

A presente análise pressupõe, portanto, que há uma relação entre o direito e a política capaz de marcar profundamente a concepção do direito que se quer estabelecer em determinada forma de Estado.

A justificativa para se afirmar essa relação advém do fato de que o Estado (i) detém o monopólio legítimo da violência, (ii) tem como uma das suas principais funções a manutenção da ordem pública, sendo o direito um dos instrumentos a disposição para a execução dessa tarefa, e (iii) centraliza a tarefa de elaboração de normas jurídicas, apresentada pela Declaração dos Direitos dos Homens e do Cidadão como atributo essencial da soberania. Nesse sentido, um problema verificado nos fundamentos do direito pode ser associado a um problema relacionado aos fundamentos do Estado ${ }^{181}$.

Ainda que apresentem uma série de dificuldades, conforme menciona Chevallier ${ }^{182}$, pois pressupõe generalizações e afinidades consideradas inexoráveis, mas

melhoria progressiva das condições de vida; a noção de que a história tem um sentido e que a razão deve progressivamente impor a sua lei; e, por fim, a ideia de que o indivíduo se encontra no centro do universo (Vers un droit post-moderne?..., p. 661).

${ }_{179}$ Tradução livre de Charles-Albert Morand. Le droit néo-moderne..., p. 28.

${ }^{180}$ Essas características são atribuídas, por Jacques Chevallier, ao modelo de direito que o autor denomina de pós-moderno (Vers um droit post-moderne?..., p. 671).

181 Marie-Hélène Galmard. État, société et loi pénale. Aix-en-Provence: Presses Universitaires d'AixMarseille, 2006, p. 15-16.

${ }^{182}$ Ao contrapor o direito clássico, típico das sociedades modernas, a um direito novo, reflexo da pósmodernidade, o autor menciona a dificuldade de estabelecer essas relações, não pela associação entre direito e sociedade, pois, em sua opinião, é evidente que o direito, enquanto produção social, deve evoluir em função das mutações sociais, mas pela análise histórica sobre a qual repousa. Segundo Chevallier, a idéia de entrada na era da pós-modernidade está, na verdade, cheia de equívocos, pois além de, do ponto de vista descritivo, 
que muitas vezes não se verificam na realidade de maneira linear, o aspecto interessante dessas análises é a possibilidade de entender e propor formas de ultrapassar os limites impostos pela separação rígida entre política e direito, preconizada pelos juristas, buscando a compreensão interdisciplinar desses fenômenos, mais condizente com a complexidade das sociedades contemporâneas.

Sob o aspecto das dificuldades que devem ser consideradas, é preciso lembrar, ainda, que qualquer relação entre formas de Estado e modelos de direito não passa de um reflexo imperfeito da realidade, pois, na prática, diversas estruturas de funcionamento e regulação da sociedade coexistem ao mesmo tempo. Além disso, dizer que alguns modelos se sucedem ao longo da história não significa afirmar que cada etapa ignore tudo o que existia antes $^{183}$.

Assim, a configuração do direito como um conjunto de regras marcadas pela sistematicidade, generalidade e estabilidade, por exemplo, não se restringe ao período em que se reconhece a conformação de um tipo de Estado definido como liberal, pois apesar dessas regras terem sido flexibilizadas para responder aos fenômenos sociais mais recentes, ainda é muito comum observar a fundamentação do direito em bases construídas nesse período.

Ao citar os modelos de Estado e formas de intervenção na sociedade que foram sistematizados por Charles-Albert Morand ${ }^{184}$, Maria Paula Dallari Bucci discorre que “evidentemente, não há um corte temporal separando nitidamente essas fases: o que há são técnicas de intervenção jurídica que vão sendo criadas e modificadas, a ponto de caracterizar novos padrões qualitativos da relação entre o Estado e a sociedade. Essas diferentes técnicas convivem no tempo, sem nunca ter chegado a afastar o paradigma da norma geral e abstrata, a qual, mesmo criticada e contestada, ainda permanece como o grande elemento de identidade do sistema jurídico. As diversas técnicas de intervenção são

atribuir certas tendências de evolução às sociedades contemporâneas, sob o aspecto normativo, coloca em evidência o desejo de reformulação do laço social, sem contar que a proclamação do surgimento da sociedade pós-moderna já a faz surgir pela magia do discurso (Jacques Chevallier. Vers un droit post-moderne?..., p. 660).

${ }^{183}$ Charles-Albert Morand. Le droit néo-moderne..., p. 17-18.

${ }^{184}$ Em sua análise, pra melhor compreender determinada realidade social ou jurídica, Charles-Albert Morand descreve tipos ideais de Estados e de direitos, relacionando, assim, o Estado liberal ao direito moderno; o Estado intervencionista ao direito da atividade de prestação de serviços públicos; o Estado propulsivo ao direito dos programas finalísticos; o Estado reflexivo ao direito dos programas relacionais; e o Estado incitador ao direito fundado nos atos persuasivos e normativos (Charles-Albert Morand. Le droit néomoderne..., p. 16). 
utilizadas ao mesmo tempo. E, mais do que isso, são utilizadas diferentemente segundo a atividade social em questão, fazendo conviver modos de ação do Estado liberal, do Estado intervencionista, do Estado propulsivo num mesmo espaço e tempo. O que ocorre é que determinadas atividades sociais são mais propícias a uma ou outra técnica" ${ }^{185}$.

Sob esse aspecto, François Ost afirma que atualmente se sobrepõem três figuras diferentes de Estado: o liberal, que continua a fornecer a gramática de base (conceitos e princípios fundamentais) do direito; o intervencionista, cujas instituições não foram desmanteladas, apesar do choque da mundialização-privatização das economias; e um terceiro tipo, que recebe diversas qualificações, mas que é marcado por um direito estruturado em redes, descentralizador, mais incentivador do que normativo ${ }^{186}$.

Considerando, portanto, a utilidade prática dessas associações, que servem para facilitar a compreensão das transformações vivenciadas pelas sociedades contemporâneas, é possível afirmar que certas características do Estado são capazes de levar à formação de um modelo de direito que corresponda aos valores e crenças nelas prevalecentes.

É diante dessa perspectiva que se pretende, no presente capítulo, analisar as transformações sociais e políticas que justificam a reformulação do modo de pensar o direito e a sua relação com o Estado, especialmente no processo de elaboração de normas jurídicas.

A proposta é observar como as transformações organizacionais e funcionais da política acabam por gerar uma necessidade de realizar certas modificações no direito, adotando-se um novo modelo mais adequado à nova realidade.

Nesse sentido, é importante considerar os vínculos entre Estado e direito, tendo como parâmetro uma concepção das regras jurídicas enquanto ferramentas de direção pública das condutas sociais à disposição do Estado, que não podem ser conhecidas

\footnotetext{
${ }^{185}$ Como exemplo, a autora cita que "isto explica o uso disseminado dos programas finalísticos nas áreas de direito urbanístico e ambiental, por exemplo, com grande difusão de instrumentos de planejamento, e a inadequação dessas técnicas em outras áreas, como a do direito da concorrência, em que o elemento das informações estratégicas das empresas é refratário à subordinação a programas públicos de transparência" (Maria Paula Dallari Bucci. Direito administrativo e políticas públicas. São Paulo: Saraiva, 2006, p. 246).

${ }^{186}$ François Ost. La régulation: des horloges et des nuages. In François Ost e Benoît Jadot (dir.). Élaborer la loi aujourd'hui, mission impossible? Bruxelles: Facultés Universitaires Saint-Louis, 1999, p. 17. Para o autor, ao contrário dos anteriores, esse último modelo cumula todas as inseguranças, pois enquanto o Estado liberal garantia certa segurança jurídica ao preço de uma forte insegurança econômica, o Estado intervencionista busca reduzir a insegurança econômica ao preço de maior insegurança jurídica.
} 
independentemente do exercício do poder público e do contexto específico de atos e relações sociais de autoridade no qual se insere.

Para facilitar essa tarefa, portanto, é preciso abandonar o aspecto transcendental do direito e compreendê-lo como resultado de um processo historicamente situado, limitado, reflexo de necessidades específicas e de interesses em conflito.

A partir da constatação de que a elaboração de normas jurídicas se configura como um processo complexo, onde participam diversos atores e do qual decorrem negociações e compromissos que sofrem a influência de interesses determinados, e não mais como o resultado da atuação de um legislador racional, é preciso repensar essa atividade não só mediante a influência da lógica das políticas públicas, como a partir de uma concepção da democracia que não se restringe ao exercício do direito de representação política.

Nesse sentido, pretende-se analisar, em primeiro lugar, o modelo de direito que se fundamenta em alguns dogmas, como a presunção de racionalidade do legislador e da imperatividade da norma jurídica, típicos de um ordenamento jurídico concebido por um Estado centralizador, para compreender, em segundo lugar, como as mudanças no papel do Estado, que se torna mais interventor, provocam a incorporação no direito de aspectos inovadores, associados às tarefas de construção e implementação de políticas públicas.

Essa mudança de concepção influencia, de forma direta, o processo legislativo. Considerando que o direito deve ser compreendido a partir da perspectiva de gestão pública, é preciso, além de obedecer a determinados fins e objetivos no processo de elaboração das normas, encontrar meios de ampliar o diálogo entre Estado e sociedade durante o exercício dessa tarefa.

Além disso, a intenção é observar como alguns estudiosos têm compreendido o processo de formulação de normas como um espaço de concretização da democracia, propondo a elaboração conjunta de normas, cujas escolhas e decisões pressupõem a participação de todos interessados, não só de representantes eleitos. 
Trata-se, em última instância, do alargamento do conceito de democracia, substituindo-se a idéia de adesão por obediência pela de adesão a partir da participação ${ }^{187}$, com o intuito de conferir maior legitimidade ao Estado.

Por fim, pretende-se observar como essas mudanças influenciam a forma de pensar e elaborar o direito penal, verificando-se em que medida sua formulação pode ser objeto de uma discussão entre diversos atores e pressupor a participação de todos os interessados.

\section{O modelo de direito do Estado liberal}

A concepção do Estado como titular do monopólio legítimo da violência, a partir da centralização do poder em suas mãos, encontra-se diretamente relacionada à impossibilidade de exercício arbitrário desse poder.

Nesse sentido, para assegurar que suas decisões respeitem os direitos e as liberdades individuais e não ultrapassem os limites por eles impostos, o Estado assume um forte vínculo com o direito, na medida em que passa a fundamentar sua atuação no princípio da legalidade, o que assegura, em última instância, sua legitimidade ${ }^{188}$.

É o direito, portanto, que vai diferenciar o emprego da força coatora do Estado do exercício arbitrário da violência. Para que isso ocorra, o Estado centraliza a produção das normas jurídicas, sendo a lei concebida como a única fonte do direito ${ }^{189}$.

\footnotetext{
${ }^{187}$ Jacques Commaille. L'esprit sociologique des lois..., p. 209.

188 "O problema da legitimidade nasce, justamente, quando o governo das comunidades antigas deixa de ser direto - nas quais os cidadãos governavam-se eles próprios - e passa a intermediário - como é o caso dos regimes representativos. Portanto, é a partir desse momento que surge a necessidade de um critério externo aos próprios governantes para a validação dos regimes políticos e seus ordenamentos, ou seja, a necessidade de algumas justificativas para a representatividade obtidas mediante a transferência de direitos até então considerados inalienáveis. (...) Em suma, a democracia é o regime dos sistemas abertos, ou seja, aqueles que procuram garantir a manutenção das regras do jogo, a sobrevivência dos textos constitucionais, a impessoalidade e o rodízio do poder, e a ação dos diferentes grupos sociais, sem a eliminação das partes descontentes e de maneira menos coercitiva possível" (José Eduardo Campos de Oliveira Faria. Poder e legitimidade..., p. 62).

${ }_{189}$ É importante esclarecer que não basta que o Estado centralize a produção das normas jurídicas para se afirmar que o emprego da violência não está ocorrendo de forma arbitrária, isto é, não basta que o Estado centralize a produção das regras, de forma a evitar uma multiplicidade de fontes normativas que impeça o alcance da ordem social, é preciso que o exercício da violência ocorra dentro dos parâmetros legais, ou seja, de acordo com as normas criadas a partir da centralização do poder regulamentador. Não é suficiente, portanto, que as normas sejam válidas se forem executadas de forma arbitrária pelo Estado.
} 
De fato, a fundamentação da atuação estatal em um poder juridicamente regulamentado é essencial para a consolidação da soberania, pois assegura a observância das regras impostas pelo Estado ${ }^{190}$.

Assim, ao lado da teoria da separação dos poderes e da noção de soberania estatal, a idéia de submissão do Estado aos ditames da lei completa o tripé de sustentação do Estado liberal de direito.

É importante compreender como o modelo de direito adotado nesse contexto desvirtua a noção de legitimidade ao tratá-la como sinônimo de legalidade, "destacando assim a 'estatização' das fontes do direito e a coerência lógico-formal do sistema normativo" 191 .

Segundo José Eduardo Faria, a legitimidade pode ser compreendida como a "adesão espontânea a uma ordem", o conjunto de valores que asseguram que o ordenamento jurídico seja respeitado sem o emprego da força. A legalidade, de outro lado, relaciona-se com a ideia de regras do jogo e está sempre associada a procedimentos formais ${ }^{192}$.

Assim, enquanto a legalidade é impositiva, "exigindo o cumprimento irrestrito, independente da opinião que os cidadãos dela possam ter, sob pena de sanções", a legitimidade "diz respeito ao título do exercício do poder, ao fundamento das decisões políticas e comandos jurídicos" ${ }^{193}$.

\footnotetext{
${ }^{190}$ De acordo com José Eduardo Faria, "soberania e positividade são dois conceitos que se exigem mutuamente: a soberania é o poder originário de declarar, em última instância, a positividade do direito, enquanto positivo é o direito posto e garantido pelo poder soberano do Estado" (Poder e legitimidade..., p. 20).

${ }^{191}$ José Eduardo Campos de Oliveira Faria. Verbete legitimidade. In Marco Aurélio Nogueira (coord.). Dicionário de Políticas Públicas. São Paulo: Unesp/Fundap, no prelo.

${ }^{192}$ José Eduardo Campos de Oliveira Faria. Verbete legitimidade..., [s.p.]. O autor afirma que a legalidade "envolve procedimentos individuais, que propiciam a formalização dos acordos de vontades por cidadãos livres - como é o caso dos contratos, cuja função é garantir as condições acordadas entre as partes. Ela também envolve procedimentos políticos, como as regras do jogo eleitoral e da representação democrática, assegurando participação ampla, mandatos populares, o governo da maioria e a alternância no poder. Juntos, esses procedimentos disseminam certeza jurídica, propiciam calculabilidade econômica, dão às instituições a flexibilidade para neutralizar tensões, estabilizam as relações sociais e geram padrões de normalidade. Eles dão valor jurídico a atos concretos da vida cotidiana. Mas, quais são os valores políticos, econômicos, culturais ou ideológicos subjacentes a esse valor jurídico? Em que bases éticas ou morais a legalidade se sustenta? O que leva um cidadão a acatar de modo voluntário a ordem de um governante ou de um legislador, sem que este precise recorrer a mecanismos de violência? Esse é o campo temático da legitimidade".

193 José Eduardo Campos de Oliveira Faria. Verbete legitimidade..., [s.p.].
} 
A partir da monopolização da violência pelo Estado, o foco é colocado no modo como essa violência é utilizada, distinguindo-se seu exercício arbitrário, não submetido a regras prévias, do seu emprego discricionário, regulado e delimitado por normas que estabelecem uma margem de atuação ${ }^{194}$.

Entretanto, como explica José Eduardo Faria, a visão positivista do direito compreende essa arbitrariedade como ilegítima e a legalidade, por neutralizar o arbítrio, como legítima. O Estado funde-se ao direito porque, caso contrário, seria apenas violência ou força, e o direito, nesse contexto, encontra-se reduzido à observância de normas sancionadoras articuladas por critérios lógico-formais ${ }^{195}$.

É justamente pela desvinculação teórica com a política que o direito exerce a função de legitimação da atuação estatal. Para assegurar o respeito às regras emanadas pelo Estado, a lei se reveste de uma série de atributos, a começar pela ideia de que o exercício da função de legislar não é resultado de opções arbitrárias, mas reflexo da atividade de representantes democraticamente eleitos, capazes de identificar quais são os interesses gerais dos cidadãos ${ }^{196}$.

Nesse sentido, o direito só pode cumprir a função simbólica que lhe foi atribuída pela política se forem transcendidos seus modos de elaboração, ocultadas as condições de sua produção, apagados os traços de sua genealogia política ${ }^{197}$.

Essa opção faz com que a escolha política de uma entre diversas condutas sociais e da forma como regulamentá-las, com o intuito de editar uma norma jurídica, seja revestida de legitimidade, isto é, a partir da crença num legislador soberano e racional, capaz de identificar a vontade geral, não se cogita a possibilidade de uma norma ser fruto de uma decisão política, revestindo-se, eventualmente, de autoritarismo, pois adotada

\footnotetext{
${ }^{194}$ José Eduardo Campos de Oliveira Faria. Verbete legitimidade..., [s.p.].

195 José Eduardo Campos de Oliveira Faria. Verbete legitimidade..., [s.p.]. Segundo o autor, "no entanto, a violência legal não é legítima apenas pelo fato de ter seu uso disciplinado por normas jurídicas. Esse fator institucional - a vinculação do exercício da violência a uma lei - por si só não basta. Ele pode ser condição necessária, mas não é condição suficiente. O positivismo jurídico apresenta limites. Por exemplo, o que dizer acerca dos casos em que facções totalitárias se valem de procedimentos democráticos para ascender ao poder e exercê-lo com o objetivo de suprimir garantias fundamentais e liberdades públicas, de substituir a democracia por um regime fechado - a exemplo do que ocorreu com o nazismo? Nesse sentido, a história política contemporânea tem mostrado que a linha divisória existente entre a racionalidade do direito e a paixão política não costuma ser nítida nem, muito menos, rígida. E a aplicação das leis também não é apartada da realidade econômica ou política, dos efeitos que gera no meio social e nas expectativas de justiça dos cidadãos".

${ }^{196}$ Marie-Hélène Galmard. État, société et loi pénale..., p. 24-25.

${ }^{197}$ Jacques Chevallier. L'Etat de droit..., p. 60.
} 
oportunamente em função de interesses individuais, o que garantiria, em última instância, o exercício do poder.

Ao lado da compreensão da lei como expressão da vontade geral, é preciso, ainda, garantir a imparcialidade dos comandos editados pelo legislador e a sua aplicação a todos, sem distinção. Assim, para que possa ser amplamente compreendida, a lei deve ser clara, e para assegurar a previsibilidade das conseqüências impostas às condutas que violam as normas, deve ser permanente. Dessa forma, garante-se maior estabilidade às relações, o que, a longo prazo, também assegura o exercício da soberania estatal.

Como resultado dessas preocupações, aparece "um direito autônomo ${ }^{198}$, formado por regras gerais e abstratas, aplicáveis de maneira dedutiva por silogismo jurídico; um direito hierarquizado e organizado de maneira sistemática; enfim, um direito legitimado, pelo menos em última instância, por instituições democráticas" 199 .

Assim, o direito se apresenta como uma ordem unitária e coerente, formada por normas que se relacionam entre si hierarquicamente, por meio de princípios comuns que contribuem para a solução das antinomias, aumentando a coerência interna do ordenamento jurídico ${ }^{200}$.

Além disso, o direito apreende a realidade social por meio de conceitos abstratos, reagrupados em categorias amplas que facilitam a compreensão e a solução de casos concretos a partir de regras gerais. Por fim, para assegurar que as conseqüencias das condutas sociais sejam previsíveis, as normas são elaboradas para durar, adquirindo certa permanência $^{201}$.

Dessa forma, a concepção do direito como mecanismo de institucionalização do poder, cuja formalização produz universalização e assegura a previsibilidade dos

\footnotetext{
${ }^{198}$ Charles-Albert Morand. Le droit néo-moderne..., p. 47-48. Segundo o autor, essa autonomia representa a tentativa de isolamento do direito em relação a outros sistemas normativos, que atingiu o seu apogeu na teoria pura do direito, desenvolvida por Hans Kelsen, tendo em vista sua proposta de separação radical entre o direito e a política.

${ }^{199}$ Tradução livre de Charles-Albert Morand. Le droit néo-moderne..., p. 28.

${ }^{200}$ Jacques Chevallier. Vers un droit post-moderne?..., p. 665.

${ }^{201}$ Jacques Chevallier. Vers un droit post-moderne?..., p. 665-666.
} 
comportamentos, é fundamental para a manutenção da crença na capacidade estatal de resolver os conflitos sociais ${ }^{202}$.

Nesse modelo, atrelado à concepção do Estado de direito, a legalidade funciona como a base do processo de construção da legitimidade estatal ${ }^{203}$, isto é, a lei, fonte e condição de legitimidade do poder, assume um papel absoluto e inquestionável, operando independentemente de qualquer fundamentação real ${ }^{204}$. Conforme já mencionado, a contingência política é substituída pela permanência e estabilidade do direito.

De acordo com Jacques Chevallier, "o Estado de direito implica em uma confiança absoluta no direito, na crença nas virtudes da dogmática jurídica para atingir determinados objetivos e fazer prevalecer os valores aos quais se está ligado: é pela transformação em direitos subjetivos que serão preservadas as liberdades individuais; é pela proclamação da soberania nacional que será garantido o princípio democrático; é pela afirmação da liberdade de comércio e de indústria que se protege a sociedade civil dos riscos de ingerência estatal" 205.

Dessa forma, a compreensão do direito como expressão da vontade geral, o que assegura a imparcialidade de seus comandos, e a observância de um processo democrático de formação da lei, o que garante a obediência, constituem os pilares de sustentação da legitimidade do direito, no âmbito de sua formação, e, consequentemente, da política.

Entretanto, diversas críticas se dirigem a esse modelo de regulamentação da sociedade. Segundo Jacques Chevallier, a laicização não foi capaz de fazer desaparecer uma dimensão transcendental do direito ao livrá-lo do viés mágico ou religioso que o envolvia nas sociedades tradicionais, pois a autoridade que se atribui a ele advém, da mesma forma, de um sujeito anônimo, inatingível e misterioso, de onde provém a lei ${ }^{206}$.

\footnotetext{
${ }^{202}$ Do ponto de vista do positivismo jurídico, o Estado, na realidade, se vale do direito para encerrar os conflitos sociais. Não importa, portanto, se a solução alcançada foi a mais justa ou adequada, mas sim que alguma solução tenha sido alcançada mediante a observância de procedimentos pré-estabelecidos.

${ }^{203}$ É importante notar que a crítica formulada nesse ponto é dirigida a uma concepção extremada da legalidade, que desvincula a lei de qualquer relação com a realidade, além de concebê-la como fonte e condição de toda legitimidade, de forma absoluta. Não desconsidera, portanto, que o princípio da legalidade é a base do processo de construção da legitimidade, conforme estabelece Max Weber, ao explicar o conceito de poder nas sociedades modernas.

${ }^{204}$ Jacques Commaille et Pierre Lascoumes. La production gouvernementale du droit. France, Mission de Recherche Droit et Justice, 1995, p. 11.

${ }^{205}$ Tradução livre de Jacques Chevallier. L'Etat de droit..., p. 59.

${ }^{206}$ Jacques Chevallier. Vers un droit post-moderne?..., p. 666.
} 
Para Jacques Chevallier, a sociedade moderna repousa em uma confiança absoluta no direito, que conduz ao fetichismo da regra: a norma jurídica tende a substituir a realidade, capaz de fazer acontecer o que ela anuncia, pois a passagem pela forma jurídica constitui-se como garantia máxima de que as relações regulamentadas encontram-se estabilizadas $^{207}$.

Ainda que esse modelo de direito, do ponto de vista da sua função de delimitação do arbítrio estatal e da proteção dos direitos fundamentais dos indivíduos, não deva ser completamente abandonado, por ter como base o respeito à liberdade e a proteção da igualdade e da dignidade humana, assegurado mediante a observância de procedimentos formais e previamente estabelecidos, diante dessas críticas, torna-se importante reformular sua estrutura ${ }^{208}$, de modo a superar os dogmas que o sustentam e adaptá-lo aos novos papéis atribuídos ao Estado.

É nesse sentido que se pretende analisar, ao longo do presente capítulo, as mudanças sociais e políticas que têm demandado a reformulação de alguns aspectos do direito, especialmente do modelo formulado pelo positivismo jurídico, cuja manutenção, ainda que se justifique em relação a alguns aspectos, como já mencionado, deve ser revista.

\section{O modelo de direito do Estado intervencionista}

A aproximação entre o direito e a política implica numa mudança na forma de compreender o papel exercido pelo direito na tarefa de regulamentação das condutas sociais.

Na medida em que se questiona como o processo de elaboração das leis pode ser dissociado da vontade política que o impulsiona, percebe-se que funções governamentais desse tipo não podem ser concebidas como um exercício dedutivo de

\footnotetext{
${ }^{207}$ Jacques Chevallier. Vers un droit post-moderne?..., p. 668.

${ }^{208}$ Ao tratar das relações entre a sociedade civil e o Estado nas sociedades contemporâneas, Marie-Hélène Galmard ilustra bem a posição de diferentes teóricos franceses sobre a pertinência desse modelo teórico, identificando duas posturas diversas: de um lado, alguns autores, como Goyard-Fabre, entendem que esse modelo de direito, ainda que necessite algumas correções, é, ainda, um modelo atual; de outro lado, alguns autores, como Arnaud, vislumbram uma distorção, que pode ser traduzida em termos de ruptura ou de continuidade. Para ele, diante da irrupção de novos atores, o direito responde com fundamentos filosóficos obsoletos (Marie-Hélène Galmard. État, société et loi pénale..., p. 24-25).
} 
aplicação de regras gerais ${ }^{209}$, mas apenas a partir da compreensão de quem são os atores envolvidos e de quais objetivos eles pretendem alcançar com a regulamentação de determinado tema.

Essa concepção admite que o direito funciona muito mais como um instrumento de gestão pública à disposição do Estado na tarefa de orientação das condutas sociais ${ }^{210}$ do que como um mecanismo de legitimação a priori da atividade estatal.

A mudança na forma de compreender o direito está associada às transformações do papel do Estado, que deixa de ser concebido de forma centralizadora, a partir da imposição de condutas aos indivíduos, e passa a ser visto como mais um parceiro na construção de políticas públicas.

Assim, conforme ressalta Charles-Albert Morand, a reformulação do papel do Estado a partir da crescente importância atribuída a sua função de gestor de políticas públicas é capaz de produzir uma mudança radical nas estruturas jurídicas ${ }^{211}$.

Essa mudança tem sido identificada, por alguns autores, com o advento da concepção do Estado de bem-estar social ${ }^{212}$, marcado pelo crescente intervencionismo na esfera individual com o intuito de assegurar a igualdade material entre os cidadãos, utilizando o direito, portanto, como instrumento de promoção dos direitos sociais, econômicos e culturais.

$\mathrm{Na}$ medida em que o Estado pretende agir sobre diversos setores, cujos interesses encontravam-se restritos à esfera particular, busca orientá-los em um sentido mais compatível com o interesse coletivo e se vale do direito para ampliar sua área de atuação com o intuito de abranger tarefas relacionadas aos novos fins econômicos e sociais que lhe são atribuídos.

Se no modelo de Estado liberal há uma divisão evidente entre o público e o privado, garantida por meio do respeito à legalidade, pois ao indivíduo é permitido fazer

\footnotetext{
${ }^{209}$ Charles-Albert Morand. Le droit néo-moderne..., p. 30.

${ }^{210}$ Jacques Commaille. L'esprit sociologique des lois..., p. 35.

211 Charles-Albert Morand. Le droit néo-moderne..., p. 13.

212 Jacques Chevallier. Vers un droit post-moderne?..., p. 668 e Jacques Commaille et Pierre Lascoumes. La production gouvernementale du droit...., p. 25.
} 
tudo o que não for proibido em lei, começa a aparecer uma preocupação com a efetivação de direitos e a implementação real de programas que assegurem essa necessidade.

Diante das tarefas de planejamento e execução de políticas públicas, o direito pode ser assimilado como um entrave burocrático ao livre jogo entre os atores que participam dessas políticas ou se inserir nesse jogo, como mais um instrumento à disposição do Estado para implementação de reformas e políticas inovadoras.

No segundo caso, conforme afirma Patrice Duran, o direito se apresenta como uma moldura para a gestão de políticas públicas na medida em que cabe a ele desenhar as instituições, distribuir tarefas e papéis, repartir autoridade, estruturar as possibilidades de controle e de proteção. $\mathrm{O}$ direito funciona, portanto, como um instrumento à disposição do Estado para a realização de objetivos específicos de políticas públicas ${ }^{213}$.

Dessa forma, ao adotar a segunda postura, o direito se torna, mais uma vez, uma das principais expressões da regulação estatal ${ }^{214}$. Entretanto, nesse contexto de afirmação material de direitos sociais, deixa de ter valor em si, mas apenas em função dos resultados que permite obter ${ }^{215}$, isto é, não basta que os direitos dos cidadãos estejam previstos na lei, é preciso assegurar que eles sejam alcançados de fato.

Se antes o direito não buscava atingir finalidades precisas, mas apenas estabelecer as regras do jogo e deixar aos atores a preocupação de perseguir seus próprios objetivos, no momento em que passa a incorporar preocupações de políticas públicas, isso muda ${ }^{216}$.

As leis não são mais pensadas como a afirmação de valores ao qual a realidade deve se conformar, mas como instrumento de transformação da realidade. A perspectiva se torna, portanto, abertamente instrumental, tratando-se menos de impor um modelo a priori do que adaptar um programa de ação a uma conjuntura plural e cambiante ${ }^{217}$.

\footnotetext{
${ }^{213}$ Patrice Duran. Piloter l'action publique, avec ou sans le droit? Politiques et management public, v. 11, n. 4, dec. 1993, p. 11.

${ }^{214}$ Patrice Duran. Piloter l'action publique..., p. 3.

215 Jacques Chevallier. La juridicisation des precepts manageriaux. Politiques et management public, v. 11, n. 4, dec. 1993, p. 128.

${ }^{216}$ Charles-Albert Morand. Le droit néo-moderne..., p. 46.

${ }^{217}$ François Ost. La régulation: des horloges et des nuages..., p. 23.
} 
Assim, ainda que o direito não deixe de ser pensado como um conjunto coerente de regras, mutuamente compatíveis, regidas pelo princípio fundamental da nãocontradição, pois tende a manter a estrutura que lhe dá sustentação, essa sistematicidade não é mais presumida, devendo ser permanentemente conquistada ${ }^{218}$.

Isso porque as regras do direito, que até então vinham sendo avaliadas apenas quanto a sua validade e na relação entre as normas internas, e, ainda, mediante a observância de procedimentos formais, se vêem interpeladas do ponto de vista dos seus efeitos sociais ${ }^{219}$. A legitimidade não é mais adquirida de pleno direito, mas em razão da pertinência das ações realizadas ${ }^{220}$.

A eficácia do direito passa a depender efetivamente do grau de aceitação e receptividade das normas, submetendo-se à análise da aptidão de certos instrumentos previstos em lei responderem às expectativas de seus destinatários ${ }^{221}$.

O modelo de direito do Estado intervencionista, portanto, contribuiu muito para o surgimento de uma preocupação com os efeitos sociais das normas e sua aplicação na realidade, tendo em vista a necessidade de implementar políticas sociais mais efetivas.

De acordo com Maria Paula Dallari Bucci, mesmo que a forma de Estado intervencionista tenha se exaurido, como a noção de política pública é uma criação desse tipo de Estado, ainda é possível falar em implementação de políticas públicas porque seu legado é justamente a concepção de Estado social de direito, que se consagrou nas Constituições do século $\mathrm{XX}^{222}$.

Segundo a autora "a noção de política pública é válida no esquema conceitual do Estado social de direito, que absorve algumas das figuras criadas com o Estado de bemestar, dando a elas um novo sentido, agora não mais de intervenção sobre a atividade privada, mas de diretriz geral, tanto para a ação de indivíduos e organizações, como do próprio Estado" 223.

\footnotetext{
218 Jacques Chevallier. L'État post-moderne..., p. 146.

${ }^{219}$ Pierre Lascoumes. Normes juridiques et mise en oeuvre des politiques publiques. L'année sociologique, 40, 1990, p. 49.

${ }^{220}$ Jacques Chevallier. Vers un droit post-moderne?..., p. 669.

${ }^{221}$ Jacques Chevallier. La juridicisation des precepts manageriaux..., p. 115.

${ }_{222}^{22}$ Maria Paula Dallari Bucci. Direito administrativo..., p. 245-247.

${ }^{223}$ Maria Paula Dallari Bucci. Direito administrativo..., p. 247.
} 
Assim, ainda que outros modelos de Estado tenham sucedido os que foram até aqui examinados, é importante resguardá-los em razão das contribuições positivas que trouxeram à forma como o direito é pensado, mesmo após terem sofrido transformações.

De um lado, o modelo de direito do Estado liberal afirmou a importância da legalidade para afastar o arbítrio estatal e ordenar a vida social. De outro, o modelo do Estado intervencionista consolidou a importância das políticas públicas como instrumento de implementação de direitos e mudança social.

Em razão dessas questões, que auxiliam a compreensão da proposta desse trabalho, voltada a um campo específico do direito, esses dois modelos mereceram destaque, entretanto, é preciso dizer, antes de avançar, que a eles se seguiram outros, relacionados às mudanças políticas e econômicas que vem sendo vivenciadas pela sociedade, especialmente no final do século XX e início do século XXI.

José Eduardo Faria, por exemplo, ao analisar o impacto do fenômeno da globalização econômica no direito ${ }^{224}$, diferencia o Estado schumpeteriano do Estado keynesiano, afirmando que os novos atributos e funções do primeiro não podem ser executados por uma estrutura de poder centralizada, com a concentração de capacidades operacionais típicas do segundo ${ }^{225}$.

${ }^{224}$ Reconhecendo que a globalização é um processo multicausal, multidimensional, multitemporal e multicêntrico, o autor identifica cinco consequências do que chama de 'reestruturação do capitalismo', por ela propiciada: 1) a velocidade e a intensidade do desenvolvimento científico, o poder político-normativo propiciado pelas expertises e habilidades práticas decorrentes da expansão da tecnologia e a comoditização de conhecimentos especializados cada vez mais voltados a resultados de curto prazo e dividendos imediatos; 2) a redução da margem de autonomia dos governos nacionais na formulação, implementação e execução de políticas macroeconômicas, de um modo geral, e nas políticas monetária e cambial, de modo específico; 3) a crescente diferenciação da economia em sistemas e subsistemas cada vez mais especializados; 4) o fenômeno de 'relocalização industrial' propiciado pelo advento de técnicas mais informatizadas e flexíveis de produção, também conhecidas como técnicas pós-fordistas, e a tendência de crescimento dos tamanhos das empresas transnacionais relativamente ao peso econômico e político dos países; 5) o empalidecimento da ideia de Estado-nação, em decorrência de uma crescente e complexa trama de relações motivadas por interesses distintos entre organismos multilaterais, conglomerados mundiais, centros de expertise e organizações nãogovernamentais (José Eduardo Campos de Oliveira Faria. Sociologia..., p. 12-13).

${ }_{225}$ De acordo com o autor, as estratégias keynesianas, típicas do Estado de bem-estar social, "voltadas à implementação de programas de pleno emprego, acordos corporativos que vinculam salário e inflação, protecionismo das indústrias nacionais, investimento na infra-estrutura para ampliação da produção de bens duráveis e crescimento baseado quer na produção em massa quer no consumo em massa, são acusadas de distorcer preços, minar a competitividade das empresas e inibir a criatividade necessária ao desenvolvimento científico-tecnológico, além de provocar desequilíbrios macroeconômicos", enquanto as estratégias schumpeterianas "são basicamente orientadas ao fomento da competitividade e ao estímulo à inovação, em busca de novas tecnologias, novas formas de trabalho, novos produtos, novos modelos de negócios e novos padrões de organização e gestão" (José Eduardo Campos de Oliveira Faria. Sociologia..., p. 53-54). 
Nesse contexto, "as tradicionais normas abstratas, gerais e impessoais" vão sendo substituídas por "normas cada vez mais particularizantes, específicas e finalísticas", assumindo um caráter mais procedimental, sob a forma de princípios e recomendações, com o intuito de viabilizar soluções a uma realidade cada vez mais complexa e cambiante, e não mais de regular de forma direta as condutas sociais ${ }^{226}$.

Além disso, diante dessa crescente complexidade e da incapacidade do Estado de responder a essa realidade com os instrumentos jurídicos tradicionais, surgem novas fontes de produção normativa, tanto no âmbito supranacional, quanto nos espaços infraestatais $^{227}$.

A pluralidade de fontes normativas, aliada ao crescente aumento da complexidade social faz com que se multipliquem as esferas de decisão, revelando-se o desafio de enfrentar essa realidade com os instrumentos típicos dos modelos do Estado liberal e do Estado intervencionista.

Ao analisar o Estado que denomina de regulador, Jean-Paul Rocha coloca em evidência a dificuldade da doutrina jurídica, especialmente em razão de uma visão tradicional do princípio da separação de poderes, em lidar com os órgãos reguladores financeiros, tais como o Conselho Monetário Nacional e o Banco Central do Brasil, que criam direito, incumbem-se de sua interpretação e aplicação e formulam políticas públicas, desempenhando, assim, as três funções clássicas do Estado ${ }^{228}$.

Percebe-se, portanto, que o direito vem sendo remodelado de acordo com as novas funções assumidas pelo Estado, em razão das transformações vivenciadas pela sociedade em áreas como a economia, tecnologia e informática.

No âmbito do direito penal, por exemplo, autores como Pierpaolo Bottini e Marta Machado têm analisado as mudanças nos institutos jurídicos tal como concebidos

\footnotetext{
${ }^{226}$ José Eduardo Campos de Oliveira Faria. Sociologia..., p. 56 e p. 76.

${ }^{227}$ José Eduardo Campos de Oliveira Faria. Sociologia..., p. 39.

${ }^{228}$ Segundo o autor, o princípio da separação de poderes serve de couraça a um pensamento jurídico-político que reluta em aceitar a constitucionalidade das normas editadas por órgãos do Poder Executivo (Jean-Paul Veiga da Rocha. A capacidade normativa de conjuntura no direito econômico: o déficit democrático da regulação financeira. Tese de Doutorado, Faculdade de Direito da Universidade de São Paulo, 2004, p. 11).
} 
pelo positivismo clássico, em razão dos riscos advindos do desenvolvimento econômico e das inovações tecnológicas ${ }^{229}$.

Inclusive, grande parte dessas propostas de mudança volta-se à ampliação da esfera de atuação estatal, pois diante da presença de novas formas de criminalidade, de grande escala, e do aumento das incertezas diante dos avanços tecnológicos vivenciados pela sociedade ${ }^{230}$, cada vez mais caracterizada pela pluralidade, a tendência é justamente recorrer ao Estado e propor a criminalização de novas condutas, o incremento dos tipos penais já existentes, a redefinição das regras de imputação da conduta criminosa, o recurso frequente aos tipos penais indeterminados, normas penais em branco, crimes culposos e crimes de perigo ${ }^{231}$, e o esvaziamento das garantias processuais que protegem os indivíduos do arbítrio estatal ${ }^{232}$.

229 Sobre o tema, ver Marta Rodriguez de Assis Machado. Sociedade do risco e Direito Penal: uma avaliação de novas tendências político-criminais. São Paulo: IBCCRIM (Monografias/34), 2005 e Pierpaolo Cruz Bottini. Crimes de perigo abstrato e princípio da precaução na sociedade de risco. São Paulo: Revista dos Tribunais, 2007.

${ }^{230}$ De acordo com Pierpaolo Bottini, que trata da chamada sociedade do risco, "a intensificação da sensação de insegurança, pela democratização dos riscos e pela distorção em sua percepção, acirra o discurso pela restrição de atividades arriscadas que, ao mesmo tempo, são imprescindíveis para o desenvolvimento econômico dentro do atual modelo de livre concorrência. A expectativa econômica de inovação, que faz funcionar o sistema atual de produção e consumo, abala a expectativa de segurança, e coloca em crise a estrutura deste mesmo modelo. Este embate discursivo antagônico, paradoxal e autofágico tem conseqüências em todos os níveis de organização social, com potencial para desestruturar sua base estável e abalar os mecanismos de controle normativo, dentre os quais a produção legislativa" (Pierpaolo Cruz Bottini. O princípio da proporcionalidade na produção legislativa brasileira e seu controle judicial. Revista Brasileira de Ciências Criminais, ano 18, n. 85, jul.-ago. 2010, p. 277).

231 Segundo Pierpaolo Bottini, em uma sociedade sujeita aos riscos advindos do desenvolvimento tecnológico, industrial e informático, a dificuldade de distinguir os comportamentos que ameaçam a sociedade e os que se mostram inócuos, leva à proliferação de crimes culposos, em razão de sua "descrição típica estar restrita ao resultado", das normas penais em branco, "nas quais se relega à autoridade administrativa a complementação dos elementos típicos", e dos tipos indeterminados, "nos quais a complementação normativa será realizada pelo magistrado". Além disso, com relação ao resultado da conduta criminosa, em razão da dificuldade de identificá-lo, recorre-se aos crimes de perigo (O princípio da proporcionalidade..., p. 283-284).

232 É nesse sentido que José Eduardo Faria afirma que "enquanto nos demais ramos do direito positivo vivese uma fase de desregulamentação, deslegalização e desconstitucionalização, no âmbito do direito penal verifica-se justamente o inverso. Ou seja: sua instrumentalização com vistas a fins claramente políticos, mediante a criminalização de várias atividades e comportamentos em inúmeros setores da vida social; a eliminação dos marcos mínimos e máximos na imposição de penas de privação de liberdade, para aumentálas indiscriminadamente; a relativização dos princípios da legalidade, da tipicidade, da lesividade e da imputação de responsabilidade individual, por meio da utilização de regras com conceitos deliberadamente indeterminados e ambíguos, ampliando extraordinariamente a discricionariedade das autoridades policiais e, com isso, permitindo-lhes invadir esferas de responsabilidade do Poder Judiciário; e, por fim, a redução de determinadas garantias processuais, pela substituição de procedimentos acusatórios por mecanismos com feições inquisitórias, das quais o melhor exemplo é o progressivo desfiguramento do princípio da presunção de inocência e a subseqüente possibilidade de inversão do ônus da prova, passando-se a considerar culpado quem não provar sua inocência. No limite, o que se tem aqui é uma espécie de direito penal 'máximo', cujo ideia central é que nenhum culpado permaneça impune à custa da incerteza de que algum inocente possa ser punido (ao passo que o direito penal 'mínimo' propõe a construção de um sistema destinado a fazer com que 
A proposta, entretanto, não é examinar esse fenômeno com mais profundidade, limitando-se a análise aos dois modelos mencionados, na medida em que se revelam suficientes para discutir as características do direito que vem sendo questionadas no presente trabalho.

\section{As transformações do direito}

Independentemente da associação das mudanças acima verificadas com (i) as inovações introduzidas pelo conceito de gestão de políticas públicas, (ii) o advento de um Estado mais interventor, que assume a tarefa de promoção de direitos sociais, ou (iii) as transformações vivenciadas pela sociedade, que se torna mais complexa em face dos avanços tecnológicos e aumenta a demanda por novas áreas de regulação, a tendência que se verifica é de expansão do direito.

Essa expansão contribui para a proliferação anárquica das normas, o que afeta a coesão e perturba a estrutura do direito. $O$ direito não se apresenta mais como um conjunto de regras gerais, hierárquicas e articuladas entre si, mas como um mosaico de textos múltiplos, diversificados, emaranhados, que visam se aproximar mais da realidade social, levando à necessidade de detalhamento cada vez maior dos textos e, portanto, tornando-os mais propícios a cair em desuso diante de novas transformações sociais, renovando-se, assim, o ciclo de produção de normas, que aumenta em ritmo incessante ${ }^{233}$.

Conforme aponta Jacques Chevallier, a estabilidade da regra jurídica está relacionada à sua generalidade. No momento em que a lei se torna mais precisa e detalhada, a tendência é que sofra um golpe muito maior de caducidade, artificialidade e obsolescimento. Nesse contexto, o direito é chamado a se renovar num ritmo cada vez mais rápido: assim que um texto é adotado, já há um esforço para corrigir suas imperfeições e remediar suas lacunas ${ }^{234}$.

nenhum inocente seja unido à custa de que algum culpado não o seja)" (José Eduardo Campos de Oliveira Faria. Sociologia..., p. 111-112).

${ }^{233}$ Jacques Chevallier. La juridicisation..., p. 128.

${ }^{234}$ Jacques Chevallier. La rationalisation de la production juridique. In Charles-Albert Morand (org.). L'Etat propulsif. Paris: Publisud, 1991, p. 16. 
De acordo com José Eduardo Faria, essa desenfreada produção legislativa culmina "na ruptura da organicidade, da unidade lógico-formal e da racionalidade sistêmica do ordenamento jurídico e, por consequência, na perda da própria capacidade de predeterminação das decisões concretas por meio do direito positivo" 235.

Uma das consequências desse fenômeno é o modo como altera, em última instância, o fundamento da legitimidade do direito, que, deixa de ser presumido, devendo ser demonstrado através da aplicação rigorosa de métodos de elaboração e da verificação da pertinência de seus efeitos ${ }^{236}$.

Nesse sentido, com o intuito de conter a proliferação anárquica de normas jurídicas, propõe-se submeter o processo de elaboração normativa a mecanismos de avaliação, que funcionem como um filtro de contenção de leis editadas de forma casuística, independentemente de sua real necessidade.

Outra forma de lidar com a expansão do direito, que se manifesta tanto na proliferação de normas jurídicas, quanto no grau de complexidade adquirido por essas normas, é adaptá-lo aos problemas concretos e aproximá-lo dos indivíduos, adequando-o ao contexto social que pretende regular ${ }^{237}$.

Nesse âmbito, tratando-se de um direito mais flexível e pragmático, para minimizar o conflito entre os diversos interesses sociais que se expressam nas leis, os destinatários das normas jurídicas são convidados a participar do seu processo de elaboração.

Isso significa rever a forma de conceber o processo de formulação de normas, afastando-se a idéia de um legislador racional e aproximando-se da possibilidade de intervenção de diferentes atores, que não se relacionam entre si ou com o Estado de maneira hierárquica, mas em condições de igualdade.

Essa participação ocorre não só por meio da contribuição de especialistas sobre o tema que a norma a ser elaborada pretende regulamentar, como pela presença dos interesses de categorias sociais ou profissionais.

${ }^{235}$ José Eduardo Campos de Oliveira Faria. O direito na economia globalizada. $1^{\mathrm{a}}$ ed. $3^{\mathrm{a}}$ tiragem. São Paulo: Malheiros, 2002, p. 117.

${ }^{236}$ Jacques Chevallier. L'État post-moderne. Droit et Société, n. 35. Paris: L.G.D.J., 2008, p. 146.

${ }^{237}$ Jacques Chevallier. La régulation juridique en question. Droit et Société, 49, 2001, p. 833. 
Conforme mencionado, as transformações que afetam o direito não se relacionam apenas ao aumento da participação de diversos atores no processo de elaboração das normas, mas na possibilidade de, diante da diversidade e complexidade dos temas que demandam regulamentação, trazer uma maior quantidade de informação técnica para contribuir com a formulação da lei e a tomada de decisão política.

Isso porque o processo de produção de normas deve se orientar pelo conhecimento da realidade social que o direito busca regular, e das reações que sua aplicação pode desencadear ${ }^{238}$.

Para se obter o maior número de informações sobre a realidade em que o direito irá incidir, é preciso recorrer aos especialistas sobre o campo de intervenção que se deseja regulamentar, coletar dados cada vez mais refinados, desenvolver tecnologias de informação avançadas e aplicar técnicas cada vez mais sofisticadas de avaliação prospectiva e retrospectiva de cada ação ${ }^{239}$.

Conforme vem sendo analisado, as inovações introduzidas pela noção de gestão de políticas públicas ${ }^{240}$ influenciaram o direito em dois aspectos. Em primeiro lugar, ao considerá-lo como um dos instrumentos à disposição do Estado para responder às demandas sociais e implementar suas políticas ${ }^{241}$.

Nesse âmbito, interessa conhecer quais são os instrumentos jurídicos que podem ser utilizados na tarefa de implementação de políticas públicas porque quanto maior a apreensão dos mecanismos a disposição, maior é a chance de efetividade da política que se quer executar ${ }^{242}$.

\footnotetext{
${ }^{238}$ Charles-Albert Morand. Le droit néo-moderne..., p. 105.

${ }^{239}$ Charles-Albert Morand. Le droit néo-moderne..., p. 105.

${ }^{240}$ Patrice Duran. Piloter l'action publique..., p. 6. De acordo com o autor, trata-se do conjunto de atividades práticas ligadas entre si em razão da necessidade de realização de um objetivo comum. Maria Paula Dallari Bucci define políticas públicas como "programas de ação governamental visando a coordenar os meios à disposição do Estado e as atividades privadas, para a realização de objetivos socialmente relevantes e politicamente determinados" (Direito administrativo e políticas públicas. São Paulo: Saraiva, 2006, p. 241). ${ }^{241}$ Patrice Duran. Piloter l'action publique..., p. 6.

${ }^{242}$ Maria Paula Dallari Bucci. Direito administrativo..., p. 249. Não é o caso de discutir, como o faz a autora, como as políticas públicas podem ser assimiladas como direito, a partir da noção de que "a realização das políticas deve ocorrer dentro dos parâmetros da legalidade e da constitucionalidade, o que implica que passem a ser reconhecidos pelo direito - e gerar efeitos jurídicos - os atos e as omissões que constituem cada política pública". Nesse sentido, a política distingue-se das normas e atos jurídicos, embora esses elementos sejam parte integrante dela (Direito administrativo..., p. 255).
} 
Em segundo lugar, pela inserção dos principais marcos teóricos de análise de políticas públicas na forma de conceber o direito, especialmente sua formulação, cuja tarefa passa a ser vista como uma política pública legislativa, a ser submetida, portanto, aos mesmos mecanismos de desenho, implementação e avaliação das demais políticas públicas.

Nesse sentido, considerar que a elaboração de textos normativos é uma tarefa que se insere na lógica de gestão pública é admitir a necessidade de (i) realização de um trabalho de coleta e tratamento de dados e de estudos prévios destinados a balizar a tomada de decisões; (ii) recurso a mecanismos de auxílio à decisão e de dispositivos de simulação; (iii) utilização de processos de experimentação ou de avaliação ex ante dos efeitos passíveis de serem previstos ${ }^{243}$.

Diante das mudanças apresentadas, diversos autores propõem uma reformulação da concepção do direito, com o intuito de municiá-lo de instrumentos que contribuam com a tarefa de responder de forma efetiva às demandas sociais e políticas e que sejam capazes de conter sua proliferação anárquica e desenfreada.

Conforme já mencionado, é importante lembrar que não se trata de uma ruptura radical com o modelo de direito anterior. Ao contrapor os modelos de direito que denomina de moderno e pós-moderno, Jacques Chevallier, por exemplo, afirma que as relações entre eles não se colocam em termos de substituição, mas, pelo contrário, de coexistência, ou mais exatamente, de imbricação ${ }^{244}$.

Segundo esse autor, os elementos que caracterizam o direito pós-moderno já estavam presentes antes, no direito moderno: a tese do pluralismo jurídico não é nova, as técnicas de consulta dos interesses sociais sempre existiram, ainda que sob formatos

\footnotetext{
${ }^{243}$ Jacques Chevallier. La juridicisation des precepts manageriaux..., p. 115.

244 Segundo ele, "a pós-modernidade é igualmente engolida pela modernidade que ela desnatura". Ao concluir que não há, portanto, incompatibilidade radical entre os dois tipos de direito, Jacques Chevallier afirma que "a pós-modernidade jurídica pode ser concebida sob outro viés: como processo de adaptação do direito moderno ao novo contexto das sociedades contemporâneas, ou melhor, como ativação de dimensões já presentes no coração da modernidade. Não somente a racionalização dos processos jurídicos, característica da pós-modernidade, traduz a persistência do império da razão, mas ainda a juridicização mostra que o direito reste mais do que nunca o dispositivo privilegiado de enquadramento das relações sociais" (Tradução livre de Vers un droit post-moderne?..., p. 682).
} 
diferentes, a mudança das normas ocorria pela busca de maior eficácia, não havendo, portanto, em sua opinião, incompatibilidade radical entre os dois tipos de direito ${ }^{245}$.

Ao analisar as características desse modelo de direito, Charles-Albert Morand afirma que há diferença na forma como as normas se estruturam, pois as relações entre elas parecem mais hierarquias emaranhadas do que uma pirâmide, como afirmava Kelsen ${ }^{246}$.

Para ele, que considera uma hierarquia emaranhada a interação entre níveis nos quais as influências são recíprocas, não é possível dizer que apenas a norma superior influencia a norma inferior se existem diversos casos em que a norma inferior, por exemplo, uma decisão judicial, altera a forma de interpretar a norma superior, como a Constituição $^{247}$.

Nesse sentido, é possível afirmar que há, mesmo nas ordens jurídicas internas fortemente hierarquizadas, diversas relações horizontais de coordenação que se operam por ajustamentos mútuos, por convergência de princípios diretores, por aplicação de outros princípios e por imbricação ${ }^{248}$.

Ao sistema de direito classicamente pensado como um modelo de pirâmide e organizado segundo relações ramificadas, aparece, portanto, como substituto, a representação em redes, com relações recursivas e processos circulares ${ }^{249}$.

No âmbito de sua formulação, começa a surgir a necessidade de se identificar quem é o legislador, questionando-se a sua associação a um ente abstrato capaz de representar a vontade geral, ainda que essa concepção siga sendo utilizada como justificativa teórica para a análise do direito apenas a partir de sua promulgação.

Nesse contexto, a lei como expressão da vontade geral perde muito da sua credibilidade, inclusive em razão de uma percepção mais crítica da democracia representativa, na qual o princípio da maioria passa a ser visto como um instrumento que

\footnotetext{
${ }^{245}$ Vers un droit post-moderne?..., p. 682.

${ }^{246}$ Charles-Albert Morand. Le droit néo-moderne..., p. 34.

${ }^{247}$ Charles-Albert Morand. Le droit néo-moderne..., p. 34.

${ }^{248}$ Charles-Albert Morand. Le droit néo-moderne..., p. 35.

${ }^{249}$ Pierre Lascoumes. Normes juridiques..., p. 68.
} 
permite fazer prevalecer a vontade de alguns em detrimento de muitos. Nesse sentido, o direito passa a ser visto como o produto da relação de forças sociais e contingentes ${ }^{250}$.

De fato, uma das formas de melhorar a qualidade das leis, diante de sua proliferação, é possibilitar que técnicos, e não só políticos, possam interferir no seu processo de elaboração. Nesse sentido, a lei deixa de ser somente a expressão da vontade geral, para ser uma expressão política de conjunção de esforços coletivos ${ }^{251}$.

Essas modificações implicam a renúncia à ideia de que o direito estatal não será nada mais do que um conjunto de comandos sancionadores, conduzindo a uma visão do direito como um sistema formalizado de organização e gestão de interesses protegidos, com o qual os atores sociais (privados e públicos, individuais e coletivos) se relacionam de forma ativa ${ }^{252}$.

Ao discorrer sobre o sentido do adjetivo "pública" atribuído ao substantivo "política”, Maria Paula Dallari Bucci afirma que "uma política é pública quando contempla os interesses públicos, isto é, da coletividade - não como fórmula justificadora do cuidado diferenciado com interesses particulares ou do descuido indiferenciado de interesses que merecem proteção - mas como realização desejada pela sociedade. Mas uma política pública também deve ser expressão de um processo público, no sentido de abertura à participação de todos os interessados, diretos e indiretos, para a manifestação clara e transparente das posições em jogo" 253 .

Conforme será visto no próximo capítulo, a estrutura do direito começa a ser reformulada, mediante a introdução de mecanismos de participação e de avaliação. Entretanto, antes de analisar os instrumentos que buscam aproximar o direito dos seus destinatários e, ainda, conter sua expansão, como forma de assegurar a eficácia de suas medidas, é preciso compreender a fundamentação teórica que sustenta essas transformações.

\footnotetext{
${ }^{250}$ Jacques Chevallier. L'État post-moderne..., p. 106.

${ }^{251}$ François Terré. La « crise de la loi ». Archives de philosophie du droit, tome 25, 1980, p. 21.

${ }^{252}$ Pierre Lascoumes. Normes juridiques..., p. 45.

${ }^{253}$ Maria Paula Dallari Bucci. Direito administrativo..., p. 269.
} 


\section{A legitimidade democrática}

A partir do século $\mathrm{XX}$, os teóricos do direito começam a se preocupar com a legitimidade, conferida ao Estado pelo direito, que se fundamenta na existência de regras formais, capazes de assegurar o funcionamento da máquina estatal independentemente do viés ideológico que se esconde por trás das leis ${ }^{254}$.

Essa preocupação é resultado da reflexão sobre as consequências dos regimes políticos totalitários, dos quais não foi possível subtrair os atributos de uma democracia, na medida em que se verificava a identidade da lei com a vontade popular, ainda que o povo tenha sido concebido de maneira simbólica.

Conforme afirma Menelick de Carvalho, a concepção puramente simbólica do povo ${ }^{255}$, reduzido à condição de massa, manipulável e instrumentalizada por parte daqueles que se apresentam como seus tutores, considerados superiores em relação aos cidadãos, reduz a sua capacidade de autonomia, desqualificando-os como interlocutores 256

Nessa condição, não é possível, portanto, falar de livre escolha e em respeito de opiniões. De acordo com Chantal Mouffe, "nas sociedades nas quais reina o pluralismo e onde a existência de conflito e divisão já tenha se tornado legítima, não é mais possível conceber o povo como uma entidade unificada e homogênea dotada de uma única vontade

\footnotetext{
${ }^{254}$ Trata-se, conforme analisado acima, da legitimidade considerada como verso da legalidade, preconizada pelo positivismo jurídico desenvolvido no séc. XX, especialmente por Hans Kelsen, que, conforme afirma José Eduardo Faria, se caracteriza pelo apego excessivo ao formalismo e por encarar o direito de modo acrítico, sem construir sobre ele juízos de valor (Verbete legitimidade..., [s.p.]).

${ }^{255}$ Essa noção de povo está relacionada a sua associação à concepção de nação como "entidade abstrata que exprime os interesses permanentes de uma comunidade, que se distinguem nas aspirações dos que a compõem em certo instante histórico", oriunda da democracia representativa. "Entidade abstrata, a Nação tem necessidade de representantes que manifestem sua vontade, exercendo o supremo poder. Ao povo, entendido como aqueles a quem a vontade da Nação conferiu direitos políticos, compete simplesmente eleger os seus representantes. (...) Os representantes eleitos eram representantes da Nação, não do povo. Não tinham, pois, o dever de escutar outra voz que não a da consciência, isto é, a da Nação. Sua tarefa não era exprimir a opinião de seus eleitores, era atender à Nação e, assim, dizer sempre o que era melhor para o todo, ainda que fosse contrário à vontade dos que os haviam elegido. Destarte, os representantes nem recebiam instruções dos eleitores, nem tinham contas a lhes prestar por seus atos" (Manoel Gonçalves Ferreira Filho. A democracia possível. $5^{\text {a }}$ ed. São Paulo: Saraiva, 1979, p. 11).

${ }^{256}$ Menelick de Carvalho Netto. Apresentação. In Michel Rosenfeld. A identidade do sujeito constitucional. Belo Horizonte: Mandamentos, 2003, p. 14.
} 
geral. É necessário repensar a política democrática afim de que ela redefina o pluralismo e a liberdade individual" 257.

Nesse sentido, Pierre Rosanvallon propõe uma mudança de foco da democracia com o abandono da noção de representação pelas eleições e de identificação da vontade geral como fundamento da legitimidade democrática ${ }^{258}$.

De um lado, porque as eleições assumem uma função cada vez mais reduzida, pois servem apenas para validar um modo de designação dos governantes, não implicando mais em uma legitimação a priori dos políticos que ao assumirem os cargos podiam governar livremente ${ }^{259}$.

De outro lado, porque a noção de maioria também adquire outro sentido. "O interesse do maior número não pode ser mais assimilado como ao de uma maioria. $\mathrm{O}$ 'povo' não pode mais ser concebido como uma massa homogênea, ele deve ser visto muito mais como uma sucessão de histórias singulares, uma soma de situações específicas. É por isso que as sociedades contemporâneas são compreendidas cada vez mais a partir da noção de minoria. A minoria não é mais a 'menor parte' (que deve se inclinar diante da 'maior parte'). Ela se torna uma das múltiplas expressões refratadas da totalidade social. A sociedade se manifesta mais na forma de uma grande variação de condições minoritárias. Atualmente o 'povo' é também o plural de 'minoria", 260.

Ao desenvolver novas formas de legitimidade, que resultam de uma desconstrução e redistribuição da idéia de generalidade social ${ }^{261}$, Pierre Rosanvallon

\footnotetext{
${ }^{257}$ Tradução livre de Chantal Mouffe. Penser la démocratie moderne avec, et contre, Carl Schmitt. Revue Française de Science Politique, v. 42, n. 1, 1992, p. 88.

${ }^{258}$ Pierre Rosanvallon. La légitimité démocratique. Impartialité, réflexivité, proximité. Paris: Seuil, 2008, p. 13. Segundo o autor, "ao lado da legitimidade de estabelecimento - relativa à consagração pelas urnas -, uma segunda apreensão da legitimidade democrática emergiu: a de uma identificação à generalidade social. $\mathrm{Na}$ verdade, ela exerceu um papel decisivo como elemento compensador do enfraquecimento da legitimidade eleitoral. Desta maneira, foram conectados duas formas de conceber a legitimidade: a legitimidade derivada do reconhecimento social de um poder, e a legitimidade como adequação a uma norma ou a valores. Essas duas formas cruzadas de legitimidade - procedimental e substancial - deu sustentação aos regimes democráticos a partir do começo do séc. XX. Essa fase começou a mudar nos anos 1980" (Tradução livre de Pierre Rosanvallon. La légitimité démocratique..., p. 13-14).

${ }^{259}$ Pierre Rosanvallon. La légitimité démocratique..., p. 14.

${ }^{260}$ Tradução livre de Pierre Rosanvallon. La légitimité démocratique..., p. 14.

${ }^{261}$ A primeira delas decorre da realização da generalidade pelo distanciamento das particularidades, isto é, pela distância racional e organizada das diferentes partes implicadas em uma questão. Trata-se de uma generalidade negativa, da qual ninguém pode se apropriar, que está associada à legitimidade de imparcialidade. A segunda é a realização da generalidade por meio de um trabalho de pluralização de expressões da soberania social. Trata-se de uma generalidade de freio, pois visa corrigir as imperfeições
} 
afirma que, nesse contexto, a legitimidade nunca é adquirida a priori, pois é sempre precária e desafiada, na medida em que depende da percepção social da ação e do comportamento das instituições ${ }^{262}$.

Se os indivíduos não estão mais representados por um poder soberano que se revela como transcendental e os considerada como uma unidade simbólica, e a democracia implica na aceitação da divergência e do conflito, é preciso pensar em maneiras dos indivíduos se manifestarem, mediante a existência de um processo político de diálogo que incorpore os seus interesses, e respeite, assim, sua complexidade e pluralidade ${ }^{263}$.

De acordo com José Eduardo Faria, "o motivo pelo qual uma comunidade considera legítima uma dada ordem jurídica implica valores que só tem sentido em função do contexto histórico; valores formados pela comunidade mediante a sua capacidade de agir em conjunto, de dialogar, de promover o entendimento mútuo com base nos direitos à comunicação e à participação, que garantem aos cidadãos uma efetiva autonomia pública"264.

Autores como Jünger Habermas e Klaus Günther desenvolvem suas teorias a partir de um teste de universalização, apoiado na teoria do discurso, ao considerar que são válidas as normas às quais todos os possíveis atingidos poderiam ter manifestado seu assentimento ${ }^{265}$. Dessa forma, o representante político não pode deixar seus próprios

resultantes da assimilação de uma maioria eleitoral com a vontade social apreendida em sua globalidade, que está associada à legitimidade de reflexividade. A terceira é a realização da generalidade pela consideração da multiplicidade das situações, isto é, pelo reconhecimento de todas as singularidades sociais. Trata-se de uma generalidade de atenção à particularidade, associada à legitimidade de proximidade. Esses três modos de conceber a generalidade têm em comum o fato de se assentarem numa concepção da totalidade social que não é nem uma agregação aritmética (unanimidade), nem uma perspectiva monista (referência a um interesse social conhecido como uma propriedade estável de um corpo coletivo ou de uma estrutura). Trata-se de uma visão mais dinâmica da generalidade, de uma perspectiva reguladora, não substancial, como as noções de vontade e de interesse geral (Pierre Rosanvallon. La légitimité démocratique..., p. 17-18).

${ }^{262}$ Pierre Rosanvallon. La légitimité démocratique..., p. 19.

${ }^{263}$ Em sua análise, Chantal Mouffe recorda que a vontade geral não pode ser pensada apenas como o resultado da observância de certo número de procedimentos, pois a democracia requer a afirmação de certos valores que constituam seus princípios políticos. Para ela, ainda que pareça impossível defender o máximo de pluralismo sem prescindir do que é constitutivo da democracia que denomina de moderna, em razão do caráter multi-étnico e multi-cultural da sociedade, é justamente da tensão entre a lógica da identidade e a lógica da diferença que advém a necessidade de sua articulação, revelando-se um aspecto de promessa inerente ao ideal democrático (Penser la démocratie moderne..., p. 94-95).

${ }^{264}$ José Eduardo Campos de Oliveira Faria. Verbete legitimidade..., [s.p.].

${ }^{265}$ Flávio Quinaud Pedron. A distinção entre jurisdição e legislação no pensamento de Klaus Günther. Revista CEJ, ano XII, n. 41, abr.-jun. 2008, p. 60. Para Jürgen Habermas, diante de um conflito de valor que não poderia ser resolvido nem por via discursiva, nem por meio de acordo, não se poderia regrar uma situação eticamente controversa em uma sociedade pluralista constituída sob a forma de um Estado democrático de direito com base em uma autocompreensão particular ( $A$ inclusão do outro. Estudos de teoria 
interesses dominarem, devendo sempre se colocar no lugar daqueles que podem ser atingidos pela norma ${ }^{266}$.

Assim, ainda que reconheça o problema de se determinar quais são os interesses que envolvem a justificação de uma norma, uma vez que são mutáveis e circunscritos a certos horizontes históricos e sociais, Klaus Günther, considera como uma exigência ideal que todos os interesses sejam satisfeitos na medida do possível ${ }^{267}$.

Para Jürgen Habermas, "é preciso mudar de perspectiva, os envolvidos precisam deixar de lado a pergunta sobre que regulamentação é melhor para nós e adotar que regulamentação é igualmente boa para todos" 268 .

Segundo Klaus Günther, “o procedimento legislativo democrático se caracteriza por tornar o caráter vinculante do direito dependente de discursos e procedimentos decisórios públicos, nos quais todos os cidadãos têm o direito de tomar parte. Cidadãos em uma democracia não são apenas destinatários, mas também autores de suas normas jurídicas" ${ }^{269}$.

politica. Trad. George Sperber, Paulo Astor Soethe, Milton Camargo Mota. São Paulo: Loyola, 2007, p. 321).

${ }^{266}$ Para os autores, a aplicação de uma norma ao caso concreto também deve seguir os critérios da ética do discurso, garantindo a prevalência do melhor argumento, mas Klaus Günther, por exemplo, considera que a aplicação de normas exige uma perspectiva distinta, pois somente diante da singularidade do caso é que se pode determinar todos os possíveis efeitos de uma norma. Assim, no discurso de justificação da norma, a imparcialidade existe quando se consideram todos os interesses envolvidos, já no discurso de aplicação importam todos os fatos que envolvem o caso concreto (Argemiro Martins e Cláudio de Oliveira. A contribuição de Klaus Günther ao debate. Revista Direito GV, v. 2, n.1, jan.-jun. 2006, p. 245). Ver, no texto original, Klaus Günther. The sense of appropriateness: application discourses in morality and law. Trad. John Farrell. New York: State University of New York, 1993, p. 87-88. Para esse autor, todas as normas produzidas por meio do discurso de justificação são válidas, sendo aplicáveis prima facie, entretanto, apenas diante de uma descrição completa do caso, considerando-se suas circunstâncias específicas, isto é, da reconstrução completa da situação de fato, é que se torna possível definir qual será a norma aplicada.

${ }^{267}$ Argemiro Martins e Cláudio de Oliveira. A contribuição de Klaus Günther..., p. 244. Para Klaus Günther, "uma norma é válida se as consequências e os efeitos colaterais de sua observância puderem ser aceitos por todos, sob as mesmas circunstâncias, conforme os interesses de cada um, individualmente".

${ }^{268}$ Jürgen Habermas. A inclusão do outro..., p. 322. Segundo o autor, o preço a pagar pela convivência nos limites de uma comunidade jurídica igualitária, na qual diversos grupos de origem cultural e étnica distintas precisam relacionar-se uns com os outros, é a tolerância, capaz de assegurar que permaneça intacto o fundamento do respeito recíproco das pessoas do direito uma pelas outras (A inclusão do outro..., p. 323).

${ }^{269}$ Klaus Günther. Qual o conceito de pessoa de que necessita a teoria do discurso do direito? Reflexões sobre a conexão interna entre pessoa deliberativa, cidadão e pessoa de direito. Trad. Flavia Portella Püschel. In Teoria da responsabilidade no Estado democrático de direito: textos de Klaus Günther. Flavia Portella Püschel e Marta Rodriguez de Assis Machado (org.). São Paulo: Saraiva, 2009, p. 31. Segundo o autor, dessa concepção decorrem alguns pressupostos, como a capacidade de uma pessoa de se distanciar de ações e proferimentos e se posicionar de maneira crítica. "Denomino uma posição de 'crítica' quando se apóia em razões (Gründe). Uma pessoa à qual se atribui a capacidade de posicionar-se criticamente pode, portanto, realizar o ato cognitivo de posicionamento fundamentado em relação a proferimentos e ações. Além disso, ela está em condições de seguir as razões que aceitou, isto é, de realizar um ato volitivo. (...) 'Razões' são 
Dessa forma, a teoria do discurso assume duas posições: (i) são os próprios cidadãos que decidem sobre o direito posto e (ii) o procedimento jurídico de decisão é racional, ou seja, permite o exame de propostas de normas por meio de crítica $\operatorname{argumentativa}^{270}$.

"A validade positiva do direito funda-se apenas na produção da norma em conformidade com o procedimento, e não na posição concordante ou discordante do cidadão individual. Por isso, ele vincula também aqueles cidadãos que não fizeram uso de seu direito de participação ou que, como participantes do procedimento democrático, não foram convencidos a reconsiderar sua discordância. O dever de cada cidadão de obedecer à norma funda-se apenas no seu direito igual ao exercício público de sua capacidade de crítica e no procedimento juridicamente institucionalizado no âmbito do qual tal direito pode ser exercido de modo eficaz, mas não no se e como e também não no resultado de cada exercício fático desse direito. Concluindo, são a capacidade de posicionamento crítico, atribuída à pessoa deliberativa, e o direito subjetivo igual ao exercício eficaz dessa capacidade em procedimentos democráticos institucionalizados juridicamente que, em conjunto, fundamentam a pretensão de vinculação do direito positivo" ${ }^{271}$.

Nesse sentido, Jacques Chevallier afirma que a participação no processo legislativo tem, na verdade, o efeito de conferir as leis os atributos de democracia, ao demonstrar que o legislador busca obter um consenso mínimo e leva em consideração as preferências e resistências de diversos grupos sociais ${ }^{272}$.

Segundo o autor, essa abertura aos representantes de grupos sociais permite localizar os conflitos, balizar os terrenos de enfrentamento, situar as zonas de compromisso

(entre outras coisas) definidas pelo fato de fazerem diferença no mundo, pelo fato de que podem motivar uma pessoa a mudar seus proferimentos e ações no sentido de uma correção". Uma pessoa capaz de se manifestar criticamente é uma pessoa deliberativa. Além de poder fundamentar sua posição crítica com razões, uma pessoa deliberativa deve poder tomar parte em argumentações nas quais pretensões de validades relativas a proferimentos são levantadas, criticadas por meio de razões e defendidas com contrarazões (Qual o conceito de pessoa..., p. 32-33).

${ }^{270}$ Klaus Günther. Qual o conceito de pessoa..., p. 27-28. Para Habermas, “a idéia por detrás do Estado de Direito moderno requer que as decisões coletivamente vinculantes do poder estatal organizado (Staatsgewalt), que deve empregar o Direito para cumprir as suas próprias funções, não são apenas revestidas pela forma do Direito, mas são, por sua vez, legitimadas por uma lei legitimamente promulgada. Não é a forma jurídica enquanto tal que legitima o exercício da dominação política, mas tão só o vínculo com a lei legitimamente promulgada. E, em um nível pós-convencional de justificação, só são consideradas legítimas as leis passíveis de serem racionalmente aceitas por todos os co-associados em um processo discursivo de formação de opinião e vontade" (Jürgen Habermas. Faticidade e validade: uma introdução à teoria discursiva do direito e do Estado democrático de Direito. Trad. Menelick de Carvalho, no prelo, p. 97).

${ }^{271}$ Klaus Günther. Qual o conceito de pessoa..., p. 38-39.

272 Jacques Chevallier. La juridicisation des precepts manageriaux..., p. 125. 
possíveis, ou seja, busca à melhor adaptação das regras e à eliminação de eventuais reações de rejeição ${ }^{273}$.

Nesse contexto, a segurança jurídica, que para o positivismo jurídico é tão importante, não advém da previsibilidade do resultado da norma, independentemente das circunstâncias do caso concreto, mas da garantia de participação de todos no processo decisório. "A 'segurança', portanto, migra da previsibilidade de resultado para a garantia de direitos participatórios nos processos de tomada de decisão estatal" 274 .

Dessa forma, é a participação na definição da regra que assegura seu mérito; o direito se torna um direito negociado, resultado de deliberação coletiva. À legitimidade intrínseca, fundada na representação do direito como encarnação da razão, sucede uma legitimidade procedimental, atestada pelo seu modo de elaboração ${ }^{275}$.

O processo legislativo se configura, portanto, como um espaço de deliberação, aberto a todos interessados, onde o direito a ser formulado pode ser discutido. Nesse âmbito, ainda que a participação não seja efetiva, deve ser em potencial e o legislador precisa se posicionar considerando sempre os interesses dos destinatários das normas.

É importante ressaltar que não se trata de abandonar a perspectiva de que a legitimidade do poder tem relação com a sua legalidade, ou seja, de que a norma posta pode ser vista como a solução mais adequada aos conflitos, sendo por isso, aceita pelos indivíduos, mas de assumir que não se trata de qualquer legalidade, mas de uma legalidade produzida de um modo diferente, não fundamentada apenas nos aspectos formais do direito, mas em um espaço aberto à participação de todos os cidadãos.

Conforme visto, essa participação é menos a garantia de que todos efetivamente se manifestem no processo legislativo do que a possibilidade de debater sobre os interesses envolvidos de forma argumentativa. Não se trata apenas da passagem da concepção do povo como unidade simbólica para uma consideração de fato dos interesses das minorias, mas da observância de todos os interesses envolvidos mediante um procedimento baseado na apresentação de argumentos que podem ser contestados com a colocação de contra-argumentos.

\footnotetext{
273 Jacques Chevallier. L'État post-moderne..., p. 141.

${ }^{274}$ Flávio Quinaud Pedron. A distinção entre jurisdição e legislação..., p. 62.

275 Jacques Chevallier. Vers un droit post-moderne?..., p. 675.
} 
Reconhecendo-se as limitações que advém dessas correntes de pensamento que privilegiam a formação discursiva da vontade, é importante dizer, por fim, que não se trata de conferir legitimidade apenas ao ordenamento jurídico capaz de encontrar o assentimento de todos, diante das dificuldades que cercam alguns temas como o do consenso ${ }^{276}$, mas de, admitindo-se que a questão da legitimidade é complexa e aberta, resgatar, nessas correntes, a possibilidade de identificar o processo legislativo como um espaço aberto ao debate, substituindo-se a ideia de um legislador racional, que impõe normas, pela de um legislador que é mais um ator desse processo, devendo, considerar, portanto, todos os interesses envolvidos.

Mais do que isso, o processo legislativo precisa ser visto como um lugar de discussão de argumentos, mais do que de imposição de opiniões pessoais, alargando-se, dessa forma, o conceito de democracia.

\section{O Poder Legislativo como um espaço de deliberação democrática}

As teorias democráticas contemporâneas contribuem em certa medida para a reflexão do Poder Legislativo como um espaço de deliberação que não se impõe apenas pela observação do princípio da maioria, mas pela possibilidade de colocação de interesses diversos, que podem ser debatidos de forma argumentativa.

De fato, é mais comum que o Poder Judiciário seja visto como o lugar de resolução de questões socialmente relevantes e, mais do que isso, como o único capaz de proteger os direitos constitucionais, que estariam totalmente ameaçados se pudessem ser debatidos em instituições majoritárias como o Poder Legislativo ${ }^{277}$.

O controle de constitucionalidade dos atos normativos ilustra bem a representação das Cortes Constitucionais como o único espaço aberto à reflexão e argumentação jurídicas.

\footnotetext{
${ }^{276}$ Isso porque "em alguns momentos, a produção de decisões consensuais - que superem os pontos de vista discordantes -, é incompatível com o grau de exigência técnica das decisões de política pública que os governos têm de tomar. Por sua urgência e complexidade, há matérias - como juros e moeda - que não podem depender do debate público. E, pela multiplicidade de interesses em jogo, decisões unânimes acerca dessas matérias são impossíveis de serem obtidas" (José Eduardo Campos de Oliveira Faria. Verbete legitimidade..., [s.p.]).

${ }^{277}$ Ver, nesse sentido, Ronald Dworkin. Law's empire. Cambridge: Harvard University Press, 1986.
} 
No Brasil, o controle preventivo dos atos emanados pelo Poder Executivo pode ser feito pelas comissões de constituição e justiça das duas casas que compõem o Poder Legislativo, bem como o Presidente da República pode sancionar ou vetar os projetos de leis de autoria do Poder Legislativo, impedindo-se, assim, a inserção no ordenamento jurídico de uma lei contrária à Constituição Federal. Já o Poder Judiciário é responsável pelo controle repressivo de constitucionalidade, realizado quando a lei já está em vigor.

Em geral, esse controle é visto como uma atividade estanque, como se cada poder pudesse exercer a sua análise de constitucionalidade sem considerar a participação de todos no cenário político.

Além disso, o que se verifica é a predominância, nesse controle, de atuação do Poder Judiciário, configurando-se um fenômeno que tem sido denominado de “judicialização da política" 278.

A judicialização da política consiste no recurso, cada vez mais freqüente, ao Poder Judiciário como forma de ampliar a proteção constitucional aos direitos sociais e coletivos, nos casos em que se nega a efetivação de tais direitos. Ocorre, portanto, uma abertura cada vez maior à inserção do Poder Judiciário na arena política, como forma de garantir a realização dos direitos fundamentais ${ }^{279}$.

\footnotetext{
${ }^{278}$ Segundo Loiane Prado Verbicaro, “a judicialização da política surge em um contexto de maior inserção quantitativa e qualitativa do Poder Judiciário na arena política" (Um estudo sobre as condições facilitadoras da judicialização da política no Brasil. Revista Direito GV, 4 (2), jul.-dez. 2008, p. 391). Ver, sobre o tema, José Eduardo Campos de Oliveira Faria. O direito na economia globalizada..., p. 134-135.

279 Loiane Prado Verbicaro. Um estudo sobre as condições..., p. 394. A autora aponta treze condições facilitadoras e/ou propiciadoras desse processo de intervenção do Poder Judiciário em assuntos políticos, relacionadas com o contexto brasileiro, especialmente a partir do processo de redemocratização e reconstitucionalização, bem como a fatores globais verificados nas democracias contemporâneas. São elas: 1) a promulgação da Constituição Federal de 1988, que trouxe mudanças valorativas ao direito, atribuindo crescente importância aos princípios constitucionais; 2) a universalização do acesso à justiça; 3) a estrutura tripartite de organização dos poderes do Estado, com o reconhecimento da independência e autonomia de funcionamento a cada um deles e a autorização conferida ao Poder Judiciário para atuar como poder limitador dos atos e decisões dos outros poderes; 4) a existência de normas constitucionais programáticas e cláusulas indeterminadas, em detrimento das categorias e definições precisas e unívocas cultivadas pela dogmática jurídica; 5) a crise do paradigma positivista e do modelo formalista de interpretação; 6) a ampliação da participação do Supremo Tribunal Federal na resolução de conflitos constitucionais mediante o controle de constitucionalidade de atos normativos; 7) a permissão constitucional de edição de medidas provisórias pelo Poder Executivo, sem que haja o estabelecimento de limites claros e precisos quanto ao seu uso; 8) a ampliação do rol dos legitimados ativos a propor a ação direta de inconstitucionalidade e agir em defesa de direitos coletivos; 9) o processo de industrialização e de desenvolvimento econômico tardio, que refletiram na formação da conflituosidade social e na demanda por justiça na sociedade brasileira; 10) a existência de novas forças sociais representadas por movimentos, organizações e grupos sociais que passaram a se mobilizar e a recorrer ao Poder Judiciário em busca do reconhecimento e da concretização dos seus direitos; 11) o agravamento da crise econômica nas últimas décadas do século XX, a ineficácia da política macroeconômica do País e a conseqüente explosão da crise social, que provocaram intensa procura dos
} 
Nesse contexto, de maior acessibilidade dos espaços judiciais, parece ser mais fácil localizar o debate público no Judiciário do que no Parlamento, como se a ordem jurídica só pudesse se afirmar entre operadores do direito.

Verifica-se, ainda, que esse deslocamento do debate público não ocorre apenas porque se trata de um espaço frequentado por especialistas em direito, mas também porque, diante da possibilidade da sociedade civil de interpor amici curiae em casos de interesses supra-individuais, bem como da realização de audiências públicas em casos de grande relevância ${ }^{280}$, torna-se mais vantajoso e menos custoso, influenciar o processo de tomada de decisões no âmbito do Judiciário do que do Legislativo.

Não se trata apenas de proteger as normas constitucionais dos potenciais ataques da política, consubstanciada nas decisões do Poder Legislativo, diante de sua suposta incapacidade de cumprir os ideais democráticos de justiça e igualdade, mas de exercer um papel de criador de regras, o que significaria assumir uma função relacionada ao exercício de poder, e não só de autoridade, que, de acordo com Oscar Vilhena, “deveria ficar reservada a órgãos representativos, pois quem exerce poder em uma república deve sempre estar submetido a controles de natureza democrática" ${ }^{281}$.

As expectativas no Poder Judiciário não são apenas sociais, mas provocam reflexos, também, na atuação dos outros poderes. De uma parte, o Poder Legislativo, diante da conjuntura política de aprovação de determinado projeto de lei, deixa de lado a análise de constitucionalidade ou de juridicidade, considerada muito técnica e deslocada da necessidade de conceder respostas a problemas concretos, adotando, como a melhor solução, a aprovação da lei sem discussão de questões jurídicas ou constitucionais, que poderão ser decididas pelo Poder Judiciário.

cidadãos ao Poder Judiciário a fim de restabelecer seus direitos fundamentais violados e/ou não implementados pelo Poder Público; 12) a hipertrofia legislativa ou sobrejuridificação da realidade social; 13) a desproporcionalidade da representação política e a crescente ineficácia do sistema político-decisório na implementação de políticas públicas, o que enseja a necessidade de uma atuação substancial do Poder Judiciário a fim de tutelar os direitos fundamentais constitucionais dos cidadãos.

${ }^{280}$ Oscar Vieira Vilhena. Supremocracia. Revista Direito GV 8, v. 4, n. 2, jul.-dez. 2008, p. 448.

${ }^{281}$ Oscar Vieira Vilhena. Supremocracia..., p. 446. Segundo o autor, essa realidade decorre, dentre outros motivos, da ambição da Constituição de 1988, que "transcendeu os temas propriamente constitucionais e regulamentou pormenorizada e obsessivamente um amplo campo das relações sociais, econômicas e públicas", que faz com que tudo seja matéria constitucional, dando ao corpo político um campo de liberdade muito pequeno, já que qualquer movimento mais brusco dos administradores ou legisladores gera um incidente de inconstitucionalidade (Oscar Vieira Vilhena. Supremocracia..., p. 446-447). 
Nesse âmbito, diante da incapacidade de formular leis claras, sem lacunas e coerentes com o ordenamento jurídico, o Legislativo acaba transferindo ao Poder Judiciário a tarefa de atribuir sentido às leis ao aplicá-las em um caso concreto ${ }^{282}$.

Além disso, o controle dos atos normativos acaba se tornando o meio pelo qual determinados grupos, especialmente os partidos minoritários, viabilizam sua participação no processo legislativo, ao vislumbrarem no Poder Judiciário uma alternativa às disputas travadas no Poder Legislativo.

De outra parte, o Poder Executivo, ao implementar políticas públicas, tem que conciliar interesses divergentes e, em geral, lida com problemas urgentes e prazos curtos para resolvê-los. O tempo decisório e a diversidade de interesses também pode fazer com que o Poder Executivo prefira deixar ao Poder Judiciário a tarefa de discutir a constitucionalidade dos atos normativos emanados em razão da execução dessas políticas.

Além disso, a formulação dessas políticas por meio da elaboração de projetos de leis ou medidas provisórias representa, na maioria das vezes, a aplicação de institutos novos, ainda não consolidados no direito. Nesse sentido, a elaboração de atos normativos que inaugurem novas teses jurídicas não deixa de ser uma aposta do Poder Executivo, que considera sempre que o Poder Judiciário poderá se manifestar, posteriormente, sobre a constitucionalidade desses atos.

Nesse contexto, o Poder Judiciário assume o papel de legitimador das decisões do poder político. Segundo José Eduardo Faria, “em princípio, o sistema político pode adiar suas decisões à espera de melhor oportunidade para agir, encarando a própria Constituição como forma relativamente maleável de tomada de decisões coletivas. $\mathrm{O}$ mesmo não acontece com os tribunais. Por sua natureza, estrutura e função, eles não podem deixar de decidir quando devidamente acionados pela sociedade, mesmo que as normas a serem aplicadas tenham uma textura aberta, sejam indeterminadas, antinômicas ou lacunosas" 283 .

\footnotetext{
${ }^{282}$ Segundo José Eduardo Faria, no Brasil, essa dificuldade começa a aparecer nos anos 80, quando o legislador ordinário, ao modernizar a legislação processual, passou a delegar competência aos juízes, e se torna visível na Assembléia Constituinte, quando seus integrantes optam por redigir uma Constituição com textura aberta e recorrem às normas programáticas nas questões abertas, diante da ausência de bancadas hegemônicas capazes de dar um mínimo de unidade conceitual e coerência programática à nova ordem constitucional (Direito e justiça no século XXI: a crise da justiça no Brasil. Seminário "Direito e Justiça no século XXI", Coimbra, Centro de Estudos Sociais, 2003, p. 15).

${ }^{283}$ Direito e justiça no século XXI..., p. 16.
} 
Ao Judiciário não cabe, entretanto, suprir a incapacidade decisória dos outros poderes ${ }^{284}$. Em primeiro lugar, porque a tutela de direitos não deve ser reduzida a um poder com função contra-majoritária, que, em regra, precisa manter sua neutralidade.

Além disso, se, como afirma José Eduardo Faria, "um dos papeis da democracia é manter elevadas as possibilidades de escolhas e abertas as alternativas de decisões, quando elas são reduzidas drasticamente, os direitos fundamentais e as liberdades públicas acabam sendo comprometidos" 285 .

No limite, portanto, tirar as decisões políticas do âmbito do Poder Legislativo pode ser considerado um atentado à democracia, por representar, conforme afirma Ingeborg Maus, o deslocamento do centro decisório para uma esfera que, por definição, é bem mais restrita e fechada à participação político-partidária do que o Legislativo ${ }^{286}$.

O Poder Judiciário, nesse contexto, deve exercer apenas o controle do processo político de decisão, na medida em que sua observância pode levar, no limite, a um desequilíbrio entre a regra da maioria e os direitos das minorias, que deve ser equalizado por um tribunal neutro e apolítico.

Inclusive, quando autores como Robert Alexy afirmam que a chave para a conciliação entre direitos fundamentais e democracia é a concepção do tribunal constitucional como guardião dos direitos fundamentais, encontrando-se, portanto, acima do processo político, querem dizer que as cortes constitucionais não podem, em razão desse papel, abdicar da função de representante do povo, o que ocorre de forma argumentativa, isto é, mediante a apresentação de argumentos que encontrem uma repercussão no público e nas instituições políticas, que levam a reflexões e discussões, e sejam aceitos pelos cidadãos ${ }^{287}$.

\footnotetext{
${ }^{284}$ José Eduardo Campos de Oliveira Faria. Direito e justiça no século XXI..., p. 18.

${ }^{285}$ Direito e justiça no século XXI..., p. 19.

${ }^{286}$ Sabino Fleury. Judicialização da política e politização da justiça: os partidos políticos e o controle da constitucionalidade das leis no Brasil. Cadernos da Escola do Legislativo, Belo Horizonte, v. 12, n. 18, jan.jun. 2010, p. 43. Ver Ingeborg Maus. Judiciário como superego da sociedade. Novos Estudos CEBRAP, n. 58, nov. 2000.

${ }^{287}$ Robert Alexy. Constitucionalismo discursivo. Tradução Luís Afonso Heck. Porto Alegre: Livraria do Advogado, 2007, p. 53-54.
} 
Isso não quer dizer, entretanto, que o Poder Legislativo deve ser renegado como um espaço de discussão argumentativa, como se apenas o Poder Judiciário tivesse condições de exercer essa função.

Na verdade, a jurisdição constitucional precisa encontrar argumentos melhores do que o legislador para justificar sua atuação, funcionando como instância de reflexão do processo político mediante a comunicação com os outros poderes.

Nesse sentido, Louis Fisher desenvolve sua teoria da "construção coordenada", segundo a qual o Executivo e o Legislativo necessariamente compartilham com o Judiciário um papel importante na interpretação da Constituição ${ }^{288}$.

Assim, a participação dos indivíduos no processo político como sujeitos ativos da soberania não pode levar a uma negociação incessante, diante da diversidade de interesses, nem autorizar a deliberação sobre determinados valores ${ }^{289}$, que funcionam como limites à vontade irrestrita da maioria.

É por isso que, diante dessa tensão, alguns juristas retomam a necessidade de atribuir ao direito a tarefa de proteção de alguns direitos mínimos, que devem permear todas as etapas, da elaboração até a aplicação das normas.

Trata-se de superar a concepção da democracia como representação simbólica do povo, que legitima a atuação do poder político pela realização de eleições periódicas, ampliando-se a esfera de legitimidade da democracia para a plena realização dos direitos fundamentais.

Isso quer dizer que não é apenas o Poder Judiciário que pode ser reconhecido como o guardião dos direitos constitucionais. Esses direitos também podem ser respeitados no processo deliberativo que ocorre no Poder Legislativo, desde que se amplie a oportunidade de participação, o que assegura, em última instância, que os participantes apresentem seus argumentos e que estes sejam debatidos de maneira pública, de forma

\footnotetext{
288 Louis Fisher. Constitucional dialogues: interpretation and political process. New Jersey: Princeton University Press, 1988, p. 232.

289 Verifica-se, em certa medida, a aproximação do direito posto ao jusnaturalismo, numa tentativa de superação do positivismo jurídico clássico, que, de certa forma, justificou as atrocidades cometidas pelos regimes totalitários.
} 
crítica, a partir do levantamento de contra-argumentos, num processo contínuo de discussão.

\section{Proposta de reformulação do direito penal}

No âmbito do direito penal, a necessidade de preservar alguns núcleos estruturais é mais presente do que em outras áreas do direito. Isso porque a resistência ao processo de deliberação tende a ser maior quando se trata da proteção a direitos relacionados à liberdade de ir e vir, que devem ser preservados independentemente da vontade da maioria.

De fato, quando se volta o olhar para a produção legislativa na área penal percebe-se a recorrência, na elaboração de projetos de leis, ao estabelecimento de novos tipos penais e a instituição de penas cada vez maiores, o que afeta diretamente a estrutura jurídico-penal construída com base nos valores e garantias constitucionais e impede, em última instância, a inovação na produção de normas penais ${ }^{290}$.

Ainda que haja uma tendência dos juristas a criticar a produção desenfreada de normas penais, por contrastar com princípios constitucionais como da intervenção mínima e da subsidiariedade, observa-se que é justamente essa postura de repúdio que provoca o distanciamento entre juristas e políticos e, no limite, impede a inovação na forma de pensar e elaborar o direito penal.

Considerando a postura adotada pelos juristas diante do processo legislativo, examinada no capítulo anterior, percebe-se que os mesmo juristas que criticam as leis elaboradas como resposta aos anseios punitivos da sociedade, não se propõem a discutir e apresentar argumentos que qualifiquem o debate parlamentar, pois partem do pressuposto de que sua atuação se limita à observação da norma posta.

\footnotetext{
${ }^{290}$ Sobre essa questão, ver a pesquisa elaborada em 2009 pela Escola de Direito da Fundação Getúlio Vargas cujo título é "Atividade legislativa e obstáculos à inovação em matéria penal no Brasil”, elaborada no âmbito do "Projeto Pensando o Direito III", do Ministério da Justiça em parceria com o PNUD, que buscou desvendar a dinâmica de funcionamento do processo de elaboração normativa por meio da reconstituição dos principais argumentos mobilizados nas proposições legais que propõem mudanças no ordenamento jurídico penal.
} 
Os juristas não percebem que, ao se negarem a participar do processo de elaboração de normas, acabam sedimentando suas teorias independentemente das visões políticas do mundo ${ }^{291}$ e colaboram, de certa forma, para a reprodução do que Álvaro Pires denomina de "racionalidade penal moderna", permanecendo como prisioneiros de determinado modo de pensar o direito ${ }^{292}$.

Se de um lado, os políticos reproduzem essa forma de pensar, que já se encontra consolidada, ao traduzirem os anseios sociais a partir da lógica de proteção da sociedade por meio da punição ${ }^{293}$, de outro, os juristas não aproveitam a oportunidade para "testar" suas teorias, submetendo-as a uma prova argumentativa, o que no limite poderia contribuir, inclusive, para reafirmar os valores constitucionais que se preocupam tanto em proteger $^{294}$.

${ }^{291}$ Álvaro Pires, André Cellard e Gérald Pelletier. L'énigme des demandes de modifications législatives au
Coderiminel
canadien. http://classiques.uqac.ca/contemporains/pires alvaro/enigme demandes modification/enigme demandes mo dif.pdf, acesso em 10.10.2009, p. 10-13.

292 "Assim, qualifico como moderna essa forma de racionalidade penal que se construiu no Ocidente a partir da segunda metade do século XVIII. Assinale-se que um tal sistema de pensamento jamais é inteiramente determinado por uma causalidade material externa (transformações na sociedade): a justiça penal produz o seu próprio sistema de pensamento na medida em que se constitui como um subsistema do sistema jurídico, no âmbito de um processo em que o direito se diferencia no interior do direito. Dessa maneira, o direito penal moderno será construído e percebido como um subsistema jurídico com identidade própria. Um dos efeitos da racionalidade penal moderna será o de naturalizar a estrutura normativa inicialmente eleita pelo sistema penal. É quando tentamos pensar o sistema penal de outra forma que tomamos consciência da colonização que ele exerce sobre a nossa maneira de ver as coisas. Na lei penal, a norma de comportamento é freqüentemente formulada sob a forma de uma estrutura normativa telescópica do seguinte tipo: 'Aquele que faz $x$ pode ou deve ser punido com $y$ '. Essa estrutura é telescópica porque justapõe uma norma de sanção (permitindo ou obrigando a aplicação da pena indicada) a uma norma de comportamento (não fazer isso ou fazer obrigatoriamente aquilo). Tal construção é portanto o resultado de uma junção de dois níveis distintos de normas: de primeiro grau, referentes ao comportamento, e de segundo grau, relativas às normas de sanção6. Podemos dizer desde já que nessa estrutura telescópica adquirem particular visibilidade três tipos de penas (normas de segundo grau): a morte (ou um castigo corporal), a prisão e a multa. É a pena aflitiva muito particularmente a prisão - que assumirá o lugar dominante no auto-retrato identitário do sistema penal. (...) Ao mesmo tempo que se elege essa estrutura telescópica, privilegia-se uma linha de pensamento medieval segundo a qual é a pena aflitiva que comunica o valor da norma de comportamento e o grau de reprovação em caso de desrespeito. Dessa forma, a pena aflitiva deve ser sempre imposta e o seu quantum deve se harmonizar com o grau de afeição ao bem, indicando assim o valor da norma de comportamento" (A racionalidade penal moderna, o público e os direitos humanos. Novos Estudos CEBRAP, n. 68, março 2004, p. 40-41).

${ }_{293}$ Álvaro Pires, André Cellard e Gérald Pelletier. L'énigme des demandes..., p. 14.

294 Nesse sentido, Klaus Günther afirma que sem a disposição dos participantes de defender com fundamentos convincentes as pretensões de validades levantadas nos discursos, "não faria sentido para o ouvinte reagir ao proferimento com a assunção de uma posição crítica; ele ou ela poderia encarar esse proferimento apenas como um fato, igual a outros fatos naturais. Quando o ouvinte reage assumindo uma posição crítica, ele espera não apenas que o proponente esteja disposto a defender contra a crítica a pretensão de validade levantada por meio da proposição. O ouvinte espera, além disso, que o proponente, por sua vez, esteja em condições de se comportar de maneira crítica em relação à pretensão de validade de seu próprio proferimento, ou seja, que o outro se posicione com relação ao seu próprio proferimento de modo que este possa se tornar objeto de sua própria crítica" (Klaus Günther. Qual o conceito de pessoa..., p. 28-29). 
Uma das barreiras mais difícil de ser ultrapassada relaciona-se com a concepção do direito cujo fundamento é o exercício da força. De fato, a idéia de que o Estado deve impor seus comandos de maneira unilateral e, em caso desobediência, está autorizado a exercer a violência de maneira legítima, prevaleceu durante todo o séc. XIX e perdura nos dias atuais ${ }^{295}$.

Tradicionalmente, o direito se define pela sanção ${ }^{296}$ e a idéia de um direito desprovido de constrangimento parece absurda. Ainda que se reconheça, como fez Hart, que inúmeras normas estão desprovidas de sanção, como as que conferem poderes, pensar na prática de uma conduta definida como crime sem ter como consequência uma pena é praticamente impossível.

Entretanto, é justamente porque a norma jurídica não surge do simples jogo de interações sociais concretas, mas de um processo político definido e instituído em determinada sociedade, tornando concretas as situações abstratas através da institucionalização ${ }^{297}$, isto é, exatamente porque não há uma determinação $a$ priori do que deve ser criminalizado ou não, que se torna importante observar o jogo de diferentes protagonistas no processo de elaboração de normas, seus modos de atuar e os recursos que conseguem mobilizar para criar o direito ${ }^{298}$.

No limite, se é possível afirmar que é crime tudo aquilo que o direito diz que é e ameaça com uma pena ${ }^{299}$, também é factível pensar em um crime que não esteja associado a uma pena, pois, como afirma Álvaro Pires, "o direito-faculdade de punir exige que o indivíduo esteja em situação de poder receber a punição, mas assim como na

\footnotetext{
${ }^{295}$ Segundo Philippe Robert até o aparecimento da sociedade estatizada, a sociedade não conhece o 'penal', no sentido de uma relação que se estrutura através da imposição de uma pena. Para o autor, ainda que exista uma tradição de se reconhecer o embrião do 'penal' no período pré-estatal, a pena não se confunde com a vingança, mas é, exatamente, o seu inverso, pois se contrapõe à reação imediata, desmesurada, reativa e cega da vingança, distinguindo-se pelo fato de estar regrada (Essai de construction d'un paradigme penal. In Normes, normes juridiques, normes penales. Pour une sociologie de frontières, tomo II. Paris: L'Harmattan, 2000, p. 47-49).

${ }^{296}$ Charles-Albert Morand identifica no pensamento de vários autores essa tendência: São Tomas de Aquino definiu o direito por dois elementos, a regra e o poder coercitivo; Hobbes a exprime na fórmula "acordos sem espadas são apenas palavras"; para Bentham a lei é sinônimo de coerção; Austin, de outro lado, identifica o direito com um comando, que se caracteriza pela possibilidade de quem comanda infligir um mal ou uma pena a quem desobedece; Jhering afirma que uma regra de direito desprovida de constrangimento jurídico é um sem-sentido, como um fogo que não queima mais, uma tocha que não ilumina; para Weber uma ordem é direito se sua validade estiver garantida exteriormente pela possibilidade de um constrangimento; Kelsen, por fim, faz da sanção o objeto do dever ser (Charles-Albert Morand. Le droit néo-moderne..., p. 38-39).

${ }^{297}$ Philippe Robert. Essai de construction..., p. 61.

${ }^{298}$ Philippe Robert. Essai de construction..., p. 63.

${ }^{299}$ Philippe Robert. Essai de construction..., p. 46.
} 
recompensa isso não significa que ela seja devida no sentido próprio de uma obrigação. Dessa forma, a obrigação de obedecer à norma de comportamento não está vinculada à uma obrigação de infligir sanção, e menos ainda uma sanção aflitiva, uma vez que há outras maneiras de afirmar a norma" 300 .

$\mathrm{Na}$ presente análise, o questionamento dessa forma de pensar o direito penal não se volta apenas ao reconhecimento das limitações que impedem sua inovação, mas propõe que sua superação ocorra por meio do processo legislativo como um espaço de interação, de afirmação da democracia.

Nesse contexto, é importante afirmar que a ampliação da participação mediante a observância de um procedimento argumentativo nos debates parlamentares não significa simplesmente um processo de abertura a diferentes atores. A expansão da mídia e sua influência cada vez mais crescente, a maior importância conferida a opinião pública, o diálogo com os movimentos sociais, nada disso quer dizer, por si só, que haverá mais democracia.

A consideração da vontade do povo, por si só, não assegura a democracia, pois se não for apresentada em meio a um debate argumentativo, significa apenas que se está dando abertura ao populismo penal. No limite, pode-se afirmar que os desejos populistas de vingança, afirmados diante de acontecimentos violentos, são irracionais e só devem ser considerados quando forem testados de forma argumentativa.

A concepção do processo legislativo como um espaço onde também é possível testar os argumentos em defesa de determinada posição mais repressiva ou mais garantista de direito penal e, até mesmo, seus próprios fundamentos, é uma forma de ampliar a democracia.

Trata-se de uma maneira diferente de olhar a integração entre direito e política, de forma que ambos sejam beneficiados. O direito porque encontra no processo deliberativo argumentativo um espaço pra testar sua teoria e, no limite, rever seus fundamentos. A política porque pode, mediante a contribuição oferecida pelo direito, integrar a opinião pública mediante a realização de testes argumentativos. Não basta,

${ }^{300}$ Álvaro Pires. A racionalidade penal moderna..., p. 45. 
portanto, que essa opinião seja externada como um clamor público diante de casos midiáticos, ela precisa testada.

Quando Álvaro Pires afirma que, em razão do sistema de pensamento atual do instituto penal consubstanciado na "racionalidade penal moderna" acima mencionada, "o público torna-se um componente problemático, pois tende (nessas condições) a ser orientado a fazer regredir ou degradar o sistema", a solução não deveria ser afastar o "público" do sistema penal, já que, como afirma o próprio autor, ele tem sido cada vez mais considerado nas decisões penais ${ }^{301}$, mas aproximá-lo num espaço de intersecção entre o direito e a política, como o processo legislativo, onde seja possível verificar em que medida seus apelos se sustentam diante de um debate argumentativo.

Se, como afirma o autor, o resultado da integração do público como um componente da justiça penal, e não apenas da política, depende de como o sistema penal organiza e produz tal integração do público ${ }^{302}$, o que se propõe é que essa integração possa ocorrer no processo legislativo, nos moldes aqui apresentados.

Conforme será analisado no próximo capítulo, ao lado da pressão da opinião pública, que não deve ser assimilada sem passar pelo teste argumentativo, o processo de elaboração normativa tem sido visto cada vez mais como uma política pública, em razão das transformações analisadas acima, devendo funcionar, ainda, mediante a pressão da necessidade de avaliação de custos e resultados.

Essa duas perspectivas, portanto, se complementam, na medida em que quanto maior a quantidade de informação maior a oportunidade de testar os argumentos apresentados em defesa de determinada posição de maneira fundamentada.

\footnotetext{
${ }^{301}$ Álvaro Pires. A racionalidade penal moderna..., p. 51-52.

${ }^{302}$ Álvaro Pires. A racionalidade penal moderna..., p. 60. Para o autor, o público tem grande responsabilidade pela formulação de uma racionalidade penal que se volta à criação de novas incriminações, ao aumento de penas e o emprego do direito penal na proteção dos direitos humanos. Entretanto, se a integração é possível desde que esteja "acompanhada de um modo de pensar alternativo e demandar uma outra auto-organização normativa do sistema", o que se apresenta é a possibilidade de estabelecer essa mudança justamente ao se permitir a intersecção mencionada.
} 


\section{III - AVALIAÇÃO LEGISLATIVA}

\section{Introdução}

Tendo em vista o diagnóstico compartilhado por vários autores, de inflação legislativa, marcado pelo aumento da quantidade de leis sem observância de critérios como a coerência, concisão, clareza e uniformidade na atividade de elaboração normativa, que além de ameaçar sua qualidade, coloca em risco o respeito às regras jurídicas ${ }^{303}$, juristas de diversos países começaram a discutir, a partir dos anos 70, a possibilidade de desenvolver uma ciência de elaboração de leis ${ }^{304}$.

Apesar de suas causas serem múltiplas e variadas, esse fenômeno costuma ser atribuído, no âmbito interno do direito, à necessidade de respeitar o princípio da legalidade, pois, diante de uma sociedade cada vez mais complexa e da demanda cada vez maior pela regulamentação de fenômenos novos, aumenta a edição de dispositivos legais, que se tornam mais numerosos, precisos e detalhados, sem que haja, em paralelo, um exame mais apurado da necessidade e da oportunidade da intervenção legislativa ${ }^{305}$.

No momento em que a lei, tal como concebida pelo direito moderno ${ }^{306}$, perde uma de suas características mais importantes, a estabilidade, devendo ser continuamente ajustada, diante de uma sociedade que se transforma cada vez mais rápido, começa a surgir

\footnotetext{
${ }^{303}$ Como exemplo, ver François Dessemontet. Language et système des lois suisses. Les cahiers $d u$ droit, v. 21, n. 3 e 4, 1980, p. 581 e Pierre Issalys. Vers la systématisation des lois québécoises. Les cahiers du droit, v. 21, n. 3 e 4,1980 , p. 525-527.

${ }^{304}$ Independentemente da discussão sobre se tratar de uma ciência ou de uma arte, o tema começou a ser discutido em vários congressos. François Dessemontet menciona que o tema do Congresso da sociedade dos juristas suíços, realizado em 1974, foi a arte de legislar. Além disso, segundo o autor, o I Congresso sobre teoria da legislação ocorreu em Bonn, em 1975 (Language et système..., p. 580). Com relação aos países de língua francesa, Michel Sparer menciona a realização de três congressos sobre a redação de leis entre 1977 e 1980 nas cidades de Québec, Paris e Pointe-au-Pic (Avant-propos. Les cahiers du droit, v. 21, n. 3 e 4, 1980, p. 507). Note-se que a obra pioneira sobre o tema foi escrita pelo suíço Peter Noll em 1973, que, de acordo com Luzius Mader, foi um divisor de águas sobre o tema porque ultrapassou os limites da abordagem formal da redação de leis, mudando a ênfase para os conteúdos normativos (Legística: história e objeto, fronteiras e perspectivas. In Congresso Internacional de Legística: qualidade da lei e desenvolvimento. Belo Horizonte: Assembléia Legislativa do Estado de Minas Gerais, 2009, p. 44-45).

${ }^{305}$ Luzius Mader. L'évaluation législative..., Pour une analyse empirique des effets de la législation. Payot Lausanne, 1985, p. 3. Se a crise da lei pode ser identificada com a crise de legitimidade do Estado, na medida em que os diferentes atores sociais não se reconhecem como destinatários das leis aprovadas no Parlamento, também faz sentido explicá-la a partir do excesso de leis decorrentes de um fenômeno de super-regulação.

306 Sobre o sentido conferido a esse termo, ver capítulo II.
} 
a noção da atividade de elaboração normativa como um processo de aprendizagem do legislador ${ }^{307}$, que conta com o auxílio de métodos de revisão e avaliação.

É nesse sentido que vários autores começam a contrapor um direito mais adaptável, maleável, regulador ${ }^{308}$, que se organiza em forma de rede, ao modelo piramidal kelseniano, composto por comandos unilaterais, autoritários e centralizadores, que se comunicam entre si através de uma relação hierárquica ${ }^{309}$.

De outro lado, retomando-se a noção de emprego do direito como instrumento de formulação de políticas públicas, examinada no capítulo anterior, percebe-se que há uma tendência a aumentar o interesse em conhecer a área em que se pretende intervir, sua lógica de funcionamento, enfim, em realizar um diagnóstico preciso da situação a ser regulamentada, definindo-se os objetivos a serem alcançados e os possíveis efeitos da intervenção ${ }^{310}$.

Dessa forma, percebe-se que a proposta de avaliar as leis também se relaciona com as transformações do papel do Estado. Se no Estado liberal, associado a uma legislação geral e abstrata, é possível se satisfazer com um controle da regularidade formal dos textos normativos, no Estado intervencionista, verifica-se uma preocupação cada vez maior com o fato da lei ser realmente aplicada (efetividade), atender os objetivos a que se propõem (eficácia), e fazê-lo ao menor custo (eficiência) ${ }^{311}$.

Conforme já mencionado, essas características não se verificam apenas em alguns modelos de Estado ou em determinada época, mas se intercalam e se misturam,

\footnotetext{
${ }^{307}$ François Ost. La régulation..., p. 25.

${ }^{308}$ Ao tratar da função reguladora do direito, François Ost afirma que se trata da gestão flexível e evolutiva de um conjunto indefinido de dados em busca de um equilíbrio ao menos provisório, isto é, da ação de mecanismos destinados a manter ou restaurar, por ajustamentos sucessivos, o equilíbrio de um sistema ameaçado por perturbações (François Ost. La régulation..., p. 20-21).

${ }^{309}$ François Ost. La régulation..., p. 20. Em seu relatório anual de 1991, sobre segurança jurídica, o Conseil d'État francês utilizou a expressão "droit mou, flou, à l'état gazeaux" para designar essa realidade (François Ost. La régulation..., p. 11).

${ }^{310}$ De acordo com Jacques Chevallier, "a lei não é mais conhecida como um ato isolado e autônomo, que encontra em si mesmo sua própria coerência: reveladora de um programa de ação mais amplo, a lei constitui uma etapa e um meio de realização desse programa" (tradução livre de L'évaluation legislative: un enjeu politique. In Alain Delcamp; Jean-Louis Bergel e Alain Dupas (org.). Contrôle parlementaire et évaluation. Paris: La documentation française, 1995, p. 20).

${ }^{311}$ François Ost e Benoît Jadot. Introduction générale. In François Ost e Benoît Jadot (dir.). Élaborer la loi aujourd'hui, mission impossible? Bruxelles: Facultés Universitaires Saint-Louis, 1999, p. 9. Curiosamente, se de um lado esse modelo de Estado suscita a importância da avaliação, sua falência pode ser identificada com o panorama de crise da lei, em razão do excesso de regulação, que acabou dificultando a comunicação entre o legislador e seus destinatários.
} 
num processo contínuo de reformulação do direito, que vai se adaptando, adotando algumas propostas de mudança e repelindo outras. É por isso que se mantêm ainda que o modelo de Estado intervencionista possa ser considerado superado e outras formas de atuação estatal confiram novas marcas ao direito.

O importante, portanto, é observar como a lógica da formulação e implementação de políticas públicas começa a ser incorporada no processo de elaboração de leis.

Essas mudanças atingem a concepção tradicional da lei, que associa eficácia à validade, conferindo-lhe legitimidade $a b$ initio. Ao deixar de se beneficiar de um postulado de eficácia, decorrente apenas de sua existência no ordenamento jurídico, a lei passa a ser questionada sobre seus efeitos concretos, o grau de aplicação de seus dispositivos e os resultados que permite alcançar ${ }^{312}$.

Ao lado do aumento crescente da produção legislativa, identifica-se, portanto, uma tendência a desenvolver uma técnica de aperfeiçoamento qualitativo da estrutura e da formulação das leis, que, do ponto de vista formal, é traduzida pelos esforços em melhorar os aspectos relacionados à redação, terminologia e estilo das leis, e, sob o viés material, pela tentativa de resolver as dificuldades de sua aplicação, ao se revelarem inadequadas à realização do objetivo pretendido ou produzirem efeitos não pretendidos.

Nesse contexto, a ciência da legislação é vista como uma proposta inovadora, que se debruça sobre a dinâmica das leis com a preocupação de sanar as deficiências de uma doutrina que tende a separar o direito da realidade social, na medida em que realiza um diagnóstico com base em uma análise empírica ${ }^{313}$.

Isso porque, sua principal função é fornecer respostas teóricas e gerais à questão de saber como os problemas sociais podem ser resolvidos pela edição de normas

\footnotetext{
${ }^{312}$ Jacques Chevallier. L'évaluation legislative..., p. 14.

${ }^{313}$ Luzius Mader. L'évaluation législative..., p. 14. Segundo o autor, o enfoque dos autores é muito diverso diante do diagnóstico de crise da lei. Alguns são mais pragmáticos e preocupam-se apenas em encontrar as receitas para confeccionar boas leis. Outros adotam posturas mais teóricas e procuram estabelecer ligações com a teoria do direito e a dogmática jurídica e se propõem a explicar a natureza e a função do processo legislativo e das leis. Outros, ainda, enfocam a análise empírica e mostram o fosso que existe entre o modelo de conduta previsto ao legislador e os componentes reais ou entre o objetivo visado pelo legislador e o resultado prático.
} 
jurídicas e como as situações sociais podem ser influenciadas no sentido buscado pelo legislador ${ }^{314}$.

Trata-se, portanto, de substituir a concepção de um legislador hipoteticamente racional pela de um legislador que realmente adota critérios racionais de escolha dos fatos a serem regulamentados e das opções a sua disposição para executar essa tarefa ${ }^{315}$.

Ocorre, portanto, o abandono da premissa de que as leis, desde que elaboradas de acordo com um formato pré-determinado, produziriam automaticamente os resultados pretendidos, mediante a compreensão da necessidade de avaliar seus efeitos reais e analisar o impacto que provoca sobre a sociedade ${ }^{316}$.

Diante da hipótese de que esse diagnóstico praticamente não ocorreu no Brasil e de que ainda são muito incipientes as discussões sobre o tema nesse país ${ }^{317}$, pretende-se verificar em que consiste a tarefa de avaliar e analisar o impacto das leis a partir da experiência internacional, numa tentativa de propor uma reflexão sobre a necessidade de incorporar esses mecanismos no processo legislativo brasileiro.

\section{A Legística}

Do ponto de vista teórico, a preocupação com a tarefa de elaboração das leis e seus efeitos têm sido objeto de análises que buscam sistematizar o conhecimento que vem sendo produzido sobre o tema.

Trata-se de uma preocupação que perpassa diversas áreas, como o direito e as ciências sociais, podendo, portanto, ser considerada interdisciplinar. A tentativa de

\footnotetext{
${ }^{314}$ Luzius Mader. La législation: objet d'une science en devenir? In Zenon Bankowski et al. La science de la legislation. Paris: PUF, 1988, p. 11.

${ }^{315}$ A racionalidade, nesse contexto, reporta-se a concepção de um homem que identifica, inicialmente, as finalidades que pretende alcançar e os valores aos quais adere, para, em seguida, estabelecer uma ordem de prioridade entre eles e, então, determinar as possíveis formas que dispõe para agir, considerando as consequências que eventualmente cada uma delas pode produzir. A partir daí, é possível comparar as diferentes possibilidades e escolher a que parece mais adequada de acordo com os objetivos que deseja atingir (Luzius Mader. L'évaluation législative..., p. 99).

${ }^{316}$ Luzius Mader. Legística: história e objeto..., p. 46.

${ }^{317}$ Uma exceção a essa lacuna no Brasil é a dissertação de mestrado apresentada na Universidade de São Paulo por Natasha Schmitt Caccia Salinas, cujo título é Avaliação legislativa no Brasil: um estudo de caso sobre as normas de controle das transferências voluntárias de recursos públicos para entidades do terceiro setor.
} 
compilar todas as abordagens possíveis do tema vem sendo reconhecida com um campo de conhecimento denominado Legística ${ }^{318}$.

Um dos autores que mais se dedica ao tema, Luzius Mader, desdobra essa nova forma de abordar a legislação em várias disciplinas, dentre as quais, a sociologia legislativa, a técnica legislativa, o processo legislativo, a metodologia legislativa e a teoria da legislação ${ }^{319}$.

A sociologia, por exemplo, ao voltar-se ao estudo do processo de formulação das leis, desenvolve-se em dois sentidos: com o intuito de fornecer ao legislador informação sobre as condições e as consequências de suas ações ou como espaço de produção de conhecimento sobre a legislação, examinando todos os aspectos do fenômeno legislativo ${ }^{320}$.

A técnica legislativa ou legística formal tem por objeto os aspectos formais da legislação, relacionados à redação dos textos legais. A questão principal que procura responder é como exprimir um conteúdo normativo em forma de lei, adotando como parâmetro o princípio da inteligibilidade e compreensibilidade geral ${ }^{321}$.

Não se trata de uma preocupação apenas com a estrutura interna das normas, mas também com a existência de sistematicidade entre elas, ou seja, da relação das normas com o conjunto do ordenamento jurídico. Isto é, no limite, não são questões puramente formais, pois a preocupação com a linguagem que será utilizada, por exemplo, pressupõe um conhecimento sobre o emprego de noções jurídicas indeterminadas ${ }^{322}$.

\footnotetext{
${ }^{318}$ Muitos autores discutem se se trata de uma ciência ou de uma arte de legislar. Luzius Mader utiliza o termo "legisprudência" para expressar de modo mais apropriado o caráter dessa nova abordagem, que, segundo o autor, "baseia-se em elementos acadêmicos e teóricos mas também tem em conta preocupações práticas; combina, por um lado, a ciência (a 'ciência' da elaboração de leis) mas também, por outro lado, 'arte' e habilidade (a 'arte' de elaboração da lei)" (Avaliação prospectiva e análise de impacto legislativo: tornam as leis melhores? Legislação: Cadernos de Ciência da Legislação, n. 42/43, jan.jun. 2006, p. 178).

${ }^{319}$ Luzius Mader. L'évaluation législative..., p. 18.

${ }^{320}$ Luzius Mader. L'évaluation législative..., p. 19.

${ }^{321}$ Luzius Mader. L'évaluation législative..., p. 20.

${ }^{322}$ Luzius Mader. L'évaluation législative..., p. 21. Em outro artigo, o autor separa da técnica legislativa a preocupação com as escolhas materiais de conteúdo da norma, denominando a disciplina que se ocupa dessa tarefa de formulação legislativa ou aspectos linguísticos e comunicacionais (Luzius Mader. Avaliação prospectiva..., p. 179). Ao avançar mais sobre o tema, afirma que "a técnica legislativa trata dos aspectos formais da legislação: os diferentes tipos de atos normativos, as instituições jurídicas, a estrutura formal dos atos normativos e a forma por meio da qual novas leis são introduzidas ou integradas no arcabouço normativo preexistente", enquanto a redação legislativa trata da "forma de expressar o teor normativo do conteúdo das leis, concernente especificamente aos aspectos lingüísticos" (Luzius Mader. Legística: história e objeto..., p. 47).
} 
O processo legislativo corresponde não só às disposições constitucionais e legais que regulamentam o processo de elaboração e aprovação de leis, mas também, para além do aspecto formal, a maneira como sua organização determina, em certa medida, a capacidade de análise e de ação do legislador, influenciando e provocando alterações no conteúdo de suas decisões ${ }^{323}$.

A metodologia legislativa ou legística material é essencialmente hermenêutica, preocupando-se com a interpretação das normas, cujo objetivo é desenvolver a capacidade do legislador de identificar e selecionar demandas, com o intuito de abandonar uma postura meramente reativa ${ }^{324}$.

Trata-se de propor uma forma metódica de se elaborar as leis e desenvolver ferramentas de uso prático que facilitem o avanço nas diferentes etapas de análise, considerando-se todas as opções possíveis e suas consequências, tanto antes da aprovação da lei, quanto depois, mediante a monitoração de sua execução e a avaliação de seus efeitos reais ${ }^{325}$.

Nesse âmbito, encontram-se os estudos dos motivos e dos fatores que influenciam o legislador, os quais permitem identificar em que medida sua atuação é mera reação a um fato social polêmico ou é fruto de uma reflexão mais profunda sobre as consequências da proposta de regulamentar determinado fato.

Por fim, a teoria da legislação tem a função de fornecer uma explicação global ao fenômeno legislativo, que considere o conjunto de relações recíprocas entre a legislação e a vida social ${ }^{326}$. Trata-se de apresentar reflexões críticas e avaliar constantemente as funções da legislação em determinada sociedade ${ }^{327}$.

Para facilitar a análise, o processo de decisão política no âmbito legislativo (metodologia legislativa ou legística material) é dividido em diversas fases, de acordo com critérios institucionais ou funcionais.

\footnotetext{
${ }^{323}$ Luzius Mader. L'évaluation législative..., p. 22.

${ }^{324}$ Luzius Mader. L'évaluation législative..., p. 23-24.

${ }^{325}$ Luzius Mader. Legística: história e objeto..., p. 46-47.

${ }^{326}$ Luzius Mader. L'évaluation législative..., p. 26.

${ }^{327}$ Luzius Mader. Legística: história e objeto..., p. 49. Nesse artigo, o autor menciona, ainda, mais duas áreas de interesse da Legística, a comunicação, que trata da informação e divulgação de conhecimento sobre a norma, e a gestão de projetos legislativos (Legística: história e objeto..., p. 48-49).
} 
Desse ponto de vista, sua decomposição abarca as seguintes etapas: a definição do problema; a elaboração de uma solução, tendo em vista os meios e instrumentos à disposição; a adoção da legislação, isto é, sua redação e promulgação formal; sua implementação; e a avaliação de seus efeitos, o que pode ocasionar o retorno a qualquer uma das fases anteriores e a adaptação da legislação. Todas essas fases contam com a participação de atores sociais, públicos ou privados ${ }^{328}$.

De acordo com Jean-Daniel Delley e Alexandre Flückiger, duas condições são necessárias para que se verifique a existência de fato de um problema, que se identificam como dois elementos constitutivos, um analítico e um normativo. Em primeiro lugar, a presença de um estado de tensão, a percepção de uma distância entre a situação real e a situação desejada. Em segundo lugar, uma imputação de causalidade, pois sem evidenciar as causas que são responsáveis pelo problema, não é possível intervir. Segundo os autores, essa fase de definição do problema é muito importante, pois é comum que se revele, na prática, apenas uma percepção do problema, fazendo com que o impulso que o legislador possui de agir substitua o exame objetivo da situação. É por isso que essa primeira fase deve servir para a aquisição de um conhecimento mais aprofundado da realidade, a partir de dados confiáveis ${ }^{329}$.

A identificação dos instrumentos a disposição para resolver o problema e alcançar a situação desejada permite que o legislador faça uma lista exaustiva das possibilidades e reflita sobre suas escolhas. No âmbito do direito penal, por exemplo, essa tarefa pode fazer com que ele perceba a existência de outras possibilidades além da pena para coagir o comportamento não desejado.

Nesse sentido, Jean-Daniel Delley afirma que "no momento de proceder à escolha dos instrumentos, o legista é ameaçado pelo perigo da rotina. Sua familiaridade com certos tipos de instrumento o conduz freqüentemente a preferir confiar nas medidas que ele já conhece em vez de procurar o instrumento ou a conjugação de instrumentos suscetíveis de influenciar mais eficazmente os comportamentos com vistas a atingir o objetivo desejado. Os instrumentos checados adquirem uma espécie de força normativa que limita a possibilidade de escolha e impede arranjos novos. O fenômeno é

\footnotetext{
${ }^{328}$ Luzius Mader. L'évaluation législative..., p. 35.

${ }^{329}$ La légistique: une élaboration méthodique de la législation. In Roland Drago (dir.). La confection de la loi. Paris: Presses Universitaires de France, 2005, p. 86.
} 
particularmente visível, por exemplo, no que tange ao direito penal: quando um comportamento penalmente condenável ganha corpo, o legislador escolhe prioritariamente o aumento da pena" 330 .

Entre a definição do problema e a elaboração de uma solução, é importante determinar os objetivos que se quer alcançar. De um lado, porque o legislador só deve intervir quando estiver bem claro que a situação real é substancialmente distinta da situação desejada e só a identificação dos seus objetivos permite ilustrar essa questão. De outro lado, apenas quando a situação desejada estiver visivelmente identificada é que se torna possível determinar as estratégias e os meios de ação para alcançar os objetivos previstos $^{331}$.

A tarefa não é fácil. Muitas vezes o conflito de interesses impede o legislador de identificar claramente seus objetivos, optando, como solução para o acordo, em descrever de maneira bem geral a situação desejada. Em outras situações, especialmente quando se trata da regulamentação de domínios novos como a tecnologia, o legislador simplesmente não sabe o que deseja alcançar e não consegue, mais uma vez, identificar os objetivos que pretende atingir ${ }^{332}$.

A necessidade, por exemplo, de aprofundar o conhecimento da realidade, buscando informações confiáveis, durante a fase de definição do problema, permite que o impulso que motiva o legislador seja relativizado, deixando em aberto a possibilidade do problema não existir ou sua solução decorrer da adoção de outras medidas, que não a legislativa, renunciando-se a intervenção normativa ${ }^{333}$.

Assim, a definição do problema de forma correta auxilia a tarefa de identificação da solução, pois muitos deles não se resolvem mediante a intervenção governamental. É preciso sempre considerar outras formas de solução de conflitos e essa reflexão sustenta um processo mais aberto de tomada de decisão, que se vale de forma mais criativa dos instrumentos de políticas públicas a disposição.

\footnotetext{
330 Jean-Daniel Delley. Pensar a lei. Introdução a um procedimento metódico. Cadernos da Escola do Legislativo, Belo Horizonte, v. 7, n. 12, jan./jun. 2004, p. 136.

${ }^{331}$ Jean-Daniel Delley e Alexandre Flückiger. La légistique..., p. 88. Segundo os autores, construir um sistema de objetivos significa estabelecer uma hierarquia, ordenar os níveis entre eles, que vão dos mais abstratos aos mais concretos, perguntando-se sempre o porquê e o como.

332 Jean-Daniel Delley e Alexandre Flückiger. La légistique..., p. 89.

${ }^{333}$ Jean-Daniel Delley e Alexandre Flückiger. La légistique..., p. 86.
} 
Percebe-se, portanto, que não basta observar apenas os procedimentos formais que regulam o processo de elaboração das leis, é preciso respeitar todas as etapas descritas acima para que, no limite, a lei seja aceita e cumprida por seus destinatários.

Como forma de observar essas etapas e melhorar a qualidade das leis, diversas medidas podem ser adotadas, dentre as quais a avaliação legislativa, compreendida como o “conjunto de análises baseadas no emprego de métodos científicos, relativas à execução e os efeitos dos atos legislativos" 334 .

$\mathrm{Na}$ realidade, se, conforme afirma François Ost, o tratamento do direito nada mais é do que um processo de aprendizagem, por tentativa e erro ${ }^{335}$, esses métodos funcionam como mecanismos capazes de esclarecer e auxiliar essa atividade.

Conforme será analisado no próximo tópico, não se trata apenas de medir os efeitos da lei, mas também de analisar as causas das transformações da realidade social, identificando-se em que medida a intervenção legal foi responsável pelas mudanças verificadas na sociedade ${ }^{336}$.

a) avaliação legislativa

A avaliação legislativa pode ocorrer em dois momentos: antes ou depois da adoção da legislação. No primeiro caso, é preciso observar os eventuais problemas que podem ocorrer em razão da aplicação da lei, isto é, seus efeitos virtuais, configurando-se a avaliação prospectiva ou ex ante. No segundo, a proposta é examinar os efeitos reais das normas na sociedade, realizando-se uma avaliação retrospectiva ou ex post ${ }^{337}$.

\footnotetext{
${ }^{334}$ Tradução livre de Luzius Mader. L'évaluation législative..., p. 44. Para o autor, a avaliação legislativa se distingue das análises que não são baseadas em critérios científicos, assim como da simples colheita de dados estatísticos. Segundo ele, "o resultado de uma apreciação puramente impressionista - por exemplo, de um político ou um jornalista - dos efeitos de uma lei não são menos pertinentes do que os que resultam de uma longa pesquisa que corresponda aos critérios de cientificidade da disciplina a que diz respeito; mas são de outra natureza" (tradução livre de Luzius Mader. L'évaluation législative..., p. 45). Charles-Albert Morand afirma que a avaliação é ou deve ser metódica porque a explicação da produção de efeitos deve se apoiar em hipóteses verificáveis, assim como os efeitos devem ser analisados com o auxílio de métodos comprovados das ciências sociais e, em alguns casos, das ciências naturais (Charles-Albert Morand. Formes e fonctions de l'évaluation législative. In François Ost e Benoît Jadot (dir.). Élaborer la loi aujourd'hui, mission impossible? Bruxelles: Facultés Universitaires Saint-Louis, 1999, p. 210).

${ }^{335}$ François Ost. La régulation..., p. 25.

${ }^{336}$ Charles-Albert Morand. Formes e fonctions..., p. 210.

${ }^{337}$ Luzius Mader. L'évaluation législative..., p. 46.
} 
É importante mencionar que a avaliação não se resume a dizer se uma lei é boa ou ruim, de fazer um juízo de valor, mas de analisar, a partir de critérios científicos, se certos meios são apropriados para atingir determinados fins ${ }^{338}$.

A avaliação prospectiva busca maximizar as chances de sucesso das intervenções estatais ao propor a análise cuidadosa da realidade que pretendem incidir e calcular seus possíveis êxitos e os efeitos perversos que podem provocar.

Já a avaliação retrospectiva serve para colocar um fim em uma medida que se revelou inadequada ou para propor correções na lei diante das disfunções que se revelam em razão de sua aplicação prática ${ }^{339}$.

Ao tratar da "obrigação de saber" que se impõe ao legislador na tarefa de elaboração da lei, François Ost a desdobra em duas vertentes: o "dever prever", que se traduz em técnicas de simulação diversas, e o "dever rever", representado por técnicas de avaliação retrospectiva ${ }^{340}$.

A avaliação prospectiva deve ser realizada a partir de técnicas que permitam verificar o grau de adequação das medidas escolhidas aos objetivos visados. Trata-se de uma previsão sobre o futuro a partir de dados empíricos, observáveis em situações do passado ou simuladas no presente.

Jean-Daniel Delley distingue dois grandes tipos de avaliação prospectiva, as que se apóiam em métodos de análise ou em métodos de teste. A primeira se aplica a partir da identificação de um conjunto de medidas, com o intuito de conhecer aspectos particulares de uma proposta legislativa; já a segunda tenta prever o que ocorreria se um projeto de lei tivesse entrado em vigor ${ }^{341}$.

Dentre os métodos de análise, o direito comparado é um dos mais simples e fornece informações sobre as experiências de outros países. Da mesma forma, é possível se

\footnotetext{
${ }^{338}$ Charles-Albert Morand. Les exigences de la méthode législative et du droit constitutionnel portant sur la formation de la législation. Droit et Société, n. 10, 1988, p. 410.

339 Charles-Albert Morand. L'évaluation legislative ou l'irrésistible ascension d'un quatrième pouvoir. In Alain Delcamp; Jean-Louis Bergel e Alain Dupas (org.). Contrôle parlementaire et évaluation. Paris: La documentation française, 1995, p. 137-138. Segundo o autor, essas duas formas de avaliação contribuem para controlar a inflação legislativa, na medida em que buscam auxiliar a tarefa de produção do direito em quantidade menor, mas de melhor qualidade.

${ }^{340}$ François Ost. La régulation..., p. 26.

${ }^{341}$ Jean-Daniel Delley. Pensar a lei..., p. 140.
} 
apoiar na busca de resultados de pesquisas já realizadas sobre leis que tratem de problemas semelhantes ${ }^{342}$.

Entretanto, para prever de maneira mais precisa as consequências da adoção de determinada medida, é melhor recorrer a métodos estatísticos mais sofisticados, como é o caso da análise de custo-benefício ${ }^{343}$, ainda que a escolha desse recurso seja preferível quando se trata de questões relacionadas à política econômica ou físcal ${ }^{344}$.

Da mesma forma, mesmo que a base da análise de custo-benefício reflita exatamente dois dos principais objetivos da avaliação legislativa, quais sejam, assegurar que os benefícios de uma ação governamental justifiquem seus custos e que a opção escolhida represente a maximização dos benefícios e a minimização dos custos, não quer dizer que outros tipos de análise não possam ser utilizados para avaliar as leis ${ }^{345}$.

Dentre os métodos de teste, podem ser citadas técnicas como a simulação, o jogo e o teste prático. A primeira pressupõe a construção de um modelo, com o auxílio de um computador, que reproduz os elementos essenciais da situação real; a segunda possui o mesmo método e a mesma intenção da simulação, mas introduz jogadores reais em uma dinâmica que representa a realidade; na terceira, as autoridades competentes agem como se o projeto de lei já estivesse em vigor e o aplicam hipoteticamente aos casos concretos ${ }^{346}$.

A experimentação legislativa situa-se entre a avaliação prospectiva e a retrospectiva e consiste na adoção temporária de uma lei com o objetivo de observar como

\footnotetext{
${ }^{342}$ Jean-Daniel Delley e Alexandre Flückiger. La légistique..., p. 93.

${ }^{343}$ A análise custo-benefício consiste num "método de avaliação de uma realidade ou proposta que permite uma comparação explícita desta com proposta alternativas, incluindo entre as alternativas a manutenção do 'status-quo', utilizando uma métrica comum, normalmente expressa em valores monetários”. Esse tipo de análise não se limita apenas aos custos e benefícios diretos e imediatos, nem aos que apresentam peso econômico significativo ou de fácil cálculo; também não se restringe ao cálculo de custos e benefícios econômicos, mas sociais, culturais ou psicológicos (Nuno Garoupa. Limites ideológicos e morais à avaliação económica da legislação. Legislação: Cadernos de Ciência da Legislação, n. 42/43, jan.-jun. 2006, p. 88).

${ }_{344}^{34}$ Jean-Daniel Delley e Alexandre Flückiger. La légistique..., p. 93.

345 Relatório Regulatory impact analysis: best practices in OCDE countries, p. 8, disponível em http://www.oecd.org/dataoecd/21/59/35258828.pdf, acesso em 12.11.2010.

${ }^{346}$ Luzius Mader. L'évaluation législative..., p. 47. Para o autor, a primeira técnica apresenta a dificuldade de adequar um modelo a uma situação real, sendo inevitável que ocorra uma redução da complexidade do problema, entretanto parece ser mais vantajosa do que a segunda, na medida em que permite o estudo de sistemas muito complexos e interdependentes, que só o computador é capaz de controlar, possibilitando, assim, uma análise comparativa das alternativas de ação que se oferecem ao legislador. Além disso, a terceira técnica permite testar a praticidade de um ato legislativo num contexto muito próximo da situação futura de aplicação, mas sem que os verdadeiros destinatários intervenham, evitando, assim, os inconvenientes relacionados à construção de um modelo abstrato. No entanto, não abandona o risco de ficar muito focada nos problemas já conhecidos diante da impossibilidade de prever novas situações que decorrem da realidade (L'évaluation législative..., p. 47).
} 
será sua aplicação na prática e os efeitos que produz, ao invés de adotá-la de forma definitiva $^{347}$.

O legislador recorre normalmente a essa técnica quando sente dificuldade de legislar, seja pela complexidade da matéria, seja porque precisa enfrentar problemas delicados, portadores de forte conflituosidade social, valendo-se da experimentação com o intuito de reduzir a incerteza ou alcançar um consenso maior sobre a aplicação da lei ${ }^{348}$.

Trata-se de um dos exemplos de avaliação que mais expõe a precariedade assumida pelo direito. Ainda que, de certa maneira, toda lei seja uma experiência, no momento em que o legislador condiciona expressamente sua manutenção em vigor a um processo explícito de revisão que deve ocorrer necessariamente ao final do prazo determinado, esse aspecto fica ainda mais evidente ${ }^{349}$.

As leis experimentais caracterizam-se, portanto, por serem limitadas pelo tempo ou pelo campo de sua aplicação ${ }^{350}$, a partir de uma restrição geográfica ou populacional. Além disso, devem prever a realização de uma avaliação, assegurando-se que a lei só será mantida como apresentada inicialmente ou com modificações se forem considerados os resultados desse estudo e desde que seja editada uma nova lei ${ }^{351}$.

\footnotetext{
${ }^{347}$ L'évaluation législative..., p. 47-48.

${ }^{348}$ Jacques Chevallier. Raport introductif. Revue de la recherche juridique, n. 4, 1994, p. 1091.

${ }^{349}$ François Ost. La régulation..., p. 27. Apesar de incomum no Brasil, diversos países adotam esse tipo de lei. Nos EUA, essas leis ficaram conhecidas como sunset laws. Ainda que nesse país a função estabilizadora do direito não seja assegurada por leis positivas, consideradas instrumentos conjunturais do governo, nos anos 70 multiplicaram-se as leis com cláusulas de ab-rogação, que só eram afastadas se os seus defensores provassem a necessidade de sua manutenção (François Ost. La régulation..., p. 28). Ao contrário dos países europeus, que adotaram leis experimentais com vocação a se perpetuarem, na medida em que a avaliação servia mais para eliminar as disfunções que apareceram na sua aplicação, nos EUA a lógica de adoção desse tipo de lei é essencialmente gerencial, cujo objetivo é a deflação jurídica e organizacional (Jacques Chevallier. L’évaluation legislative..., p. 24).

${ }^{350}$ Diante da possibilidade de um direito de aplicação limitada, restrito geograficamente ou setorialmente, não respeitar a necessidade de generalidade da lei e ofender, portanto, o princípio da legalidade, o Conselho Constitucional e o Conselho de Estado francês já se manifestaram diversas vezes, no sentido de reconhecer a constitucionalidade das leis experimentais desde que respeitem certas condições, como a necessidade de explicitar a sua natureza, seu conteúdo e seus limites, prever sua avaliação e determinar sua duração (Vanessa Perrocheau. L'éxpérimentation, un nouveau mode de création législative. Revue française des affaires sociales, ano 54, n. 1, jan.-mar. 2000, p. 21-25).

${ }^{351}$ Sobre as características das leis experimentais, ver Vanessa Perrocheau. L'éxpérimentation..., p. 14-20. Segundo a autora, a aplicação limitada, a presença de uma claúsula prevendo a avaliação no texto da lei, assim como a necessidade de adotar um novo texto legal caso a lei se perpetue ou seus dispositivos se generalizem, são as três características fundamentais das leis experimentais (L'éxpérimentation..., p. 19-20).
} 
b) análise dos efeitos da lei

Para apreender os efeitos de uma lei é preciso dividir o problema geral em uma série de problemas parciais. De acordo com Luzius Mader, os mais importantes deles podem ser esboçados com a ajuda de questões específicas: o comportamento real corresponde ao modelo normativo? Qual é o papel das autoridades responsáveis pela aplicação da lei na concretização das decisões legislativas? A legislação atende o objetivo pretendido? O resultado pode ser obtido ao menor custo? $\mathrm{O}$ resultado real difere das consequências desejadas ou atendidas? ${ }^{352}$

Cada uma dessas questões corresponde a um critério específico de análise, dentre os quais o autor distingue, respectivamente, a efetividade, a implementação, a eficácia, a eficiência e o impacto da legislação ${ }^{353}$.

A efetividade compreende dois aspectos: trata-se de saber, em primeiro lugar, se os comportamentos ou situações reais observáveis na realidade correspondem aos que foram previstos na legislação e, em segundo lugar, se esses comportamentos ou situações realmente ocorreram em razão da sua observância ${ }^{354}$.

Assim, analisar a efetividade de uma lei significa comparar as condutas reais dos destinatários ao modelo normativo de comportamento, de forma a estabelecer a taxa de observação ou não de uma norma legal, e examinar em que medida essa conformidade não ocorreu em razão de outros fatores ${ }^{355}$.

Com relação à implementação da lei ${ }^{356}$, é preciso esclarecer que não se trata apenas de atos mecânicos, mas do processo de concretização das decisões legislativas. Esse processo diz respeito a tentativa de se alcançar a conscientização dos setores

\footnotetext{
${ }^{352}$ Luzius Mader. L'évaluation législative..., p. 55.

${ }^{353}$ Luzius Mader. L'évaluation législative..., p. 55.

${ }^{354}$ Luzius Mader. L'évaluation législative..., p. 56-57.

${ }^{355}$ Luzius Mader. L'évaluation législative..., p. 56-57. Para uma visão mais aprofundada sobre os conceitos de efetividade, eficácia e eficiência, sob o viés da sociologia jurídica, ver Mauricio García Villegas. La eficacia simbólica del derecho. Santafé de Bogotá: Uniandes, 1993.

${ }^{356}$ Os autores de língua francesa utilizam o termo "mise en œuvre" para designar essa sucessão de atos que não se limitam à aplicação ou execução mecânica das leis. Segundo Luzius Mader, esses estudos de "mise en œuvre" nascem no seio da "policy analysis" americana, e por muito tempo foram renegados em relação aos estudos relacionados aos problemas de impacto e de eficácia da lei, que se contentavam em constatar as carências de certos programas de ação legislativos, especialmente em matéria de política social e no domínio da educação. É no momento em que esses estudos começam a se preocupar em explicar as causas das falhas desses programas que a atenção se volta à organização e as atividades dos institutos encarregados da sua aplicação (L'évaluation législative..., p. 65).
} 
governamentais e administrativos responsáveis pela aplicação das leis como garantia de observância das decisões adotadas pelo legislador ${ }^{357}$.

Esses estudos, de análise de efetividade e de avaliação do grau de implementação da lei, se diferenciam em relação aos tipos de normas que podem ser considerados e a ótica adotada. Enquanto o primeiro se volta ao comportamento dos particulares e normalmente focaliza as normas de direito civil e penal, o segundo tem como foco o alcance de finalidades mais imediatas e precisas, principalmente de direito público, cuja aplicação implica em regras gerais de intervenção de autoridades executivas ou administrativas ${ }^{358}$.

Os fatores determinantes de implementação da lei são: a natureza do problema, as características do instrumento de regulação e as particularidades do sistema de atores envolvidos ${ }^{359}$.

É na tensão entre a situação real e a situação desejada que se identifica um problema a ser resolvido pelo legislador. Essa percepção e articulação perante o legislador é tarefa dos atores sociais em jogo, em razão dos valores aos quais aderem e dos interesses que defendem. Não basta, entretanto, apresentar o ponto de vista desses atores sobre o problema por eles identificado, é preciso, conforme visto, fazer um esforço de abstração, afastando-se de percepções muito marcadas por interesses particulares ${ }^{360}$.

A intervenção estatal pode se revestir de formas diversas. $\mathrm{O}$ instrumento a ser escolhido pelo legislador depende das suas intenções, seja regular de forma global ou pontual determinada questão, seja eliminar as causas do problema ou apenas seus sintomas e efeitos $^{361}$.

Jean-Daniel Delley divide os instrumentos à disposição de acordo com seus modos de funcionamento: (i) instrumentos de tipo prescritivo ou coercitivo, aos quais são associadas sanções, impondo comportamentos; (ii) instrumentos de incentivo, que visam estimular, não impor, comportamentos, por estímulo financeiro, positivo ou negativo, informação, formação ou pressão regulamentar; (iii) instrumentos de coordenação; (iv)

\footnotetext{
${ }^{357}$ Luzius Mader. L'évaluation législative..., p. 64-65.

${ }^{358}$ Luzius Mader. L'évaluation législative..., p. 65.

${ }^{359}$ Luzius Mader. L'évaluation législative..., p. 66.

${ }^{360}$ Luzius Mader. L'évaluation législative..., p. 67.

${ }^{361}$ Luzius Mader. L'évaluation législative..., p. 67.
} 
fornecimento de bens e serviços públicos pelo Estado; (v) procedimentos que regulem as relações entre diferentes grupos sociais ou que garantam a determinados grupos a participação em certas decisões; e (vi) instrumentos de parceria $^{362}$.

A rede de atores é formada por múltiplos órgãos estatais ou paraestatais, empresas ou particulares, organizações privadas como os partidos políticos, os grupos de interesses, a opinião pública ou o público em geral. O peso dos atores, sua capacidade de influenciar o processo de concretização e transformação da legislação varia em função dos recursos a sua disposição ${ }^{363}$.

A legislação é considerada um instrumento que se destina à resolução de um problema. Sendo assim, deve atender certos objetivos e a tarefa de verificar se eles foram de fato atingidos relaciona-se com os estudos de eficácia da norma. Trata-se da comparação entre o resultado realmente alcançado e o que era desejado, verificando-se em que medida há uma adequação dos meios escolhidos aos objetivos pretendidos ${ }^{364}$.

Só é possível verificar se uma lei é eficaz ou não se ela tiver sido efetivamente aplicada. A correspondência entre o modelo normativo de comportamento e a conduta real não constitui um fim em si, mas é apenas uma condição, um meio destinado a permitir a realização de um objetivo determinado ${ }^{365}$.

É essencial, portanto, que o legislador determine quais são os objetivos que pretende atingir com a adoção da lei, entretanto, não é muito comum que isso ocorra. Em geral, o legislador descreve suas intenções, mas não esclarece quais metas deseja alcançar.

Para que esses objetivos fiquem explícitos, a análise deve considerar, em primeiro lugar, o discurso pré-legislativo, isto é, as aspirações dos principais atores sociais envolvidos, que se expressam na mídia, nos trabalhos legislativos preliminares e nos debates parlamentares.

Em seguida, é preciso examinar o discurso normativo, isto é, o texto legal, capaz de traduzir certas finalidades do legislador e, mais ainda, marcar a passagem das pretensões setoriais, específicas de diversos atores sociais, para uma finalidade coletiva.

\footnotetext{
362 Jean-Daniel Delley. Pensar a lei..., p. 128-134.

${ }^{363}$ Luzius Mader. L'évaluation législative..., p. 69.

${ }^{364}$ Luzius Mader. L'évaluation législative..., p. 77.

${ }^{365}$ Luzius Mader. L'évaluation législative..., p. 77.
} 
Por fim, o avaliador deve considerar a aplicação da legislação, apta a esclarecer, completar ou modificar a conclusão extraída da análise dos discursos prélegislativo e legislativo ${ }^{366}$.

É raro que a lei possua um objetivo único, claramente enunciado e relativamente concreto ${ }^{367}$. A análise da eficácia de uma lei encontra, portanto, diversas dificuldades, dentre as quais, a de se deparar com objetivos formulados de forma vaga e abstrata, a existência de objetivos implícitos ou não revelados, assim como de objetivos que se modificam de acordo com as circunstâncias ${ }^{368}$.

O critério da eficiência ultrapassa a análise da conformação dos comportamentos sociais ao modelo normativo e da adequação desse modelo aos objetivos pretendidos, isto é, da comparação entre uma situação de fato e uma situação desejada ou exigida, inserindo-se um elemento novo, de verificação dos recursos disponíveis para atender os resultados pretendidos pela lei ${ }^{369}$.

Nesse sentido, uma intervenção legislativa "é considerada plenamente eficiente se um resultado determinado é obtido com o mínimo de meios, ou se, com os meios dados, um grau máximo de realização do resultado buscado é atendido" ${ }^{370}$.

A eficiência pode ser considerada sob o aspecto econômico, mas também político e social e, em geral, é examinada do ponto de vista do Estado. Assim, o critério econômico de eficiência não deve substituir a decisão política do legislador, entretanto, na medida em que coloca em evidência certas consequências das decisões legislativas, não pode ser por ele ignorado ${ }^{371}$.

Por fim, o impacto das leis diz respeito ao conjunto de efeitos pertinentes da legislação, isto é, os comportamentos e os fatos ou situações relacionadas entre si pela ligação causal com uma determinada decisão legislativa ${ }^{372}$.

\footnotetext{
${ }^{366}$ Luzius Mader. L'évaluation législative..., p. 79-80.

${ }^{367}$ Luzius Mader. L'évaluation législative..., p. 80.

${ }^{368}$ Luzius Mader. L'évaluation législative..., p. 80-81.

${ }^{369}$ Luzius Mader. L'évaluation législative..., p. 82.

370 Luzius Mader. L'évaluation législative..., p. 83. O autor destaca que a minimização dos meios e a maximização do resultado são situações extremas, pois, na realidade, a eficiência, que se exprime em porcentagem e não em números absolutos, é parcial. Assim, o julgamento sobre a eficiência de uma lei é necessariamente relativo.

${ }^{371}$ Luzius Mader. L'évaluation législative..., p. 84.

${ }^{372}$ Luzius Mader. L'évaluation législative..., p. 90.
} 
c) programas de avaliação legislativa

Conforme mencionado, diante do diagnóstico de crise da lei, diversos países começaram a desenvolver e institucionalizar medidas para solucionar os problemas dele decorrentes, como é o caso da avaliação legislativa.

Um dos primeiros documentos a tratar desse tema foi produzido pela OCDE (Organisation for Economic Co-operation and Development) em 1995, recomendando aos seus Estados membros a superação da ideia de que uma política de desregulamentação era a melhor solução para resolver os problemas da inflação legislativa, e a adoção de uma política de qualidade da produção normativa, a ser desenvolvida por todos, de acordo com suas especificidades ${ }^{373}$.

Para tanto, a organização elaborou uma checklist a ser observada antes da tomada de decisões sobre a regulamentação normativa. A lista é formada por dez perguntas: (i) o problema está definido de maneira correta? ; (ii) a interferência do governo se justifica? ; (iii) a regulamentação é a melhor forma de intervenção estatal? ; (iv) existe uma base legal/constitucional que sustente a regulamentação pretendida? ; (v) qual o nível apropriado de intervenção governamental? ; (vi) os benefícios da regulamentação justificam os custos? ; (vii) a distribuição dos efeitos da regulamentação na sociedade é transparente? ; (viii) a regulamentação é clara, consistente, compreensiva e acessível a todos os usuários? ; (ix) todas as partes interessadas tiverem a oportunidade de apresentar seus pontos de vista? ; (x) como a observância da regulamentação pelos destinatários será alcançada? ${ }^{374}$

\footnotetext{
${ }^{373}$ Ver Marta Tavares de Almeida. A contribuição da Legística para uma política de legislação: concepções, métodos e técnicas, p. 8. Congresso Internacional de Legística - qualidade da lei de desenvolvimento, Belo Horizonte-MG, disponível em http://www.almg.gov.br/eventos/Legistica/imagens/Marta Tavares.pdf, acesso em 06.11.2010 e François Ost. La régulation..., p. 11-12.

374 The OECD reference checklist for regulatory decision-making, 1995, disponível em http://www.oecd.org/officialdocuments/displaydocumentpdf?cote=OCDE/GD $\% 2895 \% 2995 \&$ doclanguage $=\mathrm{e}$

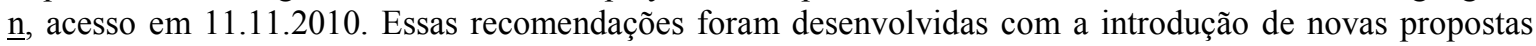
em dois relatórios elaborados posteriormente, em 1997 (ver "The 1997 OECD Report to Ministers", disponível em http://www.oecd.org/dataoecd/17/25/2391768.pdf, acesso em 23.11.2010) e 2005 (ver "The 2005 OECD Guiding principles for regulatory quality and performance", disponível em http://www.oecd.org/dataoecd/24/6/34976533.pdf, acesso em 23.11.2010 e "The 2005 APEC-OECD Integrated checklist on regulatory reform", disponível em http://www.oecd.org/dataoecd/41/9/34989455.pdf, acesso em 23.11.2010).
} 
Alguns países europeus, como a Bélgica, a Suíça ${ }^{375}$ e a França, assumiram posição de destaque na tarefa de discutir e implementar instrumentos de avaliação, com o intuito de simplificar e melhorar a qualidade das leis.

É importante mencionar que nesses países há uma tradição de supremacia do Poder Legislativo, pois não há controle de constitucionalidade a posteriori das leis, ainda que na França, em 2010, tenha ocorrido uma reforma, instituindo a possibilidade de um juiz singular encaminhar ao Conselho Constitucional um pedido de análise da constitucionalidade de uma lei. Assim, como não há um controle posterior, a preocupação com a qualidade e adequação ao sistema jurídico das leis ocorre durante o processo legislativo, o que talvez explique a importância que a avaliação legislativa assumiu nesses países.

$\mathrm{Na}$ Bélgica, por exemplo, diversos projetos de lei foram apresentados no Senado, ao longo dos anos 90, com o intuito de regulamentar a avaliação legislativa ${ }^{376}$.

Em um relatório sobre o tema, o Senado belga apresentou dez mandamentos para uma boa legislação ${ }^{377}$ : (i) a lei deve promover a segurança jurídica; (ii) a lei deve assegurar a igualdade jurídica; (iii) a regra deve ser formulada de maneira que seja possível remediar as consequências não desejadas de sua aplicação concreta no caso individual; (iv) a lei deve observar o princípio da subsidiariedade; (v) os objetivos da lei devem ser definidos de forma clara; (vi) a lei deve observar o princípio da necessidade; (vii) a lei só deve ser elaborada se existirem garantias de sua aplicação na prática, isto é, desde que haja um suporte social suficiente e sua aplicação não configure um encargo muito alto aos aparelhos judiciário e administrativo; (viii) a lei deve possibilitar o alcance dos objetivos

\footnotetext{
${ }^{375}$ A Suíça apresenta um clima favorável a institucionalização de mecanismos de avaliação legislativa, pois, entre outros fatores, o fato de se tratar de uma democracia direta contribuiu para a tentativa de elaboração de leis compreensíveis e acessíveis por todos (Luzius Mader. Avaliação dos efeitos da legislação - a situação actual na Suíça. Legislação: Cadernos de Ciência da Legislação, n. 33/34, jan.- jun. 2003, p. 139).

${ }^{376}$ Ver Rapport « Projet de loi instituant une procédure d'évaluation législative », Sénat de Belgique, session de 1998-1999, p. 6, http://www.senate.be/www/webdriver?MItabObj=pdf\&MIcolObj=pdf\&MInamObj=pdfid\&MItypeObj=appli cation/pdf\&MIvalObj=16780922, acesso em 06.11.2010. De acordo com esse relatório, "o velho adágio 'a ninguém é permitido ignorar a lei' não há mais nenhum valor real. A Bélgica conta com mais de 15.000 leis penais. Não há um belga que nunca cometeu alguma infração ou que não cometerá jamais, a menos que ele seja um eremita. $\mathrm{O}$ belga que se recusa a se sentir culpado não pode fazer nada para dar sentido a sua vida. Mas a perda de transparência e de acessibilidade da regulamentação vem acompanhada de uma perda de aplicabilidade, que corroí cada vez mais a credibilidade do poder normativo. A expansão desenfreada de nosso arsenal normativo é uma das causas - e não a menor - do fosso que separa o cidadão da política" (Tradução livre, p. 10).

${ }^{377}$ Rapport « Projet de loi instituant une procédure d'évaluation législative »..., p. 11.
} 
buscados (efetividade) com o mínimo de meios possível (eficácia); (vi) a gravidade dos inconvenientes ou obstáculos causados pela lei não podem ser desproporcionais ao objetivo perseguido ou ao resultado alcançado; (x) o legislador só pode regulamentar efetivamente o comportamento se ele conseguir utilizar a regra na realidade complexa das relações sociais existentes ${ }^{378}$.

Esses mandamentos podem ser identificados com os sete princípios que foram apresentados no relatório do Conselho Europeu de 2000 (Relatório Mandelkern): real necessidade da norma a ser adotada; proporcionalidade (equilíbrio entre as vantagens da legislação e as limitações/obrigações que impõe aos cidadãos); subsidiariedade (escolha do meio menos custoso em relação aos objetivos que se pretende alcançar); transparência do procedimento de elaboração da norma; responsabilidade (determinação dos efeitos da norma, monitoramento de sua execução); acessibilidade e simplicidade ${ }^{379}$.

Na França, uma lei de 1996 criou o Office parlementaire d'évaluation de la législation, cuja função é reunir informações e realizar estudos para avaliar a adequação da legislação às situações as quais ela se aplica, além de assumir a missão de simplificação da legislação ${ }^{380}$.

É importante mencionar ainda que países que adotam o sistema de common law, como os EUA, a Inglaterra e o Canadá foram pioneiros na adoção de medidas de planejamento e revisão do sistema de regulação normativa ${ }^{381}$.

Inicialmente, as reformas empreendidas nesses países relacionavam-se de forma direta à tentativa de mesurar os impactos dos atos normativos nas atividades

\footnotetext{
${ }^{378}$ Rapport « Projet de loi instituant une procédure d'évaluation législative »..., p. 12-13.

${ }^{379}$ Marta Tavares de Almeida. A contribuição da Legística..., p. 9.

${ }^{380} \mathrm{http}: / /$ www.senat.fr/commission/legislation/index.html, acesso em 06.11.2010.

381 Sobre os EUA, ver a Executive order 12.291, de 1981, no âmbito do governo Regan (http://www.archives.gov/federal-register/codification/executive-order/12291.html, acesso em 11.11.2010), e a Executive order 12.866, de 1993, elaborada no governo Clinton (http://www.whitehouse.gov/sites/default/files/omb/inforeg/eo12866.pdf, acesso em 11.11.2010). O Office of information and regulatory affairs, que pertence ao Office of management and the budget, na Casa Branca, é o órgão responsável pela análise de todas as medidas que apresentem algum impacto econômico (http://www.whitehouse.gov/omb/inforeg default, acesso em 11.11.2010). Sobre o Reino Unido, ver http://www.cabinetoffice.gov.uk/making-legislation-guide/impact assessment.aspx, acesso em 11.11.2010. No Canadá, o governo federal realiza periodicamente a revisão de leis, inclusive para evitar que haja conflito entre as leis federais e das províncias, muitas vezes contraditórias (Alain Delcamp; Jean-Louis Bergel e Alain Dupas (org.). Contrôle parlementaire et évaluation. Paris: La documentation française, 1995, p. 179-186).
} 
empresariais e foram aos poucos sendo assimiladas como uma necessidade em outras áreas de intervenção ${ }^{382}$.

A avaliação legislativa foi deixando de ser prioridade apenas em alguns países com a adoção, a partir de 2002, no âmbito da União Européia, de um sistema de avaliação de impacto através das Impact assessment guidelines ${ }^{383}$.

Na realidade, a avaliação legislativa, na União Européia, está inserida em um programa maior, denominado Better regulation ${ }^{384}$, cujo objetivo é melhorar a qualidade das propostas legislativas a nível europeu, tornando-as mais compreensíveis através de processos de decisão mais transparentes.

Consequentemente, vários países adotaram mecanismos de avaliação de impacto da regulamentação (Regulatory Impact Assessment ou RIA), que consiste num processo de avaliação dos impactos positivos e negativos de uma medida reguladora ${ }^{385}$, podendo ser realizado antes ou depois de sua entrada em vigor, ainda que em diversos casos, haja críticas sob a forma como o programa foi implementado na prática ${ }^{386}$.

\footnotetext{
${ }^{382}$ Mark Courtney. Quadro de uma política para a melhoria da qualidade da acção normativa. Legislação: Cadernos de Ciência da Legislação, n. 33/34, jan.-jun. 2003, p. 109-110.

${ }^{383} \mathrm{http}: / /$ ec.europa.eu/governance/impact/index en.htm, acesso em 11.11.2010.

384 http://ec.europa.eu/governance/better regulation/index en.htm, acesso em 11.11.2010. Na União Européia, a discussão sobre o tema começou no âmbito do Conselho Europeu, que criou um grupo de trabalho, denominado Grupo Mandelkern, cujo relatório, apresentado em 2000, anunciou os princípios fundamentais a serem observados para a melhoria da qualidade legislativa (necessidade, proporcionalidade, subsidiariedade, transparência, responsabilidade, acessibilidade e simplicidade), bem como seus instrumentos (consulta/participação, avaliação de impacto, programas de simplificação e acesso à legislação, revisões periódicas e consolidação da legislação). Sobre o tema, ver Relatório Mandelkern. Legislação: Cadernos de Ciência da Legislação, n. 29, out.-dez. 2000.

${ }^{385}$ Esse termo mais amplo é utilizado tanto para indicar a denominada legislação primária (leis em sentido estrito) quanto a legislação secundária ou normas infralegais (regulamentações em geral).

${ }^{386}$ Em Portugal, apesar dos esforços para realizar estudos de avaliação legislativa, diversas críticas têm sido destinadas ao modelo adotado, pois, apesar das reformas efetuadas, manteve um sistema essencialmente formal, que confundiu e assimilou de maneira deficiente as boas práticas que vinham sendo realizadas em outros países (Nuno Garoupa e Guilherme Vasconcelos Vilaça. A prática e o discurso da avaliação legislativa em Portugal. Legislação: Cadernos de Ciência da Legislação, n. 44, out.-dez. 2006, p. 6 e p. 23-24). O projeto português se estruturou através da criação da Comissão para Simplificação Legislativa, em 9 de março de 2001, e do lançamento dos programas Prace (Programa de Reestruturação da Administração Central do Estado) e Simplex (Programa de Simplificação Administrativa e Legislativa), que buscaram, em sentido mais amplo, racionalizar a administração pública (Nuno Garoupa e Guilherme Vasconcelos Vilaça. A prática e o discurso..., p. 10-11). A Comissão para Simplificação Legislativa foi criada com o intuito de "identificar áreas da legislação existente que devem ser objecto de intervenção, elaborar estudos e emitir recomendações com vista à simplificação e melhoria da qualidade da legislação e regulamentação; analisar e propor medidas que visam a maior acessibilidade da legislação, designadamente através da consolidação, compilação ou codificação; analisar e apresentar situações em que se justifique a deslegalização ou desregulamentação, incentivando nestas áreas a auto-regulação ou outras formas de actuação; estudar os procedimentos legislativos e institucionais vigentes com vista à propositura de novas regras de simplificação, relativamente à produção de novos actos normativos" (http://www.csl.gov.pt/, acesso em 12.11.2010).
} 
Mais do que uma forma de controlar a inflação legislativa e melhorar a qualidade das leis produzidas, nos países europeus a RIA é reconhecida como um meio de assegurar a rentabilidade econômica, pois ao transformar as leis num produto racional mais do que no produto do mero arbítrio do legislador, reduz a incerteza e a insegurança jurídica, incentivando a confiança no poder pública e a realização de investimentos ${ }^{387}$.

d) dificuldades relacionadas à avaliação

A avaliação legislativa, em qualquer uma das modalidades possíveis de serem executadas, não é tarefa fácil. Em primeiro lugar, porque nem todas as leis apontam de maneira precisa os objetivos que pretendem realizar. Algumas, por exemplo, tem uma função essencialmente simbólica ${ }^{388}$. Outras são tão vagas e imprecisas que se torna impossível identificar quais são seus objetivos ${ }^{389}$.

Ademais, diversas normas não pretendem modificar comportamentos, mas estabelecer princípios ${ }^{390}$, ou servir apenas para fornecer um paradigma para os comportamentos sociais sem visar a concretização de objetivos precisos ${ }^{391}$.

Por outro lado, é muito difícil estabelecer relações de causalidade entre as normas e as mudanças de comportamento, que ocorrem, geralmente, em ambientes complexos ${ }^{392}$.

\footnotetext{
${ }^{387}$ Nuno Garoupa e Guilherme Vasconcelos Vilaça. A prática e o discurso..., p. 12. De acordo com o relatório da OCDE sobre boas práticas nos países da organização, "experience in OECD countries shows that, properly designed and applied, RIA can improve the effectiveness and efficiency of governments and can help address broader issues of competitiveness and economic performance in innovative and globalising economies. RIA by itself is not a sufficient basis for decisions; instead, RIA is best used as a guide to improve the quality of political and administrative decision-making, while also serving important political values of openness, public involvement and accountability" (Regulatory impact analysis: best practices in OCDE countries, p. 7, disponível em http://www.oecd.org/dataoecd/21/59/35258828.pdf, acesso em 12.11.2010).

${ }^{388}$ Consequentemente, a eficácia de uma lei pode ser analisada do ponto de vista instrumental, relacionado a sua capacidade de produzir determinados efeitos, ou simbólico, em razão do impacto que o direito produz como discurso (Mauricio García Villegas, El poder social del derecho..., p. 82). Ver, sobre as diversas possibilidades de análise da eficácia das leis, Carolina Dzimidas Haber. A eficácia da lei penal..., p. 130-144.

${ }^{389}$ Charles-Albert Morand. Formes e fonctions..., p. 211.

${ }^{390}$ Charles-Albert Morand. Formes e fonctions..., p. 216.

${ }^{391}$ Jean-Daniel Delley. Pensar a lei..., p. 103. Segundo o autor, é o caso dos códigos processuais, do Código Civil e do Código Penal, isto é, de leis que não visam transformar profundamente uma realidade social, articulando objetivos e os meios para alcançá-los. A necessidade de avaliar os efeitos das leis e corrigi-las em função dos resultados verificados seria indispensável apenas para essas leis mais dinâmicas, com objetivos mais claros.
} 
Assim, uma avaliação só é possível se o avaliador se contentar com uma visão parcial da realidade, sem falar que, quanto mais tiver a pretensão de se aprofundar na realidade, mais cara será a avaliação realizada ${ }^{393}$, além de demorar mais tempo, que invariavelmente não coincide com o tempo da agenda política ${ }^{394}$.

A tarefa de avaliação pode, ainda, ser ameaçada por dois perigos: o amadorismo de quem a realiza e a manipulação dos resultados pela autoridade pública que a recebe ${ }^{395}$.

Para evitar esses problemas e assegurar que a prática da avaliação se generalize, Charles-Albert Morand afirma ser necessária a conjugação de três fatores: uma vontade política forte, o desenvolvimento de técnicas e de conhecimentos sobre o tema e a decisão de investir recursos financeiros altos ${ }^{396}$.

Nesse sentido, ao analisar as iniciativas dispersas de política de avaliação legislativa em Portugal, Marta Tavares de Almeida considera essencial para consolidar esse projeto: a assunção de um compromisso político; a afetação de recursos humanos e materiais; a adoção das normas de qualidade legislativa da OCDE na nota justificativa dos projetos de lei; a criação de um organismo central que dinamize a realização de avaliação da legislação, colaborando com o órgão que detém a iniciativa legislativa; a capacitação de formação de especialistas no tema; e o estabelecimento de contatos institucionais com países e organizações internacionais que já tenham experiência nessa matéria ${ }^{397}$.

\footnotetext{
392 De acordo com Natasha Salinas, analisar as causas dos comportamentos dos destinatários das normas é das tarefas mais complexas, por se tratar de fenômenos sociais, sobre os quais não se pode chegar a conclusões absolutas e inequívocas, e sim apenas a probabilidades acerca do nexo de causalidade existente entre os objetivos declarados no enunciado normativo e os efeitos produzidos pela legislação (Natasha Schmitt Caccia Salinas. Avaliação legislativa no Brasil: um estudo de caso sobre as normas de controle das transferências voluntárias de recursos públicos para entidades do terceiro setor. Dissertação de Mestrado. Universidade de São Paulo, 2008, p. 43).

${ }^{393}$ Segundo Ulrich Karpen, na Alemanha os custos de uma avaliação ex ante profunda varia entre 25.000 e 155.000 euros, chegando por vezes a custar 255.000 euros (Avaliação legislativa - a experiência alemã. Legislação: Cadernos de Ciência da Legislação, n. 33/34, jan.-jun. 2003, p. 13).

${ }^{394}$ Charles-Albert Morand. Formes e fonctions..., p. 218-219.

${ }^{395}$ Charles-Albert Morand. Formes e fonctions..., p. 221.

${ }^{396}$ Charles-Albert Morand. Formes e fonctions..., p. 224. Segundo o autor, na Suíça a vontade política se manifestou através da criação de várias instâncias de avaliação no seio da administração, do governo e do parlamento e pela multiplicação de cláusulas de avaliação nas leis. O desenvolvimento de técnicas e conhecimentos ocorreu de duas maneiras, através do lançamento de um vasto programa nacional de pesquisa sobre os efeitos das medidas estatais, sendo que os resultados acabaram formando o quadro conceitual da avaliação, e pela formação de avaliadores, versados nos métodos das ciências sociais, preparados para executar suas funções tanto nas instâncias estatais quanto no setor privado.

${ }^{397}$ Marta Tavares de Almeida. Avaliação da legislação em Portugal. Legislação: Cadernos de Ciência da Legislação, n. 33/34, jan.-jun. 2003, p. 106.
} 
É importante, ainda, cotejar a avaliação legislativa e a avaliação de políticas públicas. Se a lei passa a ser considerada como um dos diversos instrumentos ao serviço de uma política pública, a proposta de isolá-la desse contexto pode deformar a análise dos efeitos das políticas públicas em si, mesmo que essas avaliações sejam individualizadas em razão de suas especificidades ${ }^{398}$.

De qualquer forma, a maioria dos estudiosos do tema admite que essas dificuldades não devem levar a renúncia do projeto de avaliação, o qual pode auxiliar, e muito, o processo de tomada de decisões políticas ${ }^{399}$.

Isso porque, conforme afirma Charles-Albert Morand, "a avaliação não é concebida como um julgamento peremptório sobre os efeitos de uma lei ou de uma política pública, mas, sobretudo como uma arena que permite enriquecer o debate democrático e, também, como um instrumento de aprendizagem" 400.

A avaliação deve, portanto, ser realizada, ainda que somente em relação a leis que regulamentam certas matérias, onde se apresentam dados quantitativos e contingentes, como as áreas econômica, fiscal e social, e desde que não seja nem muito onerosa, nem muito lenta ${ }^{401}$.

Nesse sentido, Luzius Mader afirma que a avaliação legislativa não deve se configurar como uma rotina, mas somente ser utilizada estrategicamente e de acordo com o caso concreto. Não pode significar, portanto, apenas o cumprimento de obrigações burocráticas, de forma mecânica, devendo "ocorrer apenas quando possa oferecer um meio

\footnotetext{
${ }^{398}$ Charles-Albert Morand. L'évaluation legislative..., p. 140. O autor defende que a avaliação da legislação não deve ser suplantada pela avaliação de políticas públicas. Isso porque a lei é o fundamento de validade último do todos os meios a serviço da realização dos objetivos que ela se propõe a atender, assim, é preciso distinguir, na avaliação, a realização dos objetivos imperativamente fixados pela lei e os outros objetivos políticos, que não devem obrigatoriamente ser realizados. Assim, a lei não é apenas fonte de legitimidade de todas as ações estatais que são realizadas para que ela possa ser aplicada, mas também assegura a unidade dessas ações. A lei é o lugar central de articulação mais ou menos harmoniosa entre os objetivos de uma política pública e os instrumentos previstos para atendê-la. Além disso, não é possível ignorar que o direito possui uma lógica de funcionamento própria e a avaliação legislativa deve assegurar o respeito aos valores por ele consagrados (Charles-Albert Morand. L'évaluation legislative..., p. 140-142).

${ }^{399}$ Ver Charles-Albert Morand. Formes e fonctions..., p. 219-220 e Ulrich Karpen. Avaliação legislativa..., p. 13-14.

${ }^{400}$ Charles-Albert Morand. Formes e fonctions..., p. 220.

${ }^{401}$ Jean-Louis Bergel. Problématique et méthode de l'évaluation legislative. In Alain Delcamp; Jean-Louis Bergel e Alain Dupas (org.). Contrôle parlementaire et évaluation. Paris: La documentation française, 1995, p. 197.
} 
genuinamente conveniente para melhorar o fundamento da tomada de decisão a um custo razoável e justificável" ${ }^{402}$.

Entretanto, antes de qualquer investimento nessa área, é preciso pensar na preparação e aceitação dos envolvidos, pois é comum que os políticos critiquem a interferência dos especialistas na decisão democrática e os especialistas critiquem a falta de cientificidade dos políticos, que geralmente apresentam seus objetivos de forma incompleta e aleatória ${ }^{403}$. Assim, sem a conscientização dos atores envolvidos sobre a importância do tema de nada adianta estabelecer regras de avaliação.

A possibilidade de avaliar o processo legislativo não pode significar que as decisões ali tomadas devem apenas se submeter a um método científico de análise, independentemente da participação e da consideração de todos os interesses envolvidos. A proposta é, na verdade, complementar, na medida em que contribui com mais e melhor informação, permitindo que o legislador possa decidir conhecendo bem as condições e as consequências de suas intervenções ${ }^{404}$.

A avaliação legislativa, portanto, não se confunde com o controle parlamentar, a não ser que se trate de um autocontrole, isto é, da postura adotada pelo Parlamento de se interrogar sobre os efeitos da legislação que pretende adotar ${ }^{405}$, isto é, de reforçar sua responsabilidade no processo decisório, aumentando seu compromisso com a necessidade de argumentação e fundamentação de suas propostas. Não se deve esquecer, portanto, que cada um dos atores envolvidos possui objetivos próprios e a divergência de interesses é inerente ao processo político de decisão ${ }^{406}$.

\footnotetext{
${ }^{402}$ Luzius Mader. Avaliação dos efeitos da legislação..., p. 138.

${ }^{403}$ Jean-Louis Bergel. Problématique et méthode..., p. 199. É para evitar essa divergência que o autor sugere que a avaliação seja confiada a um órgão autônomo e independente das pressões de grupos políticos.

${ }^{404}$ Luzius Mader. L'évaluation législative..., p. 100-101.

405 Jacques Chevallier. Rapport introductif. Revue de la recherche juridique, n. 4, 1994, p. 1088.

406 "Levando em consideração as forças dos grupos de pressão e as influências políticas que cercam o processo decisório inerente à produção legislativa, as quais não se enquadram nos processos racionais e científicos propostos pela ciência da legislação, as limitações dos estudos sobre produção legislativa parecem óbvias. O fortalecimento de uma ciência da legislação não se destina, por essa razão, a superar os contingentes irracionais da produção legislativa. Esta visa, tão somente, a encarar essa contingência com certa dignidade” (Natasha Schmitt Caccia Salinas. Avaliação legislativa no Brasil..., p. 24-25).
} 
Nesse sentido, o "julgamento avaliativo" deve se dissociar do "julgamento decisório", permitindo que o conhecimento produzido no primeiro seja apropriado pelo conjunto de atores políticos e sociais e não confundido com o segundo ${ }^{407}$.

Diante desse quadro, duas medidas podem ser adotadas para auxiliar o processo de decisão política: a criação de um corpo de especialistas em leis e a institucionalização da avaliação das leis ${ }^{408}$.

Para Jean-Daniel Delley, a tarefa do especialista em elaboração de leis é diferente da forma como o legislador, e mesmo o jurista e o sociólogo do direito, analisam as leis. Se o jurista investiga a finalidade das leis, para aplicá-las ao caso concreto, e o sociólogo do direito busca identificar, nos objetivos apresentados pelo legislador, outros que não estão explícitos ou que decorrem do conflito entre norma e realidade, o "legista" deve partir dos fins e objetivos que lhe são apresentados para elaborar uma estratégia de ação que possibilite a realização desses objetivos ${ }^{409}$.

Sob o aspecto do órgão competente por realizar a avaliação, os países que adotaram oficialmente a obrigação de avaliar as leis apresentam modelos diversos, atribuindo essa função ora ao Poder Executivo, ora ao Poder Legislativo ${ }^{410}$. De qualquer forma, diversos autores acreditam que a avaliação será mais bem realizada se for centralizada em um único órgão ${ }^{411}$.

Alguns autores, inclusive, defendem que sejam criadas estruturas especializadas e independentes, tendo em vista a necessidade de realizar estudos baseados em métodos rigorosos de análise ${ }^{412}$.

Nesse caso, fica claro que os especialistas em avaliar as leis não se confundem com os legisladores, auxiliando-os, ao garantir que suas decisões serão tomadas tendo em vista todas as informações importantes relacionadas ao caso sobre o qual pretendem legislar.

\footnotetext{
${ }^{407}$ Jacques Chevallier. Rapport introductif..., p. 1088.

${ }^{408}$ François Ost e Benoît Jadot. Introduction générale..., 1999, p. 8.

409 Jean-Daniel Delley. Pensar a lei..., p. 115-116.

${ }^{410}$ Charles-Albert Morand. L'évaluation legislative..., p. 146-147.

411 Ver Nuno Garoupa. Improving legislation - a note of pessimism. Legislação: Cadernos de Ciência da Legislação, n. 50, out.-dez. 2009.

${ }^{412}$ Ver, nesse sentido Jacques Chevallier. Rapport introductif. Revue de la recherche juridique, n. 4, 1994, p. 1089.
} 
e) fundamentação constitucional da avaliação legislativa

Com relação à fundamentação constitucional da avaliação legislativa, algumas decisões emblemáticas sobre o tema foram proferidas pela Corte Constitucional da Alemanha, ao declarar que a observância do método legislativo é condição de validade da lei ${ }^{413}$.

Com o intuito de compensar as incertezas que existem sobre os efeitos da lei, diversas obrigações foram impostas ao legislador. Na fase preparatória, a Corte demandou que o legislador fizesse uma investigação completa dos fatos pertinentes, analisasse as diferentes variáveis da legislação e apresentasse uma avaliação prospectiva dos efeitos que poderiam ser produzidos de acordo com a variável escolhida.

Ou seja, em geral, a Corte exige que o legislador observe constantemente os efeitos produzidos pela lei e que a corrija em função dos efeitos detectados ${ }^{414}$.

Além disso, qualificou de objetivo de valor constitucional a acessibilidade e inteligibilidade da lei, ou seja, esses requisitos não são apenas direitos subjetivos, mas valores objetivos de efetividade e limitação de direitos ${ }^{415}$.

Os objetivos de valor constitucional estão implicitamente consagrados pela Constituição e resultam da observância e interpretação de diversos princípios constitucionais explícitos. A acessibilidade e inteligibilidade da lei, por exemplo, decorrem de uma série de dispositivos da Declaração de Direitos do Homem e do Cidadão, tais como o reconhecimento da igualdade perante a lei $\left(\operatorname{art.} 6^{\circ}\right.$ ), pois os cidadãos que não conhecem ou não compreendem a lei se encontram em situação desigual em relação aos que conhecem; a ideia de que os direitos não podem ser efetivamente garantidos se os cidadãos não conhecerem seus direitos (art. 16); a noção de que apenas a lei pode delimitar a

\footnotetext{
${ }^{413}$ Conforme explicitado por Charles-Albert Morand, o caráter inovador da decisão na Alemanha advém do fato da Corte Constitucional, ao invés de reexaminar o trabalho do legislador, com o intuito de verificar em que medida a elaboração da lei observou os princípios constitucionais relacionados com a avaliação, ter optado por impor ao legislador, de forma geral, determinadas exigências de método legislativo e controlar seu respeito (Charles-Albert. Les exigences de la méthode législative et du droit constitutionnel portant sur la formation de la législation. Droit et Société, n. 10, 1988, p. 412-413).

${ }^{414}$ François Ost. La régulation..., p. 27 e Charles-Albert Morand. L'évaluation legislative..., p. 143.

415 Pierre de Montalivet. La “juridicisation” de la légistique”. In Roland Drago (dir.). La confection de la loi. Paris: Presses Universitaires de France, 2005, p. 100.
} 
liberdade dos cidadãos (art. $4^{\circ}$ ); e de que nada que não seja proibido pela lei pode ser impedido e ninguém pode ser obrigado a fazer algo que não queira (art. $\left.5^{\circ}\right)^{416}$.

Nesse sentido, a Corte Constitucional alemã impôs ao legislador a observância de quatro grandes princípios de método legislativo: a consideração prévia de todos os fatos que têm relação com a lei; a obrigação de analisar todos os dados e de ponderar as alternativas à regulamentação; a realização de uma avaliação prospectiva; a obrigação de corrigir a lei caso se verifique a produção de efeitos não previstos ou que coloquem em perigo os direitos fundamentais ${ }^{417}$.

Em primeiro lugar, portanto, o legislador deve observar esses princípios, tendo em vista o respeito aos direitos fundamentais. A lei pode, ainda, ser declarada inconstitucional se não observar os princípios da igualdade, quando promove alguma desigualdade em razão dos efeitos que produz, e da proporcionalidade.

O princípio da proporcionalidade se desdobra em dois subprincípios, da aptidão e da necessidade. O primeiro exige que uma lei tenha condições de atingir os objetivos a que se propôs, o que pode ser verificado mediante o emprego de uma avaliação prospectiva. O segundo exige que, entre os diversos meios oferecidos ao legislador para atingir os objetivos pretendidos, a escolha seja do menos grave aos interesses privados envolvidos ${ }^{418}$.

Verifica-se, portanto, que, do ponto de vista constitucional, é possível encontrar justificativas para a realização de avaliações legislativas, como forma de assegurar, ainda que indiretamente, a observância de direitos individuais e a ampliação da aplicação das garantias.

\section{f) avaliação legislativa e o direito}

Como uma tentativa de perpetuar sua estrutura, assentada especialmente no princípio da legalidade e ameaçada pela inflação normativa, o direito recorre a diversos instrumentos, como a delegação da tarefa de regulamentar os casos mais complexos a

\footnotetext{
${ }^{416}$ Pierre de Montalivet. La "juridicisation”..., p. 104.

${ }^{417}$ Charles-Albert Morand. Les exigences..., p. 412-413.

${ }^{418}$ Charles-Albert Morand. L'évaluation legislative..., p. 144-145.
} 
normas infralegais, diante da dificuldade de elaborar uma lei exaustiva e completa, e o recurso a noções jurídicas indeterminadas ${ }^{419}$.

É frequente, portanto, o embate entre os que defendem a manutenção do sistema jurídico pensado como uma tentativa de contraposição ao Estado absolutista e à concentração de poderes nas mãos do soberano, mediante a limitação da intervenção do Estado na esfera da liberdade e da integridade física individuais, e aqueles que propõem mudanças estruturais nessa forma de conceber o direito, ao questionar a capacidade de adaptação desse modelo tradicional à atual conjuntura social, política e econômica.

Nesse contexto, como uma tentativa de enfrentar essa realidade, a proposta desse trabalho é propor uma reformulação na forma de conceber essa relação. Se de um lado, é preciso manter o respeito a garantias, historicamente conquistado, de outro é preciso dialogar com as propostas de revisão, ainda mais porque não é possível ignorar que a legislação vigente é fruto de um debate democrático orientado à edição de uma lei legitimamente promulgada e que, nesse contexto, ainda que uma lei represente uma afronta à lógica e sistematicidade do ordenamento jurídico, não é possível ignorá-la se tiver sido aprovada pelo Parlamento.

A possibilidade de avaliar a legislação permite que seus resultados possam influenciar um processo concreto de decisão, obrigando o legislador a justificar melhor sua escolha, o que contribui para criar melhores condições ao processo de tomada de decisão democrática e amplia o diálogo entre os diferentes atores envolvidos ${ }^{420}$.

As consultas prévias, por exemplo, permitem que diferentes pontos de vista sejam apreciados no processo de elaboração da lei, possibilitando não só sua adequação à diversidade de opiniões, mas também evitando os custos de sua revisão pouco tempo depois de sua entrada em vigor, além de aumentar as chances de observância pelos destinatários, uma vez que a eles foi dada a oportunidade de participar e escolher a melhor opção.

\footnotetext{
${ }^{419}$ Luzius Mader. L'évaluation législative..., p. 112. No direito penal a dificuldade de lidar com essa contradição é bem clara. A criação de tipos penais cada vez mais abertos, a proteção de bens jurídicos supraindividuais, o recurso a penas cada vez mais severas, a incriminação de mera violação de deveres, a proliferação dos crimes de perigo, a utilização frequente de tipos penais omissivos próprios e impróprios, são alguns dos desafios que vem sendo enfrentados como uma contradição em relação aos princípios e garantias relacionadas ao processo de construção das normas penais.

${ }^{420}$ É nesse sentido que François Ost afirma que "a obrigação de saber (prever, rever) adquire cada vez mais a forma de uma obrigação de consultar e de negociar" (François Ost. La régulation..., p. 29).
} 
Quanto maior a oportunidade de participar da elaboração da lei ${ }^{421}$, maiores são as chances de reduzir as contradições e de apropriação do seu conteúdo, na medida em que o processo de identificação e avaliação dos problemas ocorre de forma mais clara.

De outro lado, diante da frustração de não vislumbrar a resolução dos problemas que pretendia enfrentar com a apresentação de determinada proposta, o legislador começa a se preocupar mais com a execução das medidas que adotou para tentar resolvê-los ${ }^{422}$.

Um exemplo pode servir para ilustrar essa questão. Considerando que a maioria das propostas apresentadas no Congresso Nacional buscam o recrudescimento dos tipos penais, ora criando novos crimes, ora aumentando a pena dos já existentes ${ }^{423}$, a avaliação dos efeitos dessas proposições poderia servir para verificar se o Poder Executivo conseguiria corresponder a demanda por mais vagas no sistema penitenciário.

Além disso, avaliações prévias poderiam contribuir para verificar qual é a melhor medida a ser adotada diante de um fato que poderia ser tipificado como crime. Muitas vezes, a melhor solução não é criminalizar a conduta, mas adotar outros instrumentos de política pública, capazes de reduzir sua incidência, sem recorrer ao meio mais gravoso à disposição do Estado.

Diante de um fato que cause comoção pública pela violência com que foi praticado, ao invés de reagir com a apresentação de propostas mais duras de reforma da legislação, o legislador deveria poder contar com análises capazes de demonstrar em que medida essas alterações poderiam, de fato, resolver o problema social, evitando-se, assim, que novas leis colaborem para a inflação do ordenamento, e ainda, o que é pior, não

\footnotetext{
${ }^{421}$ Se o Poder Executivo, por exemplo, identifica na proposta uma oportunidade de regulamentar um projeto de política pública que lhe é prioritário, existe uma possibilidade de repercussão mais efetiva da norma, pois não deixará de dispor de meios necessários para sua implementação.

${ }^{422}$ Isso não significa que seja sempre assim. Muitas vezes, o legislador usa a seu favor a distância entre o processo de elaboração e o de implementação legislativa, escolhendo determinada medida como saída simbólica para o problema, mesmo sabendo que ela não poderá ser executada.

${ }^{423}$ Sobre o tema, ver Laura Frade. O que o Congresso Nacional pensa sobre a criminalidade. Tese de doutorado, Instituto de Ciências Sociais, Universidade de Brasília, 2007. A autora mapeou os projetos de lei em segurança pública e justiça criminal em tramitação na $52^{\mathrm{a}}$ Legislatura do Congresso Nacional (2003/2007), constatando que, das 664 propostas de alterações de dispositivos penais apresentadas, apenas 20 tinham o objetivo de relaxar algum tipo penal (Laura Frade. O que o Congresso Nacional..., p. 76). Ver, ainda, Marcelo da Silveira Campos. Crime e Congresso Nacional: uma análise da política criminal aprovada de 1989 a 2006. São Paulo: IBCCRIM, 2010.
} 
contribuam de forma efetiva para o enfrentamento de questões como a violência e da insegurança.

Daí a importância de realizar investigações prévias e avaliação dos efeitos das leis, que possibilitem verificar o impacto que provocam, caso aprovadas, no âmbito judicial, administrativo, econômico e, principalmente, social.

\section{A avaliação legislativa no Brasil}

No Brasil, é mais comum verificar uma preocupação com os aspectos formais da lei do que propostas de avaliação do seu conteúdo. Não que sejam menos relevantes ${ }^{424}$, entretanto não são suficientes para lidar com a crise do direito acima mencionada.

A importância conferida aos aspectos formais da lei pode ser identificada com o fato de privilegiar-se o direito escrito, reconhecendo-se a lei como fonte primária. De outro lado, a concepção do direito como uma ordem hierárquica também faz com que se deva respeitar determinadas regras: quanto maior a graduação da norma, mais generalidade deve conter, sem abandonar a concisão e a coerência ${ }^{425}$.

Do ponto de vista normativo, o art. 59 da Constituição Federal de 1988 determina que "lei complementar disporá sobre a elaboração, redação, alteração e consolidação das leis", tendo sido aprovada, em 1998, a Lei Complementar nº 95, que trata da forma como os atos normativos devem ser estruturados, redigidos, articulados e consolidados, sem adentrar, portanto, em questões de avaliação e de conteúdo ${ }^{426}$.

Posteriormente, o Decreto $\mathrm{n}^{\mathrm{o}} 4.176$, de 28 de março de 2002, tratou de estabelecer normas e diretrizes para a elaboração, redação, alteração e consolidação de atos

\footnotetext{
424 Ao traçar um histórico sobre o desenvolvimento da legística formal, Jean-Pierre Duprat ressalta a importância da forma para o conteúdo, defendendo que ambos não podem ser dissociados, pois é através da forma que se torna possível respeitar os objetivos de clareza, simplicidade, coesão da lei, que possibilitam sua compreensão por todos (Jean-Pierre Duprat. Genèse et developpement de la légistique. In Roland Drago (dir.). La confection de la loi. Paris: Presses Universitaires de France, 2005, p. 10-11).

${ }^{425}$ Victor Nunes Leal. Problemas de direito público. Rio de Janeiro: Forense, 1960, p. 10-11.

${ }^{426}$ É importante mencionar que o descumprimento das normas da Lei Complementar n 95/1998 não gera invalidade do ato normativo, inclusive o art. 18 dispõe que "eventual inexatidão formal de norma elaborada mediante processo legislativo regular não constitui escusa válida para o seu descumprimento".
} 
normativos (medidas provisórias e decretos) a serem encaminhados ao Presidente da República pelos Ministérios e órgãos da estrutura da Presidência.

É só então, ainda que apenas no âmbito dos atos normativos de autoria do Poder Executivo, que aparece uma preocupação com a necessidade de "justificar e fundamentar a edição do ato normativo, de tal forma que possibilite a sua utilização como defesa prévia em eventual argüição de inconstitucionalidade; explicitar a razão de o ato proposto ser o melhor instrumento normativo para disciplinar a matéria; indicar a existência de prévia dotação orçamentária, quando a proposta demandar despesas; demonstrar, objetivamente, a relevância e a urgência no caso de projeto de medida provisória" (art. 38 do Decreto $n^{\circ} 4.176 / 2002$ ).

Na realidade, o anexo I desse decreto explicita todas as questões que devem ser respondidas antes da adoção de determinado texto legislativo, tais como: qual o objetivo pretendido? Que repercussões têm o problema? Que falhas ou distorções foram identificadas? Qual é o conjunto de destinatários alcançados pelo problema? Quais as alternativas disponíveis? A lei é necessária apenas por período limitado? As regras propostas afetam direitos fundamentais? Os direitos de igualdade foram afetados? Quais órgãos ou instituições devem assumir a responsabilidade pela execução das medidas? Existe uma relação equilibrada entre custos e benefícios?

Apesar de impor a análise desses requisitos, não há previsão de ferramentas institucionais que permitam o levantamento de todos esses dados. O órgão responsável pelo recebimento dessas informações, a Subchefia para Assuntos Jurídicos da Casa Civil, acaba realizando, na verdade, uma análise dos aspectos formais e da legalidade e constitucionalidade dos atos normativos que recebe dos Ministérios ${ }^{427}$.

Do ponto de vista da produção teórica sobre o tema, não há muito escrito. Um dos poucos autores a tratar da técnica legislativa, Victor Nunes Leal, dedica um capítulo de seu livro ${ }^{428}$ à tarefa de fazer leis, dispondo tanto sobre aspectos formais, como a

\footnotetext{
${ }^{427}$ De acordo com os incisos II e IV do art. 16 do Decreto $\mathrm{n}^{\circ} 5.135$, de 7 de julho de 2004, que aprova a estrutura regimental e o quadro demonstrativo dos cargos em comissão e das funções gratificadas da Casa Civil da Presidência da República, e dá outras providências, a Subchefia para Assuntos Jurídicos tem a atribuição de verificar, previamente, a constitucionalidade e legalidade dos atos presidenciais e examinar os fundamentos jurídicos e a forma dos atos propostos ao Presidente da República, estando autorizada a devolver aos órgãos de origem aqueles em desacordo com as normas vigentes.

${ }^{428}$ Problemas de direito público. Rio de Janeiro: Forense, 1960, p. 7-32.
} 
necessidade de clareza, precisão, sistematização e consolidação das leis, quanto sobre a importância do legislador observar a vida real, ter em mira o resultado a atingir e escolher os meios adequados ${ }^{429}$.

Ao mencionar que o legislador deveria reunir diversas qualidades, relacionadas ao conhecimento jurídico, a forma e a pureza da linguagem ${ }^{430}$, Victor Nunes Leal trata de uma realidade muito peculiar, relacionada à concepção de um modelo específico de processo legislativo, oriundo das revoluções liberais, onde a lei, como expressão da vontade geral, só poderia ser elaborada a partir de um processo cuidadoso e repleto de oportunidades para que os parlamentares pudessem participar, refletir e opinar ${ }^{431}$, sem esquecer que esses parlamentares se caracterizavam como um grupo homogêneo, totalmente desvinculado dos anseios populares ${ }^{432}$.

Apesar da forma inédita como o autor se dedicou ao tema, rara entre juristas, sua reflexão não foi capaz de indicar o método para se evitar todas essas dificuldades, a não ser quando menciona que o legislador deveria reunir diversos atributos, sem se preocupar em dizer como isso poderia acontecer. A oportunidade de participação se transforma, portanto, em mera observância de ritos e solenidades.

De fato, era mais fácil pensar na tarefa de elaboração de leis quando os legisladores eram visto como um corpo homogêneo, formado pela elite da sociedade, da qual faziam parte muitos juristas ${ }^{433}$, que deveriam se preocupar apenas em observar

\footnotetext{
${ }^{429}$ Victor Nunes Leal. Problemas de direito público..., p. 19-20. Esse autor, entretanto, entende que a tarefa de redigir leis deve ser atribuída "a juristas que, além de sólida cultura, tenham muito tirocínio na aplicação do direito, quer como advogados, quer como juízes, e que sejam homens de mentalidade receptiva, de alma aberta às transformações do mundo", ainda que para exercê-la possam contar com subsídios técnicos (Victor Nunes Leal. Problemas de direito público..., p. 21-22). O autor não abandona, entretanto, a ideia de que é sempre papel da doutrina e da jurisprudência "juntar as diversas leis num sistema orgânico, ajustando as falhas, preenchendo as lacunas, harmonizando as desinteligências entre disposições diferentes, no propósito de colocar sob a incidência da lei, no lugar adequado, toda a múltipla e variada realidade social" (Victor Nunes Leal. Problemas de direito público..., p. 18).

${ }^{430}$ Victor Nunes Leal. Problemas de direito público..., p. 24-25.

431 Rubens Naman Rizek Jr. O processo de consolidação e organização legislativa. Tese de Doutorado, Faculdade de Direito da Universidade de São Paulo, 2009, p. 19-23. Verifica-se que, nesse modelo, apesar da preocupação em garantir "o direito a intervenções individuais, a divisão do processo em fases distintas, as várias oportunidades de discussão (em comissões, em plenário), as várias oportunidades para apresentação de emendas, as várias formas como essas emendas podem ser apresentadas, as várias votações possíveis, o sistema bicameral, a sistemática do veto" (Rubens Naman Rizek Jr. O processo de consolidação..., p. 24), o processo legislativo acabou se tornando confuso e incompreensível, apropriando-se dessas oportunidades mais sob o aspecto formal, sem a intenção de torná-las espaços de reflexão a partir de dados que instruam as decisões tomadas.

${ }^{432}$ Rubens Naman Rizek Jr. O processo de consolidação..., p. 26-27.

${ }^{433}$ Manoel Gonçalves Ferreira Filho. A democracia possivel. $5^{a}$ ed. São Paulo: Saraiva, 1979, p. 12-13.
} 
requisitos formais para elaborar normas, pois seu mérito era fruto da sua própria consciência e da maneira como enxergavam o problema social.

No Brasil, portanto, é mais comum encontrar críticas à produção desenfreada de leis, sem observância de critérios técnicos, do que propostas concretas para lidar com esse problema, exceto sob o aspecto formal ${ }^{434}$.

Entretanto, algumas tentativas de discutir a avaliação das leis podem ser encontradas no Estado de Minas Gerais, onde já foram realizados o Seminário “A consolidação das leis e o aperfeiçoamento da democracia" ${ }^{435}$, em 2002, e o "Congresso Internacional de Legística: qualidade da lei e desenvolvimento" 436, em 2007, que resultaram na produção de diversos artigos sobre o tema ${ }^{437}$.

Além disso, algumas experiências inovadoras no âmbito do Poder Executivo federal devem ser mencionadas. A Secretaria de Assuntos Legislativos do Ministério da Justiça ${ }^{438}$ lançou, em 2007, o Projeto Pensando o Direito, com o intuito de abrir canais de

\footnotetext{
${ }^{434}$ Nesse âmbito, a Presidência da República editou um manual de redação de atos normativos (Gilmar Ferreira Mendes e Nestor José Forster Júnior. Manual de redação da Presidência da República. $2^{\mathrm{a}}$ ed. rev. e atual. Brasília: Presidência da República, 2002, disponível em https://www.planalto.gov.br/ccivil 03/manual/index.htm, acesso em 11.11.2010). A $1^{\text {a }}$ edição do Manual é de 1991. É a partir desse ano que o governo federal começa a se preocupar formalmente com a técnica legislativa, editando, em 1992, o Decreto nº 468, cuja principal inovação foi a centralização, na Casa Civil, da tarefa de revisão dos atos normativos a serem submetidos ao Presidente da República.

435 http://www.almg.gov.br/index.asp?grupo $=$ servicos\&diretorio=publicacoes\&arquivo=consolidacaoleis, acesso em 23.11.2010.

${ }^{436} \mathrm{http}: / /$ www.almg.gov.br/index.asp?grupo=servicos\&diretorio=publicacoes\&arquivo=legistica, acesso em 23.11.2010.

${ }^{437}$ A consolidação das leis e o aperfeiçoamento da democracia. Belo Horizonte: Assembléia Legislativa do Estado de Minas Gerais, 2003 e Congresso Internacional de Legística: qualidade da lei e desenvolvimento. Belo Horizonte: Assembléia Legislativa do Estado de Minas Gerais, 2009. "Os agentes públicos envolvidos com a atividade legislativa têm-se preocupado cada vez mais em incorporar ao processo de elaboração das leis procedimentos específicos de planejamento, avaliação e estudo que sejam capazes de dar mais consistência e qualidade à legislação, além de reforçar a confiança da população nos legisladores. Esses esforços, que procuram aliar a iniciativa política e a participação popular aos benefícios da pesquisa técnica cuidadosa, convergem, do ponto de vista da sistematização do conhecimento, para um campo do saber que vem crescendo e reivindicando cada vez mais a sua autonomia. Tal campo, em torno do qual se organizou o Congresso que deu origem a esta publicação, é o da chamada Legística" (Congresso Internacional de Legística..., p. 9).

${ }^{438}$ A Secretaria de Assuntos Legislativos do Ministério da Justiça tem a competência, dentre outras previstas, de supervisionar e auxiliar as comissões de juristas e grupos de trabalho constituídos pelo Ministro de Estado; coordenar e supervisionar, em conjunto com a Consultoria Jurídica, a elaboração de decretos, projetos de lei e outros atos de natureza normativa de interesse do Ministério; acompanhar a tramitação de projetos de interesse do Ministério no Congresso Nacional (incisos II, IV e V do art. 20 do Decreto $\mathrm{n}^{\circ}$ 6.061, de 15 de março de 2007, que aprova a estrutura regimental e o quadro demonstrativo dos cargos em comissão e das funções gratificadas do Ministério da Justiça, e dá outras providências).
} 
comunicação entre o que estava sendo discutido no âmbito acadêmico e o que vinha sendo produzido no Parlamento ${ }^{439}$.

Desde o início do projeto, as instituições de pesquisa e ensino envolvidas já realizaram diversas avaliações de leis, propondo mudanças com base em dados da realidade e no comportamento dos juízes e da administração pública ${ }^{440}$.

A relevância dessa iniciativa decorre de duas questões: a oportunidade de aproximar a academia do processo legislativo, criando, assim, uma cultura de análise dos atos normativos antes de seu ingresso no ordenamento, e de que as avaliações feitas pela academia possam, de fato, influenciar a elaboração das normas, ao serem utilizadas diretamente pelos órgãos governamentais.

A construção do marco civil da internet também merece ser citada. A Secretaria de Assuntos Legislativos do Ministério da Justiça, em parceria com a Escola de Direito do Rio de Janeiro da Fundação Getúlio Vargas, criou um espaço virtual de construção colaborativo de um marco civil da internet no Brasil ${ }^{441}$, com o intuito de elaborar, em primeiro lugar, uma legislação sobre os direitos e responsabilidades relacionadas com a utilização dos meios digitais, ao invés de uma regulamentação penal sobre o tema ${ }^{442}$.

Mais recentemente, o Ministério da Justiça recorreu a esse tipo de iniciativa para discutir outros temas, como a proteção de dados pessoais, com o intuito de "incentivar

439 As pesquisas realizadas estão disponíveis http://portal.mj.gov.br/conportos/main.asp?View $=\{329 D 6 E B 2-8 A B 0-4606-B 054-4 C A D 3 C 53 E E 73\}$, acesso em 23.11.2010.

${ }^{440}$ Alguns casos podem ser citados. A pesquisa "Os novos procedimentos penais", por exemplo, realizou um diagnóstico quantitativo e qualitativo dos efeitos das Leis $n^{\circ} 11.719 / 2008$ e 11.689/2008, que alteraram dispositivos do Código de Processo Penal relativos ao procedimento, com o intuito de verificar se as mudanças estavam sendo aplicadas na prática, em que medida as modificações surtiram os efeitos esperados e, caso tenha havido um incremento da eficiência (em termos de menor número de dias para o processamento do delito), se isso ocorreu em detrimento das garantias fundamentais do acusado.

${ }^{441}$ O projeto foi lançado em 29 de outubro de 2009. Ver http://culturadigital.br/marcocivil/, acesso em 23.11.2010. Essa parceria surgiu das críticas elaboradas por estudiosos do tema ao Projeto de Lei $\mathrm{n}^{\circ}$ 84/1999, conhecido como Projeto Azeredo, considerado abusivo ao criminalizar condutas praticadas na rede em razão das obrigações de vigilância que impõe e por abranger condutas que não deveriam receber tratamento penal (ver

http://virtualbib.fgv.br/dspace/bitstream/handle/10438/7719/coment $\% \mathrm{C} 3 \% \mathrm{~A} 1$ rios $\% 20 \mathrm{ao} \% 20$ substitutivo $\% 20$ PL\%2088-99.pdf? sequence=1, acesso em 23.11.2010)

442 "A proposta de construção do marco regulatório busca inovar também no processo de sua formulação: o intuito é incentivar, através da própria internet, a participação ativa e direita dos inúmeros atores sociais envolvidos no tema (usuários, academia, representantes da iniciativa privada, além de parlamentares e de representantes do governo)" (http://culturadigital.br/marcocivil/sobre/, acesso em 23.11.2010). 
a colocação de argumentos que possam servir de subsídios para a conclusão da elaboração do projeto lei" proposto pelo Departamento de Proteção ao Consumidor ${ }^{443}$, e a classificação indicativa de programas de televisão, cinema, vídeos e DVDs e jogos eletrônicos, relacionada à atividade regulamentadora da Secretaria Nacional de Justiça ${ }^{444}$.

O espaço virtual começou a ser utilizado, ainda que de forma muito incipiente, não apenas como um local de discussões sobre formulação legislativa, mas também de formulação de políticas públicas, a partir da democratização de conhecimento e informação propiciada pela Internet. Diante da preocupação de ampliar a comunicação com as redes sociais, o Ministério da Cultura desenvolveu um fórum de cultura digital brasileira ${ }^{445}$.

É importante mencionar, ainda, que o governo federal incorporou as discussões realizadas no âmbito da OCDE, já mencionadas nesse capítulo, com foco no sistema regulatório, adotando, inclusive, um instrumento de Análise do Impacto Regulatório, que se aplica, entretanto, apenas às ações das agências regulatórias, e não à proposições legislativas em geral $^{446}$.

De outro lado, o Congresso Nacional tem investido na formação de um quadro de servidores especializados em redação e análise de projetos de lei, que trabalham nas consultorias legislativas ${ }^{447}$, além de destinar recursos ao aprimoramento da tecnologia da informação ${ }^{448}$. Entretanto, a preocupação ainda é maior com relação à forma dos atos normativos ${ }^{449}$ do que com a previsão de mecanismos institucionais que possibilitem a realização de avaliações dos projetos de lei que tramitam no Poder Legislativo.

\footnotetext{
${ }^{443} \mathrm{http}$ ://culturadigital.br/dadospessoais/, acesso em 19.12.2010.

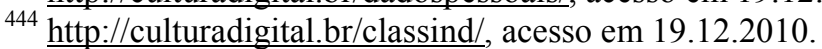

445 Ver http://culturadigital.br, acesso em 19.12.2010. É importante mencionar que no âmbito desse Ministério também foi realizada uma consulta pública sobre o texto de projeto de lei que regulamenta os direitos autorais (http://www.cultura.gov.br/consultadireitoautoral/, acesso em 19.12.2010).

${ }^{446}$ Ver http://www.regulacao.gov.br/, acesso em 19.12.2010.

${ }^{447}$ Apesar de ser grande o número de parlamentares que procuram as consultorias para obter uma opinião técnica sobre os projetos de lei de seu interesse, os pareceres não são vinculativos.

${ }^{448}$ Ver, por exemplo, o Projeto Lex ML (http://projeto.lexml.gov.br/, acesso em 23.11.2010) e o Interlegis Comunidade virtual do Poder Legislativo (http://www.interlegis.gov.br/, acesso em 23.11.2010).

${ }^{449}$ A Consultoria Legislativa do Senado Federal, por exemplo, possui dois manuais sobre a tarefa de redigir atos normativos, o Manual de redação de elaboração de textos, de 1999 (http:/www.senado.gov.br/senado/conleg/manualdeelaboracaodetextos.pdf, acesso em 23.11.2010) e o Manual de técnica legislativa, de 2002 (http://www.senado.gov.br/senado/conleg/tecnicalegislativa-2002.pdf, acesso em 23.11.2010).
} 
A Consultoria Legislativa do Senado Federal, por exemplo, conta com 174 consultores ${ }^{450}$, encarregados de assessorar a mesa, as comissões e os senadores no exercício de suas funções legislativa, parlamentar e fiscalizadora, produzindo minutas de pareceres, de proposições legislativas e de pronunciamentos, além de estudos e notas técnicas de esclarecimento sobre questões relevantes para o Congresso ${ }^{451}$.

Apesar de existir desde 1955, não há nenhuma estrutura, dentro dessa consultoria, de avaliação e monitoramento de projetos de lei, apenas a previsão de realização de estudos técnicos ${ }^{452}$.

Da mesma forma, na Câmara dos Deputados, a consultoria legislativa também tem a função de assessorar os deputados em todas as fases do processo legislativo, elaborando minutas de projetos de lei, estudos técnicos e pronunciamentos ${ }^{453}$, sem a preocupação com uma estrutura de avaliação.

Como vem ocorrendo no Poder Executivo, a Câmara dos Deputados também tem investido na ampliação do caráter democrático do processo de elaboração de leis, criando, com esse objetivo, um portal de interação com a sociedade, o "e-democracia" 454.

De forma não virtual, a Comissão de Legislação Participativa também é um espaço onde as associações e órgãos de classe, sindicatos e entidades organizadas da sociedade civil, podem apresentar sugestões de iniciativa legislativa, que, se aprovadas, são apresentadas como projetos de lei de iniciativa parlamentar ${ }^{455}$.

Além disso, a iniciativa popular, prevista no art. 14, III, da Constituição Federal, permite que, no mínimo, um por cento do eleitorado nacional, distribuído por

\footnotetext{
${ }^{450} \mathrm{http} / / / \mathrm{www}$. senado.gov.br/senado/conleg/insti_consultores.htm, acesso em 23.11.2010.

451 http://www.senado.gov.br/senado/conleg/institucional.htm, acesso em 23.11.2010.

${ }^{452}$ De acordo com o último relatório disponível na página da Consultoria Legislativa do Senado Federal, de 2007, os consultores se dividem por área temática em quatro núcleos, direito, economia, pronunciamentos e social, cada um deles coordenado por um consultor-geral adjunto. Além disso, a consultoria conta com um serviço de apoio técnico, um serviço de apoio administrativo e um gabinete. De acordo com o relatório, no segundo semestre de 2007 foi criada a coordenação de estudos, com o objetivo de desenvolver análises técnicas acerca dos temas de interesse do Senado Federal, que são debatidos em seminários com a presença de especialistas nos assuntos tratados (http://www.senado.gov.br/senado/conleg/artigos/Rel 2007.pdf, acesso em 23.11.2010). Percebe-se que não se trata de avaliar os projetos de leis no sentido utilizado nesse capítulo, mas de produzir um relatório técnico sobre o tema.

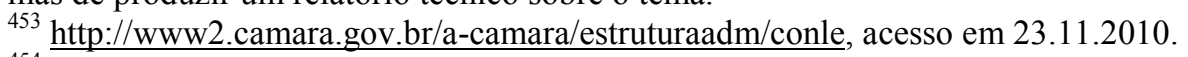

454 http://www.edemocracia.camara.gov.br/publico/, acesso em 19.12.2010.

455 Art. 32, XII, do Regimento interno da Câmara dos Deputados (Resolução ${ }^{\circ}$ 17, de 1989). No Senado Federal, de acordo com art. 102-E do Regimento Interno (Resolução ${ }^{\circ}$ 93, de 1970) essa iniciativa é possível perante a Comissão de Direitos Humanos e Legislação Participativa.
} 
cinco Estados, com não menos de três décimos por cento dos eleitores de cada um deles, apresente à Câmara dos Deputados projeto de lei (art. 61, §2 , da Constituição Federal).

Entretanto, diante de critérios tão exigentes, raramente esse mecanismo é utilizado, sendo que na maioria das vezes, a mobilização pública faz com que algum deputado adote a iniciativa. É o que ocorreu com a Lei $n^{\circ}$. 8.930/1994, que aumentou o rol dos crimes hediondos e contou com a mobilização da autora de novelas Gloria Perez.

Da mesma forma, as comissões de legislação participativa do Congresso Nacional apresentam limitações, pois não permitem a apresentação individual de sugestões.

Todas essas iniciativas, entretanto, estão mais voltadas a um processo de democratização da informação e conhecimento do processo legislativo, assim como buscam assegurar a participação crescente dos indivíduos na elaboração de normas, do que com a avaliação das leis.

Inclusive, não há no âmbito do Poder Legislativo mecanismo semelhante ao que existe no Poder Executivo, previsto no Decreto $n^{\circ} 4.176 / 2002$, que impõe a resposta a uma série de quesitos na apresentação de um projeto de lei.

No Poder Legislativo, deputados e senadores devem apenas, ao apresentar uma proposição de sua autoria, acompanhá-las de justificação oral ou escrita, ${ }^{456}$ sem que haja indicação, no regimento interno das respectivas casas do Congresso Nacional, de como deve ser essa fundamentação, que se resume, na maioria das vezes, a uma explicação sucinta sobre o que impulsionou o legislador a apresentar o projeto de lei.

Por fim, é importante dizer que tanto o Poder Executivo quanto o Poder Legislativo costumam criar grupos de trabalho para discutir temas de maior relevância e que tratem de questões técnicas com especialistas da área ${ }^{457}$, mas a representatividade

\footnotetext{
456 Art. 238 do regimento interno do Senado Federal e art. 103 do regimento interno da Câmara dos Deputados.

${ }^{457}$ É o caso dos projetos de lei já mencionados, que modificaram o Código de Processo Penal e foram elaborados por uma comissão, formada no âmbito do Poder Executivo em 2001 e composta pelos juristas Ada Pellegrini Grinover, Antônio Magalhães Gomes Filho, Antônio Scarance Fernandes, Luiz Flávio Gomes, Miguel Reale Júnior, Nilzardo Carneiro Leão, René Ariel Dotti, Rogério Lauria Tucci, Sidnei Beneti e Petrônio Calmon Filho. Da mesma forma, tramita no Senado Federal um projeto de lei (n $\left.n^{o} 156 / 2009\right)$ que reforma o Código de Processo Penal e foi elaborado por uma comissão de juristas formada por Antonio Correa, Antonio Magalhães Gomes Filho, Eugênio Pacelli de Oliveira, Fabiano Augusto Martins Silveira,
} 
desses grupos é muito pequena, uma vez que não um critério predeterminado de escolha dos seus membros.

Da mesma forma, tanto a Câmara dos Deputados, quanto o Senado Federal, costumam realizar audiências públicas para discutir projetos de lei que tratam de questões técnicas, mas também não um critério de representatividade na escolha dos convidados, nem obrigação de vinculação, ou de justificação da opção por não utilizá-los, aos dados por eles apresentados.

Nota-se que, no Brasil, apesar de algumas iniciativas interessantes sobre a participação no processo legislativo e a possibilidade de análise crítica das propostas apresentadas, não há mecanismos institucionais de avaliação da legislação, sendo esse tema discutido ainda de forma muito incipiente.

\section{Avaliação no processo legislativo penal}

Uma breve análise dos projetos de lei em tramitação no Congresso Nacional na área penal é suficiente para demonstrar o tipo de justificativa que impulsiona o legislador a apresentar proposições sobre o tema.

Na pesquisa realizada pela Escola de Direito da Fundação Getúlio Vargas de São Paulo, com o intuito de identificar os argumentos mais recorrentes nos discursos dos legisladores, fica evidente a ausência de preocupação com a fundamentação dos projetos de lei apresentados ${ }^{458}$.

A partir de alguns indicadores, a pesquisa constatou que a justificação dos projetos de lei, na maioria dos casos, não faz menção a episódios concretos, dados

Felix Valois Coelho Júnior, Hamilton Carvalhido, Jacinto Nelson de Miranda Coutinho, Sandro Torres Avelar e Tito Souza do Amaral.

${ }^{458}$ A pesquisa abrangeu uma amostra de cem projetos de lei contendo normas penais selecionada entre o período de 1986 a 2006. Com relação às justificativas dos projetos de lei, foram utilizados dois indicadores, um dedicado ao tamanho do texto e outro a valoração de sua densidade e consistência (forte, médio e fraco). Quanto ao primeiro indicador, a maioria dos projetos de lei tinha até meia página (38) ou entre meia e uma página (31) e no que se refere ao segundo indicador, a maioria foi considerada com densidade e consistência fraca (54), sendo que no cruzamento desses dados verifica-se que é difícil sustentar argumentos e objetivos de forma sucinta e, concomitantemente, consistente e elaborada (Maíra Rocha Machado et alli. Atividade legislativa..., p. 30-31). 
empíricos, decisões judiciais ou questões do cenário internacional ${ }^{459}$, não havendo muito esforço do legislador em oferecer razões consistentes para defender suas propostas.

A análise das propostas de emenda a Constituição, por exemplo, demonstrou que, com relação a alguns critérios como coerência argumentativa, apresentação de dados que fundamentem afirmações, ausência de argumentos meramente retóricos, bem como explicação detalhada de como a proposta poderia resolver um determinado problema a ser enfrentado, nenhuma foi considerada de teor forte ${ }^{460}$.

Além disso, é frequente a realização de associações equivocadas porque não encontram nenhuma referência concreta que as sustentem. É o caso de projetos de lei que propõem o aumento da pena ou a criação de novos tipos penais com o intuito de diminuir a criminalidade ou combater algum fato violento sem demonstração da relação necessária entre o problema e a solução apresentada, nem identificação dos instrumentos necessários para resolver a questão.

Diversas justificativas, inclusive, são utilizadas de acordo com a conveniência do legislador. As conclusões da pesquisa mencionada demonstram que alguns conceitos são empregados sem nenhum conteúdo ou significação específica ${ }^{461}$, mas, em geral, favorecem a criminalização e o agravamento do tratamento penal.

É o caso do conceito de bem jurídico, que, apesar de ser utilizado pela doutrina como um forte argumento contra a criminalização de condutas, no sentido de distinguir as condutas que devem e as que não devem ser objeto de tutela penal ${ }^{462}$, tem servido para justificar a ampliação da esfera de atuação penal ${ }^{463}$.

A ausência de avaliação fica mais evidente quando se trata de questões penais porque, nesse caso, fica mais fácil se esquivar da necessidade de justificar as razões de determinada proposta, recorrendo-se ao medo e a sensação de insegurança da população.

\footnotetext{
${ }^{459}$ Maíra Rocha Machado et alli. Atividade legislativa..., p. 32.

460 Maíra Rocha Machado et alli. Atividade legislativa..., p. 44. Do total das propostas de emenda à Constituição em tramitação no período de 1988 a 2006, 23 foram selecionadas como amostra.

${ }^{461}$ Esses conceitos são denominados de "envelopes vazios" pelos pesquisadores. (Maíra Rocha Machado et alli. Atividade legislativa..., p. 88).

${ }^{462}$ Maíra Rocha Machado et alli. Atividade legislativa..., p. 89.

${ }^{463}$ Maíra Rocha Machado et alli. Atividade legislativa..., p. 96.
} 
Nesse sentido, basta afirmar que é preciso enfrentar a violência causada por determinado acontecimento, sem demonstrar-se como a medida apresentada poderia, de fato, contribuir para esse objetivo, justificando-se, assim, a proposição apresentada.

Ocorre que se trata de uma das áreas onde a avaliação adquire mais importância, em razão de sua associação a medidas de intervenção do Estado na esfera da liberdade e da integridade física individuais.

Se o legislador propõe a criação um novo tipo penal mediante a imposição de pena de prisão, precisa ter consciência de que as consequências dessa medida atingem um dos bens mais valiosos, a liberdade.

Assim, mais do que saber se o Estado está preparado para lidar com o aumento da demanda de investigação e processamento desses novos casos, e de vagas no sistema penitenciário, o legislador deve refletir sobre as restrições que passa a impor aos cidadãos com a nova medida, que só deverá ser aplicada se de fato puder resolver o problema, a um custo justificável.

O processo legislativo nessa área deve ser pensado, portanto, como um instrumento de política criminal, impondo restrições que se justifiquem mediante a apresentação de dados concretos e a realização de avaliações de impacto.

De certa forma, o enfoque na identificação do problema, da finalidade e nos efeitos perseguidos é capaz de assegurar que sejam observados, na tarefa de formulação do direito penal, os limites impostos pelo seu emprego como última instância de interferência na sociedade. 


\section{CONSIDERAÇÕES FINAIS}

O distanciamento entre o direito e a política é fruto da forma como essas ciências se relacionaram ao longo do seu desenvolvimento. Enquanto a ciência política buscava afirmar sua autonomia, renegando aos juristas o estudo da norma, alheio à realidade, o direito adota uma postura de isolamento e, até, de superioridade, que ficou mais evidente com o advento do positivismo jurídico, consubstanciada no culto à lei posta.

Para o direito, a consequência dessa relação é a limitação que provoca em sua investigação, privando-o dos instrumentos metodológicos comuns a outras ciências e transformando seu estudo em uma análise voltada para a norma após o seu ingresso no ordenamento, exageradamente legalista e formalista.

A ciência do direito, portanto, acabou se restringido à dogmática jurídica. No âmbito específico do processo legislativo, o resultado é a falta de preocupação com esse tema, exceto sob o aspecto de sua regulamentação formal.

Nesse sentido, a análise do direito ficou limitada aos seus aspectos internos e se desenvolveu independentemente de questões importantes que circundam o processo legislativo, como, por exemplo, a maneira como se dá a formação da lei.

Essa delimitação fica mais evidente quando se compreende o papel de alguns dogmas que sustentam o direito moderno, como a racionalidade e a soberania do legislador.

O primeiro assegura a abstração de que o legislador pode ser motivado por interesses circunstanciais e influenciado pelos interesses que movimentam o processo legislativo, garantindo, assim, a presunção de que as normas produzidas são precisas, coerentes, consistentes e se encontram adequadas ao ordenamento jurídico vigente, além da presunção de que o legislador tem conhecimento suficiente para escolher o meio mais adequado para atingir determinados fins. 
O segundo confere ao conjunto de normas jurídicas um critério de pertencimento a um sistema próprio, remetendo-as a uma mesma fonte, a um critério único de validação e a uma autoridade comum, consubstanciadas no Estado, capaz de expressar a vontade geral da população.

A compreensão da diferença entre dogmática e ciência do direito, superando-se a hipertrofia da primeira em relação à segunda, permite que o jurista possa compreender seu objeto como um observador externo, desvinculado dos dogmas que sustentam determinada forma de pensar o direito.

Esse parece ser o caminho para compreender o processo de elaboração normativa como um lugar de atuação do jurista e da apresentação de propostas que contribuam para a modificação do ordenamento jurídico.

Em linhas gerais, é possível afirmar que o presente trabalho consiste em uma proposta de superação de alguns dogmas que sustentam o direito pensado como um modelo fechado e hierárquico de normas.

De um lado, é preciso abandonar o aspecto transcendental do direito, a partir da sua compreensão como resultado de um processo complexo, historicamente situado e limitado, onde participam diversos atores e do qual decorrem negociações e compromissos que sofrem a influência de interesses específicos.

O direito não deve ser concebido, portanto, como resultado da atuação de um legislador presumidamente racional, mas de um processo onde circulam informações e dados técnicos, permeado pelos instrumentos de participação e avaliação típicos das tarefas de elaboração e execução de políticas públicas.

Diante da diversidade e complexidade dos temas a serem regulamentados, é importante trazer informação ao processo legislativo, auxiliando, assim, a tomada de decisão política, mediante a ajuda de especialistas, a coleta de dados e o desenvolvimento de tecnologia de informação e participação e de mecanismos de avaliação.

Nesse sentido, as normas jurídicas deixam de ser elaboradas sem qualquer consideração à realidade, mediante a imposição de um modelo pré-concebido, assumindo uma função instrumental, como mecanismo capaz de produzir determinados efeitos sociais. 
De outro lado, diante das transformações que tornam a sociedade cada vez mais complexa e acelerada, o direito se vê ameaçado, perdendo, no limite, a capacidade de solucionar os conflitos sociais.

Uma das formas de lidar com esse conflito é submeter o direito a métodos de elaboração e de avaliação rigorosos, que funcionem como um filtro de contenção às normas editadas de maneira casuística e anárquica.

Além disso, como forma de superar as dificuldades oriundas da concepção da lei enquanto expressão da vontade geral, é preciso aproximar o direito da política, identificando o processo legislativo como expressão da conjunção de esforços coletivos, do qual todos os interessados têm a oportunidade de participar.

Essa mudança de concepção passa pela reformulação do conceito de democracia representativa, na medida em que o povo deixa de ser identificado como uma massa homogênea para ser compreendido como um conjunto de histórias singulares, de situações específicas.

Assim, a condição para aprovação de uma lei é o legislador não deixar apenas seus interesses dominarem, satisfazendo todos os interesses na medida do possível. Uma das formas de fazer isso é dar oportunidade para todos se manifestarem, desde que o façam de forma crítica, apoiando-se em argumentos que podem ser contestados publicamente por contra-argumentos, num processo contínuo de discussão.

Mais do que a superação de alguns dogmas que sustentam o direito, trata-se da ampliação do conceito de democracia e da restauração do papel do Poder Legislativo como um lugar de resolução de questões importantes para a sociedade, sem que os direitos fundamentais e as liberdades públicas sejam renegados.

No âmbito específico do direito penal, a tarefa de influenciar a atividade de elaboração normativa foi assumida, do ponto de vista teórico, pela política criminal.

Entretanto, conforme analisado, reproduz-se entre direito penal e política criminal a mesma dificuldade quanto ao papel que cada uma delas desempenha com relação ao seu objeto de estudo. 
Ao atribuir à política criminal a função de analisar a realidade e apresentar as orientações políticas, sociológicas e éticas que devem orientar a formulação de leis em matéria penal, o direito impõe, como limite a essa atuação, a dogmática, na medida em que a estratégia formulada a partir daí não pode ultrapassar os princípios estruturais do próprio direito penal.

A política criminal, de outro lado, em busca de sua autonomia, proclama sua independência em relação a essa função, ampliando seu escopo de análise. Uma consequência dessa postura é o afastamento da sua tarefa de orientar o processo legislativo.

Percebe-se, portanto, que ao considerar apenas como as finalidades políticocriminais perpassam os institutos penais, ou seja, como essas finalidades são traduzidas em normas jurídicas, o direito ignora sua relação com a política criminal, deixando de lado um conjunto de informações complexas, que poderia auxiliá-lo na tarefa de elaboração de leis.

Conforme observado, o processo legislativo em matéria penal deve ser impulsionado por instrumentos de política criminal, isto é, a formulação de um ato normativo deve ocorrer mediante a realização de um diagnóstico preciso da realidade, determinando-se os objetivos que se pretende alcançar e os possíveis efeitos da intervenção.

Além disso, a ampliação da participação na formulação de leis penais não deve encontrar resistências em razão da necessidade de proteção de direitos fundamentais, como a liberdade, preconizando-se que apenas especialistas poderiam discutir essa matéria como forma de afastar medidas populistas, elaboradas como resposta aos anseios punitivos da sociedade.

É importante que a dogmática jurídica, por exemplo, não adote uma postura de repúdio, afastando qualquer possibilidade de diálogo com os defensores dessas medidas, como caminho, inclusive, de inovação da sua própria teoria, mas, mais do que isso, como postura de abertura à discussão democrática das leis.

Ao agir dessa forma, não consegue impedir que leis desse tipo sejam formuladas, fechando-se à oportunidade de apresentar seus argumentos, podendo, inclusive, convencer aqueles que pensam de maneira diferente. 
Conforme analisado, uma das formas de ampliar a produção de argumentos é fornecer o maior número de informações possíveis ao debate, que sejam capazes de sustentar a apresentação de proposições legislativas sobre direito penal.

Essas informações devem ser fornecidas mediante a busca de dados concretos sobre o tema que se quer regulamentar e a adoção de políticas de avaliação legislativa e de análise de impacto das leis, ainda incipientes no Brasil.

Conforme analisado no terceiro capítulo, apesar de diversos países demonstrarem preocupação com a verificação dos efeitos concretos e o grau de aplicação das leis, inclusive, diante de um aumento crescente de sua quantidade, que, no limite, compromete sua eficiência, no Brasil é mais comum verificar a preocupação com os aspectos formais das leis.

Apesar de algumas iniciativas interessantes que ampliam a participação dos interessados no processo de formulação legislativa, especialmente no Poder Executivo, não se verifica, no Brasil, a institucionalização de mecanismos de avaliação da legislação.

A proposta de avaliação da legislação consiste, na realidade, em uma forma de influenciar o processo de tomada de decisão política, contribuindo com dados concretos para a escolha do legislador, que deve ser justificada e submetida à discussão entre todos os interessados.

A adoção de medidas de avaliação e análise do impacto das leis se insere, portanto, em uma concepção mais ampla, de formulação do direito como política pública, de forma que a participação dos interessados seja mediada por dados e objetivos precisos, com o intuito de assegurar que a sua tarefa de responder às demandas sociais seja realizada de forma efetiva e, no limite, fortalecer a democracia. 


\section{BIBLIOGRAFIA}

ABRAMOVAY, Pedro Vieira. A separação de Poderes e as medidas provisórias em um Estado Democrático de Direito. Dissertação de Mestrado, Faculdade de Direito da Universidade de Brasília, 2010.

ALEXY, Robert. Constitucionalismo discursivo. Tradução Luís Afonso Heck. Porto Alegre: Livraria do Advogado, 2007.

ALMEIDA, Marta Tavares de. Avaliação da legislação em Portugal. Legislação: Cadernos de Ciência da Legislação, n. 33/34, jan.-jun. 2003, p. 93-106.

ALMEIDA, Marta Tavares de Almeida. A contribuição da Legística para uma política de legislação: concepções, métodos e técnicas, p. 8. Congresso Internacional de Legística qualidade da lei de desenvolvimento, Belo Horizonte-MG, disponível em http://www.almg.gov.br/eventos/Legistica/imagens/Marta Tavares.pdf, acesso em 06.11.2010.

AMSELEK, Paul. L'evolution generale de la technique juridique dans les sociétés occidentales. In MORAND, Charles-Albert (org.). L'Etat propulsif. Paris: Publisud, 1991, p. $129-154$.

ANCEL, Marc. Por une étude systematique des problèmes de politique criminelle. Archives de Politique Criminelle, n. 1, 1975, p. 15-42.

ARON, Raymond. Démocratie et totalitarisme. Paris: Gallimard, 1965.

ASSIS, Luiz Gustavo Bambini de. Processo legislativo e orçamento público : a função de controle do parlamento. Tese de Doutorado, Faculdade de Direito da Universidade de São Paulo, 2009.

ATIAS, Christian. Science des légistes, savoir des juristes. Aix-Marselle: Presses Universitaires d'Aix-Marselle, 1991.

ATIENZA, Manuel. Argumentación y legislación. In DIÉZ RIPOLLÉS, José Luis; PRIETO DEL PINO, Ana María; SOTO NAVARRO, Susana (ed.). La política legislativa penal en occidente. Una perspectiva comparada. Valencia: Tirant lo blanch, 2005, p. 1945 .

BACIGALUPO, Enrique. Significación y perspectivas de la oposición "derecho penal política criminal”. Revue Internationale de Droit Pénal, n. 1, 1978, p. 15-28.

BANKOWSKI, Zenon et al. La science de la legislation. Paris: PUF, 1988.

BATIFFOL, Henri. Problèmes de frontières: droit et politique. Archives de philosophie du droit, n. 16, 1971, p. 1-14.

BATISTA, Nilo. Introdução crítica ao direito penal brasileiro. $11^{\text {a }}$ ed. Rio de Janeiro: Revan, 2007. 
BENDIX, Reinhard. Max Weber. Um perfil intelectual. Trad. Elisabeth Hanna e José Viegas Filho. Brasília: UNB, 1986.

BERGEL, Jean-Louis. Appréciation méthodologique sur l'évaluation législative. Revue de la recherche juridique, n. 4, 1994, p. 1167-1174.

BERNARDI, Alessandro. Experiénces italiennes recentes en matiére de science et de technique de la législation pénale. Archives de Politique Criminelle, n. 9, 1987, p. 171-189.

BERNAT de CELIS, Jacqueline. La politique criminelle a la recherche d'elle-meme. Archives de Politique Criminelle, n. 2, 1977, p. 3-60.

BISSON, Alain-François. L'interaction des techniques de rédaction et des techniques d'interprétation des lois. Les cahiers du droit, v. 21, n. 3 e 4, 1980, p. 511-522.

BLANKENBURG, Erhard. La recherche de l'efficacité de loi. Réflexions sur l'étude de la mise en œuvre (le concept « d'implementation »). Droit et société, 2, 1986, p. 73-94.

BOBBIO, Norberto. O positivismo jurídico. Lições de filosofia do direito. Trad. Márcio Pugliesi, Edson Bini e Carlos Rodrigues. São Paulo: Ícone, 1995.

BOBBIO, Norberto; MATTEUCCI, Nicola e PASQUINO, Gianfranco. Dicionário de

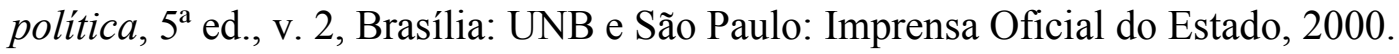

BORJA JIMÉNEZ, Emiliano. Curso de política criminal. Valencia: Tirant lo blanch, 2003.

BOTTINI, Pierpaolo Cruz. Crimes de perigo abstrato e princípio da precaução na sociedade de risco. São Paulo: Revista dos Tribunais, 2007.

BOTTINI, Pierpaolo Cruz. O princípio da proporcionalidade na produção legislativa brasileira e seu controle judicial. Revista Brasileira de Ciências Criminais, ano 18, n. 85, jul.-ago. 2010, p. 267-296.

BOURDIEU, Pierre. La force du droit. Actes de la recherche en sciences sociales, v. 64, $\mathrm{n}$. 1, 1986, p. 3-19.

BOURDIEU, Pierre. Razões práticas sobre a teoria da ação. $8^{\mathrm{a}}$ ed. Trad. Mariza Corrêa. Campinas: Papirus, 2007.

BOURJOL, Maurice; DUJARDIN, Philippe; GLEIZAL, Jean-Jacques; JEAMMAUD, Antonie; JEANTIN, Michel; MIAILLE, Michel; MICHEL, Jacques. Por une critique du droit. Du juridique au politique. Grenoble: Presses Universitaires de Grenoble, 1978.

BUCCI, Maria Paula Dallari. Direito administrativo e políticas públicas. São Paulo: Saraiva, 2006.

CAILLOSSE, Jacques. Droit et politique: vieilles lunes, nouveaux champs. Droit et Société, 26, 1994, p. 127-155. 
CAMARGO, Antonio Luís Chaves. Sistema de penas, dogmática jurídica e política criminal. São Paulo: Cultura Paulista, 2002.

CAMPILONGO, Celso Fernandes. Representação política. São Paulo: Ática, 1988.

CAMPOS, Marcelo da Silveira. Crime e Congresso Nacional: uma análise da política criminal aprovada de 1989 a 2006. São Paulo: IBCCRIM, 2010.

CARBONNIER, Jean. Droit Civil. Introduction. 27ª ed. Paris: PUF, 2002.

CARBONNIER, Jean. Essais sur les lois. $2^{\mathrm{a}}$ ed. Paris: Répertoire du notariat Defrénois, 1995.

CARBONNIER, Jean. Sociologique juridique. Paris: Quadrige/PUF, 2004.

CARRARA, Francesco. Lineamenti di pratica legislativa penale. Bologna: Mulino, 2007.

CARVALHO NETTO, Menelick de. A sanção no procedimento legislativo. Belo Horizonte: Del Rey, 1992.

CARVALHO NETTO, Menelick de. Racionalização do ordenamento jurídico e democracia. In A Consolidação das leis e o aperfeiçoamento da democracia. Belo Horizonte: Assembléia Legislativa do Estado de Minas Gerais, 2003, p. 13-38.

CARVALHO NETTO, Menelick de. Apresentação. In ROSENFELD, Michel. $A$ identidade do sujeito constitucional. Belo Horizonte: Mandamentos, 2003.

CHEVALLIER, Jacques. Doctrine juridique et science juridique. Droit et Société, 50, 2002, p. 103-119.

CHEVALLIER, Jacques. La juridicisation des precepts manageriaux. Politiques et management public, v. 11, n. 4, dec. 1993, p. 111- 134.

CHEVALLIER, Jacques. La régulation juridique en question. Droit et Société, 49, 2001, p. 827-846.

CHEVALLIER, Jacques. La rationalisation de la production juridique. In MORAND, Charles-Albert (org.). L'Etat propulsif. Paris: Publisud, 1991, p. 11-48.

CHEVALLIER, Jacques. Les doctrines de l'État de droit. Le droit dans la societé. Cahiers français, 288, oct. - dez. 1998, p. 3-8.

CHEVALLIER, Jacques. L'État de droit. 5ª ed. Paris: Montchrestien, 2010.

CHEVALLIER, Jacques. L'État post-moderne. Collection Droit et Société, n. 35. Paris: L.G.D.J., 2008.

CHEVALLIER, Jacques. Rapport introductif. Revue de la recherche juridique, n. 4, 1994, p. 1081-1096. 
CHEVALLIER, Jacques. Science du droit et science du politique d l'opposition a la complementarite. In Droit et Politique. Paris: PUF, 1993, p. 252-268.

CHEVALLIER, Jacques. Vers um droit post-moderne? Les transformations de la régulation juridique. Revue de droit public et de la science politique, n. 3, 1998, p. 659690.

COMMAILLE, Jacques; DUMOULIN, Laurence; ROBERT, Cécile. La juridicisation du politique. Paris: L.G.D.J., 2010.

COMMAILLE, Jacques. L'esprit sociologique des lois. Essai de sociologie politique du droit. Paris: PUF, 1994.

COMMAILLE, Jacques e LASCOUMES, Pierre. La production gouvernementale du droit. France, Mission de Recherche Droit et Justice, 1995.

CORREAS, Óscar. Kelsen y Gramsci o de la eficacia como signo de hegemonia. Crítica Jurídica, n. 10, 1992, p. 37-93.

COSTA, José de Faria. A criminalidade em um mundo globalizado: um plaidoyer por um direito penal não-securitário. In COSTA, José de Faria e SILVA, Marco Antonio Marques da (coord.). Direito penal especial, processo penal e direitos fundamentais - visão lusobrasileira. São Paulo: Quartier Latin, 2006.

CUBERTAFOND, Bernard. La creátion du droit. Paris: Ellipses, 1999.

DABIN, Jean. Techinique de l'élaboration du droit positif. Bruxelles: Établissements Émile Bruylant e Paris: Librarie du Recueil Sirey, 1935.

DAUTRICOURT, J.Y. De la loi penale a la loi de politique criminelle. Archives de politique criminelle, n. 2, 1977, p. 83-103.

DELCAMP, Alain; BERGEL, Jean-Louis e DUPAS, Alain (org.). Contrôle parlementaire et évaluation. Paris: La documentation française, 1995.

DELLEY, Jean-Daniel. Pensar a lei. Introdução a um procedimento metódico. Cadernos da Escola do Legislativo, Belo Horizonte, v. 7, n. 12, jan.-jun. 2004, p. 101-143.

DELMAS-MARTY, Mireille. La politique pénale est-elle une politique publique comme les autres? Revue de Science Criminelle et de Droit Pénal Comparé (1), jan.-mar. 1994, p. 150-154.

DELMAS-MARTY, Mireille. Les grands systèmes de politique criminelle. Paris: Thémis/PUF, 1992.

DELMAS-MARTY, Mireille. Modèles et mouvements de politique criminelle. Paris: Economica, 1983.

DELMAS-MARTY, Mireille. Pour des principes directeurs de législation pénale. Revue de science criminelle et de droit pénal comparé, 1-2, jan.-jun. 1985, p. 225-229. 
DEROUSSIN, David. Politique criminelle et politique pénale. Disponível em http://www.afhj.fr/ressources/deroussin-ppp.PDF, acesso em 23.03.2010

DESSEMONTET, François. Language et système des lois suisses. Les cahiers du droit, v. 21, n. 3 e 4, 1980, p. 579-597.

DÍEZ RIPOLLÉS, José Luis. Politica criminal y derecho penal. Estudios. Valencia: Tirant lo Blanch, 2003.

DIMOULIS, Dimitri. Positivismo Jurídico: introdução a uma teoria do direito e defesa do pragmatismo jurídico-político. São Paulo: Método, 2006.

DRAGO, Roland (dir.). La confection de la loi. Paris: Presses Universitaires de France, 2005.

DURAN, Patrice. Le savant et la politique: pour une approche raisonnée d l'analyse des politiques publiques. L'année sociologique, 40, 1990, p. 227-259.

DURAN, Patrice. Piloter l'action publique, avec ou sans le droit? Politiques et management public, v. 11, n. 4, dec. 1993, p. 1- 45.

DWORKIN, Ronald. Law's empire. Cambridge: Harvard University Press, 1986.

ENGUÉLÉGUÉLÉ, Stéphane. Etat, criminalité organisée et strategie penale: elements pour l'analyse des politiques criminelles en Afrique. Disponível em http://www.polis.sciencespobordeaux.fr/vol3n1/article2.html, acesso em 23.03.2010

ENGUÉLÉGUÉLÉ, Stéphane. Les communautés épistémiques pénales et la production législative en matière criminelle. Droit et Société, 40, 1998, p. 563-581.

ENGUÉLÉGUÉLÉ, Stéphane. Les politiques pénales (1958-1995). Paris : L’Harmattan, 1998.

FARIA, José Eduardo Campos de Oliveira. Direito e justiça no século XXI: a crise da justiça no Brasil. Seminário "Direito e Justiça no século XXI, Coimbra, Centro de Estudos Sociais, 2003, disponível em http://opj.ces.uc.pt/portugues/novidds/comunica/JoseEduarFaria.pdf, $\quad$ acesso em 19.10.2010.

FARIA, José Eduardo Campos de Oliveira. Justiça e conflito (os juizes em face dos novos movimentos sociais). $2^{\text {a }}$ ed. rev. e ampl. São Paulo: Revista dos Tribunais, 1992.

FARIA, José Eduardo Campos de Oliveira. O direito na economia globalizada. $1^{\mathrm{a}}$ ed. $3^{\mathrm{a}}$ tiragem. São Paulo: Malheiros, 2002.

FARIA, José Eduardo Campos de Oliveira. Poder e legitimidade. Uma introdução à política do direito. São Paulo: Perspectiva, 1978. 
FARIA, José Eduardo Campos de Oliveira. Sociologia: Direito e conjuntura. São Paulo: Saraiva, 2010.

FARIA, José Eduardo Campos de Oliveira. Verbete legitimidade. In NOGUEIRA, Marco Aurélio (coord.). Dicionário de Políticas Públicas. São Paulo: Unesp/Fundap, no prelo.

FERRAZ JR., Tércio Sampaio. A ciência do direito. São Paulo: Atlas, 1977.

FERRAZ JR., Tércio Sampaio. Introdução ao estudo do direito. $4^{\mathrm{a}}$ ed. São Paulo: Atlas, 2003.

FERREIRA FILHO, Manoel Gonçalves. Do processo legislativo. São Paulo: Saraiva, 2007.

FERRY, Luc. Tradition ou argumentation? Des comités de «sages » aux comités de déliberation. Pouvoirs, n. 56, 1991, p. 5-21.

FISHER, Louis. Constitucional dialogues: interpretation and political process. New Jersey: Princeton University Press, 1988.

FRADE, Laura. O que o Congresso Nacional pensa sobre a criminalidade. Tese de doutorado, Instituto de Ciências Sociais da Universidade de Brasília, 2007.

FLEURY, Sabino. Judicialização da política e politização da justiça: os partidos políticos e o controle da constitucionalidade das leis no Brasil. Cadernos da Escola do Legislativo, Belo Horizonte, v. 12, n. 18, jan.-jun. 2010, p. 5-46.

FREUND, Julien. Droit et politique. Essai de définition du droit. Archives de philosophie du droit, n. 16, 1971, p. 15-35.

GALMARD, Marie-Hélène. État, société et loi pénale. Aix-en-Provence: Presses Universitaires d'Aix-Marseille, 2006.

GAROUPA, Nuno. Limites ideológicos e morais à avaliação económica da legislação. Legislação: Cadernos de Ciência da Legislação, n. 42/43, jan.-jun. 2006, p. 83-102.

GAROUPA, Nuno e VILAÇA, Guilherme Vasconcelos. A prática e o discurso da avaliação legislativa em Portugal. Legislação: Cadernos de Ciência da Legislação, n. 44, out.-dez. 2006, p. 5-29.

GAROUPA, Nuno. Improving legislation - a note of pessimism. Legislação: Cadernos de Ciência da Legislação, n. 50, out.-dez. 2009, p. 153-160.

GENY, François. Science et technique en droit privé positif, partie III. Paris: Librairie de la Societé du Recueil Sirey, 1921.

GLEIZAL, Jean-Jacques. Le droit politique de l'Etat. Essai sur la production historique du droit administratif. Paris: PUF, 1980. 
GÜNTHER, Klaus. Teoria da responsabilidade no Estado democrático de direito: textos de Klaus Günther. PÜSCHEL, Flavia Portella e MACHADO, Marta Rodriguez de Assis (org.). São Paulo: Saraiva, 2009.

GÜNTHER, Klaus. The sense of appropriateness: application discourses in morality and law. Trad. John Farrell. New York: State University of New York, 1993.

HABER, Carolina Dzimidas. A eficácia da lei penal: análise a partir da legislação penal de emergência (o exemplo do regime disciplinar diferenciado). Tese de mestrado, Faculdade de Direito da Universidade de São Paulo, 2007.

HABERMAS, Jürgen. A inclusão do outro. Estudos de teoria política. Trad. George Sperber, Paulo Astor Soethe, Milton Camargo Mota. São Paulo: Loyola, 2007.

HABERMAS, Jürgen. Faticidade e validade: uma introdução à teoria discursiva do direito e do Estado democrático de Direito. Trad. Menelick de Carvalho Netto, no prelo.

HART, H. L. A. The concept of law. Oxford: Oxford University Press, 1961.

HART, H. L. A. La demystication du droit. In GÉRARD, Philippe, OST, François e KERCHOVE, Michel van de. Actualité de la pensée juridique de Jeremy Bentham. Bruxelas: Facultés Universitaires Saint-Louis, 1987, p. 89-118.

ISSALYS, Pierre. Vers la systématisation des lois québécoises. Les cahiers du droit, v. 21, n. 3 e 4,1980 , p. 523-565.

JEAN, Jean-Paul. Le systéme pénal. Paris: La Découverte, 2008.

JEAMMAUD, Antonie. En torno al problema de la efectividad del derecho. Crítica jurídica, n. 1, 1984, p. 5-15.

JESTAZ, Philippe e JAMIN, Christophe. La doctrine. Paris: Dalloz, 2004.

JIMÉNEZ DE ASÚA, Luis. Tratado de derecho penal, tomos I e II. Buenos Aires: Losada, 1950.

KALINOWSKI, Georges. Querelle de la science normative. Paris: Librairie Générale de Droit et de Jurisprudence, 1969.

KARPEN, Ulrich. Avaliação legislativa - a experiência alemã. Legislação: Cadernos de Ciência da Legislação, n. 33/34, jan.-jun. 2003, p. 9-14.

KELSEN, Hans. O que é justiça? São Paulo: Martins Fontes, 1997.

KELSEN, Hans. Teoria Pura do Direito. $4^{\mathrm{a}}$ ed. Trad. João Baptista Machado. São Paulo: Martins Fontes, 1994.

LASCOUMES, Pierre. La place du pénal dans le règlement différentiel des conflits. L’Année sociologique, 35, 1985, p. 153-165. 
LASCOUMES, Pierre e SERVERIN, Évelyne. Le droit comme activité sociale: por une approche wébérienne des activités juridiques. Droit et Societé, 9, 1988, p. 171-193.

LASCOUMES, Pierre. Normes juridiques et mise em oeuvre des politiques publiques. L'année sociologique, 40, 1990, p. 43-71.

LASCOUMES, Pierre. Pluralité d'acteurs, pluralité d'actions dans la création contemporaine des lois. In Acteur social et délinquance. Une grille de lecture du système de justice pénale. Liege: Pierre Mardaga, 1990, p. 145-163.

LAZERGES, Christine. Introduction a la politique criminelle. Paris: L'Harmattan, 2000.

LAZERGERS, Christine. Les conflits de politique criminelle. Archives de Politique Criminelle, n. 7, 1984, p. 38-48.

LE MAY, Denis. Pour un manuel de légistique, Les cahiers du droit, v. 21, n. 3 e 4, 1980, p. 993-1007.

LEAL, Victor Nunes. Problemas de direito público. Rio de Janeiro: Forense, 1960.

LENOBLE, Jacques e OST, François. Droit, mythe et raison. Essai sur la dérive mitologique de la rationalité juridique. Bruxelles: Facultés universitaires Saint-Louis, 1980.

LEVASSEUR, Georges. Politica Criminal y Derecho Penal. Revue Internationale de Droit Pénal, n. 1, 1978, p. 155-169.

LEVASSEUR, Georges. La politique criminelle. Archives de philosophie du droit, n. 16, 1971, p. 131-150.

MACHADO, Maíra Rocha; PIRES, Álvaro Penna; MATSUDA, Fernanda Emy; FERREIRA, Carolina Cutrupi e LUZ, Yuri Corrêa. Atividade legislativa e obstáculos à inovação em matéria penal no Brasil. Série Pensando o Direito. Brasília, Ministério da Justiça, 2010.

MACHADO, Marta Rodriguez de Assis. Sociedade do risco e Direito Penal: uma avaliação de novas tendências político-criminais. São Paulo: IBCCRIM (Monografias/34), 2005.

MADER, Luzius. Avaliação prospectiva e análise de impacto legislativo: tornam as leis melhores? Legislação: Cadernos de Ciência da Legislação, n. 42/43, jan.-jun. 2006, p. 177- 191.

MADER, Luzius. Avaliação dos efeitos da legislação - a situação actual na Suíça. Legislação: Cadernos de Ciência da Legislação, n. 33/34, jan.- jun. 2003, p. 135-155.

MADER, Luzius. Legislação e Jurisprudência. Cadernos da Escola do Legislativo, Belo Horizonte, v. 9, n. 14, jan.-dez. 2007, p. 103-206.

MADER, Luzius. L'évaluation législative. Pour une analyse empirique des effets de la législation. Payot Lausanne, 1985. 
MATHIEU, Bertrand. La loi. $3^{\text {a }}$ ed. Paris: Dalloz, 2010.

MARTINS, Argemiro e OLIVEIRA, Cláudio de. A contribuição de Klaus Günther ao debate. Revista Direito GV3, v. 2, n.1, jan.-jun. 2006, p. 241-254.

MAUS, Ingeborg. Judiciário como superego da sociedade. Novos Estudos, n. 58, nov. 2000, p. 183-202.

MELKEVIK, Bjarne. Habermas et l'Étata de droit. In L'amour des lois: la crise de la loi moderne dans les sociétés démocratiques. Québec: Université Laval e Paris: L'Harmattan, 1996, p. 371-387.

MENDES, Gilmar Ferreira e FORSTER JÚNIOR, Nestor José. Manual de redação da Presidência da República. $2^{\mathrm{a}}$ ed. rev. e atual. Brasília: Presidência da República, 2002, disponível em_https://www.planalto.gov.br/ccivil 03/manual/index.htm, acesso em 11.11.2010.

MINHOTO, Laurindo Dias. Privatização de presídios e criminalidade. A gestão da violência no capitalismo global. São Paulo: Max Limonad, 2000.

MORAIS, Carlos da Costa. Sistema de avaliação do impacto das normas jurídicas. Legislação: Cadernos de Ciência da Legislação, n. 32, out.-dez. 2002, p. 39-55.

MORAND, Charles-Albert. Formes e fonctions d l'évaluation législative. In OST, François e JADOT, Benoît (dir.). Élaborer la loi aujourd'hui, mission impossible? Bruxelles: Facultés Universitaires Saint-Louis, 1999, p. 207-227.

MORAND, Charles-Albert. Le droit néo-moderne des politiques publiques. Paris: L.G.D.J., 1999.

MORAND, Charles-Albert. Les exigences de la méthode législative et du droit constitutionnel portant sur la formation de la législation. Droit et Société, 10, 1988, p. 407423.

MORAND, Charles-Albert. L'évaluation législative ou l'irrésistible ascension d'un quatrième pouvoir. Revue de la recherche juridique, n. 4, 1994, p. 1141-1161.

MORENO HERNÁNDEZ, Moisés. La política criminal legislativa. In MORENO HERNÁNDEZ, Moisés (coord.). Orientaciones de la politica criminal legislativa. México: Inacipe, 2005, p. 131-167.

MOUFFE, Chantal. Penser la démocratie moderne avec, et contre, Carl Schmitt. Revue Française de Science Politique, v. 42, n. 1, 1992, p. 83-96.

NEVES, Antonio Castanheira. A redução política do pensamento metodológico-jurídico. Boletim da Faculdade de Direito da Universidade de Coimbra, edição especial de homenagem ao prof. Doutor Afonso Rodrigues Queiró, 1993, p. 393-447. 
NOBRE, Marcos. Apontamentos sobre a pesquisa em direito no Brasil. Cadernos Direito $G V$, n. 1, setembro 2004.

OST, François. Codification et temporalité dans le pensée de J. Bentham. In GÉRARD, Philippe, OST, François e KERCHOVE, Michel van de. Actualité de la pensée juridique de Jeremy Bentham. Bruxelas: Facultés Universitaires Saint-Louis, 1987, p. 163-230.

OST, François e JADOT, Benoît. Introduction générale. In OST, François e JADOT, Benoît (dir.). Élaborer la loi aujourd'hui, mission impossible? Bruxelles: Facultés Universitaires Saint-Louis, 1999, p. 7-10.

OST, François. La régulation: des horloges et des nuages. In OST, François e JADOT, Benoît (dir.). Élaborer la loi aujourd'hui, mission impossible? Bruxelles: Facultés Universitaires Saint-Louis, 1999, p. 11-34.

OST, François. L'interprétation logique et systématique et le postulat de rationalité du législateur. In KERCHOVE, Michel van de (dir.). L'interpretation em droit. Approche pluridisciplianire. Bruxelles: Facultés Universitaires Saint-Louis, 1978, p. 97-184.

OST, François e KERCHOVE, Michel van de. Jalons pour une theorie critique du droit. Bruxelles: Facultés Universitaires Saint-Louis, 1987.

PAIVA, Luiz Guilherme Mendes de. A fábrica de penas. Racionalidade legislativa e a lei de crimes hediondos. Rio de Janeiro: Revan, 2009.

PAULA, Felipe de. Processo legislativo, doutrina e academia: hipóteses de afastamento e efeitos deletérios. Fórum administrativo, v. 10, n. 116, out. 2010, p. 67-76.

PEDRON, Flávio Quinaud. A distinção entre jurisdição e legislação no pensamento de Klaus Günther. Revista CEJ, ano XII, n. 41, abr.-jun. 2008, p. 59-66.

PERROCHEAU, Vanessa. L'éxpérimentation, un nouveau mode de création législative. Revue française des affaires sociales, ano 54, n. 1, jan.-mar. 2000, p. 11-27.

PIRES, Álvaro. La rationalité pénale moderne, la societé du risque et la juridicisation de l'opinion publique. Sociologie et Sociétés, v. XXXIII.1, p. 179-204.

PIRES, Álvaro. A racionalidade penal moderna, o público e os direitos humanos. Novos Estudos CEBRAP, n. 68, março 2004, p. 39-60.

PONCELA, Pierrette. La vérité est de ce monde. Actes, 54, 1986, p. 69-72.

PONCELA, Pierrete et LASCOUMES, Pierre. Réformer le Code pénal. Oú est passé l'architecte? Paris: PUF, 1998.

POSSAS, Mariana Thorstensen. Systéme d'idées et création de lois criminelles : le cas de la loi contre la torture au Brésil. Thèse de Doctorat à 1'Université d'Ottawa, Canadá, 2009.

RELATÓRIO MANDELKERN. Legislação: Cadernos de Ciência da Legislação, n. 29, out.-dez. 2000. 
RIPERT, Georges. Les forces créatrices du droit. Paris: Librairie Générale de Droit et de Jurisprudence, 1955.

RIZEK JR., Rubens Naman. O processo de consolidação e organização legislativa. Tese de Doutorado, Faculdade de Direito da Universidade de São Paulo, 2009.

ROBERT, Philippe. Essai de construction d'un paradigme penal. In ROBERT, Philippe et al. Normes, normes juridiques, normes penales. Pour une sociologie de frontières, tomo II. Paris: L'Harmattan, 2000, p. 45-76.

ROBERT, Philippe. Sociologia do crime. Trad. Luis Alberto Salton Peretti. Petrópolis e Rio de Janeiro: Vozes, 2007.

ROBERT, Philippe. Sociologie et creation de la loi penal. In ROBERT, Philippe. La création de la loi et ses acteurs. L'exemple du droit pénal. Oñati Proceedings, 3, 1991, p. 207-215.

ROCHA, Jean-Paul Veiga da. A capacidade normativa de conjuntura no direito econômico: o déficit democrático da regulação financeira. Tese de Doutorado, Faculdade de Direito da Universidade de São Paulo, 2004.

ROCHA, Jean-Paul Veiga da. Separação dos poderes e democracia deliberativa. In NOBRE, Marcos e TERRA, Ricardo (orgs.). Direito e democracia. Um guia de leitura de Habermas. São Paulo: Malheiros, 2008, p. 173-197.

ROSANVALLON, Pierre. La légitimité démocratique. Impartialité, réflexivité, proximité. Paris: Seuil, 2008.

ROXIN, Claus. Politica criminale e sistema del diritto penale. Trad. Sergio Moccia. In ROXIN, Claus. Politica criminale e sistema del diritto penale. Saggi di teoria del reato. Napoli: Edizioni Scientifiche italiane, p. 37-79.

SALINAS, Natasha Schmitt Caccia. Avaliação legislativa no Brasil: um estudo de caso sobre as normas de controle das transferências voluntárias de recursos públicos para entidades do terceiro setor. Dissertação de Mestrado. Universidade de São Paulo, 2008.

SÉNAT. L'evaluation de la legislation. Les documents de travail du Sénat, série Législation Comparée, octobre 1995.

SILVA, José Afonso da. Processo constitucional de formação das leis. $2^{\mathrm{a}}$ ed. $2^{\mathrm{a}}$ tir. São Paulo: Malheiros, 2007.

SILVA, Lívia Matias de Souza. Devido processo legislativo: um olhar sobre a Assembléia Legislativa do Estado de Minas Gerais. Cadernos da Escola do Legislativo, Belo Horizonte, v. 10, n. 15, jan.-dez. 2008, p. 43-82.

SOARES, Fabiana de Menezes. Legística e desenvolvimento: a qualidade da lei no quadro da otimização de uma melhor legislação. Cadernos da Escola do Legislativo, Belo Horizonte, v. 9, n. 14, jan.-dez. 2007, p. 7-34. 
SOARES, Mauro e WERLE, Denílson. Política e direito: a questão da legitimidade do poder político no Estado democrático de direito. In NOBRE, Marcos e TERRA, Ricardo (orgs.). Direito e democracia. Um guia de leitura de Habermas. São Paulo: Malheiros, 2008, p. 117-145.

SPARER, Michel. Avant-propos. Les cahiers du droit, v. 21, n. 3 e 4, 1980, p. 507-509.

SPARER, Michel e SCHWAB, Wallace. Rédaction des lois: rendez-vous du droit et de la culture. Québec: Conseil de la langue française, 1980.

SZABO, Denis. Criminologie e politique criminelle. Paris: Librairie Philosophique J. VRIN e Montréal: Université de Montréal, 1978.

TERRÉ, François. La « crise de la loi ». Archives de philosophie du droit, tome 25, 1980, p. 17-28.

VERBICARO, Loiane Prado. Um estudo sobre as condições facilitadoras da judicialização da política no Brasil. Revista Direito GV 8, v. 4, n. 2, jul.-dez. 2008, p. 389-406.

VIANDIER, Alain. La crise de la technique législative. Droits. Revue française de théorie juridique, 4, 1986, p. 75-80.

VILHENA, Oscar Vieira. Supremocracia. Revista Direito GV 8, v. 4, n. 2, jul.-dez. 2008, p. 441-464.

VILLEGAS, Mauricio García. La eficacia simbólica del derecho. Santafé de Bogotá: Uniandes, 1993.

VILLEY, Michel. Préface. Archives de Philosophie du Droit, tome 23, 1978, p. 1-10.

ZAFFARONI, Eugenio Raúl e PIERANGELI, José Henrique. Manual de direito penal brasileiro. Parte geral. $3^{\text {a }}$ ed. São Paulo: Revista dos Tribunais, 2001.

ZIEMBINSKI, Zygmunt. La notion de rationalité du législateur. Archives de philosophie du droit, tome 23, 1978, p. 175-187.

ZIPF, Heinz. Introducción a la política criminal. Trad. Miguel Izquierdo Macías-Picavea. Caracas: Editoriales de Derecho Reunidas, 1979. 


\section{DOCUMENTOS E PÁGINAS NA INTERNET}

Congresso Internacional de Legística: qualidade da lei e desenvolvimento, 2007, http://www.almg.gov.br/index.asp?grupo $=$ servicos\&diretorio $=$ publicacoes\&arquivo=legist ica, acesso em 23.11.2010.

Manual de redação de elaboração de textos do Senado Federal, 1999 (http://www.senado.gov.br/senado/conleg/manualdeelaboracaodetextos.pdf, acesso em 23.11.2010.

Manual de técnica legislativa do Senado Federal, 2002 (http://www.senado.gov.br/senado/conleg/tecnicalegislativa-2002.pdf, acesso em 23.11.2010.

Rapport «Projet de loi instituant une procédure d'évaluation législative », Sénat de Belgique, session de 1998-1999, disponível em http://www.senate.be/www/webdriver?MItabObj=pdf\&MIcolObj=pdf\&MInamObj=pdfid

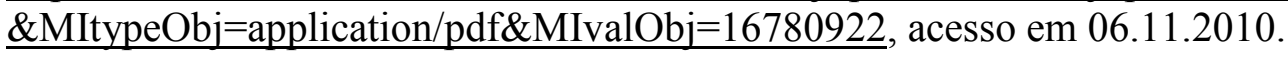

Relatório anual da Consultoria Legislativa do Senado Federal, 2007, (http://www.senado.gov.br/senado/conleg/artigos/Rel 2007.pdf, acesso em 23.11.2010.

Regulatory impact analysis: best practices in OCDE countries, 1997, disponível em http://www.oecd.org/dataoecd/21/59/35258828.pdf, acesso em 12.11.2010.

Seminário A consolidação das leis e o aperfeiçoamento da democracia, 2002, http://www.almg.gov.br/index.asp?grupo $=$ servicos\&diretorio $=$ publicacoes\&arquivo $=$ conso lidacaoleis, acesso em 23.11.2010.

The OECD reference checklist for regulatory decision-making, 1995, disponível em http://www.oecd.org/officialdocuments/displaydocumentpdf?cote=OCDE/GD\%2895\%299 $\underline{5 \& \text { doclanguage }=\text { en, }}$ acesso em 11.11.2010.

The 1997 OECD Report to Ministers, disponível em http://www.oecd.org/dataoecd/17/25/2391768.pdf, acesso em 23.11.2010.

The 2005 OECD Guiding principles for regulatory quality and performance, disponível em http://www.oecd.org/dataoecd/24/6/34976533.pdf, acesso em 23.11.2010.

The 2005 APEC-OECD Integrated checklist on regulatory reform, disponível em http://www.oecd.org/dataoecd/41/9/34989455.pdf, acesso em 23.11.2010.

http://www.archives.gov/federal-register/codification/executive-order/12291.html, acesso em 11.11.2010.

http://www.cabinetoffice.gov.uk/making-legislation-guide/impact_assessment.aspx, acesso em 11.11.2010.

http://www2.camara.gov.br/a-camara/estruturaadm/conle, acesso em 23.11.2010. 
http://www.csl.gov.pt/, acesso em 12.11.2010.

http://www.cultura.gov.br/consultadireitoautoral/, acesso em 19.12.2010.

http://culturadigital.br/classind/, acesso em 19.12.2010.

http://culturadigital.br/dadospessoais/, acesso em 19.12.2010.

http://culturadigital.br/marcocivil/, acesso em 23.11.2010.

http://ec.europa.eu/governance/impact/index en.htm, acesso em 11.11.2010.

http://ec.europa.eu/governance/better_regulation/index_en.htm, acesso em 11.11.2010.

http://www.edemocracia.camara.gov.br/publico/, acesso em 19.12.2010.

http://www.interlegis.gov.br/, acesso em 23.11.2010.

http://portal.mj.gov.br/conportos/main.asp?View=\{329D6EB2-8AB0-4606-B054-

4CAD3C53EE73\}, acesso em 23.11.2010.

http://projeto.lexml.gov.br/, acesso em 23.11.2010.

http://www.regulacao.gov.br/, acesso em 19.12.2010.

http://www.senado.gov.br/senado/conleg/insti_consultores.htm, acesso em 23.11.2010.

http://www.senado.gov.br/senado/conleg/institucional.htm, acesso em 23.11.2010.

http://www.senat.fr/commission/legislation/index.html, acesso em 06.11.2010.

www.stf.gov.br, acesso em 17.08.2010.

http://virtualbib.fgv.br/dspace/bitstream/handle/10438/7719/coment\%C3\%A1rios\%20ao\% 20substitutivo\%20PL\%2088-99.pdf?sequence=1, acesso em 23.11.2010.

http://www.whitehouse.gov/sites/default/files/omb/inforeg/eo12866.pdf, acesso em 11.11.2010.

http://www.whitehouse.gov/omb/inforeg default, acesso em 11.11.2010. 